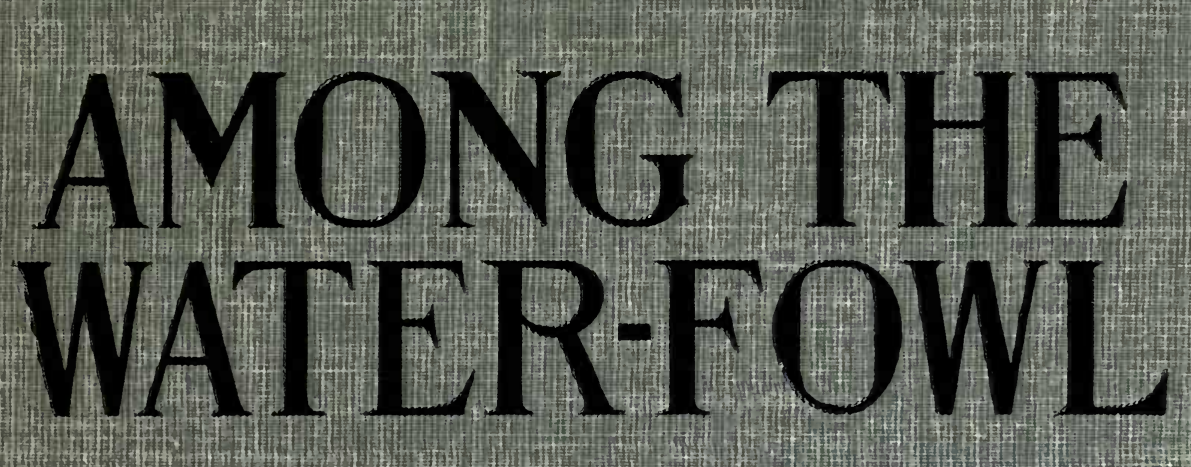

UC-NRLF

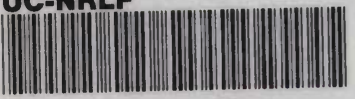

B 3301,181

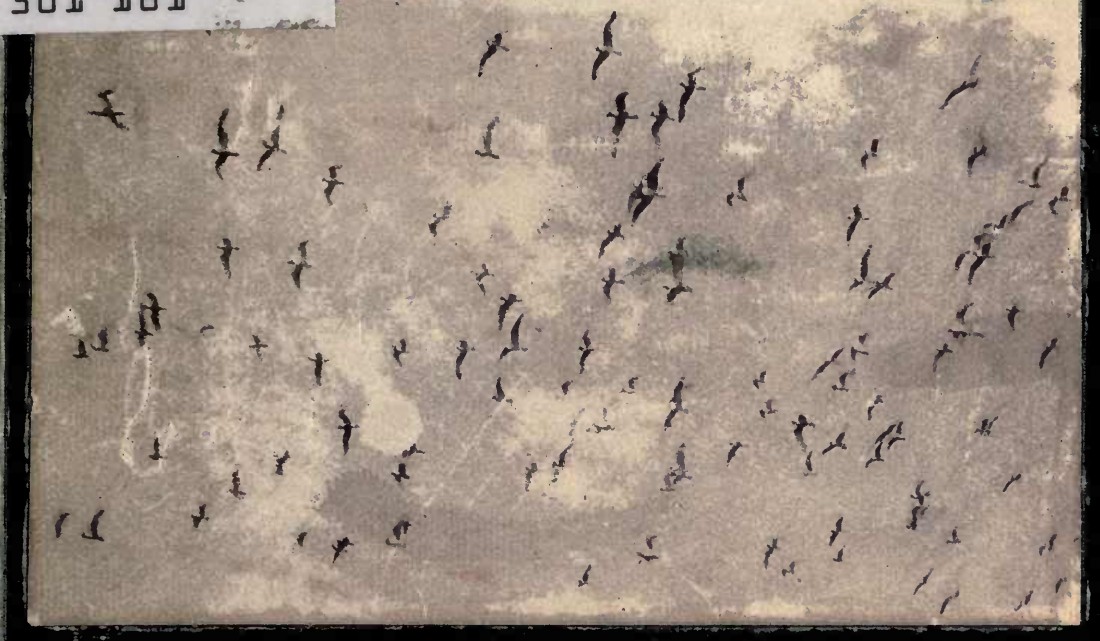

HERBERT K. JOB 


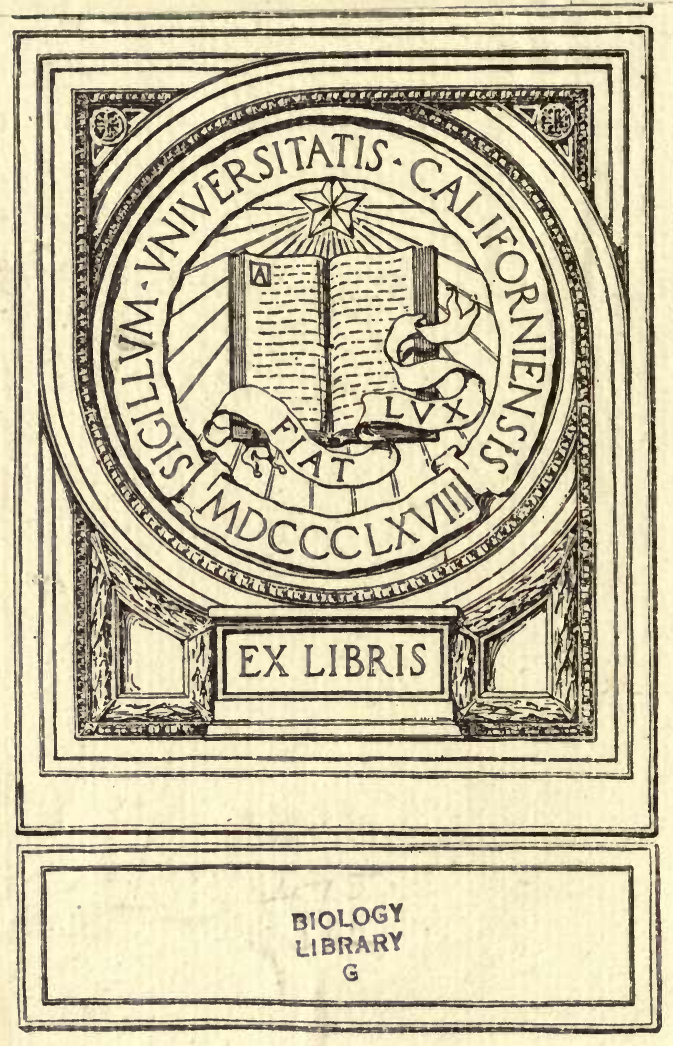




AMONG THE WATER-FOWL 




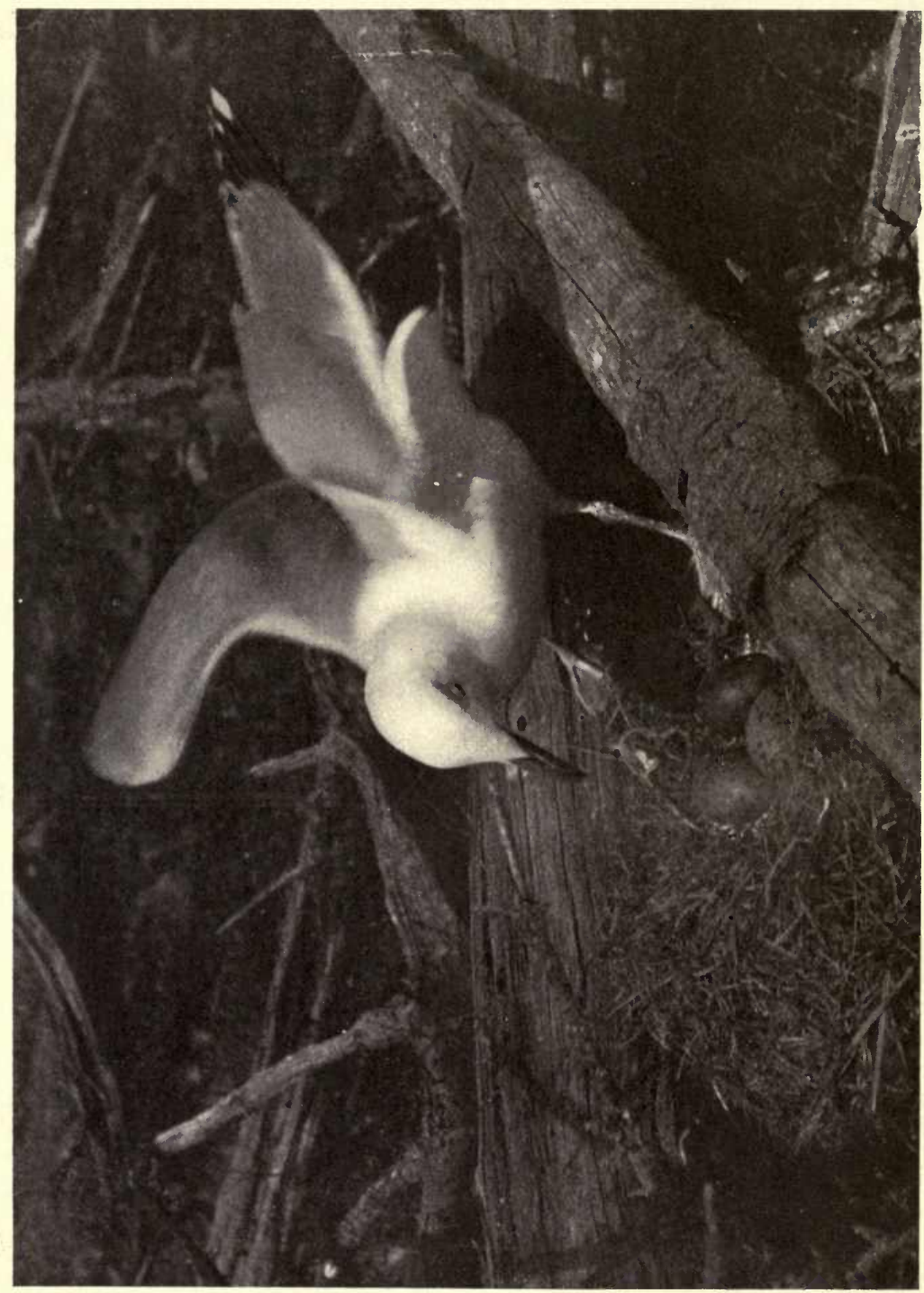

窟

渵

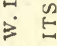

ते

ถู

है

हैं

沗

II

3

?

3

?

范

a

$x$

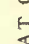

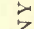

9

8

至

5

I

2

논

근

吉

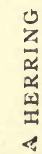




\title{
AMONG THE WATER-
} FOWL OBSERVATION, ADVENTURE, PHOTOGRAPHY. A POPULAR NARRATIVE ACCOUNT OF THE WATER-FOWL AS FOUND IN THE NORTHERN AND MIDDLE STATES AND LOWER CANADA, EAST OF THE ROCKY MOUNTAINS

\author{
by \\ HERBERT K. JOB
}

PROFUSELY ILLUSTRATED BY PHOTOGRAPHS FROM NATURE, MOSTLY BY THE AUTHOR

NEW YORK

DOUBLEDAY, PAGE \& CO. 1903 


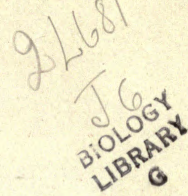

Copyright, 1902, by JoHN W ANAMAKER

Copyright, 1902, ky Doubleday, Page \& Ćo.

Published May, rgoz

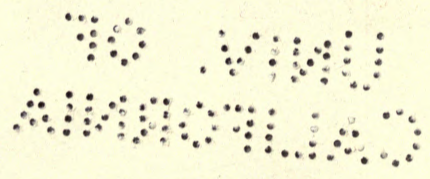




\begin{abstract}
TO MY WIFE
WHO FIRST INVEIGLED ME INTO USING THE CAMERA THIS VOLUME IS AFFECTIONATELY DEDICATED
\end{abstract}





\section{PREFACE}

IT was the beautiful bird-pictures of Audubon that fascinated me as a child and made me love the birds and begin to watch them, such as could be found in the home garden in the suburbs of Boston. By the time that I was old enough to be trusted afield, the limits of the city became too narrow, and I began to roam abroad, seeking out the haunts of the birds. In due time I had formed a considerable acquaintance with all the familiar songsters, and many others. Soon I came to feel a special interest in the shyer and more mysterious species that the average youngster knew nothing of. The Hawks and Owls were my especial delight, and to discover their nests no amount of effort was too great a price to pay.

This enthusiasm soon took me to the sea-coast, where there were new worlds to conquer in the hordes of migratory Waders and strong-winged fowl of the deep, about which the books were all too silent. Audubon knew them best, but my other favourite writers seemed to have sadly neglested them. Samuels' “ Birds of New England" I almost knew by heart, but many of my bird-favourites its author was evidently little acquainted with. Minot was intensely interesting, but he stopped short of the Water-Fowl.

In pursuit of these inhabitants of shore and ocean, various were the craft that I owned and navi- 
gated, and many the narrow escapes. However, I am yet alive, and the Wild-Fowl have thought it best, in view of my persistency, to take me in some measure into their confidence and divulge to me some of their secrets. And now, after rounding out a full quarter-century of these pryings, on land and sea, I hope that I am not abusing the confidence of my wild friends in telling what they have taught me. The Robins and Chippies, with their kin, have been popularized in books innumerable; but why should not the great Nature-loving public find also interesting and instructive the lives and ways of the Water-Fowl? In time past these have been thought of largely as targets for the gun. Perhaps they will pardon me for laying bare-their lives to scrutiny, as I protest to them, upon the first occasion of our future meeting, that I am trying to raise up friends for them, not foes. It will mark a new era in our civilization when the now persecuted Wild-Fowl can alight in the village pond and feed in peace, the object only of friendly admiration.

As yet they are fearful of that new, mysterious Cyclops with its staring eye, the camera; but I hope they may learn to recognize in it a real friend, for in thousands of hands this is taking the place of the gun. Far be it from me to deny that there are legitimate uses for the dead bird. But owing to relentless, short-sighted slaughter, hitherto carried on, it is coming to be a question of birds or no birds. Every true sportsman will practise great moderation in the capture of game, and every thoughtful lover of wild life stand for its protection. Exercise afield and contact with Nature are invaluable, 
but require an incentive. If the destruction of life can be minimized by the finding of some satisfactory substitute for the gun, no one will be the loser.

Such a substitute I myself have found in the camera, which fully satisfies my hunter's instinct. Far more skill and resource are required to photograph a wild creature than to shoot it, and the picture, when secured, is, ordinarily, of far greater value than a few mouthfuls of flesh. As I recall successful shots at fowl from the gunning-stand, I would give much to have the pictures now to enthuse me, in exchange for fleeting memory. Would it not be wise policy to interest our boys in Naturestudy, and the camera as applied to it, and discourage shooting at living things? Real acquaintance with a harmless and beautiful wild creature, I can testify, makes one less and less disposed to take its life.

Hence I would most cordially commend to my fellow sportsmen and bird-lovers this noble instrument. An expensive outfit is entirely unnecessary. In case my own experience may be of any encouragement, let me say that all my pictures in this book were taken with an ordinary 4 by 5 focusing camera, rapid rectilinear lens, and bellows of i 2 inches draw, that cost me less than \$20. I consider the 4 by 5 size just right for field work. Equipped with such a camera and any good make of rapid plates, with a little careful study and practice of photographic method, following out some such plans afield as are described in this and other volumes, joined with real love for the birds and Nature, there is no reason why anyone may not succeed better 
than I have done. I only hope that my work may help extend the growing enthusiasm for Naturestudy, and that the simple narrative of my personal observations, written without any assumption of technical learning, may interest many in my friends, the Water-Fowl.

Though my experiences, as narrated, have been largely in the northern portions of the country, they characterize almost equally well the Water-Fowl of the middle districts, and the species mentioned, wherever found. Owing to exigencies of space, many of the illustrations are reduced in size from the original photographs; where there has been appreciable enlargement, the fact and degree are noted.

Companions in the field and other friends have generously placed at my disposal even more of their pictures than could be used, supplying certain gaps in my material, and I wish herewith to express my grateful acknowledgments to Messrs. A. C. Bent, C. S. Day, Owen Durfee, Rev. C. J. Young, W. L. Baily, W. H. Fisher and H. A. Shaw.

Herbert K. Јob.

Kent, Connecticut, March, 1902. 


\section{TABLE OF CONTENTS}

\section{PART I.-The Submerged Tenth}

Grebes and Loons

PAGES

Among Colonies of the American Eared Grebe . . . . I-I4

The Great City of the Western Grebe . . . . . 15-27

Holboell's, Horned and Pied-billed Grebes • • . 27-33

Grebes Breeding in the East ; their habits in autumn and winter $33-39$

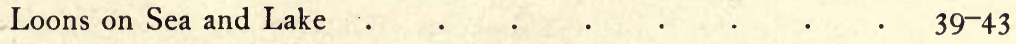

The Breeding-haunts of the Loons . . . . . . $43-49$

\section{PART II.-MODERN ClIFF-DWELlerS}

Gannets, Guillemots, Auks, Puffins, Kittiwakes, etc.

Glimpses of the Magdalen Islands . . . . . $50^{-}-52$

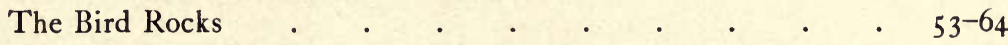

Second Day on Great Bird Rock . . . . . $64-73$

Third Day, and the Trip to North Bird Rock . . . . $73^{-80}$

Last Observations on the Rock . . . . . . 8 $8 \mathrm{I}-83$

Further Researches on Other Islands of the Magdalen Group $\quad 83-86$

Other Cliff-Dwellers Breeding on the Coast of Maine . . 86-9o

After the Breeding Season; winter along the coast . . . $9 \mathbf{I}^{-96}$

\section{PART III.-OCEAN WANDERERS}

Shearwaters, Jægers or Skuas, Petrels, Phalaropes

Summer Ocean Birds off Cape Cod . . . . . . 97-107

Photographing the Ocean Wanderers . . . . . 107-114 
The Nesting of the Ocean Wanderers; visits to the breedinggrounds of Leach's Petrel.

\section{PART IV.-The White-Winged Fleet}

Gulls and Terns

Visits to Herring Gull Islands along the Atlantic Coast . . 130-139

Tern Colonies and Habits in the East . . . . 139-144

Other Gulls on the Eastern Coasts . . . . . . 144-146

The "Enchanted Isles," North Dakota; colonies of Doublecrested Cormorants, Ring-billed Gulls and Common Terns 146-157

A Great Colony of the Franklin's Rosy Gull; breeding and other habits of the Black Tern; the American White Pelican . 157-169

\section{PART ,V.-WILD Fowl OF WILD FowL Ducks and Geese}

A Tour in North Dakota among Breeding Ducks and Geese . 170-189 Breeding of the Later Ducks on the Return Trip . . . 189-196 Tree-nesting Ducks in North Dakota . . . . . 196-200 Subsequent Trip to North Dakota, and Further Discoveries 201-206

The Breeding-Habits of Ducks in the East, from the Magdalen Islands to Southern New England . . . . . 206-213

Habits of the Wild-Fowl in Southern New England after the Nesting Season; gunning-stands and the fowl that visit the ponds - $213-218$

Sea-coast Fowl; habits, modes of capture, migrations . 218-224 


\section{LIST OF ILLUSTRATIONS.}

Franklin's Rosy Gulls in flight. Cover picture.

Herring Gull approaching nest $\left(\begin{array}{ll}\mathrm{x}_{2}\end{array}\right)$. . . Frontispiece

Mounted Loons and Grebes . . . . . . . 2

American Eared Grebe Colony . . . . . . 7

Other nests of the Eared Grebes . . . . . . 10

Franklin's Rosy Gull eating Eared Grebe's Eggs . • . 14

Eared Grebe's by their nests . . . . . . . 16

Nest of Western Grebe . • • • • • • • ${ }^{1} 7$

A Western Grebe-colony scene . . . . . . 19

A Western Grebe . . . . . . . . . 20

A group of Eared Grebes $\left(x+\frac{1}{2}\right)$. . . . . 22

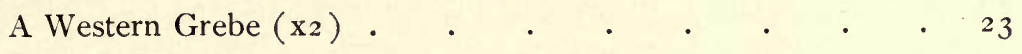

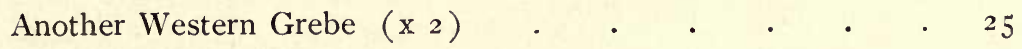

Still another Western Grebe $\left(\mathrm{x}_{3}\right)$. . . . 26

Nest of Holboell's Grebe . . . . . . . 28

Nest of Pied-billed Grebe, or Dabchick . . . . . 30

Covered nest of the Dabchick . . . . . . . 3 I

Nest and young of Horned Grebe . . . . . . 34

Nest and eggs of Horned Grebe . . . . • • 35

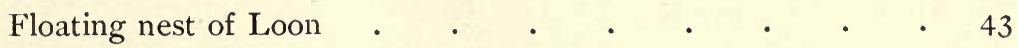

Nest of Loon on stony shore .

Site of preceding Loon's nest . . . . . . . ${ }_{46}$

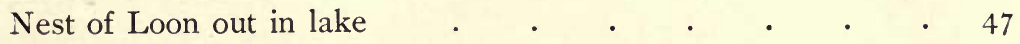

Another view of preceding . . . . . . . 48

View of Great Bird Rock . . . . . . . 50

Murres and Kittiwakes from the crate . . . - . 54

The city of the birds . . . . . . . ${ }_{56}^{6}$

View of North Bird Rock from top of Great Bird Rock • • 57 xiii 
Another cliff view . . . . . . . . . $\quad 5^{8}$

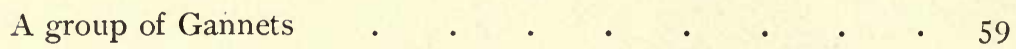

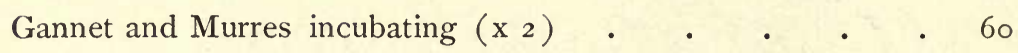

Nesting-site of Razor-billed Auk . . . . . . 6 6

Eggs of Murres as laid on ledge . . . . . . 62

A Gannet colony . . . . . . . . $\quad$. 63

A Puffin sitting for his portrait $\left(\mathrm{x}_{4}\right)$. . . . . 67

Another Puffin portrait ( $\left.x_{4}\right)$. . . . . . . 68

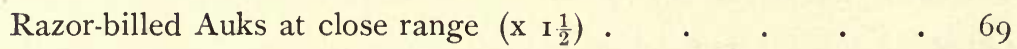

Group of Murres, Puffins and Razor-billed Auk . . . 70

The Pillar, or Pinnacle, North Bird Rock • • • • 74

Nest of Gannet, North Bird Rock . . . . . 75

An incubating Brünnich's Murre . . . . . . 77

Common Murres on their eggs ( $x_{3}$ ) . - . . 78

Kittiwakes nesting $\left(\mathrm{x} \times \frac{1}{2}\right)$. . . . . . . 79

Gannets, Murres and Kittiwakes on the lower ledges . . 80

The home of the Ocean Wanderers . . . . 97

A pair of Greater Shearwaters . . - . . . 108

Two Greater Shearwaters close to vessel . . . . 109

The Greater Shearwaters, a hungry horde . . . . I I I

Wilson's Petrels, or "Mother Carey's Chicken's" . . . I I4

Sooty and Greater Shearwaters . . . . . . II6

Wing-study of Western Gull . . . . . . . I 3 I

Western Gulls in Flight . . . . . . . . . 133

Another study of Western Gulls . . . . . • 135

Herring Gulls alighting on trees . . . . . . 137

Nest of Herring Gull . . . . . . . . 138

Slovenly nest of Common Tern . . . . . . $\quad$ I 42

Well-built nest of Common Tern . . . . . . 143

Nest of Least Tern . . . . . . . . . 144

Nest of Ring-billed Gull . . . . . . . . $\quad$. 148

Nests of Double-crested Cormorants . . . . . 149 
Ring-billed Gulls by their nests

PAGE

Ring-billed Gull incubating

Ring-billed Gulls on Rocks

Young Common Tern .

Common Tern coming to her eggs

The same Tern incubating

Young Ring-billed Gull .

Franklin's Rosy Gull colony

Nest of Franklin's Gull

Pair of Franklin's Gulls on their nest

Scene in Franklin's Gull colony

Franklin's Gull and chick

Nest of Black Tern

Typical Dakota slough

Nest of Canvasback

Nest of Canada Goose

A Mallard drake

Nest of Mallard drake

Nest of Redhead .

Another view of Mallard drake

Nesting-site of Canvasback

Nest of Lesser Scaup Duck

Nest of White-winged Scoter .

A Scoter detained by her nest

Nesting-site of American Golden-eye • • • • 197

Golden-eye's nest in stub

Young Shovelers in their nest

- 198

Nest of Ruddy Duck . . , . . . . . 203

Nest of Redhead . . . . . . . . . . 204

The same nest, showing surroundings . . . . . 204

Nest of Canvasback with egg of Ruddy Duck . • . 205

A Magdalen Islands' morass where Ducks breed • • . 207 
Nest of Dusky Duck . . . . . . . . . 208

Nest of Greater Scaup Duck . . . . . 209

Nest of Blue-winged Teal . . . . . . 2 ro

Another nest of Dusky Duck . . . . . . 212

Live Duck-decoys, from a gunning stand . . . . 2 I6

Young Dusky Duck . . . . . . . . 224 


\section{INDEX}

PAGR

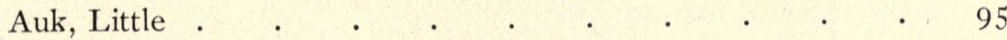

Razor-billed $\quad . \quad 51,53,55,59,6 x, 69,72,76,92,93,95$

Badger

Baldpate

Bittern, American

I 77, 189, 190, 193, 201, 2 I 5

Blue-bill, (See Scaup Duck)

Brant

$82, \quad 166$

Buffalo

Bufflehead

2 I 8,2 I9

Burgomaster, (See Glaucus Gull)

Canvasback . I 73, I76, I77, 186-188, г91, 196, 202-206 2 15

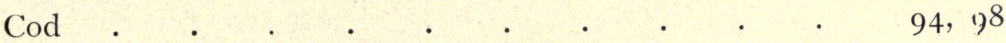

Coot, American . . . . 2, 6, I6 1, I66, I73, I7\%

Butter-billed . . . . . . . . 222

Gray . . . . . . . . . . . 222

Skunk-head . . . . . . . . . . 222

White-winged . $\quad . \quad . \quad . \quad \cdot \quad \cdot \quad \cdot 222$

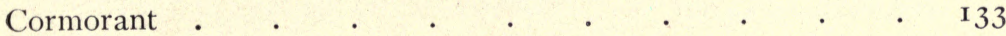

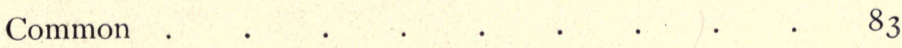

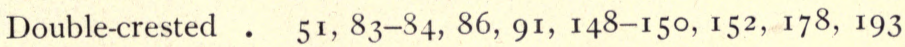

Coyote

Crane, Sandhill . $\quad . \quad . \quad . \quad . \quad . \quad . \quad . \quad I_{72}$

Crossbill, White-winged $\quad . \quad$. $\quad . \quad$. $\quad . \quad$. 82

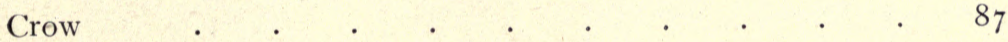

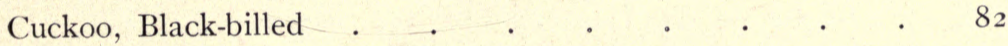

Dabchick, (See Pied-billed Grebe)

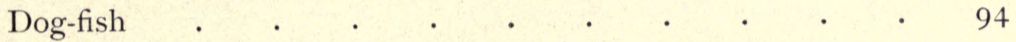

Dovekie, (See Little Auk)

Duck . . . . I $12,4,5,39,7$ I, I26, I66, I70-224

Black, (See Dusky)

Dusky . . . $\quad 207,208,2$ I $2-2$ I3, 2 I5, 223

Greater Scaup . $\quad \ldots \quad \ldots \quad$ I77, I9I, 207, 209, 217

xvii 
Duck, Harlequin

Lesser Scaup . . I77, I 89-193, 20I-202, 206, 2 I 7

Long-tailed, (See Oldsquaw)

Ring-necked Scaup .

Ruddy

Scaup

Sea, (See American Eider)

Sea Ducks

Eider, American .

Flicker

\section{King}

$$
7 \text { I, I9I, 2II, 218, } 221,223
$$

$$
\text { I86, I9 I, 201, 206, } 2 \text { I } 7
$$

I 7 7, 19I, I94, 196, 202-206, 2 I 5 208, 2 I0, 221,223

Gadwall

Gannet

Godwit, Great Marbled

Golden-eye, American Barrow's

$$
\text { - } 177-178,190,192-193,201-202,206,2 \text { I } 5
$$
$53,55-60,62-63,65,69,70,72-75,77,80,9^{2}$

Goosander, (See American Merganser)

Goose

Canada

Snowy

Gopher

Grackle, Bronzed

9I 170,2 I $7-2$ I 8,22 I

Grebe

American Eared

Holboell's

Horned

Pied-billed

Western 218 
Gull, Minister, (See Great Black-backed)

PAGE

Ring-billed . . . $\quad$ I45-I57, I62, I 77, I89, I9 I

Turkey, (See Great Black-backed)

Western

Haddock

Hag, or Haglet, (See Shearwater)

Hake

Hawk, Marsh

Red-tailed

Sparrow

Heron, Night

Jack Rabbit

Jaeger

Long-tailed

Parasitic

Pomarine,

Jiddy, or Jiddy-hawk, (See Jaeger)

Kingbird

$$
\begin{array}{rrr}
\cdot & \cdot & \text { I3 I, I33, г35 } \\
. & . & 94,9^{8}
\end{array}
$$

Kittiwake $\quad 53,55,59,65,7 \mathrm{I}-72,75-77,79,80,94$

Lark, Prairie Horned . . . . . . . . I

Longspur . . , . . . . . . . I

Loon . . . . . . . . . . . $39-49$

Red-throated, or Pegging-awl . . : . $4 \mathrm{I}-42$

The, or Great, or Great Northern . 2, 39-49

Mallard . I 7 I, I 77-I78, I8 I, I84-185, I9 1, I96, 206, 208, 2 I 5

Martin, Purple . $\quad . \quad$. $\quad . \quad$. . . 29

Meadowlark, Western . . . . . . . I

Merganser, American . . . . . . 2 Iо, 2 I8

Hooded . . . . 200, 206, 2 10, 2 I 8

Red-breasted . . . 207-208, 2 I0, 2 I9, 22 I, 223

Mink

27

Mother Carey's Chickens, (See Petrel)

Murre, $\quad 50,53,55,59,6$ I $, 62,65,69,72,76-77,80,86,92,94$

Brünnich's

$60,65,93,95-96$

Common . . . . . . . $65,78,95$

Ringed . . . . . . . . . . 66

Muskrat

Noddy, (See Murre) 
Old-squaw

Oriole

Osprey

Owl, Long-eared

Parrot, Sea, (See Puffin)

Pelican, White

I $68-169$

Petrel

Leach's

101-102, I04-I08, IIO, II3, I2I, I 34

Stormy

$64,72-73$, 101-102, 104-106, I 24-1 29

Wilson's

IO2

Phalarop

Northern

Red

IOI-IO2, 108, I I 4, II 7

Wilson's

Pigeon, Sea, (See Black Guillemot)

Pintail

. I 7 I, I 75-1 78, I 89, I9 I-193, 206, 2 I 5

Plover

Golden

84

Puffin

Rail

- 5 I, 53, 59, 60, 66-68, 72, 8 I, 89-9 I, 93, 95

Raven, Northern

166, 203

Redhead $\quad \mathrm{I} 77, \mathrm{I} 83, \mathrm{I} 85$, I87, I9 I, I96, 202-204, 206, 2 I I , 2 I 5

Robin

Sandpiper

Spotted

Sapsucker

I $20-123$

I $20-132$

I 20, I 22

I 20

Scoter

American, or Black

Surf

White-winged

Sea Goose, (See Phalarope)

Sea Hen, (See Jaeger)

Shearwater

Corey's

99-101, 105-106, I10, I I2-I 13, I 1 7, I 2 I

Greater

Sooty

10 $102-103$

99, Іо3, го8, I I 5-1 6

Shelldrake, or Sheidrake, or Shell-duck, (See Merganser)

Shoveller, or Shoveler I7 I, I77, I83, I85, I9I-192, 202, 206, 2 I5 
Skua, (See Jaeger)

Sparrow

Savanna . . . . . . . . .

Song $. \quad . \quad . \quad . \quad . \quad .30$

White-throated . , . . . . 30

Swallow, Barn . . . . 29, 127-128

Tree . . . . . . . . . 29

Swan

Teal

Blue-winged

I 68

Green-winged . . . . I72, I 88 , I9 I

Tern 65,84, I08, II 5-II 7, I30, I35, I40, :44-I 45

Arctic . . . . . . I39-I42

Black . . . . I, I6I, I66-I68

Common . I40. $142,{ }^{2} 53^{-1} 56,162,189,191,208$

Least . . . . . . . $143^{-144}$

Roseate . . . . . . . . . 143

Wilson's, (See Common)

Ting-tang, (See Holboell's Grebe)

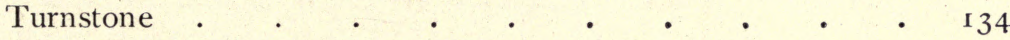

Yellowlegs . . . . . . . . . . .

Warbler, Mourning . $. \quad . \quad . \quad . \quad 30$

Water Witch, (See Grebe)

Whale, Fin-back • • • • • • • • • $9^{8}$

Whale-bird (See Phalarope) . . . . • . I 2 I

Whistler, (See Golden-eye)

Widgeon, American, (See Baldpate)

Willet . • . • . • • • • • • $\mathrm{I} 7 \mathrm{I}$

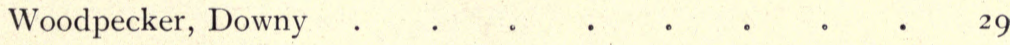

Wren, House . . . . • . . . 29 



\section{AMONG THE WATER-FOWL}

\section{THE SUBMERGED TENTH \\ (Grebes and Loons)}

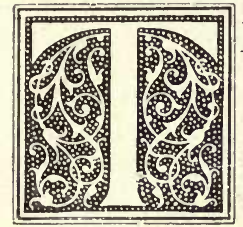

HE seventh day of a recent June found me, with a companion, driving over the sun-baked, fire-scorched prairie of North Dakota, within a few miles of the international boundary. For miles no settler's shack had been sighted to break the solitude. No pioneer had yet overturned the sod and sown his wheat, or erected the ugly barbed wire fence to compel travel "on section lines." Not even a wagon-trail offered its suggestion of a better way. We were free to consult the compass, and lay our course, as though at sea, over the virgin prairie, that had remained just as the Buffalo had left it. Though the scenery was monotonous, there was a certain fascination in jogging along over this billowy grass in the crisp, stimulating air, with the frequent glimpses of birds and animal life. Ducks flew out from the little wet depressions. A covey of cock Pinnated Grouse whirred away from a weedy spot. Meadowlarks, Longspurs, Sparrows or Prairie Horned Larks were nearly always in sight, with Black Terns flitting about. At any time we were liable to see a Coyote slinking off in the distance, a Badger dozing by its hole, or to start a JackRabbit and see it speed away with surprising leaps. Gophers scurried to their burrows, and disappeared with that comical little whisk of the tail that always forces me to an inward smile. 


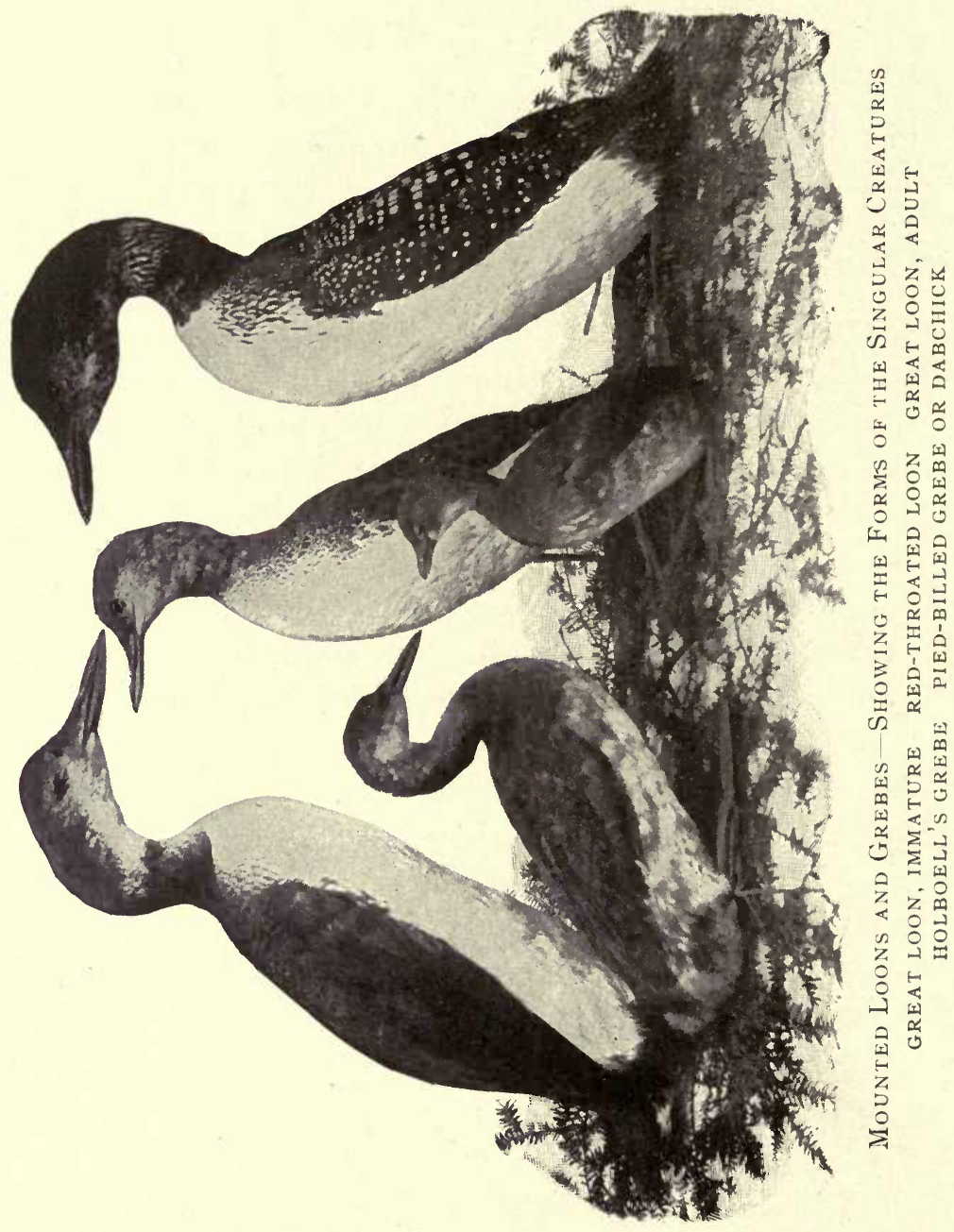


We were driving from our camp on the windswept plain by Rush Lake to a small lake, or "slough," some miles farther to the west, which a settler had told us swarmed with birds. At length it lay before us, a third of a mile of open water, with a large grassy island in the centre. Many Ducks, Coots and Grebes were in sight; but on the shore of the island were the most birds - a great flock fairly darkening the area.

Not being able to decide from that distance what they were, I resolved to wade out to them. Now Dakota "sloughs" - as marshy ponds are there called, pronounced "sloo"-are generally quite shallow; but a few steps into this one made it evident that boots here were of no avail. It was pretty cold to strip for the task, and the water felt like ice; but the prospect of getting out in the sun upon the shore of the island before coming back decided me in favour of the project and I started in. At every step difficulties increased. The water became breast deep, and was filled from bottom to surface with decaying vegetation. After every half dozen steps I had to stop and clear myself from the great island that had collected about me. For fifteen minutes I struggled on, chilled, but intent upon reaching the sunny island shore, where I could don the garment I held up out of the water, and examine at my leisure the many nests which I expected to find.

As I came to the edge of an area of long grass that had hidden from me what was beyond, a wonderful sight met my eyes. The water seemed literally alive with birds, swimming or floating upon its 
surface. Sprinkled about everywhere among them were what looked like little mounds. Upon nearly every mound sat a bird. As they saw me, some slid off into the water, while others industriously pecked at something. Then it dawned upon me-I had found a breeding colony of the American Eared Grebe. The mounds were nests, and the birds were covering their eggs, as is their custom, to hide them from the intruder.

Soon I was right in the midst of the Grebe city. But such wet, untidy, uncomfortable homes they were, as contrasted with the warm, soft, downy beds that Ducks prepare, the substantial structure of the Robin, or the elaborately-woven pouch of the Oriole! I felt that I was in the slums of bird-dom. Here was the problem of the submerged class of their society. But who, after all, would be the happier should the Grebe ascend from the bottom round of the ladder of classification, and, forsaking his fish relations and his habits of submergence, make a cleaner nest ashore, and waddle awkwardly on dry land?

At my approach the Grebes all left their nests, though in some cases the anxious owners lingered to cover their treasures until I was almost upon them. This enabled me to watch carefully the whole process. The bird arose from a prostrate position upon the eggs, and assumed one more or less upright, squatting upon the rump, to one side of the eggs. Reaching over, she seized with the bill a piece of floating grass close at hand, and laid it across them. Sometimes she would fish out quite a bunch at one haul. If possible, she kept at it 
until the eggs were entirely hidden, when she would slide off into the water with a push of the feet that gave quite a little momentum. Some of them dove at once and came up a short distance away, while others remained on the surface. The fact of my having only head and shoulders out of water evidently made them less afraid of me than they would have been had I been in a boat. The birds were more or less scattered about in the lake, yet groups of them remained within a few feet of me, apparently trying to make out what new species of Muskrat this could be.

I should judge that there must have been upwards of a hundred nests right around me, and how many more there were off in the grass I cannot say. Certainly it was a large colony, for the whole slough seemed alive with Grebes, and all of the one species. The nests were floating quite close together, often touching one another. There was very little grass growing out of the water, and the nests were not anchored, except as they rested more or less on the floating debris. This held them in a measure, but it seemed likely that a strong wind might drive them from their location. Most of the nests were covered, and I bobbed about among them, removing the coverings to see how many eggs there were. It was evident that the laying operations of the colony were not complete, for some of the nests were empty, or had but a single egg. Only two that I saw had as many as five eggs, three or four being the usual number.

These observations made, I stayed for nothing further; indeed haste was necessary, for my sunny 
isle, whereon I had hoped to warm myself, proved to be a delusion; and I realized that submersion did not make me a Grebe, for I was already shuddering with the cold. So, hurriedly placing a few sets of eggs in the creel that I had dragged out over the water, I reluctantly returned from my birdslumland, and made for the shore, which I finally reached, shivering and shuddering, after being threequarters of an hour in the icy water. Though it was an uncomfortable experience, I was more than repaid by what I had seen. My one sorrow was that it was impracticable to use the camera.

Rush Lake is an area some twelve miles long and four wide, with water only waist deep, out of which grows long grass and occasional patches of tall rushes. Years ago, it is said to have been entirely open, but now even an open lane is a rarity. A settler piloted us to it the first day. After walking a mile or more, he suddenly announced-“Well, here we are." “ "But where is the lake," I asked, looking perplexedly over the grassy plain? "This is it, right before you," was the reply. My first feeling was of great disappointment, but as Ducks of all sorts began to fly out in squadrons along the margin, I was soon reassured.

The day after the Grebe colony incident, I spent the morning alone near the west end of Rush Lake, if end, indeed, there was, my friend agreeing to drive the team up for me after dinner. In time, I waded out to quite an open lead of water, adjoining which many Coots had their nests in the grass. Over near the other side were fifty or more Eared Grebes swimming about, evidently another colony. 


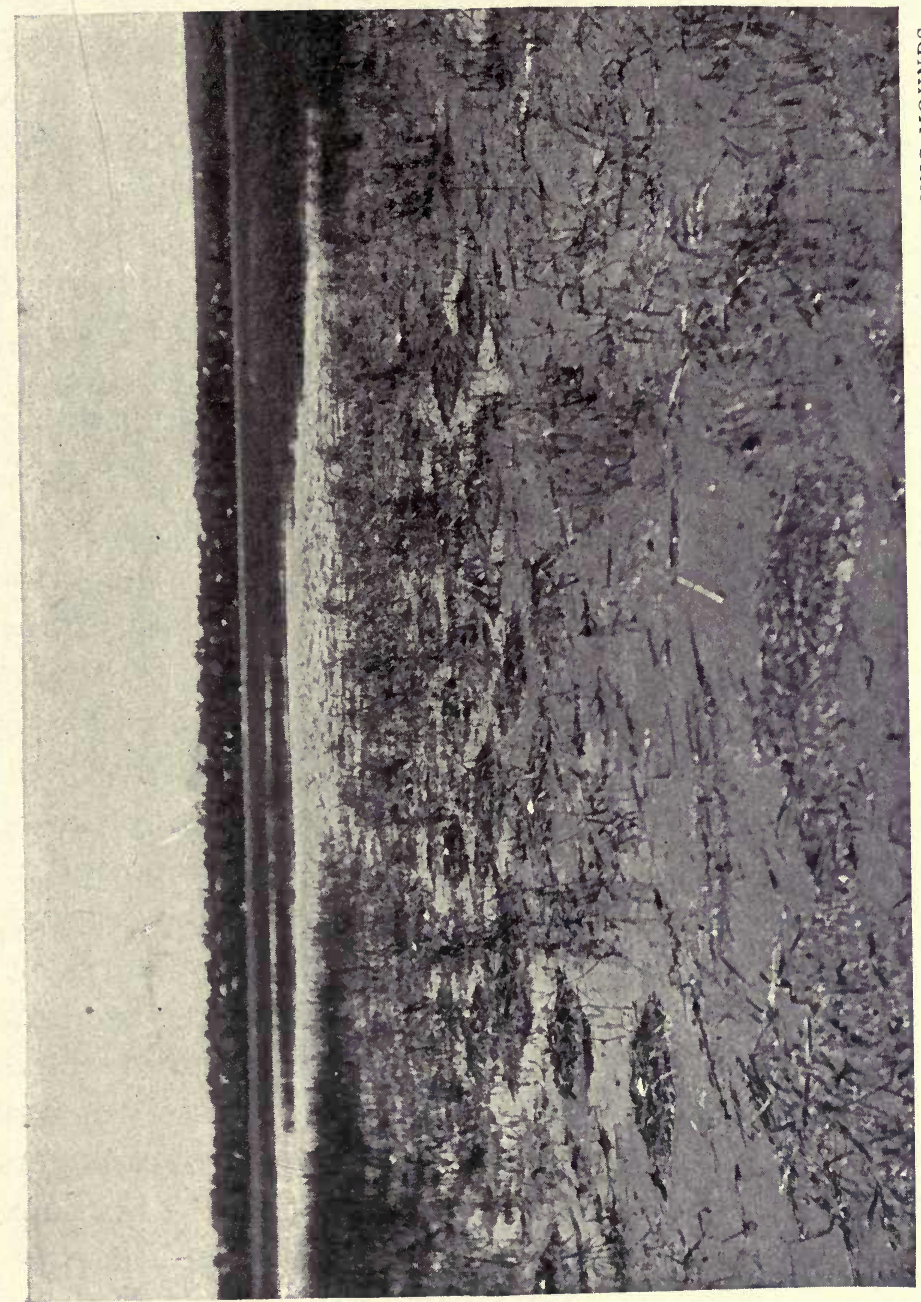

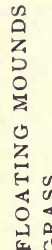

뇍ㅇ

芘

고

될

出

电告

年

过

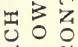

《 되

되

焉

的

은

욍 중

U 외

뙤 $>$ Z

m.

되.

of

०

(죄 외

政

程

$\mathrm{z} ;$

㟧昆

또단

这 4

40

空

is

0

范

\& 
This time I was determined not to be thwarted. So, when my companion appeared, we drove back, hitched the bow of a canoe to the back of the wagon and, after dragging it more than a mile over rough, wet ground, I managed to get afloat in it with camera and all needed apparatus. As I came within sight of the Grebes, they sank like stones, a submerged company indeed, for I saw them no more, save for an occasional head thrust momentarily out of the water to reconnoitre. One of them I saw swim under the boat, only a little way below the surface. It used wings and feet as oars, and was indeed flying through the water. But what of the nests? Not one could I find, though I explored the edges of the open water all around, and penetrated into the grass in every direction. No photographs of Grebe colonies was it that season my lot to take.

But the time came when this ambition was gratified. Late last June I was encamped, with three companions, upon the timbered shore of another large Dakota lake. One morning, we were poling a heavy boat, the only one available, through a maze of grass growing out of four feet of water, far out from shore. Another push, and we glided to a partial opening, where a wonderful sight greeted us. We had run with our boat almost into a large colony of American Eared Grebes, surprising the birds right upon their nests. Perhaps they had heard enough to arouse their suspicions, for they were in the act of covering their eggs. But no sooner did they see our heads over the grass than there was a general plunge, which sounded like the beating of a rain-squall as it first strikes a body of 
water. Every Grebe dove; but in a few moments we saw them emerge in large numbers out in the open water beyond.

Here were the slums of a larger Grebe city than I had seen before, and this time I was in better condition to inspect it. There were over a hundred of the little wet mounds close together in a compact area, and no knowing how many more further in through the grass. I did not like to push the boat in, as it would involve the overturning and destruction of a great many nests, so was content with a somewhat superficial examination of the colony. The birds had been able in every case to cover their eggs before retreating. Pulling off the layer of wet debris from a number of the nearer nests, we found that the usual number of the eggs was three, the largest five. Other nests were empty, or with only one or two eggs.

Then as we looked off, we saw, some distance away, hosts of other Grebes sitting or standing upon their floating nests, and realized that what we were inspecting was only the suburbs of the real city. Toward this we directed the boat. The Grebes, seeing us approach, slid off into the water while we were still at quite a distance, and in squadrons paddled out farther into the lake. Reaching the place, we found that a lane of water, "Broadway," I called it, divided the city into an east and west side.

On the " east side," along the edge of a tract of grass, the nests were crowded, four or five deep, for some distance. A mass of them, perhaps about thirty, extended in a sort of neck out into the open water. Conditions here, as might be expected, were 


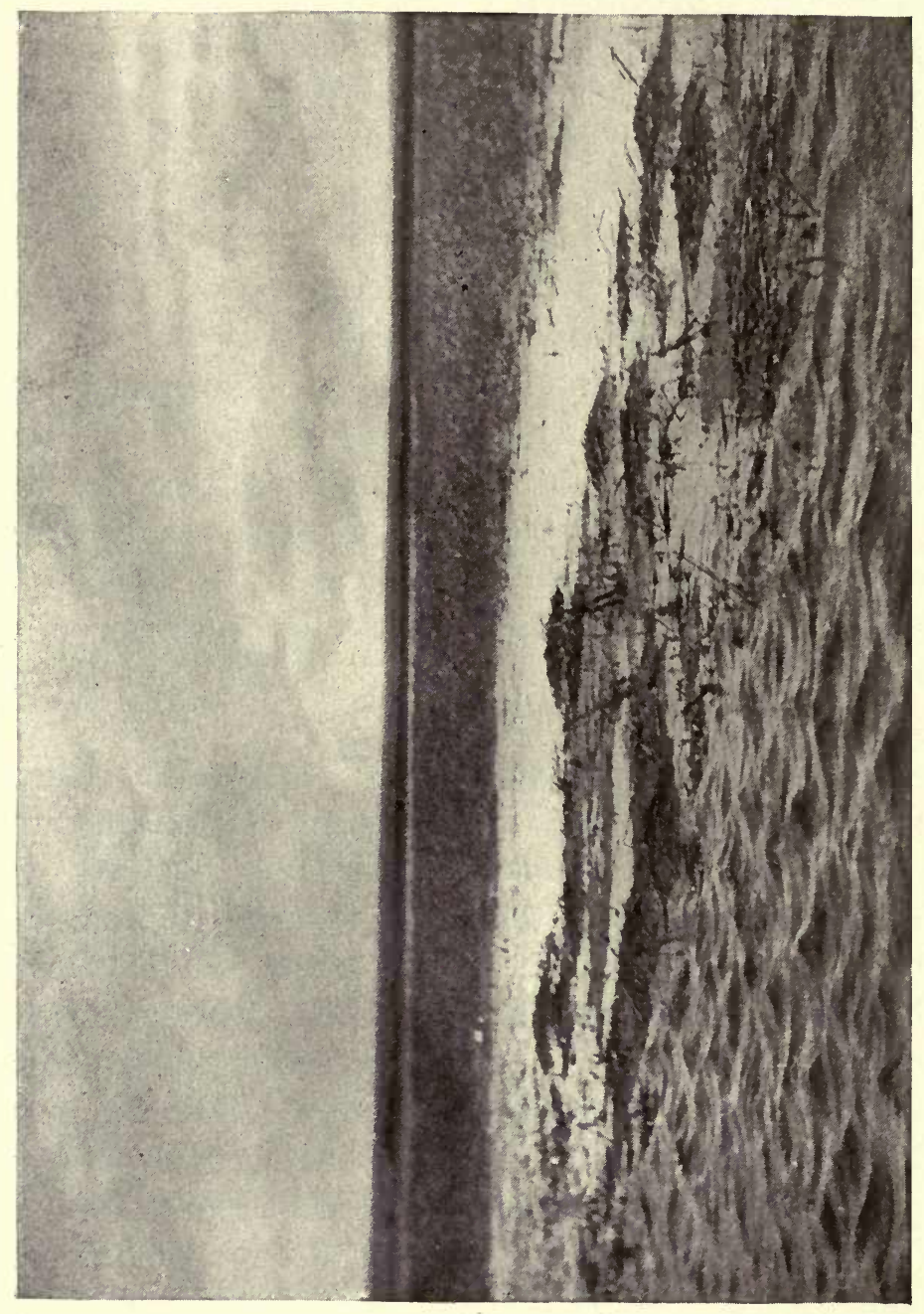

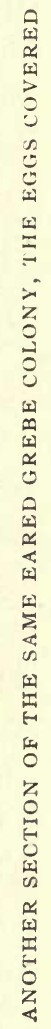


simply scandalous. Eggs lay rotting in the watery streets, in one spot as many as fifteen together, the result, probably, either of a storm or a squabble. Debris of all sorts was strewn around with utter indifference to the public health. The houses were low, untidy affairs, reeking with water and decay, huddled together in hopeless confusion. So unstable is their foundation that quite a mass of them had drifted off in some storm, and were scattered about, overgrown with green scum, the eggs washed and bleached by the overlapping water.

Conditions on the "west side" were hardly better. The congestion was even worse. Nests in close contact formed a considerable area, extending in through the sparse grass to some more open water. It seems to me that the nests in these Grebe cities are smaller and more slovenly built than where a pair build a solitary nest. The wonder is how such flimsy affairs can keep the eggs and the incubating birds above water. The husband evidently has to lead a street life, with little to occupy him except to pick up food, and receive the youngsters, which hatch one by one, and swim off as soon as they are born. Perhaps he may anticipate the mother's task, and ride the little waifs around on his back.

When at last we retired with the boat, the Grebes swam back. Some resumed incubation, while others in parties promenaded up and down "Broadway," in some cases taking their children, that had been hiding away in the grass, out for a ride. It was an odd sight to see the crop of little heads sticking out from under the parent's wing. 


\section{Among the Water-Fowl}

Before leaving, I found it easy to photograph these areas of nests from the boat by snap-shots, but a very different matter to have any of the Grebes in the pictures, as they were quite shy of the boat. Finding that they would not come near enough for a snapshot, I stood up an old tripod, with a focus cloth over the top, in the grass a little back from the "east side," leaving it for the birds to become accustomed to the sight. Next day, the wind was raging, and my companions did not think I could carry out my plan of getting out there alone in the boat to spend the day by the colony. After a long, desperate effort I managed to reach it. The birds were mostly on their nests, ignoring the tripod.

The pathway to success now seemed easy; but thorny did it prove. Moving the tripod a little nearer to the nests, I adjusted the camera, attached the spool of thread, and allowed the boat to drift off to leeward, paying out the line. So busy was I that I had not noticed a gathering squall, that just at this untimely juncture struck down with furious blast. The shutter was sprung, and I had to lose the end of the thread, not being able to check the progress of the boat in time. As it was, the camera was nearly pulled or blown over into the water. Nothing but the fact that I had spliced poles to the legs of the tripod and driven them firmly into the mud prevented what would have been to me out there in the wilderness an irreparable disaster. Then ensued a mighty struggle to get back to the camera to protect it from the rain. It was almost impossible for one person alone to push that clumsy boat through the tangle of grass and slime against the wind, but I 


\section{The Submerged Tenth}

finally accomplished it, pulled the precious instrument on board, covered it with the rubber cloth, and let the rain beat down.

After the shower had passed, I proceeded to arrange the camera again. Learning wisdom by experience, I pushed the boat across to the opposite side of the area of grass where the nests were-a distance of about the length of my thread-planted a pole firmly in the muddy bottom, tied the thread to it, and then poled back to the camera with the other end of the thread, which I fastened to the shutter. In this way there was less danger of pulling the thread prematurely, or of getting it entangled in the grass. Then I rowed around to the pole by way of the open water, tied the boat to the pole, and lay down on the bottom, thread in hand, to await developments.

After quite a while the Grebes began to swim back in small parties, and promenade up and down "Broadway." Two of them approached their nests, and climbed up awkwardly upon them. Their purpose was to cover their eggs more perfectly than in their haste they had done when the boat was approaching. As soon as this had been aćcomplished, they slid off into the water and rejoined their companions. Unfortunately they were not quite in the range of the camera, so I lost a splendid chance for an interesting picture. I thought that in the course of things they would all go back, but time passed, and not another one did so. Finally I rowed over there and uncovered some of the eggs, hoping that this would induce the owners to come and cover them. 


\section{Among the Water-Fowl}

Though I did not succeed in this, the effort was not wholly in vain, for through it I learned the reason for this habit. This breeding colony of the Eared Grebes closely adjoined a far larger one of thousands of the Franklin's Rosy Gull. Hardly

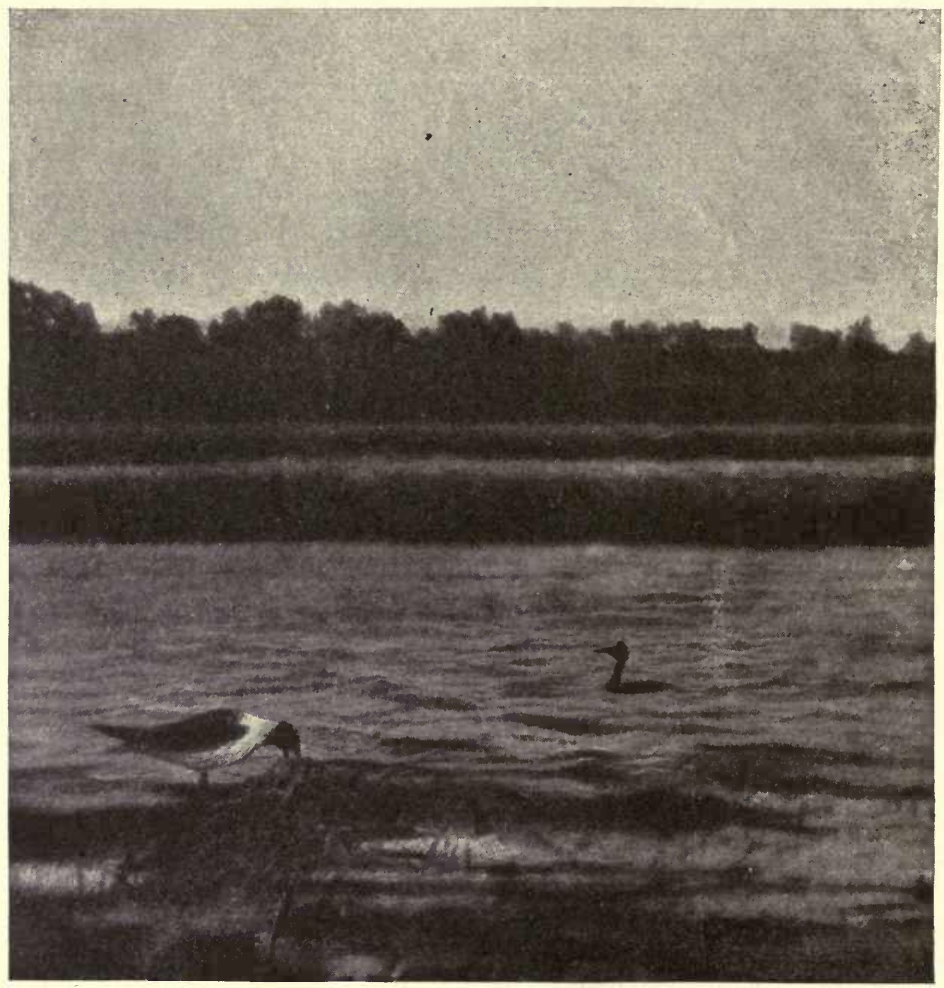

A FRANKLIN'S ROSY GULL EATING EGgS OF EARED GREBE, ON "EAST SIDE." THE OWNER WATCHING.

had I returned to my anchorage, when a Gull alit upon one of the nests which I had uncovered, and proceeded to pierce the eggs with its bill and devour the contents. I pulled the string and exposed a plate upon this interesting procedure. The picture 


\section{The Submerged Tenth}

shows the Gull with its bill thrust down into an egg, and a single Grebe in the water just beyond watching attentively what was probably the spoliation of its home. Perhaps it was fear of the camera that prevented the naturally expected attack upon the marauder.

Another plate had then to be inserted, which I finally exposed when a party of Grebes were swimming by, just in front of the nests. These were the only two pictures secured in the greater part of a day of hard labour and nerve-wearing toil. After this the thread became almost hopelessly tangled, and, despite long, exasperating effort, I got only another fogged plate at about sundown. And it was the last chance, too. Then, as I was taking up the camera, at eight o'clock and after, it dawned upon me that I had forgotten to eat my dinner, though I had it with me in the boat. When I returned to camp almost at dark, the company made merry over a fellow so much interested in birds that he needed a caretaker to remind him when he must eat. " A veritable rustic," perhaps the Grebes had been saying, staring all day, openmouthed and absent-minded, at the sights of their great city.

Within ten miles of this spot was another equally interesting, though very different Grebe-city. Extending far out from the shore, in water waist deep or more, grew a great area of canes, ten or twelve feet high. To get at it from where we had pitched our tent, I had first to wade across an arm 


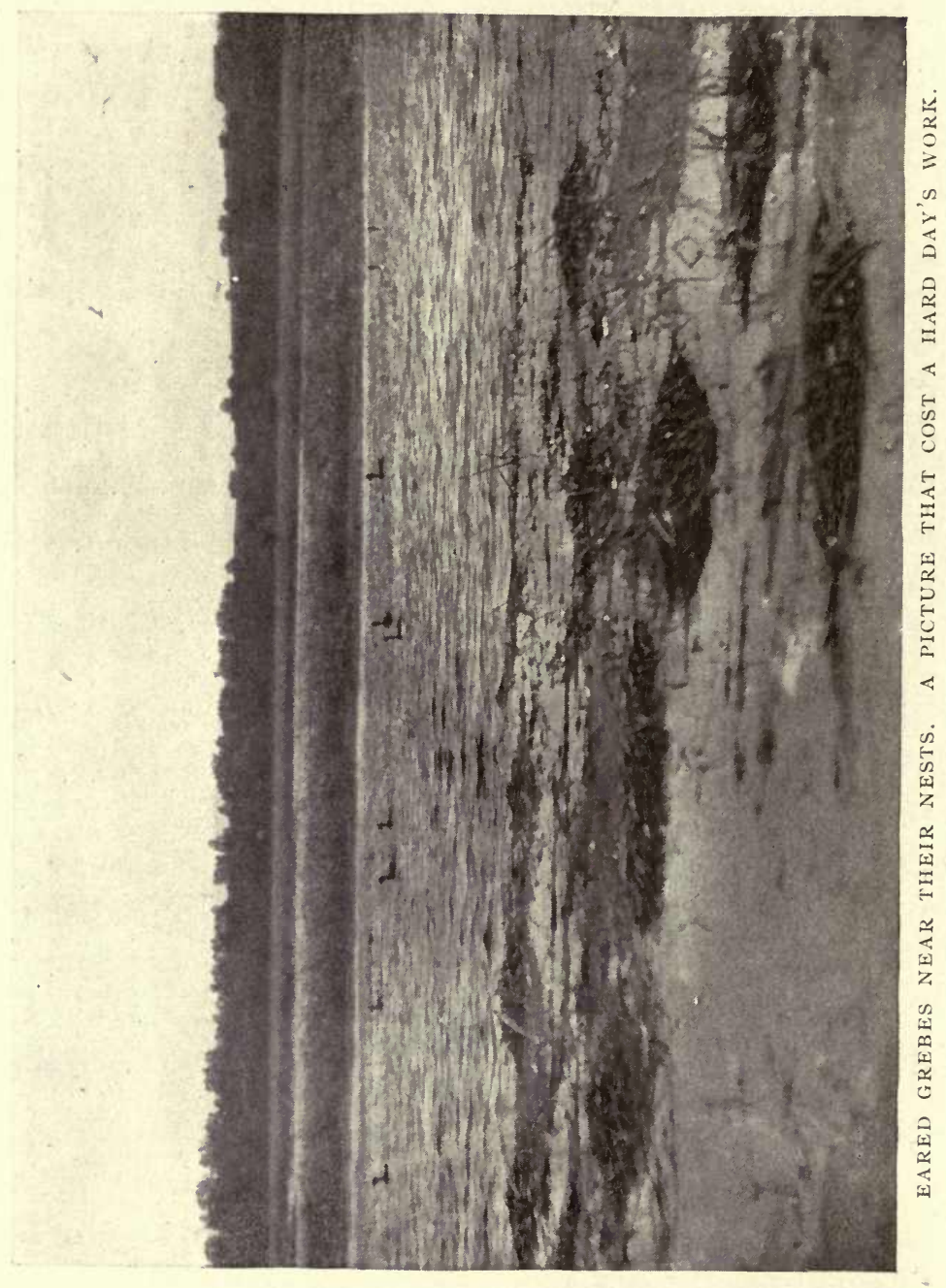




\section{The Submerged Tenth}

of the lake, shoulder deep. Then, after walking a mile along the shore of the lake, clad in a suit of underwear for protection against an abounding poisonous water-plant, I forced my way in through the thicket of canes. About a hundred yards from the shore I entered the suburbs of the city inhabited by the Western Grebe-a great loon-like

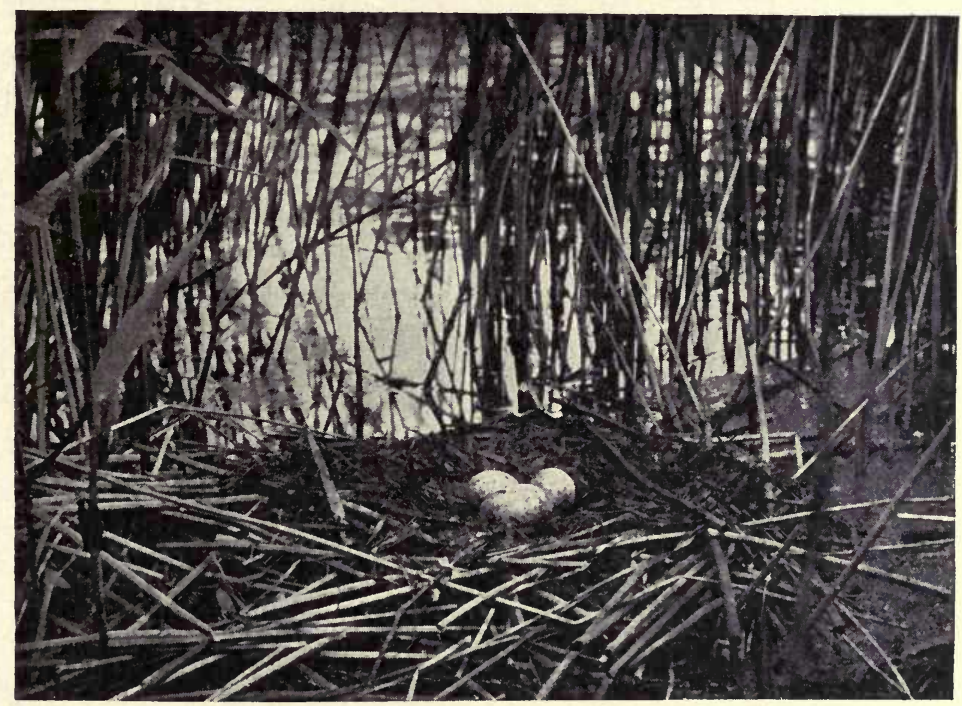

- one of the many Nests of the WEStern grebe

creature, the largest species of the order-and the Eared Grebe. In the shadow of the tall canes I seemed to be in some sort of a submerged tropical forest. The leaves of the canes were thicker towards the top, while lower down the stems were bare, like miniature palm-trunks, through which one could see only for a few feet. In this shady retreat, floating between the stems, were the nests of the Grebes, on the average about two yards apart. 
As I slowly waded along, I could hear a constant succession of splashing, plunging sounds, as the birds dove from their nests to swim off under water. When I stood still for a few moments, they would return and suddenly emerge, sometimes within a yard of me, only to plunge again the instant they caught sight of the intruder.

These grebe-homes, especially of the larger species, were quite substantial affairs. Even the little "Eared" fellows made better nests than in the other city where they were so huddled together. Possibly they were trying not to be outdone by the "Westerners," or else the latter, who were in the majority, had enacted certain building regulations within the city limits! Yet, though the homes were larger, it was evident that they belonged to the lower classes of bird society. This city, like the other, was shamefully dirty. Eggs and even dead birds lay rotting in the water between the nests. The odour was so unpleasant as almost to nauseate our guide, who afterwards ventured in with me. As for myself, I was so much taken up with the novelty of the situation that the " mindcure" effectually performed its work.

How far the city extended, and what was its population, I made no great effort to ascertain, as even a moderate degree of progress was very difficult. Wherever I went there were nests, acres and acres of them. In parts of the town the larger species dwelt alone; in others the nests of the two kinds were intermingled in about equal numbers. Three eggs was the usual complement in the nests of both species, often four, but more than that I did 


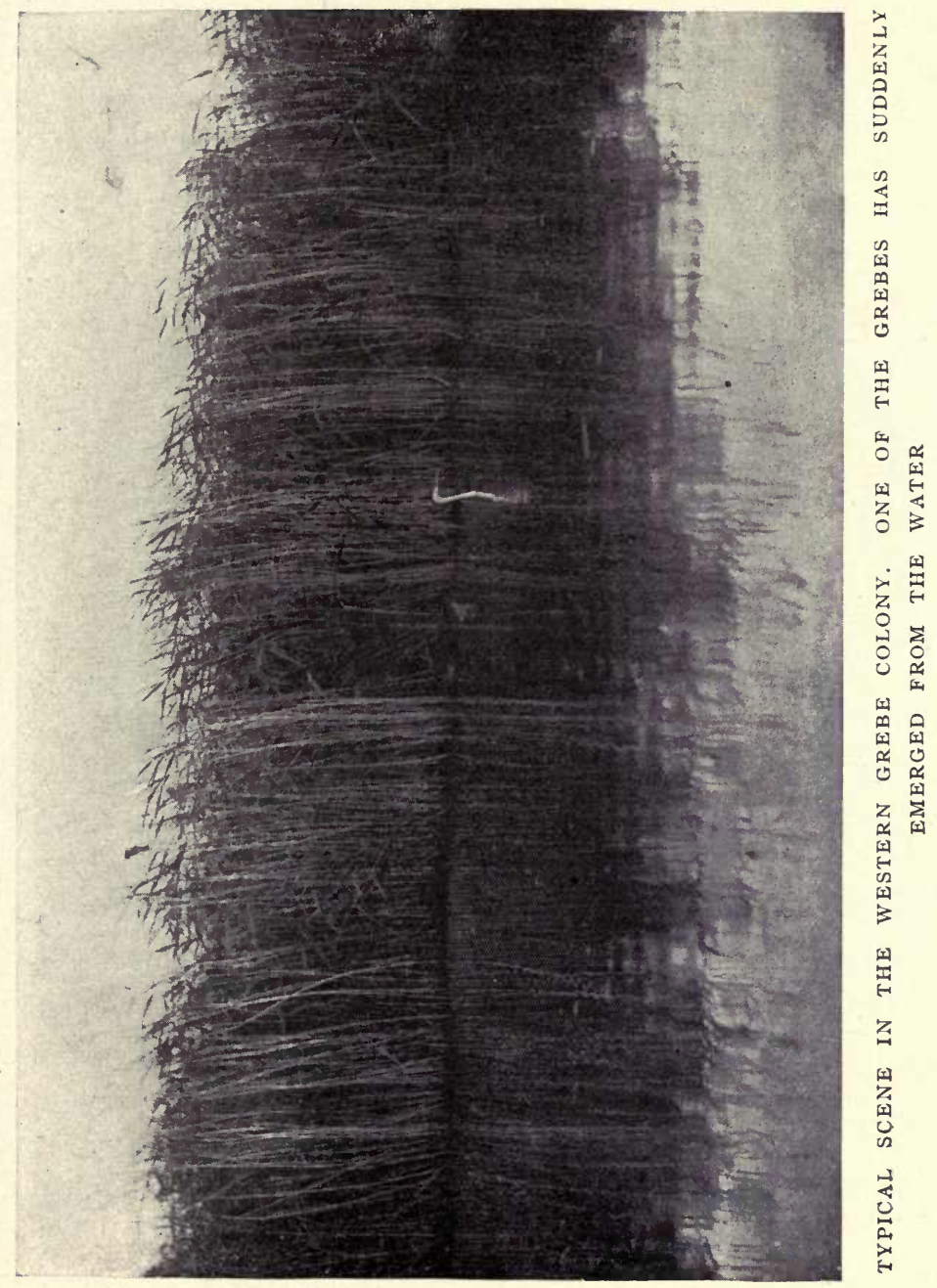




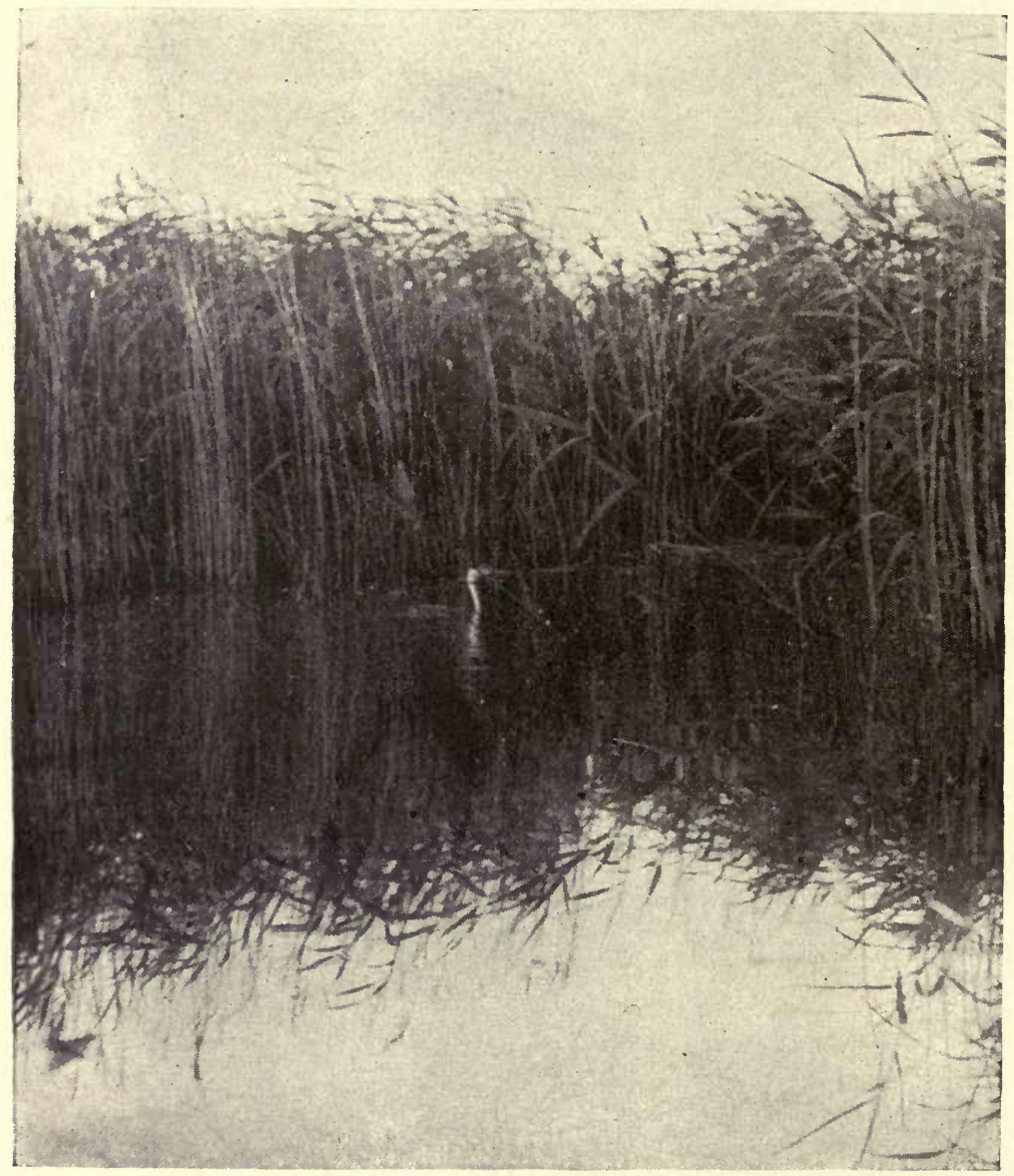

A WESTERN GREBE IN A "CITY PARK" 


\section{The Submerged Tenth}

not discover, except where a Grebe of either kind had laid in a nest of the other. It would be interesting to know what is the state of mind that causes various species of birds that colonize together to lay in each other's nests. It may be through mistake, yet, as in the present case, when the eggs of one kind are twice the size of the other, it seems as though the bird would detect the difference. I can imagine, on the other hand, that the little Grebe might find the larger nest attractive, but not so readily what the big Grebe thinks as it finds the smaller home which it has usurped about sinking under its weight.

There were no street-signs in the city, and, though city bred, I found myself rustic enough to be in danger of getting lost in the colymbine (Colymbus) labyrinths. As luck would have it, the usual daily June thunder-shower (of this season) came up before I was half through my exploration. Covering the camera and plates with the rubber cloth, my upper half was soon as wet as the rest. For a considerable time the sun was obscured. There was no way of looking over the tops of the canes to note the direction of the shore, and I might have wandered about there indefinitely, had not the welcome sun again shone forth. Next time I brought a compass, and felt more secure.

Here and there in this city were pond-like openings in the canes, with open water, the city parks, I called them-breathing-places for the Grebe-multitudes. Standing in water waist-deep or more by one of these, I shivered and watched the ways of the Grebes. This opening was some thirty 


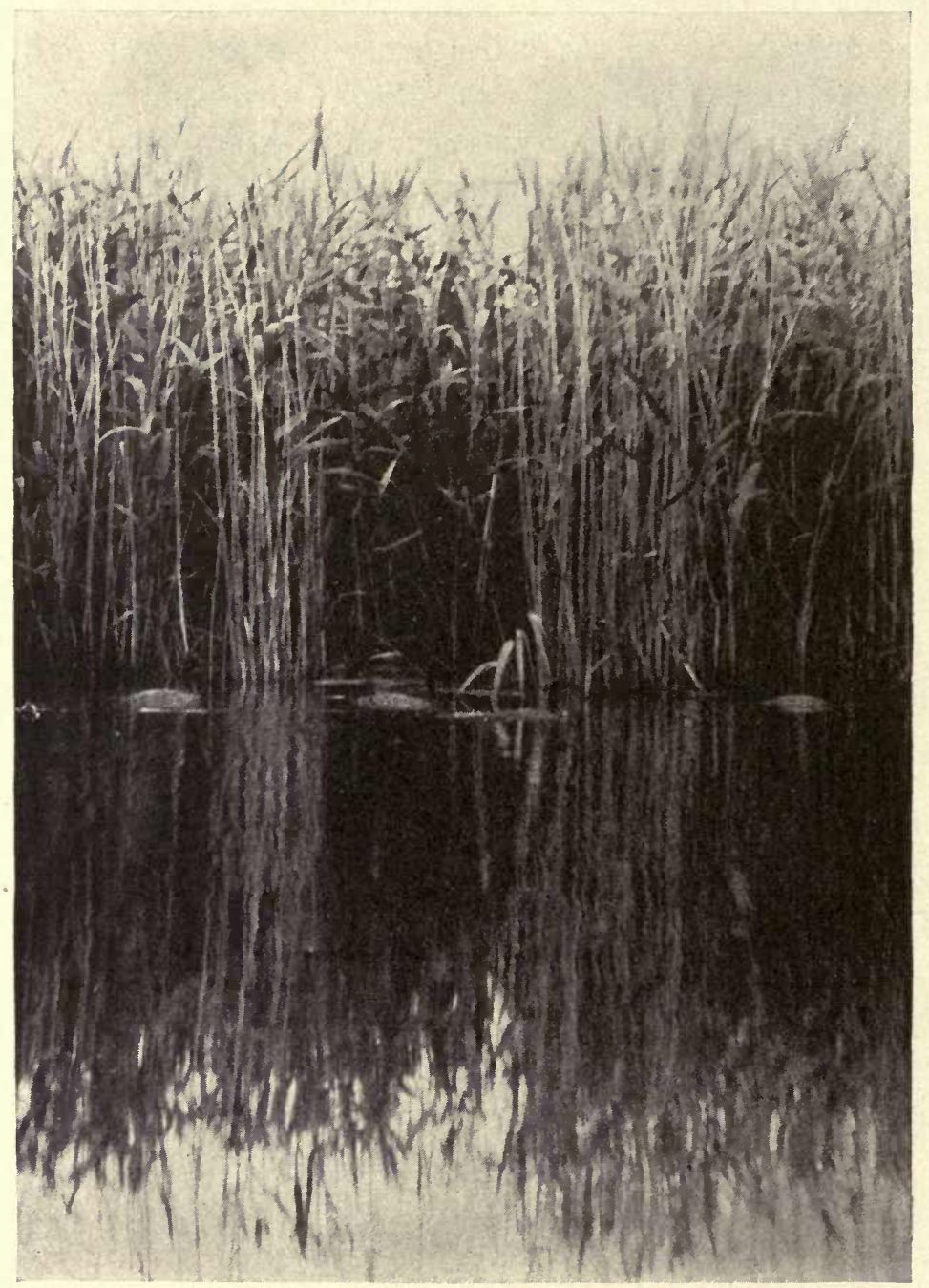

"NOW AND THEN A SMALL GROUP OF THE EARED GREBES WOULD . . . PADDLE ACROSS THE OPENING" 


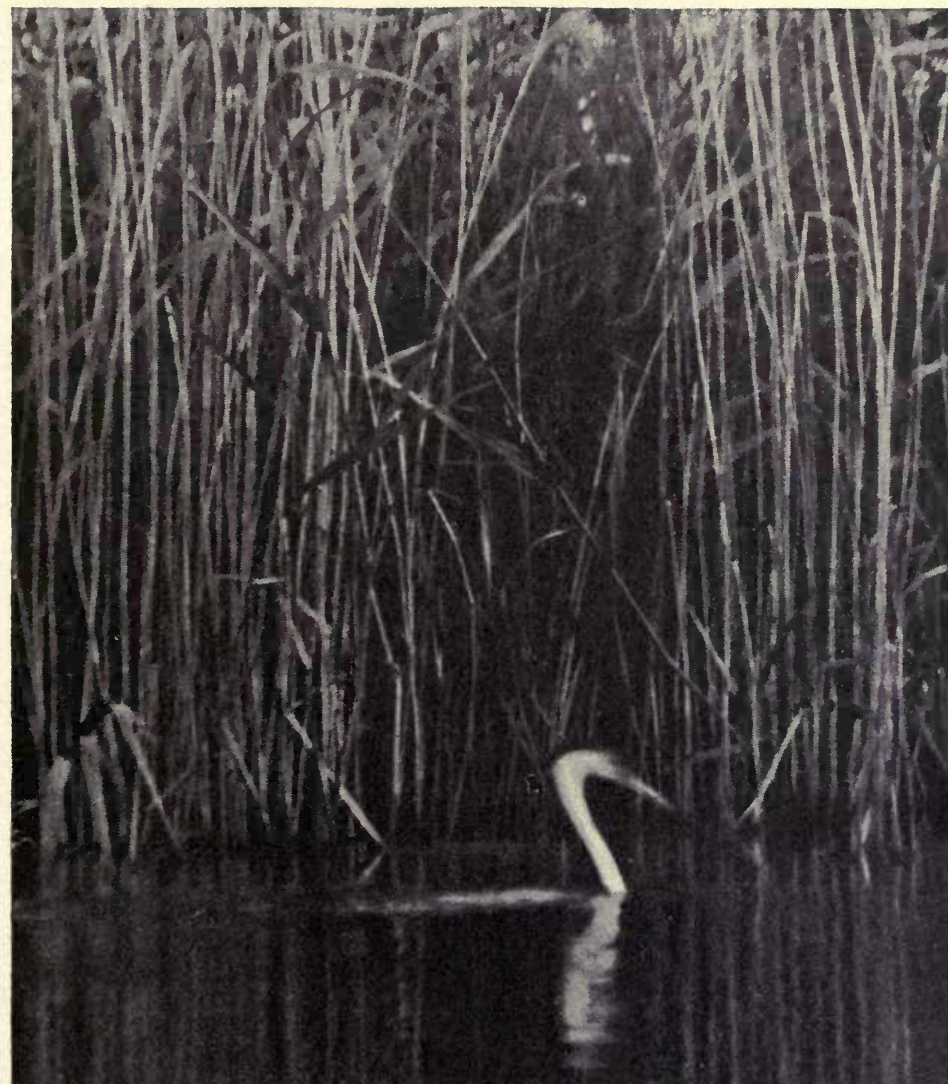

A WEStern GREBE 
feet in diameter, and was surrounded by nests in the adjacent canes. The owners had been frightened away, but, as I stood quietly, they would emerge from the open water as a convenient place for more extended observation, take a look at me, and then dive. I found that by standing back a little in the canes they did not notice me so much, and, somewhat reassured, would promenade across the park, back and forth. Now and then, a small group of the Eared Grebes would swim out from the reeds, gaze around, and paddle across the opening. One of these Grebes brought out a chick for a ride. The little one was under the parent's wing, only its head sticking out, seemingly having a fine time. Then one of the great Western Grebes would break water, and swim with only its long slender white neck out, and the merest suggestion of a back, looking more like a water-snake than a bird. Here was an opportunity for Grebe-photography which I eagerly improved. Planting the tripod at the edge of the canes, I arranged the camera, using the ampliscope lens to secure a larger image, and focused on the further side of the park, where most of the Grebes appeared. Then, with a thread attached to the shutter, I retired a few paces, and took snaps at various Grebes of both sorts, till gathering clouds compelled me to desist.

I had been wondering what was the cause of the evident destruction of life in the Grebe-city. As I stood there motionless in the canes, a partial solution was suggested. A nest of the Western Grebe with one egg lay almost within arm's reach. Suddenly a large Muskrat emerged close by, and 


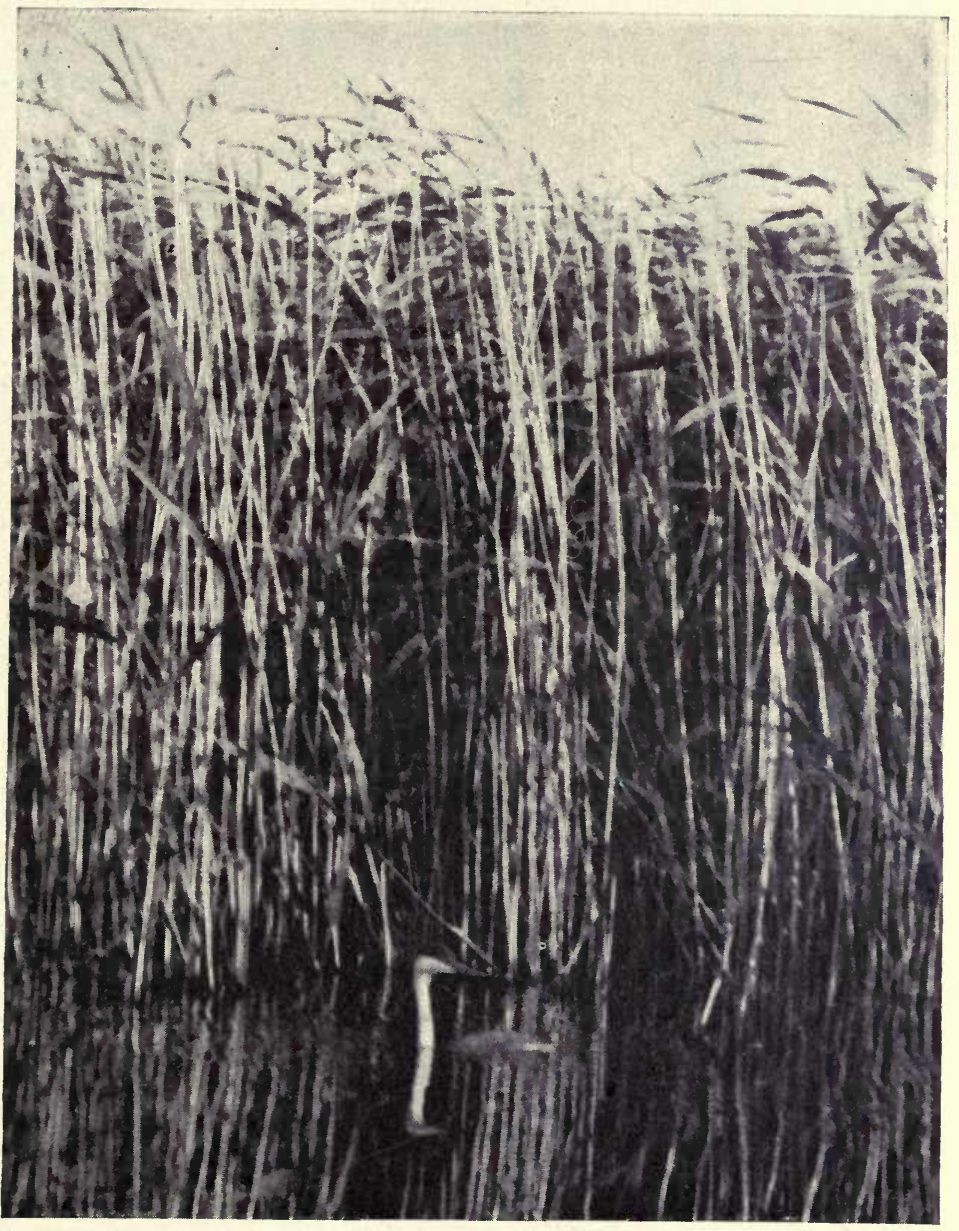

ANOTHER WESTERN GREBE 


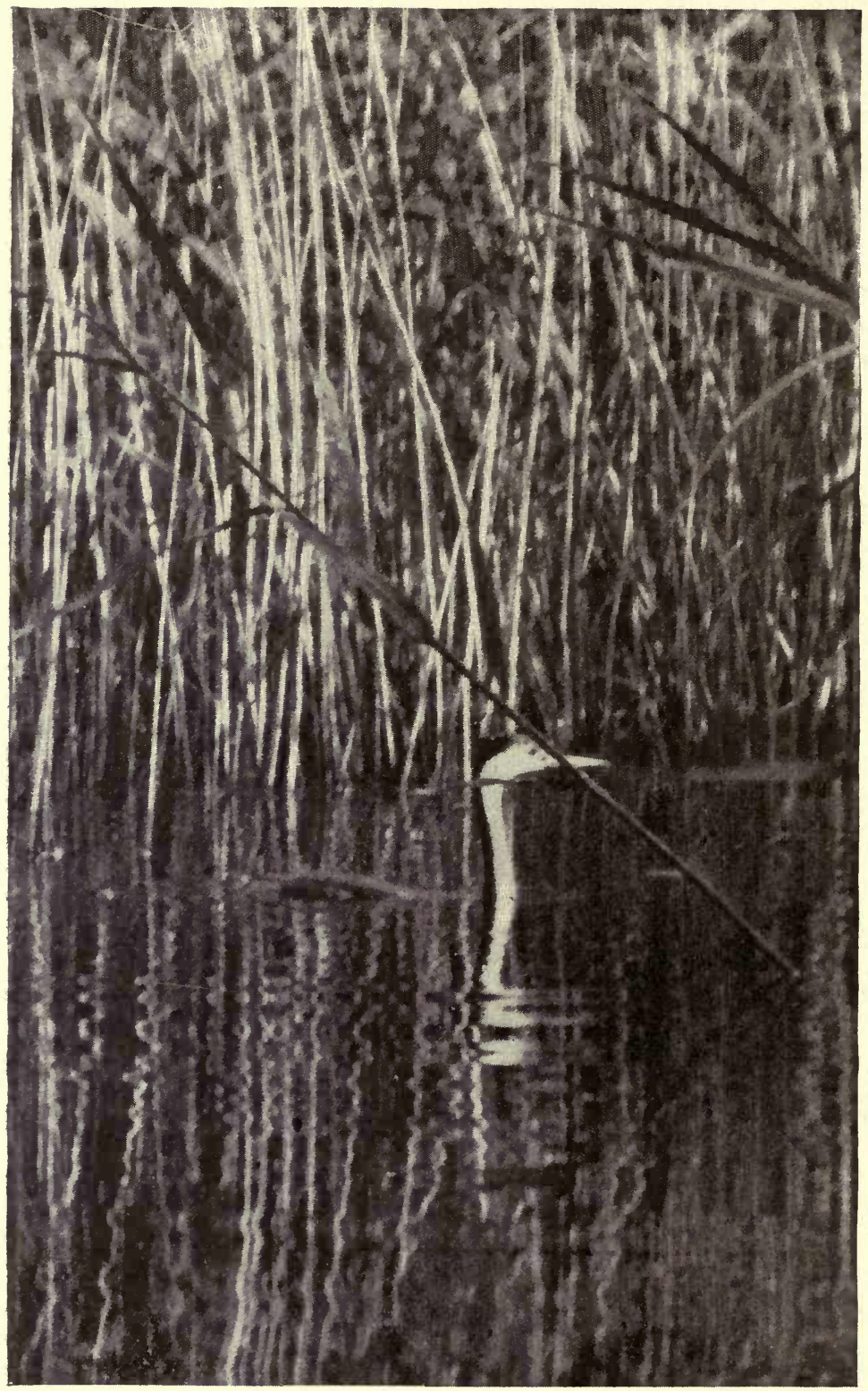

STILL ANOTHER WESTERN GREBE 


\section{The Submerged Tenth}

crawled out upon the nest. First he glanced around, and though looking right at me, did not seem either to perceive or to care-I could not tell which. Next he smelled the egg all over, poking it with his nose. I thought I would now catch him redhanded. But either the animal was looking for something else, or scented danger, for directly he ambled down to the water's edge and plunged. Muskrat houses were numerous, and it is hard not to suspect the occupants of enjoying something more than a vegetable diet. If guilty, however, Minks may also have a share in shedding Grebe-blood.

By this time I was chilled and shivering, so began the retreat, and, after two hours and a half of exposure, was glad to set foot on dry land. The Grebes had a splendid city, no doubt, according to their ideas, but I did not envy them at all their happy, slovenly ways, or their wet civic prosperity.

Another interesting jaunt was into the Turtle Mountain country, the wooded area of Dakota, some two thousand square miles of low, rolling, rocky hills, covered with a growth largely of poplar. Every hollow between these hills is occupied by a lake, varying in size from "Fish Lake" in the interior, a number of miles in length, down to little ponds of a few acres. They are entirely different from the marshy, shallow prairie lakes, or sloughs, being clear and deep, with pebbly bottoms, though there are a very few that resemble the sloughs. The woods grow nearly or quite to the water's edge, and there is a border of round- 
stemmed reeds for a few yards out. They are much like the typical New England pond, and, like them, have-comparatively-few water-fowl.

There are some, however, and one of the most characteristic I found to be the large Holboell's Grebe, the only Grebe, in fact, that I saw in the region. I met them only in solitary pairs, nesting

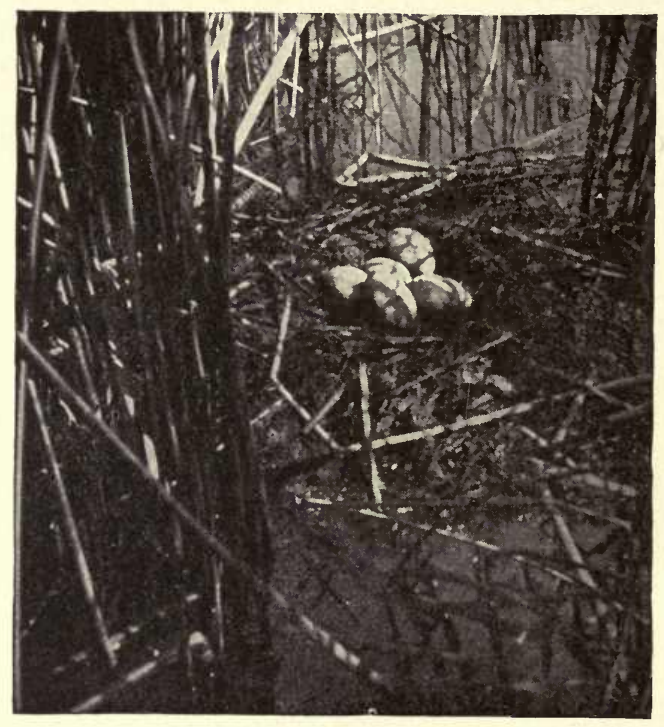

NEST OF HOLBOELL'S GREBE in the outer edge of the reeds on the shores of the ponds. One of the first birds that I noticed as we drove in from the prairie was one of these Grebes swimming in a small pond near sume reedy clumps. Next day I walked back there. The bird was on guard, and its mate swam out from the reeds at my approach. There was the nest amid the reeds in about three feet of water, a large floating pile of wet, decayed stems. The five dirty white eggs, as large again as those of the Eared Grebe, were covered. With some drift-wood I managed to arrange a standing place, from which I photographed the nest.

Usually but one pair was found in a small pond, and when, in the larger ones, there were several, 
no two nests were very near together. The habit of the birds on these clear lakes of patrolling near the nest renders this very easy to find. I liked to stand still, nearly hidden in the reeds, and see the graceful lovers, close together, glide in so near to me that I could note every detail of plumage and motion. The red patches on the sides of the neck fairly glowed in the sun, as though they might easily do the same at night of their own radiance.

During my stay in the Turtle Mountains, I found several nests of the Holboell's Grebe. One was of more than ordinary interest. I saw the bird swim out from the reeds, as usual, and right there was the nest, with three eggs and the two segments of the shell of a hatched egg. The youthful occupant had evidently just emerged, and there it was in the water, trying to follow its mother. I waded farther out, and the little fellow, either in confusion, or seeking a friend, swam back to me, looking up into my face. I picked it up, a curious tigerstriped thing, so long and slim that it reminded me of a weasel. Then I replaced it in the nest, but at the first opportunity it scrambled out, and disappeared among the reeds. In two of the eggs I could hear the young chirping.

I went back to camp for dinner, and then returned to the Grebes' nest. On the way I investigated the home of some Purple Martins in a Flickers' hole, well up a tall, slippery poplar stub, finding, after a hard struggle, that the nest contained five eggs. This species, Barn and Tree Swallows, Bronzed Grackles, Flickers, Downy Woodpeckers, Sapsuckers, House Wrens and Red-tailed Hawks I 
found to be the common species of the poplar growth, with a few Sparrow Hawks, Song and White-throated Sparrows, Mourning Warblers, and doubtless other small birds, sprinkled in. No more of the Grebes' eggs, I found, had hatched, but the loose egg-shells were gone, as was the youngster. One of the shells I found about ten yards from the

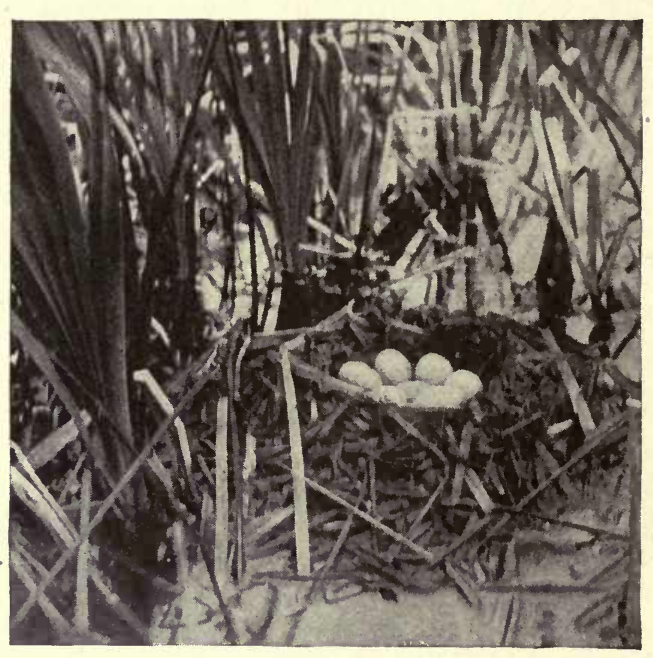

NEST OF PIED-BILLED GREBE, NORTH DAKOTA nest, floating among the reeds, whither the old bird, no doubt, had carried it.

Th is large Grebe seems not very common in Dakota, though I met it sparingly in the larger fresh water lakes. But everywhere in the prairie sloughs one meets the familiar Pied-billed and Horned Grebes, as well as the Eared. I did not find these first two in colonies, but each pair nesting by itself, usually well out in the deepest water. One day I was exploring a large slough in a boat that I had carted miles for the purpose, when I came upon a small Grebes' nest with one egg, out in nearly open water, anchored to a few stems of grass. Quite near it was a Horned Grebe that probably was the owner. The wind was violent, and the waves were breaking over the nest all the time. Probably other eggs had been 


\section{The Submerged Tenth}

washed out, for it was late in the nesting seasonnearly the last of June. This must be a very common occurrence, for the Grebe will not learn wisdom. Yet even though the creature itself be submerged, it is hardly to be supposed that submerged eggs will hatch, or that the deluge here in

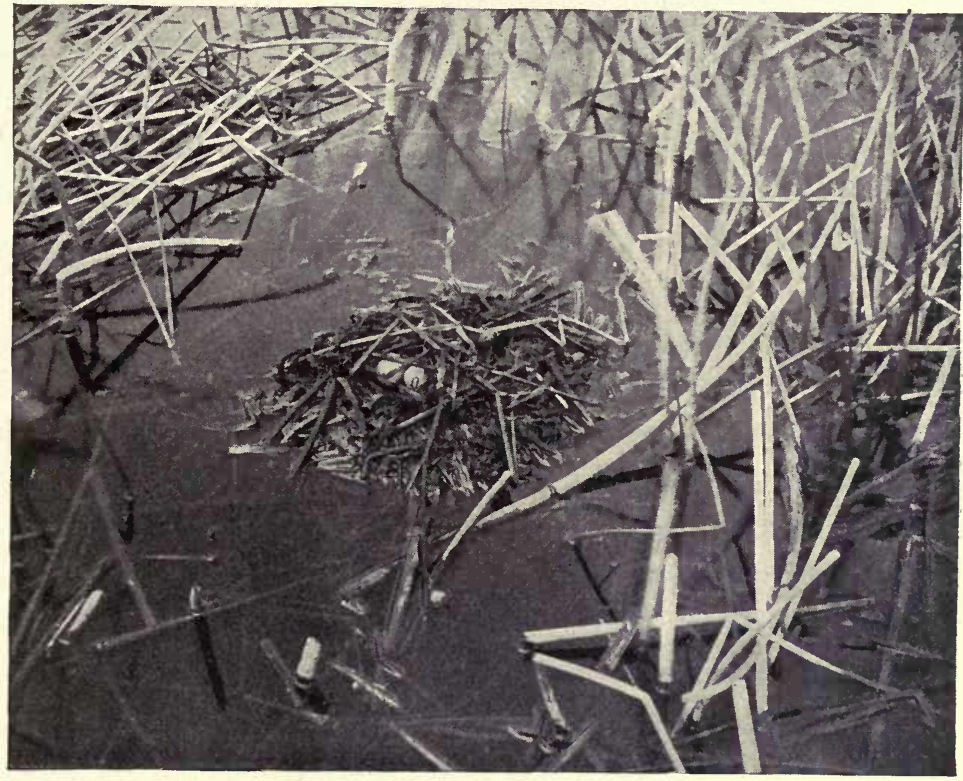

ANother pied-billed grebe's Nest Within a FEW RODS OF PRECEDING, CONTAINING NINE EGgS, AS COVERED BY THE OWNER.

BY A. C. BENT

progress was altogether pleasing to the otherwise contented "Water-witch," unless for the fact that the surviving egg was much cleaner than usual.

It is no easy matter to identify scattered single nests of the smaller Grebes. Seldom, except in colonies, have I been able to see a Grebe actually on the nest. A very common and well-known 


\section{Among the Water-Fowl}

habit of theirs is, on warm days, to cover the eggs with wet debris, and leave them for the sun, and the heat generated by the decaying vegetation, to act upon. And it is remarkable how generally they hatch. But it is not true of any species that they never incubate on warm days. In one instance I saw a Horned Grebe on its nest in early afternoon. Many a time I have come upon single nests whose eggs were uncovered and very warm. There is almost invariably, in such cases, a protecting screen of rushes, and the bird evidently has just slipped off before being seen. However, in one way or other, the owner of the nest is almost sure to be out of sight when the observer approaches. Sometimes the three smaller kinds all nest intermingled in one slough, and then the confusion is nearly hopeless. The only way to identify them is to hide some distance away and watch. After a time one or both owners may appear, and, by patrolling near the nest, show their interest and decide the ownership.

If the number of eggs is large, they are quite apt to belong to the Dabchick, as they probably do anyhow, if the locality is in the eastern United States. Still, I have known the Horned Grebe to lay as many as seven. Last summer I was in a slough where the Dabchick abounded, and I found the largest Grebe-set in my experience-of nine eggs. Five or six seems to be the usual number for that species to lay, four or five for the Horned, and three or four for the others.

The time was when I supposed that Grebes were very silent creatures. But camping by a little 


\section{The Submerged Tenth}

open lake which was frequented by a pair of Horned Grebes, I was able to trace to their authorship certain loud cries of whose origin I had been uncertain. The sounds began as a quick chatter, ending with several prolonged notes that I can only describe as yells. They seemed to keep up this noise all night, for I often lay awake listening to it, not disturbed, but thoroughly enjoying it, thinking how fortunate I was to be living in such good company! By day, when the water was calm, I could see flocks of Grebes out on the larger lake near by, and hear from them the same or similar quaverings. First one would cry out, then another would take up the strain, and still others, until there was noise enough for the most ardent lover of bird-choruses. And no less peculiar are the cries of the big Western Grebe, which I heard on all sides as I waded about through their colony in the canes. They are utterly different from the notes just described-a shrill, grating trill, not nearly so loud, with a metallic quality, all in one key, like an " anvil chorus," or even the tinkle of a small alarm clock.

My experiences with Grebes in the East have been of a very different order from those of the prairie sloughs of the West. Here I have known them largely as migrants, or winterers on our bleak coast. The exception to this was a delightful sojourn among the Horned Grebes in their summer haunts on the Magdalen Islands, in the ponds near "East Point" which Audubon refers to in his 


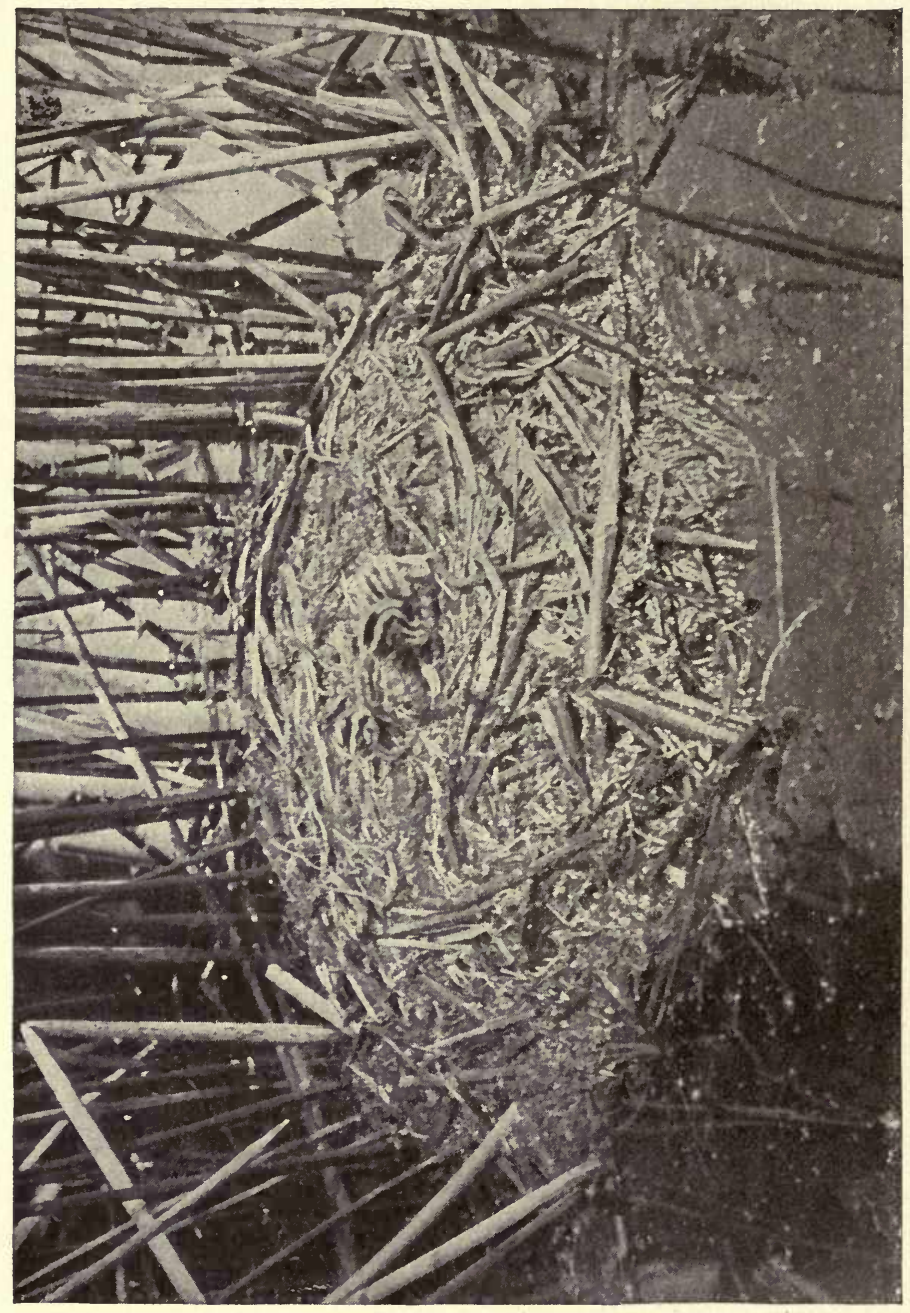

(19)

$\approx$

(1) 외

$\simeq \circlearrowright$

红近

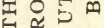

음

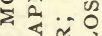

되 조 되

界及业 $n \geqslant$ 纹 $4 \times 7$

$0 \leq$ 되 외

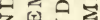

《国了。

की

在

乙 되웜

[I] 20

$<\mathrm{ZZ}$

党

0,5

《5

的密

- iो

되는

乙 4

b)

즌

$\Rightarrow>$

4 응

年

我空

运

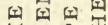

편요

Z证雷

田四了

난?

公

只

$>$ 는

언

a $>a$

的兵

岳趈

is 4

$0 \%$

3

5 


\section{The Submerged Tenth}

Journals. Here they were the only Grebe, and nested abundantly, one pair to each of the little ponds, and several each to the larger ones, building floating nests out in the reeds, as usual. The Dabchick also nests in the East-from New England northward. It rarely, however, remains as far south as Massachusetts or Connecticut, so I have had to await its advent in September to our retired ponds.

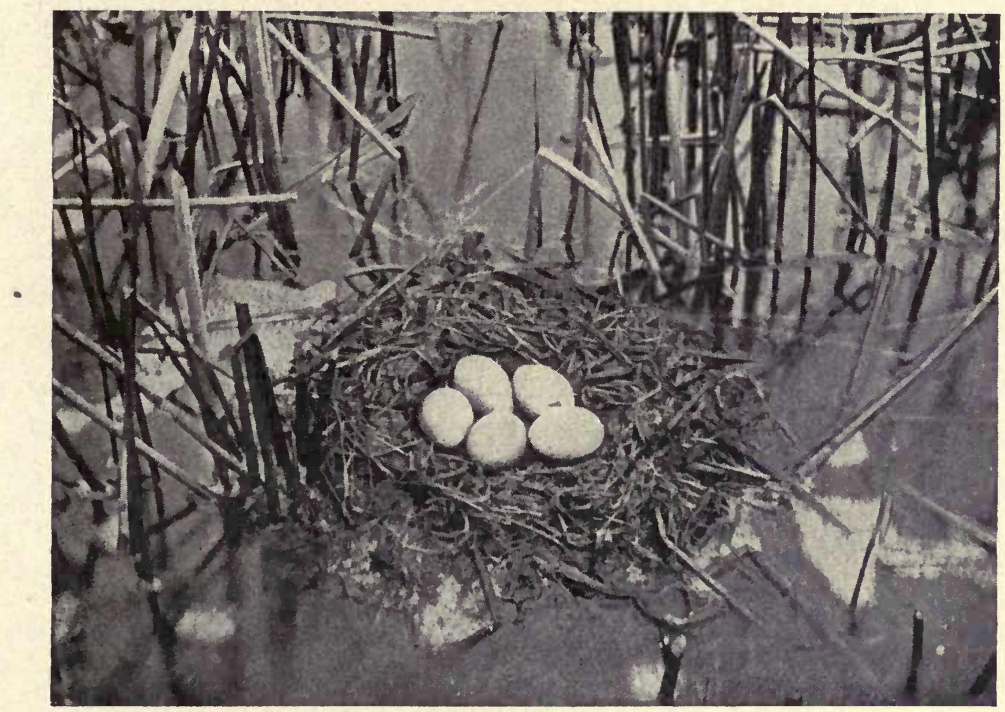

NEST OF HORNED GREBE, MAGDALEN ISLANDS

By October, the Horned Grebe. looking utterly unlike the fine fellow of the sloughs - as is the case with the other Grebes as well-appears in the larger lakes and on the coast, followed by the larger Holboell's Grebe. But none of them are more picturesque to me than the little brown Dabchick. I associate it with a lonely pond, in the crisp air of October, surrounded by forests made gorgeous by 
the touch of the frost. There near the shore the curious creature glides about among the lily-pads, dabbling in the water, and gathering food as it goes. Then it pauses, and rests quietly on the glassy surface, glancing around to see if all is well. Suddenly, with a quick plunge, it is out of sight, and after about a minute rises not far away. Then it will lie over on its side and preen its feathers, the light glancing resplendent from its white, silky under parts.

The Dabchick, as are other Grebes, is a masterly diver, skilled in eluding the shots of the hunter. Other birds might well aspire to unite their fortunes with those of " the submerged tenth," could they thereby secure that immunity from harm. that the power of diving would make their lot. As a boy, when I at last captured a Dabchick for my cabinet, I felt like a veritable hero. It is laughable to me now how one day I stood on the shore of a pond near Boston and fired a whole pocketful of cartridges at an inoffensive Grebe a few yards away, without-I am now glad to say-harming it in the least. It would rest quietly on the water, all alert, never turning, even for an instant, its bright eyes from me. The moment I pulled the trigger it would plunge quick as thought, reappearing in a few seconds, I could imagine, with a mocking smile, ready to try again. It seemed to find more sport in the affair than the excited hunter. Nowadays I am plotting, not to destroy the innocent things, but to trick them to pose before the camera.

I thoroughly enjoy cruising about in a sail-boat on a bright day with a good breeze in late fall on 
beautiful Assowompsett, in the largest lake in Massachusetts. Nearly always I can find the Horned Grebe, often the Dabchick, and occasionally the larger species, though the latter here prefers salt water. The Grebes usually migrate in flocks, unless it be the Dabchick, but on alighting in a lake they scatter about searching for food. So, as I run out on the first tack, I am apt soon to see a solitary Grebe of some sort, paddling about. Pretending not to see it, I work the boat well to windward, and then, with extended sail, which serves to hide me, bound along at a rapid rate, almost directly toward the bird. The approach is so sudden that the Water-witch seems for the moment to lose its self-possession, and swims first one way and then the other. And now we are so close that the Grebe in fright feels that it must do something, so it does what is most natural, dives. Instantly I luff the boat, and as likely as not the bird will soon emerge almost alongside, thinking to have come up far behind the moving boat. Hardly are its eyes above water than it sees me, and dives again so quickly that often. I only hear the splash and see the swirl of the water where it went down. This time it will swim a long way, raising only its bill now and then above the water for a breath of air, so I run the boat off before the wind in search of another bird.

If it is quite windy, the Grebe can sometimes be made to fly. The start is a very entertaining affair. Having very small wings, it is hard for it to get out of the water, though, when once started, it flies easily and swiftly, with rapid beats of the 


\section{Among the Water-Fowl}

wings. At first the poor thing goes pattering and fluttering along the surface, often to fall in again, exhausted by the effort. In this case, after a brief rest, swimming a little for a start, it may try again, or else give up and dive. It is especially hard for it to rise from rough water, with breaking chop. One mid-winter day off Chatham, Mass., with an easterly wind and breaking sea that hurled the fishing sloop onward, we overhauled a Horned Grebe that made desperate efforts to fly. Rising, as do all water-fowl, toward the wind, it would almost get under way when a breaking surge would insultingly slap it in the face, and knock it back into the water. One large wave fairly flung it backward, making the poor thing fall all in a heap. With great persistency it tried five or six times, when the boat had come so close that imminent danger compelled it to abandon the fruitless attempt and dive.

Some few of the Horned Grebes, and more of the Holboell's, remain all winter on the New England coast, and in the spring visit the ponds again, the larger kind as soon as the ice is gone, in March. Both of these follow the coast-line in autumn in flocks, at the same time as the migratory ducks. The first time I ever anchored in a "cooting line "-off Scituate it was-I soon saw to the north a rapidly approaching file of small, whitewinged fowl. As they passed close to my boat at the rate of over a mile a minute, I sent two shots singing after them. One bird left the line, and went ricochetting over the water for many a rod. Rowing from the mooring to pick it up, I was 


\section{The Submerged Tenth}

surprised to find that I had secured, not a Duck, but a Horned Grebe. This was my first successful wing-shot from a boat, and no wonder I remember it. More often, under similar circumstances, it has been the large fellow_-"Ting-tang," as the gunners name it - that I have observed.

A mental picture such as the above inevitably has Loons in it, as a natural part of the scene. Though Grebes and Loons may not actually flock together, they have enough in common to make it proper to class them alike with "the submerged tenth;" and as my thought turns toward Loons, my personal acquaintance with them for over twenty years unfolds itself in picturesque panorama, in two main lines of association. One has to do with wooded lakes, and a great bird floating well out on the glassy surface, or exhibiting its marvellous powers of swimming and diving; the other brings up pictures of the sea. In one of these it is late autumn. I am lying flat on my face, peering over a ridge of sand, on the Massachusetts shore just below "Indian Hill," and watching a great Loon floating just off the beach, not twenty yards away, utterly unconscious of my presence. In another it is early winter, and I am strolling along the bluffs of Scituate. A number of Loons, with Ducks of several sorts, are fishing out at the beginning of a line of heavy breakers. A big comber is advancing. Surely it will overwhelm that Loon that floats quietly there in its course, facing approaching danger. Just as the wall of water reaches the bird, 


\section{Among the Water-Fowl}

the crest curls, and the avalanche descends. But that very instant the wary creature leaps at the intruder. The knife-like bill cleaves a way, and in a moment there rides the Loon safe on the other side.

Here is yet another picture. The cold, gray dawn of a November morning breaks over the misty, heaving sea. My boat is anchored quarter of a mile from shore. Very dim, as yet, appear the bluffs of Manomet, and below them the rocks, piled there by the 'Titanic forces of the winters' gales. From the north comes the bellow of the whistlingbuoy off "the Gurnet," at the entrance of old Plymouth harbour. The fishermen, one by one, are rowing out past in their dories to haul their lobster-pots and to fish for cod, every hail of theirs made audible by the megaphone of the mist. The gunners, too, are taking their station in the line that custom decrees shall begin at "the gunningrock," and the plunge of anchors and the rattling of chains is heard. Presently the whistling of wings makes me look up, to see gray forms that rapidly pass into the haze. Soon there arises a series of wild, laughter-like cries, weird sounds indeed, yet fitting perfectly with the surroundings. Nearer they come, and nearer, but it seems like minutes before I see one, two, three great birds, with long necks widely outstretched, and feet extended rudderlike behind, rapidly advancing, a hundred feet above the water, straight toward the boat. If they come on, they are safe, for I have no desire to hurt them. But if they swerve and cross the line at another point, the peal of guns will ring out, and 


\section{The Submerged Tenth}

one, at least, of the Loons will cease its flight and fall to the water with tremendous force, while the survivors keep steadily on their way.

Lying there in the stern of the dory, tossed by the waves, and not over warm, it must be confessed, for hours I watch the Loons and other fowl come and go. Sometimes it is the big fellow, the Great Northern Loon, but rather oftener the smaller Redthroated species-whose throat, however, has now lost all trace of its summer redness. The shoemaker gunners have nicknamed it "the Pegging-awl Loon," from its siender, sharp bill. Though smaller than the great Loon, it is still a big bird. The former can laugh loud enough in its summer home on the lakes, but in the autumn flight, at any, rate, I think it is outdone by the "Pegging-awl." The latter goes farther to the north to breed than its relative, and if it is correspondingly noisy, the Arctic solitudes where it is found must be far from silent.

If this be a fairly good flight-day, Loons will probably pass within sight every ten minutes at least. Sometimes from three to six will follow one another some rods apart, at irregular intervals. Just as often they travel singly. If there is any difference in the general habits of the two kinds, I think that the "Pegging-awl" is the more apt to go in parties. If, too, he is the greater talker, we may award him the palm for sociability. But that they are both good company, I can testify.

In the calm of the early morning very likely there will be one or two large Loons riding over the swells, diving now and then after their finny 


\section{Among the WAter-Fowl}

breakfast. Like as not some greenhorn gunner will row after them; but I never saw a Loon thus caught. It may let him approach nearly within gunshot, when it will quietly sink out of sight, and after some moments rise quite a distance off. After a few repetitions of this it will dive, to be seen no more.

If there is a strong wind, and the sea or lake is rough, I have found it not so difficult to approach them, especially in a sail-boat. Well do I remember, sailing in a catboat on Lake Assowompsett one cloudy, blustering November day when the chop was considerable, how we suddenly almost ran down a Red-throated Loon. The bird was so startled that it lost its presence of mind, and, instead of diving, flew. The boat was going directly before the wind, so the Loon had to rise directly toward the boat, almost striking the sail, and going so low over the deck that the possibility was suggested of seizing one of the dangling legs.

Usually, though, a Loon can seldom be forced to fly, even when it has very limited space for diving. Here is a typical instance to the point. One perfectly calm day in October a friend and myself noticed a large Loon out on Lake Nippenickett, and we decided to give it a chase, and see how it would act. We soon found that its main plan was to keep out in the widest part of the lake and avoid being driven in to the shore. It varied its tactics, too, apparently with the direct intention of deceiving us. Sometimes, after diving, it would emerge straight beyond us, sometimes off to one 


\section{The Submerged Tenth}

side, or even behind us, having swum toward us and gone under the boat. Once, when we succeeded in driving it into a cove, finding itself close to shore, it turned, and, swimming under us, was out in the open water again, ready for

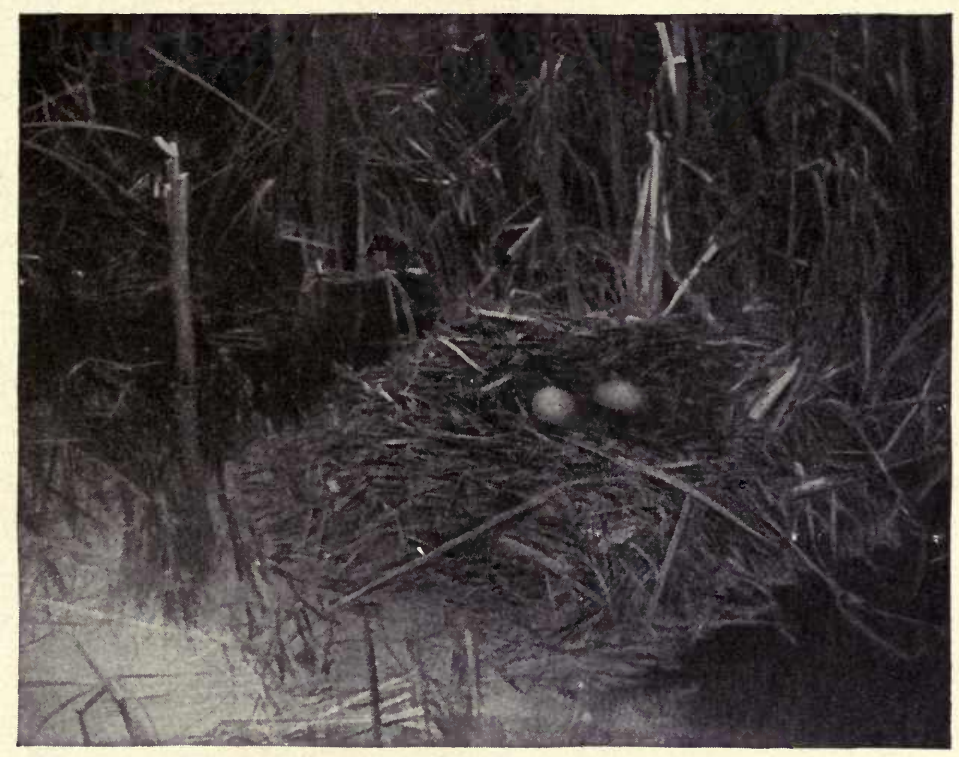

FLOATING NEST OF GREAT LOON, NEAR SHORE OF POND, MAINE. BY A. C. BENT

another chase. Sagacious bird! - who ever invented that phrase, "crazy as a loon?" The only excuse is that the bird's notes resemble wild laughter.

The small Loon is not known to nest in the United States, but in many places along our northern border the larger one makes its summer home on the wild lakes. In northern New 
England it is common. and now and then it breeds as far south as Massachusetts. Sailing about in Buzzards Bay early one July, I passed a Loon along the Falmouth shore, that was swimming with a half-grown young one close beside her. She seemed very fond of it, and kept caressing it with her bill with true maternal tenderness. Far was it from my thought to disturb them, and our sloop sped on.

Of all the places where I have observed the great Loon in its haunts, give me the Turtle Mountains of North Dakota. On those frosty nights of middle June, as we lay under our light cotton tent, snuggled up in heavy blankets, often when I was awake I could hear that wild, laughterlike cry - "ha-ha-ha-ha-ha-a-a" - as the Loons flew over from one lake to another. Our camp was near Gordon Lake, a fine body of water several miles around, with stony shores and a border of reeds. Out on its surface were always a number of Loons, and over on the west side several seemed to be patrolling parts of the shore. Walking entirely around the lake, I vainly searched the whole margin for nests. I had reason to believe that the young were hatched, and, as there were no muskrat houses or floating mounds that I could discover, it is likely that the eggs were laid on the bare shore, so that no nest was then in evidence.

In one place I surmised that the young were hidden amorfg the reeds. There the parents gave me a most interesting spectacle. The pair were patrolling, rather anxiously, about a gunshot off shore. Knowing of the curiosity of the Loon, I 


\section{The Submerged Tenth}

kept low in the reeds, and now and then waved my handkerchief above them. The Loons at once began to watch, and then gradually to swim in, until they were within twenty yards of me. They swam back and forth in front of me, keeping close together, their snowy breasts and steel-blue necks

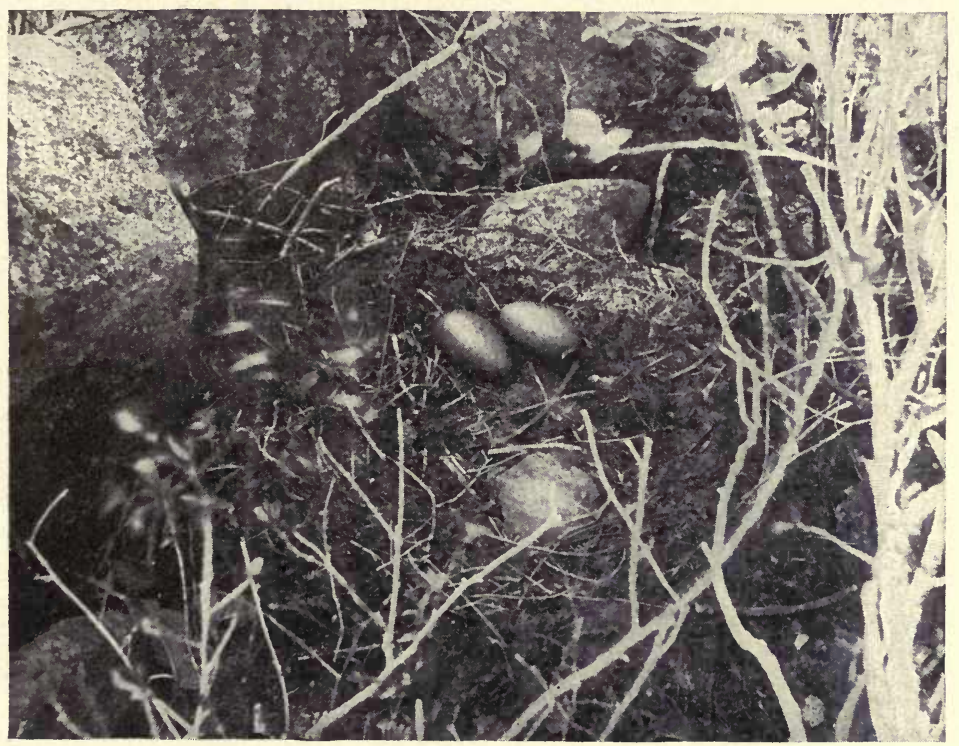

ANOTHER NEST OF THE GREAT LOON ON DRY STONY SHORE OF SMALL ISLAND IN LAKE-MAINE. BY A. C. BENT

reflected upon the mirror-surface, just beyond the reflection of the reeds and of the poplar forest. It was one of the memorable bird-sights of my life.

Anxious as I was to see the nest of the Loon, the account given by a settler of a small lake two miles beyond the camp, where a pair of Loons were always to be seen, aroused my enthusiasm. The next day, June 15 , was ushered in by a furious 
easterly storm, the rain descending in a perfect deluge, beating and driving, threatening to drown us out of camp. But for all that I donned waterproof and rubber-boots, and started for the new lake. The very first sight that greeted me, as I reached it, was a Loon off on the water. That only one was in sight gave promise of the other still being on the nest. This lake was less than half of a mile in diameter, and the task of examining every foot of the margin was by no means an

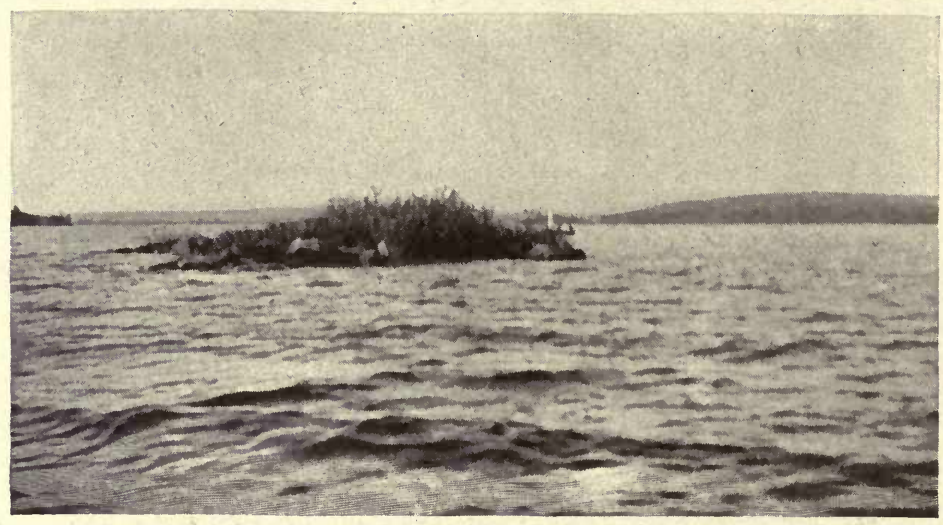

THE ISLAND ON WHICH THE PRECEDING LOON'S NEST WAS SITUATED BY A. C. BENT

impossible one, though it was more boggy, and there were more reeds, than usual. Impeded by my coat, I floundered on, the Loon following, keeping abreast of me wherever I went. The pond was in two parts, divided by a low island, that almost filled the narrows in the middle.

I traversed the eastern lobe, but found no sign of the nest. Then I waded to the island, and systematically examined its shore. There were 


\section{The Submerged Tenth}

several empty nests of Holboell's Grebe scattered along. Finally I was almost back at the startingpoint, heated, bedraggled, and - well-nigh dis-

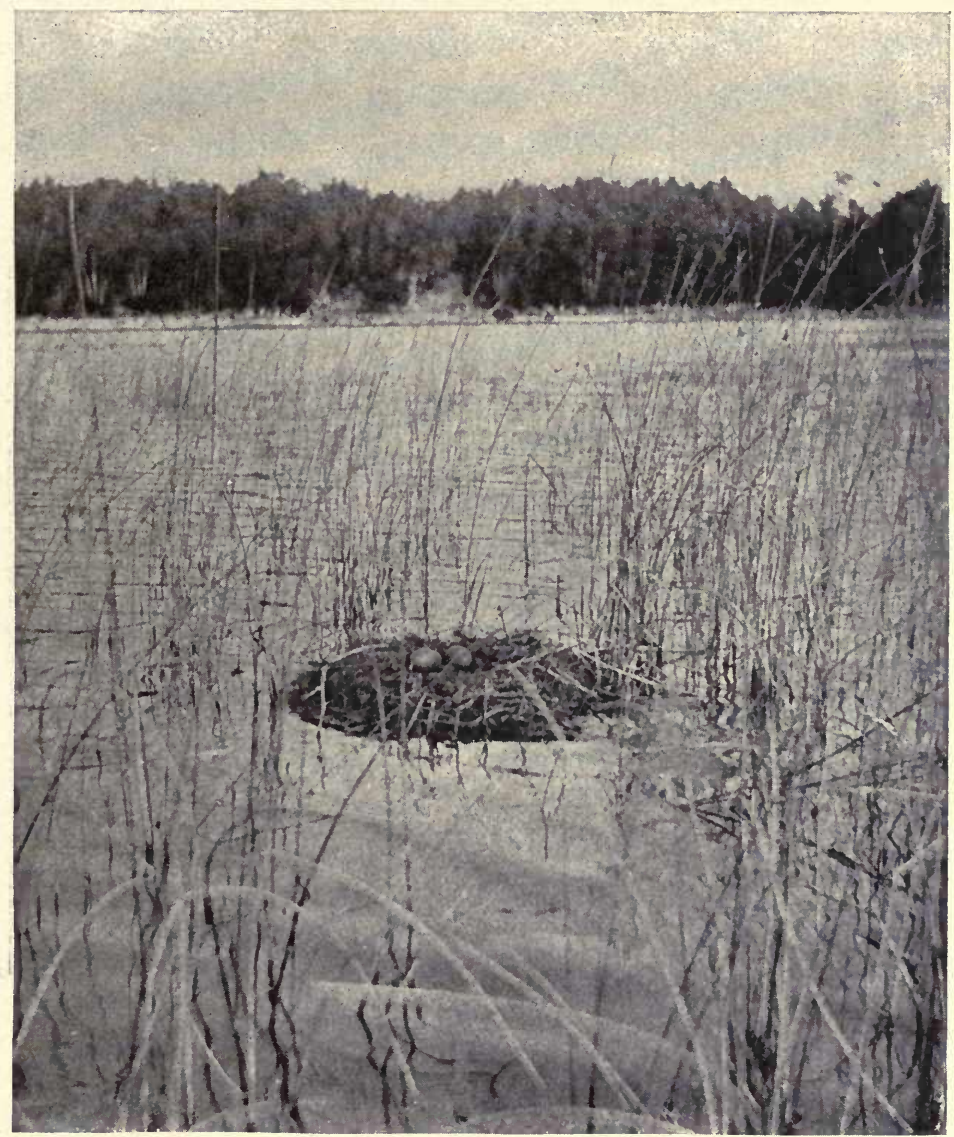

FLOATING NEST OF THE GREAT LOON, IN AN ONTARIO LAKE BY C. J. YOUNG

couraged. Suddenly, out at the edge of the reeds, about twenty yards ahead of me, there arose a most prodigious fluttering and splashing, and away went 


\section{Among the Water-Fowl}

an enormous Loon, half flying, half dragging herself over the water. Getting out into the lake, she alighted with a great splash, and instantly dove. Eagerly I hastened forward, and waded out. Through the reeds I could see a muskrat house, and I knew what was in store. Not on top, but on the outer side, well down near the water, the

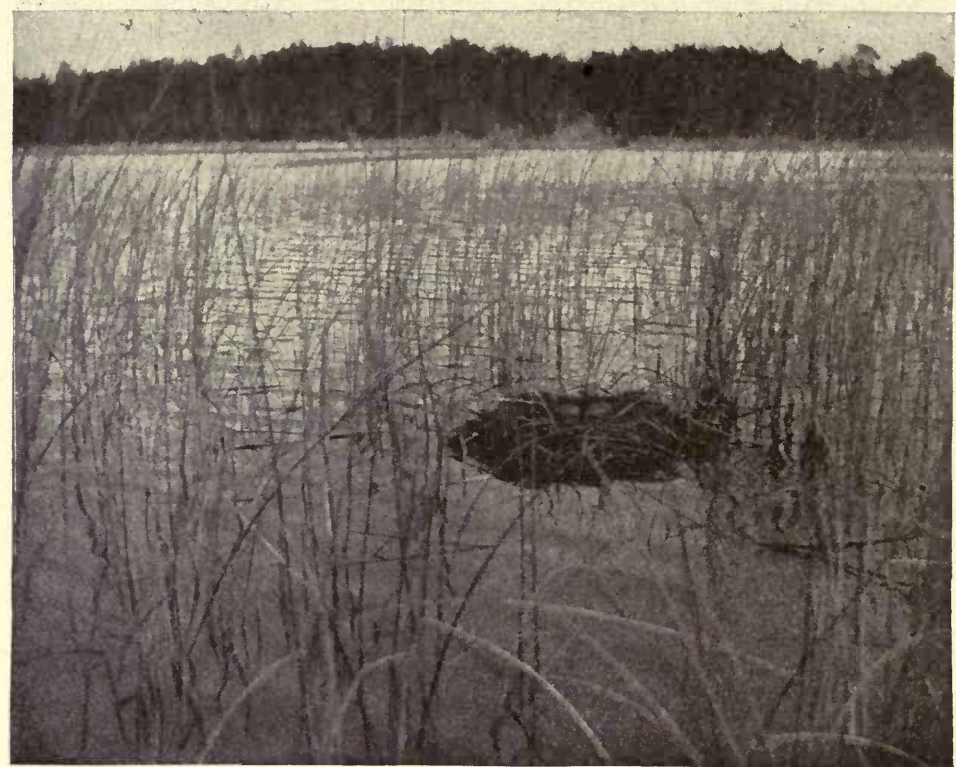

$\triangle N O T H E R$ VIEW OF THE PRECEDING

bird had flattened out a sort of platform. It was the home of the Loon-at last! In a slight hollow lay, not the usual two, but one enormous dark brown, spotted egg. That it was the full laying of the bird was evident, for it was almost ready to hatch. A day or two more, and I should have been too late. This it was, in particular, 


\section{The Submerged Tenth}

which made me confident that on the other lake the Loons had already hatched their young.

What could be wetter than the surroundings of this most amphibious creature, out there a couple of rods from shore in three or four feet of water, especially in that downpour, and with the lake rising so as almost to lap over on the egg! And there, up near the end of the lake, were both the Loons together, submerged, as usual-all but head and neck and a little strip of the back-engaged, no doubt, in family consultation. From them came now and then-it seemed to me rather inappropriately-the wild, quavering note, which, though it resembled a laugh, sprung from very different sentiments. I imitated the note, and they answered back. Whatever their meaning, my note was of genuine laughter, for I felt that the laugh was properly on my side. 


\section{PART II.}

\section{MODERN CLIFF-DWELLERS}

(Gannets, Gui.lemots, Auks, Puffins, Kittiwakes, Etc.)

ONE BY one, retiring like an army of heroes from a well-fought, but unequal battle, the Murres and their allies have yielded up fortress after fortress along our coast as the encroachments of man have

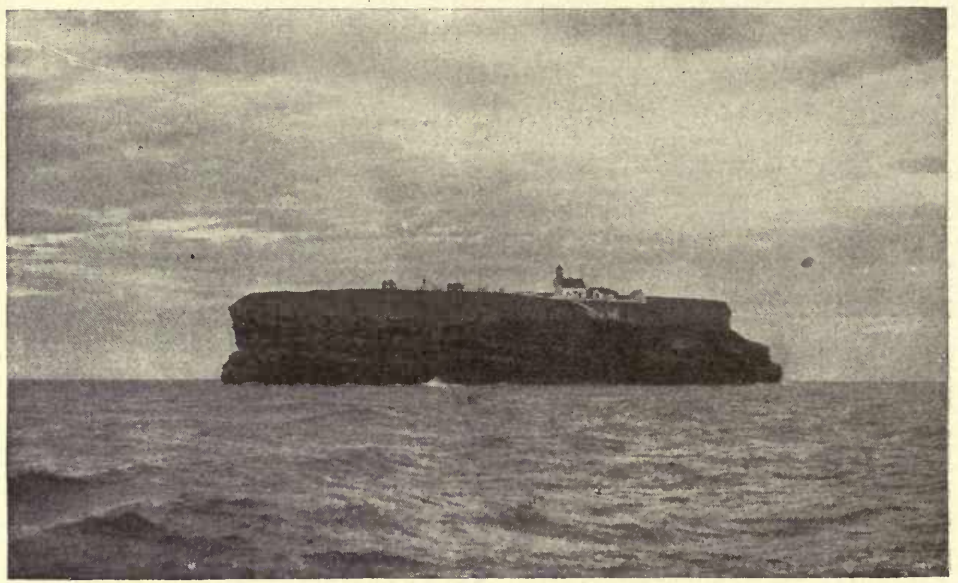

GREAT BIRD ROCK AT EVENING

pushed their breeding-grounds farther and farther toward the wilds of the north. The time was when they occupied the rocks off Boston harbour, and swarmed upon the islands of the New England coast. But this was long ago. Only the Black Guillemots maintain themselves as far south as the islands of the coast of Maine by hiding their eggs under forbidding boulders, as also do a very few 
Puffins at Matinicus Rock, and Razor-billed Auks at Grand Manan. Several pairs of Double-crested Cormorants, after many vain efforts to rear a single brood, are about giving up the struggle. I had hoped to find better conditions existing in Nova Scotia; but, wherever I went, the story was repeated that within the last few years the birds had ceased to nest.

Inquiry revealed the fact that the islands of the Gulf of St. Lawrence are now practically the southernmost stronghold of these interesting and elusive birds. So, in June, a year ago, I started for the Magdalen Islands, accompanied by a congenial bird-lover. A day's journey brought us to Pictou, Nova Scotia, whence we embarked in the weekly steamer upon the then calm waters of the often turbulent Gulf of St. Lawrence. Early next morning, exhilarated by the almost frosty air, we gazed upon the red sandstone cliffs, spruce-grown hills, and fields dotted with white cottages, of the Magdalen Islands, sparkling in the sunshine.

In due time we reached our destination, the home of a fisherman, near the eastern end of the chain of islands. After an interesting week spent among the water-birds of the ponds about East Point, the day arrived for our embarkation for the Bird Rocks. Weeks before we had made arrangements with the captain of a small schooner to land us on the Great Bird Rock on June 2 I, and call for us after four days, as well as with the keeper of the Bird Rock light for entertainment. 
The day was unpromising; clouds were threatening, a fog-bank hung off at sea, and the wind, strong from the south-east, covered the ocean expanse with white-caps. About ten o'clock, when we had given up hope of starting that day, the schooner was sighted off to the westward. In half an hour she had rounded the point and "hove to" off the beach. As no boat put off from her, we got two French fishermen to launch their seineboat and set us aboard. It was no easy matter, but finally we got out through the breakers without a wetting, and managed to tumble up on the plunging vessel.

Following along shore, for an hour or so, the strong wind bore us opposite East Point, when, turning our backs upon the grim expanse of sand that has received so many human corpses from the deep, we sped out into the unknown toward the invisible rock that lay sixteen miles to the north. Soon we approached the off-lying fog-bank, and the "gray walls" shut in thick and chill around us. The vessel was now rolling and plunging into the trough of the following seas in the most approved fashion. After two hours or more the captain thought that we must be getting near to the Rock. More and more birds came in sight, and we strained our ears for the clamour of the colony and the roaring of the surf. At length, anxious lest we should run too close upon the Rock in the fog, the captain crawled out and stood upon the end of the bowsprit, plunging almost into the sea. Suddenly, now, the fog began to lift - a sign of land. Soon we could see the blue overhead, and then, just as our look-out 
uttered a joyous shout, we saw an apparition of red and gray cliffs, and Bird Rock emerged from the mist like a grim fortress, less than half a mile away. On top of the precipice that rose sheer from the ocean were a light-house and other buildings; along its sides were lines of black and white that I knew were birds upon their nests.

Flying before the wind, the Rock seemed to rise right upon us. The air was now clear and the sur bright. Gannets, Kittiwakes, Murres, Auks and Puffins were passing and repassing about us, flying to and from the cliffs. Then we rounded the north-east corner of the Rock, about a gunshot out from it, looking up in amazement at the swarms of birds that almost filled the air, or clustered in masses upon the narrow ledges of the cliff. It seemed to me like a busy street of a great city, with its tall buildings, in and out of which the crowds surged, only that all the windows were doors, and it was rather alarming to see people falling in showers out of the tenth or twentieth-story windows. The words of the Psalmist came to me as impressively descriptive- "Who are these that fly as doves to their windows?"

Our approach was noted from the lighthouse above. The British ensign flying from the top of the flag-staff was dipped in our honour, and sharp rose the crash of the dynamite bomb salute. "Let go," came the shout from above, as we rounded the north-west corner. Down went our anchor in response. We both took snapshots of the cliff, then hurried into the dory, where our baggage had already been put, and were rowed shoreward. The 


\section{Among the Water-Fowl}

sea broke considerably around on the other side; but here, fortunately, where the only beach was, it was under lee from the wind, and without any difficulty we ran the boat up on the little strip of stony shingle only a few rods long.

On the left was a series of ladders spiked to the rock, by which one could climb up the over one hundred feet of cliff, and here by the boat was the famous "crate," a little open box or platform, with

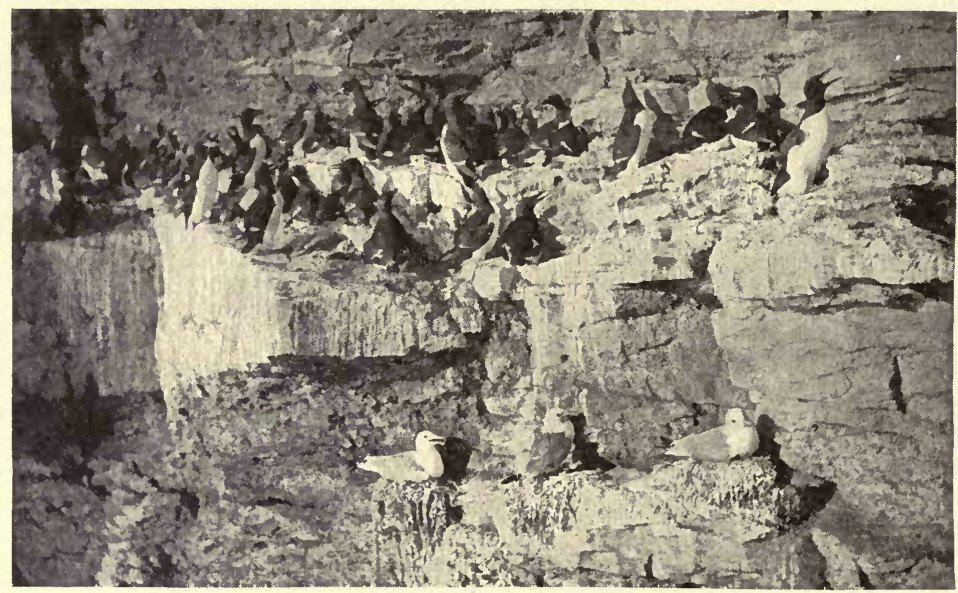

MURRES AND KITTIWAKES NESTING-FROM THE CRATE

slab sides about waist high. Into this we put our baggage and then climbed in ourselves. The crank above began to turn, and we swung clear of the ground. This was the ordeal which in time past I had somewhat dreaded, but which now seemed the pleasantest and most natural thing in the world. Before we realized it we were well up from the beach, which looked very small and far-away, when, at length, I ventured a downward glance, We 
were only some ten feet or so from the cliff, and passing close to the birds. First, if I remember rightly, were some Kittiwakes, each on a little nest of sea-weed, built very cleverly and securely on to some slight projection or niche of the cliff. Some of the occupants sat still, others stood up, revealing two spotted eggs, or, in a few cases, newly-hatched downy young, while one or two took to flight. Off on the left was a long array of great white Gannets, nesting on a ledge. Directly in front of us, a little higher up, we passed a great mass of Murres. On both sides were birds, anywhere and everywhere they could find a footing. Here and there a Razor-billed Auk peered out from a recess of the rock, watching our progress.

The crate was all the time turning around from the twisting of the cable, but so slowly that I did not mind it at all. The whole episode seemed like a dream, it was so soon over. In five minutes we rose in sight of the green-sward at the top, and saw two men and two women labouring at the crank, the latter with flushed faces. Then they swung the derrick-arm in over the land, where we got out to meet the keeper, Capt. Peter Bourque, who gave us a most royal welcome, and introduced us to the members of his family who were staying with him on the Rock at this time-a grown-up son, daughter and niece.

The sun was now bright, so my friend and I took our cameras and started forth to view this new world of bird-life. There was the schooner already sailing away, and North Bird Rock out beyond, nearly a mile to the westward, appearing as two 


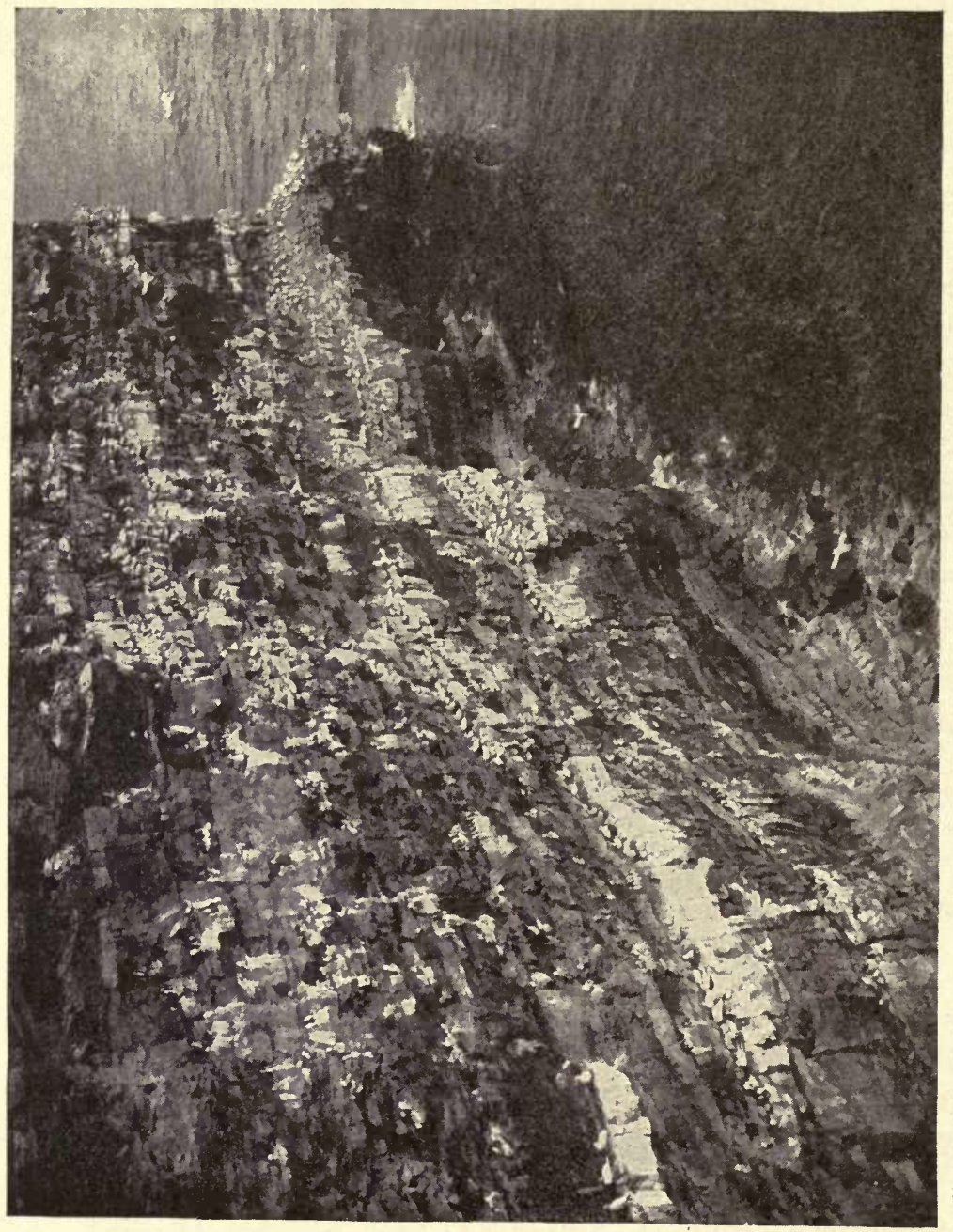

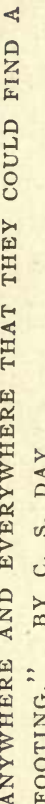

蛋

(ㄷ) 
separate crags, both of them white on top with brooding Gannets. Then we looked directly down over the edge of the cliff, and stood entranced at the sight. It was indeed one of life and motion, for a throng of birds filled the air, ceaselessly passing and repassing. Some were leaving their nests, to scale down and out over the water. Others swung up from the ocean level, to alight each in its proper niche. Others passed by us within a few feet, but none flew over the land. Years ago the

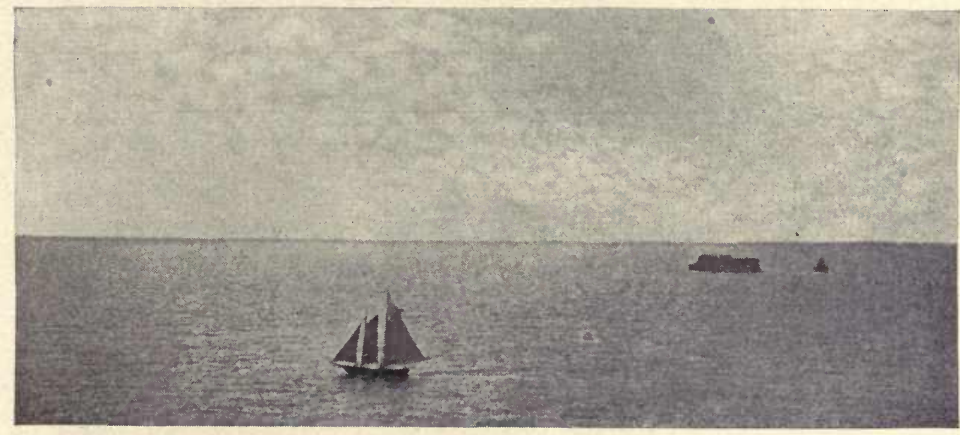

"THERE WAS THE SCHOONER ALREADY SAILING AWAY, AND NORTH BIRD ROCK OUT BEYOND",

birds occupied the whole level area of green-sward on top, which I should think is about three hundred yards long, and half as wide. Now, however, since the building of the lighthouse, they recognize the fact that man has the ascendency.

There was no cessation in the passing throng, any more than there is in business hours on the principal street of a large city. It was a constant habit for birds to act as though they were about to alight, hovering slightly as they passed some convenient crag, even extending their feet, but decide 


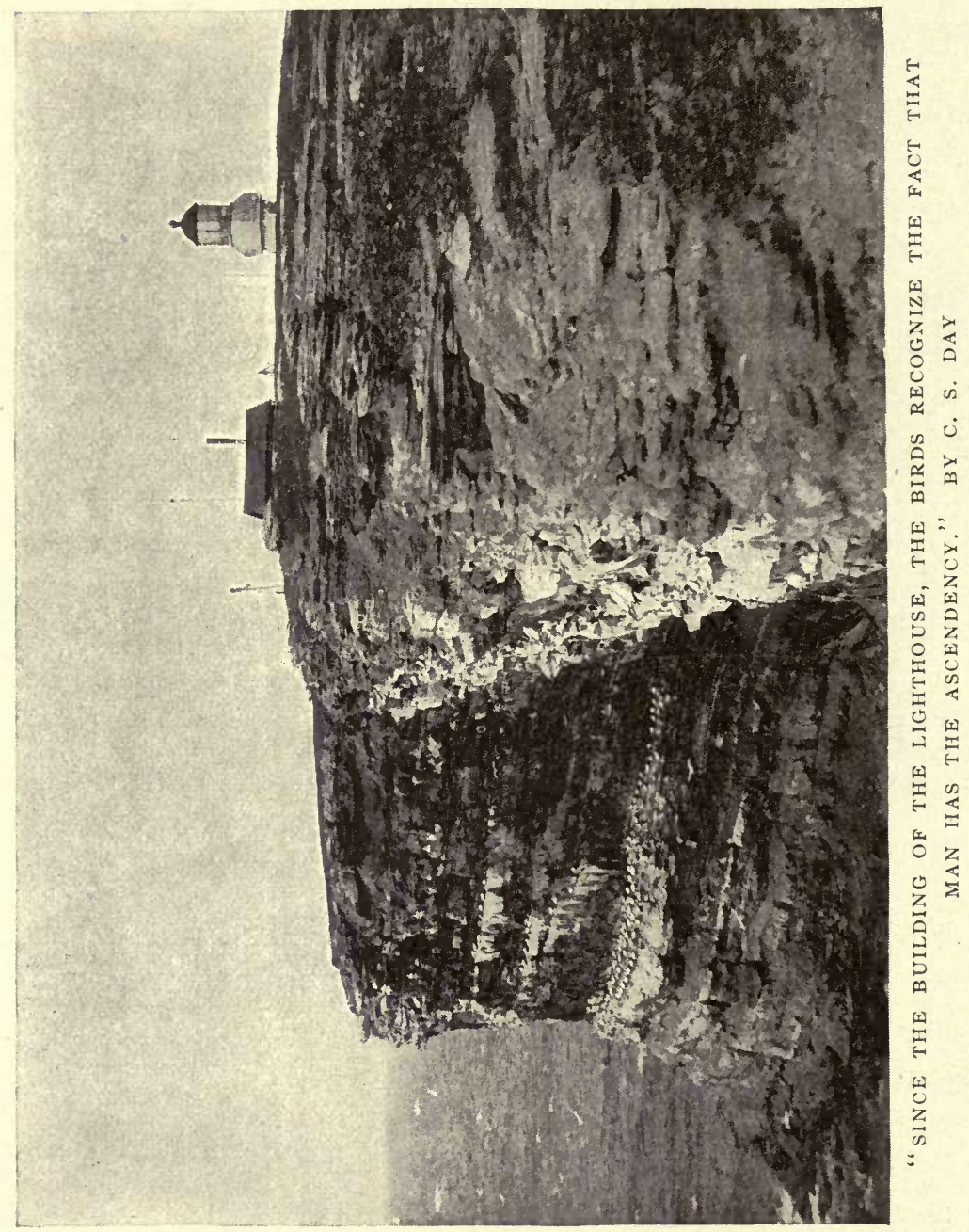


to pass on, and scale down again and out over the ocean. No bird seems ever to turn back and alight. It appears to be a sort of social requirement, in this bird-city, never to alight, except after the conventional circuit out over the water. Puffins, Murres and Razor-bills often gathered in groups on the rocks at the top of the cliff, but always at the very edge. They were not shy, and would let one approach within about twenty feet before taking to flight. Now and then a Gannet would perch at the top, but not for long, and it was still rarer to see a $\mathrm{Kittiwake}$ in such a position. Both these species, for the most part, nested well

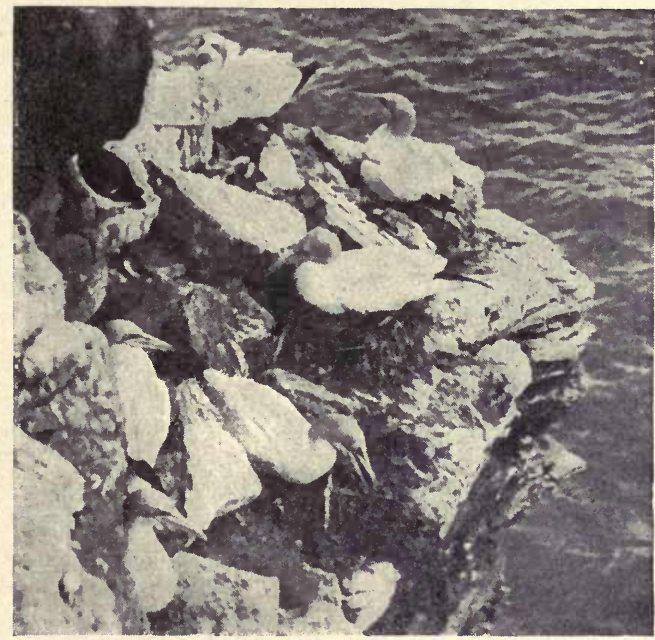

"I SOON NOTICED A GROUP OF GANNETS ONLY ABOUT FIFTEEN FEET DOWN"

down from the top, but I soon noticed a group of Gannets only about fifteen feet down, and this was one of the first subjects for the camera. A single one, quite approachable both as to disposition and location, had a nest even nearer the top.

It seemed impossible not to follow the birds with the eye, and the result at first was to produce slight dizziness and headache, almost "sea-sickness." And then, too, until one gets accustomed to it, 
it is a strain upon the nerves to be ever on guard against taking a single careless step and falling off the cliff. The birds seemed so wonderfully at ease, launching off into space, that, after watching them awhile, it seemed almost natural and proper to follow their example.

At length, in our tour of investigation, we came

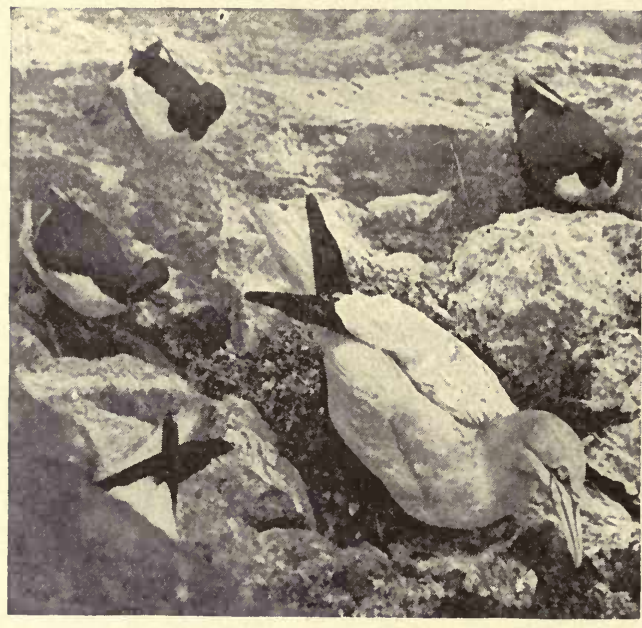

GANNET AND BRÜNNICH'S MURRES INCUBATING, AS SEEN FROM ABOVE around to the south-east end of the island, where the Puffins breed. The ground here was rather less grassy, rough, with rock cropping out. Here and there were holes in the ground, the entrances to the burrows of the Puffins, which most often led in under some flat rock. Groups of Puffins were congregated upon several projecting rocks at the edge of the cliff, and now and then an incubating bird would scurry out from a hole, as we approached, and fly off. Here the cliff was broken into a series of comparatively broad ledges, which one could rear.h successively by several iron ladders. It did not seem as formidable as on the other side, and we both made the descent to the lowest ledge, about fifteen or twenty feet above the water. 
Now and then we started an Auk from its egg in some recess or under some projection of the rock. As this was the most accessible part of the cliff, many eggs had been gathered from these ledges, and there were not as many here as elsewhere, where they could not be reached. However, as we climbed down to the bottom ledge, we came upon a fine crowded line of Murres, each sitting on its single egg laid on the bare rock, close in under the overhanging cliff. They all left their eggs pell-mell when they saw that we were really coming down to them. The suddenness with which they flew

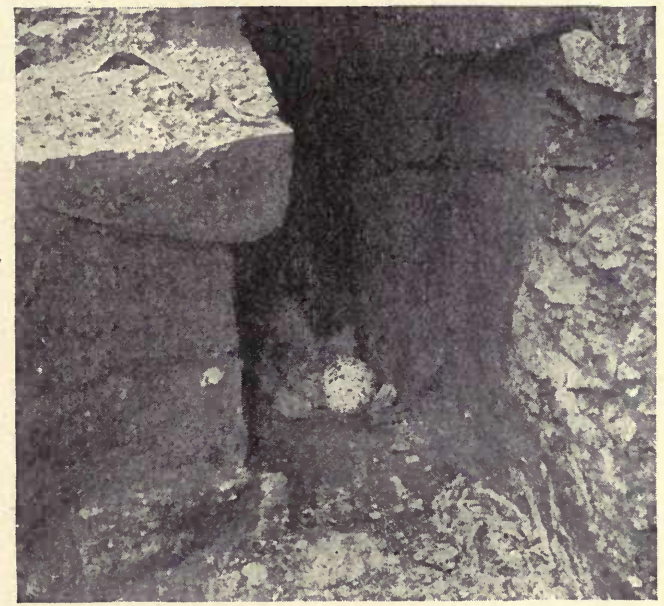

"NOW AND THEN WE STARTED AN AUK FROM ITS EGG IN SOME RECESS . . . OF THE ROCK"

started one or two of the eggs rolling, and then I sav a practical illustration of the wisdom of the plan of Nature which has made the eggs of these birds pear-shaped. Instead of rolling off the ledge, they simply turned around on their axis, only moving a few inches from their place. The shells, too, are so hard that they can withstand a great deal of rough usage, though occasionally I noticed one that had been broken.

After inspecting these interesting sights, we 
climbed back to the top. My friend went off with his camera, and the Keeper came along, offering to pilot me about, taking me to the north side, the highest part of the island. Here was another descent by ladder, and the invitation was given me to go down to a fine Gannet colony. I accepted it, and followed my guide, not without considerable trepidation, down two ladders, about half way down

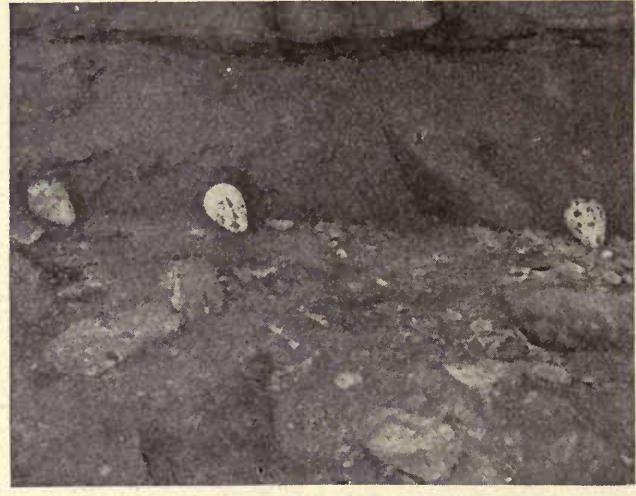

" A LINE OF MURRES EACH SITTiNG ON ITS SINGLE EGG LAID ON THE BARE ROCK, CLOSE IN UNDER THE OVERHANGING CLIFF" the precipice. Here it was necessary to walk along a narrow ledge, barely wide enough for one's feet, for about fifty yards ere we could reach a broad, safe promontory at the corner of the island. At first it seemed like courting a violent death to follow that strait and narrow way along the verge of destruction; but assured by the Keeper, and steadying myself by his big, brawny fist held out behind him, I passed safely through the ordeal, and breathed more freely when we reached the projection, where we could view two sides of the cliff.

Upon the continuation of the same ledge, around the corner, was a splendid array of Gannets upon their nests. The nearest were only about ten 


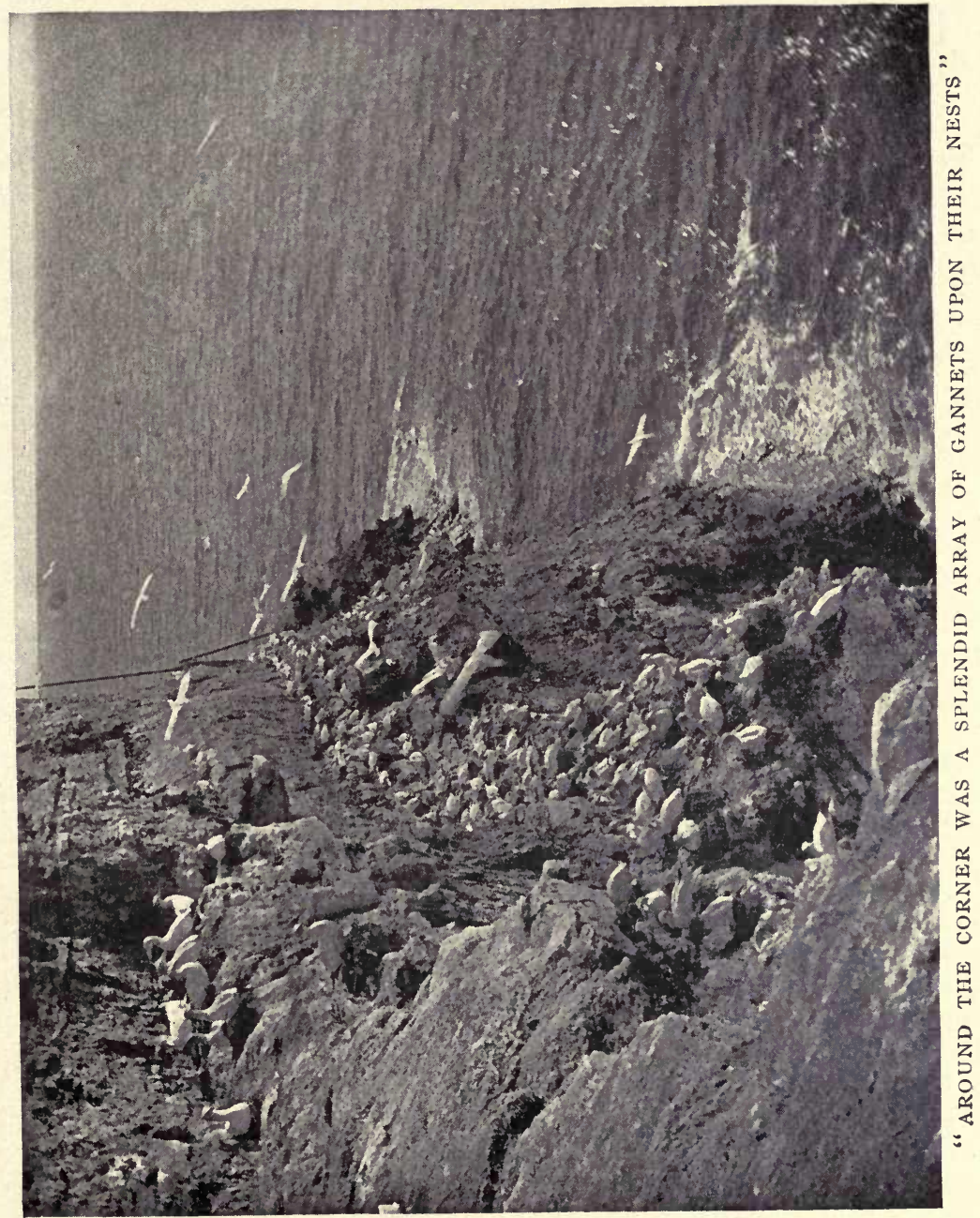


feet off. A few of them flew, as I crawled out to their nests, but the rest sat indifferent, knowing that the ledge sloped so much that no man would have the hardihood to reach them. The great creatures were going and coming, some of them bringing bunches of sea-weed in their bills to repair their nests, perhaps pillaged of material by their neighbours. Each had its single very large dirty white egg, usually in a fair snug nest of weed, but occasionally the egg was upon the bare rock. Probably the lining was to be added later.

After supper I arranged quarters in the cellar for developing plates, and went to work on those I had exposed during the afternoon. As the darkness gathered, even there indoors, I could hear one sort of bird-note, all the other members of the colony having apparently relapsed into silence and slumber for the night. It was a funny little twittering or chattering, that seemed to come from all directions, and I recognized, from descriptions, the song-it almost deserves that name-of the Leach's Petrel. They evidently were flying about, and, after my work was done, I went out to investigate. It was pitch dark, however, and I could see nothing of them, so I retired to secure needed rest. All night, in dream, I seemed to be crawling out on dangerous ledges after birds, and trying to save myself from falling.

We were up early the next morning, and out before breakfast for a look at the birds. The weather was cloudy and windy, though there was 
no fog-evidently no chance for photography. Breakfast was over by seven, and then it did not take long to return to the birds. It seemed very strange to have so many of them so close about us, and these not the common door-yard species, but those which usually one must seek afar upon the wild seas. For all that they made the most agreeable and fascinating of bird-neighbours. I had expected that Bird Rock would be a very noisy place, but in reality it did not give me that impression. During the day there are plenty of sounds, but they are either lost or mellowed in the vastness of Nature's amphitheatre. The sea moans and the wind sighs, making a sort of bass monotone into which the cries of the birds harmoniously blend. From the house it all sounds like some muffled murmur. But standing at the edge of the cliff, the sounds are audible enough, though not as earsplitting as in some Gull or Tern colonies. The loudest calls arose when anything agitated the Kittiwakes, when the shrill clarion-sounding like " kíttiwake, kíttiwake" - enunciated with startling distinctness, rang out above everything else. The harsh grating notes of the Gannets were also very noticeable at times. But the other inhabitants have very subdued voices, and only-express themselves in low croakings and gruntings.

The morning passed pleasantly and profitably in further study of the birds, especially the Murres. There were two kinds, the Common and the Brünnich's, in about equal abundance, I thought. The two were mixed in on the ledges indiscriminately. A Common Murre sitting on its egg was just as 
likely to have for its next neighbour one of the other species as an individual of its own kind. Occasionally all on a ledge would prove to be of one species only, and often, when mixed, one kind would greatly outnumber the other. But the only way to get identified eggs was to watch a ledge, note the order of the species as they sat upon the eggs, and then mark the eggs as they were taken. In addition to the above, there are a few individuals of the type once named the "Ringed Murre," distinguished by a white line running back from behind the eye. Naturalists are in doubt as to whether or not this is a valid species, and, if not, how to account for this aberration.

We also investigated the nesting of the Puffins. Securing a pick-axe, by hard toil we managed to dig out several burrows. Each was from one to two yards in length, ending in a larger chamber, where the one dirty-white egg was laid in a slight bed of grass and feathers. The soil is largely the debris of red sandstone, which, we found, gives to some of the eggs a reddish stain rather hard to remove. In one instance we caught a Puffin on the nest. Despite its struggles and biting, the Keeper's son despatched it, and the work of taxidermy fell to my lot, which occupied the remaining time before dinner.

About this time, as I had hoped, the clouds rolled away, and we were favoured with an afternoon of sunshine. Of course the camera came again into vogue. After taking some more general views, I began the attempt to photograph birds on the rocks at close range. The south-east end Puffin 


\section{Modern Cliff-Dwlilers}

ground seemed to be the best place for this, where Puffins, Murres and Auks gathered at the top of the

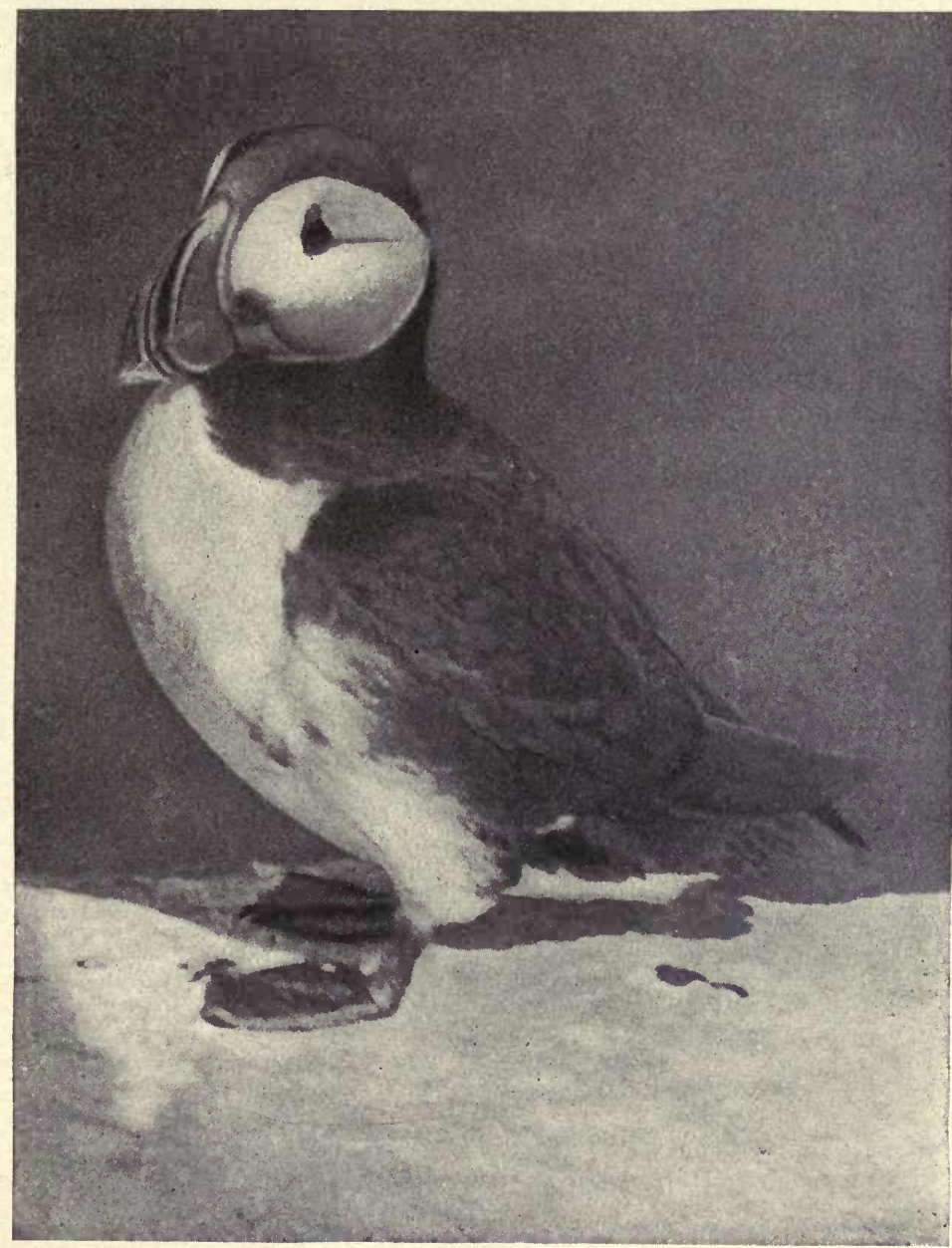

"PRESENTLY A PUFFin ALIT RIGHT in FRONT OF. THE CAMERA"

cliff. First I noticed one rock where the Puffins frequently alit, and set the camera on the ground, focusing it on this spot. Then I withdrew with 


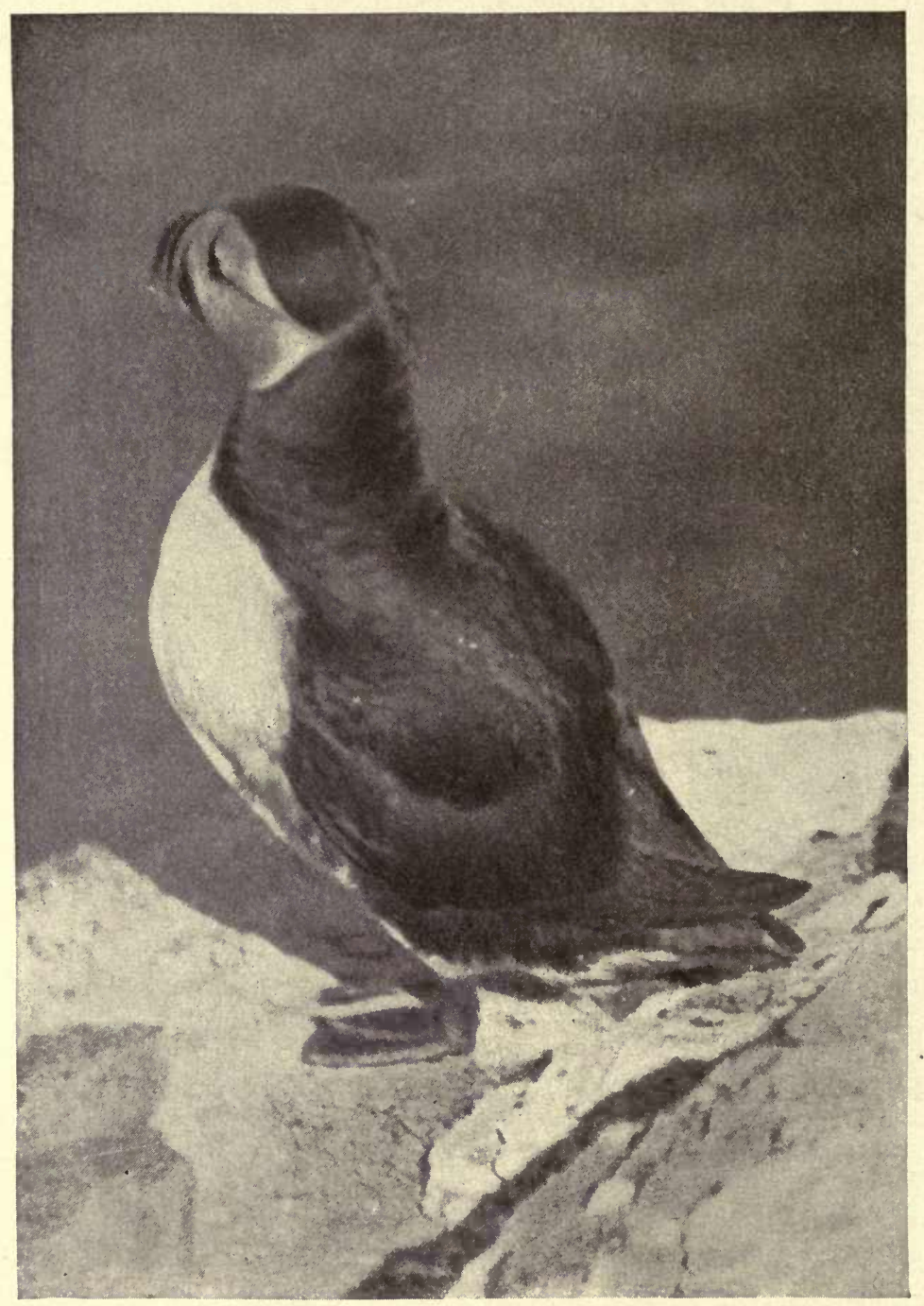

"I MADE SEveral EXpostres on piffins" 
the end of the long tube, and lay down on the ground, fifty feet away. Presently a Puffin alit right in front of the camera, then another. I made several exposures on Puffins, then removed the instrument to another rock, where I secured some close shots at Murres and Auks. After that I

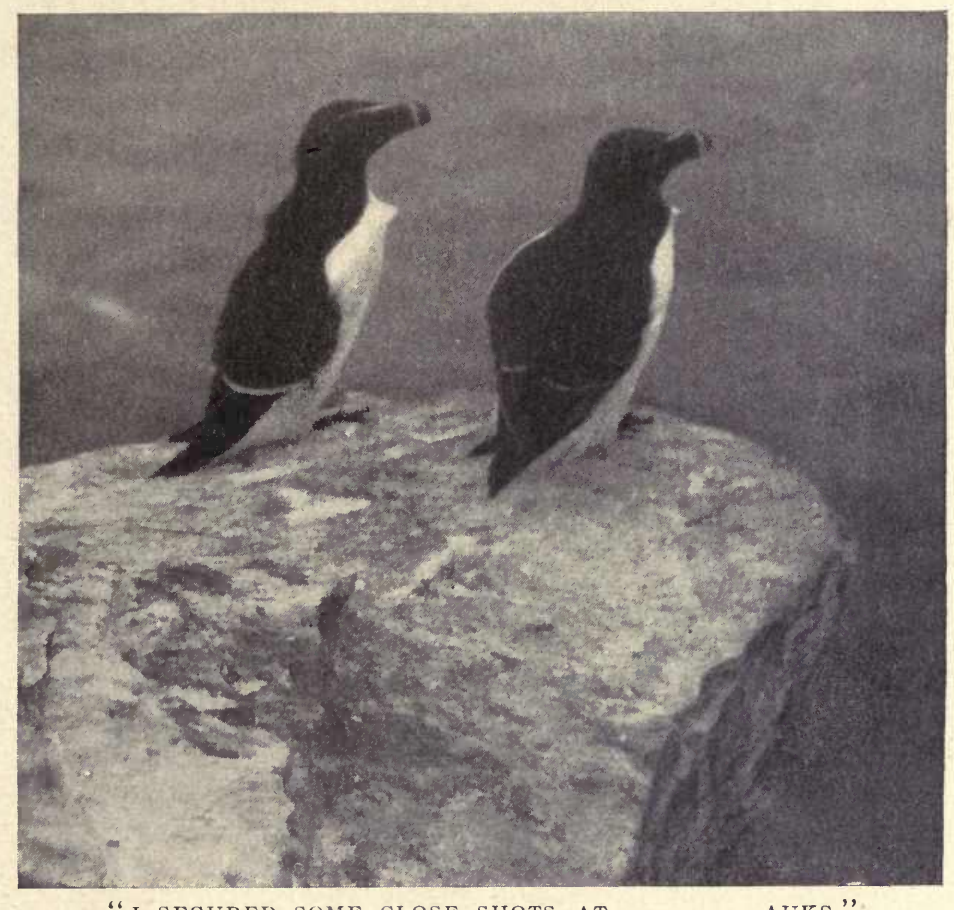

aimed at a whole crag on which all these birds gathered in a larger group, and made several exposures on them. They had to be rapid exposures, as the birds were moving their heads all the time, and the strong wind blew their feathers badly.

I was interested in watching the Gannets in their relations one with the other, and it seemed to me 
that they were the most quarrelsome of all the CliffDwellers, though for the most part they were peaceable enough. At times I saw groups of them huddled together in friendly fashion, some of them, probably mates, caressing one another with their

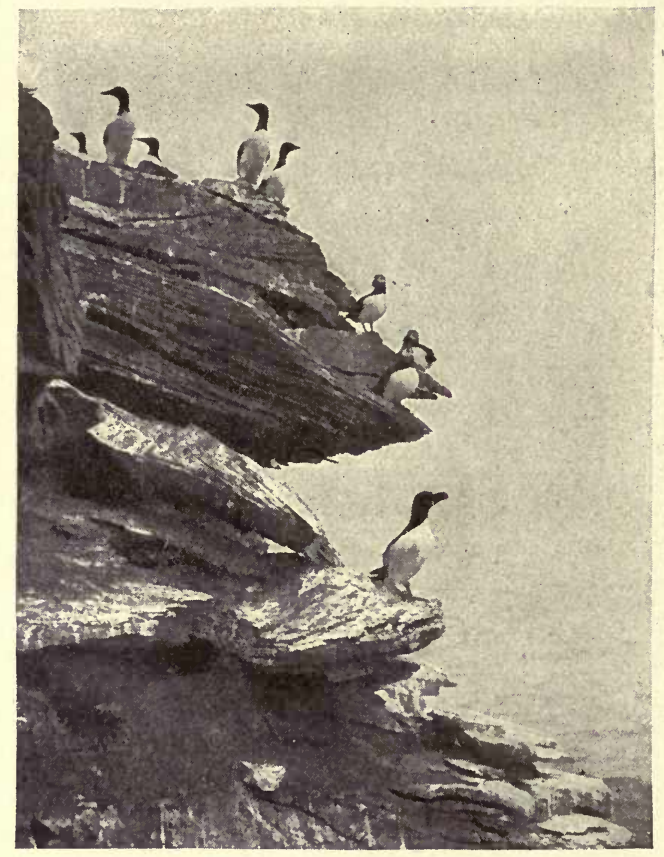

AFTER THAT I AIMED AT A WHOLE CRAG ON WHICH ALL THESE BIRDS GATHERED IN A LARGER GROUP" bills. Yet frequently there were manifestations of displeasure and hostility. One instance was especially curious. I saw a Gannet plunge into the water from mid-air, and come to the surface with a fish or eel. Another at once laid hold on the prize, and there followed a long tug of war. I pur posed seeing the a ffa ir through, but after ten minutes they seemed no nearer to a finish than at first, and something else distracted my attention. It is a splendid sight, of which I could never tire, to watch the great fellows scale close by the top of the cliff, with extended wings that measure as far across as a man can stretch, and then glide down and out over the ocean, at times to 
plunge like an arrow into the wave with a force that suggests concussion of the brain, disappearing for some seconds, and then fluttering up with the fish which is seldom agile enough to escape such an onslaught.

It was interesting to hear the Keeper tell about the birds. After the breeding-season they all scatter, and very few feathered creatures are seen during the long winter but files of hardy Ducks, like the Eiders, as they fly along the lanes in the drift-ice. What an experience it must be to remain isolated from the world, in all those bitter, fearful storms, beyond human help for months at a time! No wonder these brave and hardy people rejoice over the return of the birds in the spring. Records of this and other phenomena have been kept at the request of scientific societies or of the Government, and I will quote a little from the ledger. A record of temperature, by the way, is also kept, and other meteorological facts. The highest recorded temperature on the Rock was 73 degrees, Fahrenheit. During the daytimes of our stay the mercury indicated from 48 to 55 . Whoever visits the Bird Rocks, even in summer, should wear winter clothes and not forget a heavy overcoat.

Here is a calendar of the arrivals of the birds in the season of r 900-as the Keeper had it :

March I4. I dozen Kittiwakes

" $15 . \quad 2$ dozen Kittiwakes

" I6. Ioo Kittiwakes

“ I8. 500 Kittiwakes. Disappear for a few days

“ 22. 1000 Kittiwakes 


\section{Among the Water-Fowl}

March 27. Kittiwakes all back

“ 28. About 2000 Murres appear, and depart

April 2. About Iooo Murres return. 2 Gannets seen

“ 3. Murres all arrived

“ 4. 4 Gannets seen

“9. Gannets common

“ I I. 50 Razor-bills return

"18. Razor-bills common

“2 2 . 6 Puffins seen

“28. Puffins common

“ 29. Petrels heard

May 2. Petrels common

The following is the record as kept for 1895 , in accordance with a printed list of questions:

Kittiwakes. Arrived March I I

“ Next seen March 23

“ Common March 24

،

Murres.

Began to lay May 23

“

Arrived March 25

Next seen April 3

" Common April 3

“ Began to lay May i 5

Gannets. Arrived April I

" Common April 12

“ Began to lay May 5

Razor-bills. Arrived April I 8

" Common April I 8

" Began to lay May 24

Puffins. Arrived April 26

“ Common April 26

“ Began to lay May 26 
Petrels.

Arrived May 6

" Common May 6

“ Began to lay May 29

Saturday, the 23 rd of June, dawned clear and calm. After breakfast we started out on a trip to North Bird Rock, as the sea was smooth, and all conditions favourable. The other men lowered me, in charge of the cameras and various equipments, in the crate, and then climbed down the long ladder. There was a dory up on one of the lower ledges, out of the reach of any ordinary sea. They manage this very nicely by attaching the hoisting apparatus, thus easily swinging it up or down. The Keeper and his son rowed. As we neared the rocks, the Gannets, far wilder than on the main rock where they have become accustomed to the presence of man, began to fly off in clouds, and I took a couple of snapshots, which, owing to the plunging of the boat, were not very successful. The rock is in two parts. The main part, occupying hardly more than an acre of space, begins with a few low ledges, then rises up precipitous about forty feet. The top was covered white with Gannets on their nests, as was the other part, a most interesting formation. This is called the "Pillar," or "Pinnacle," consisting of a perpendicular column of rock rising sheer out of the water some sixty or seventy feet, and, I should think, absolutely unclimbable.

There is no beach to these rocks, and the sea, comparatively calm as it was, rushed upon the ledges with considerable violence. Awaiting a good chance, we ran our boat on to a flat rock and jumped out. First we both took pictures of the 


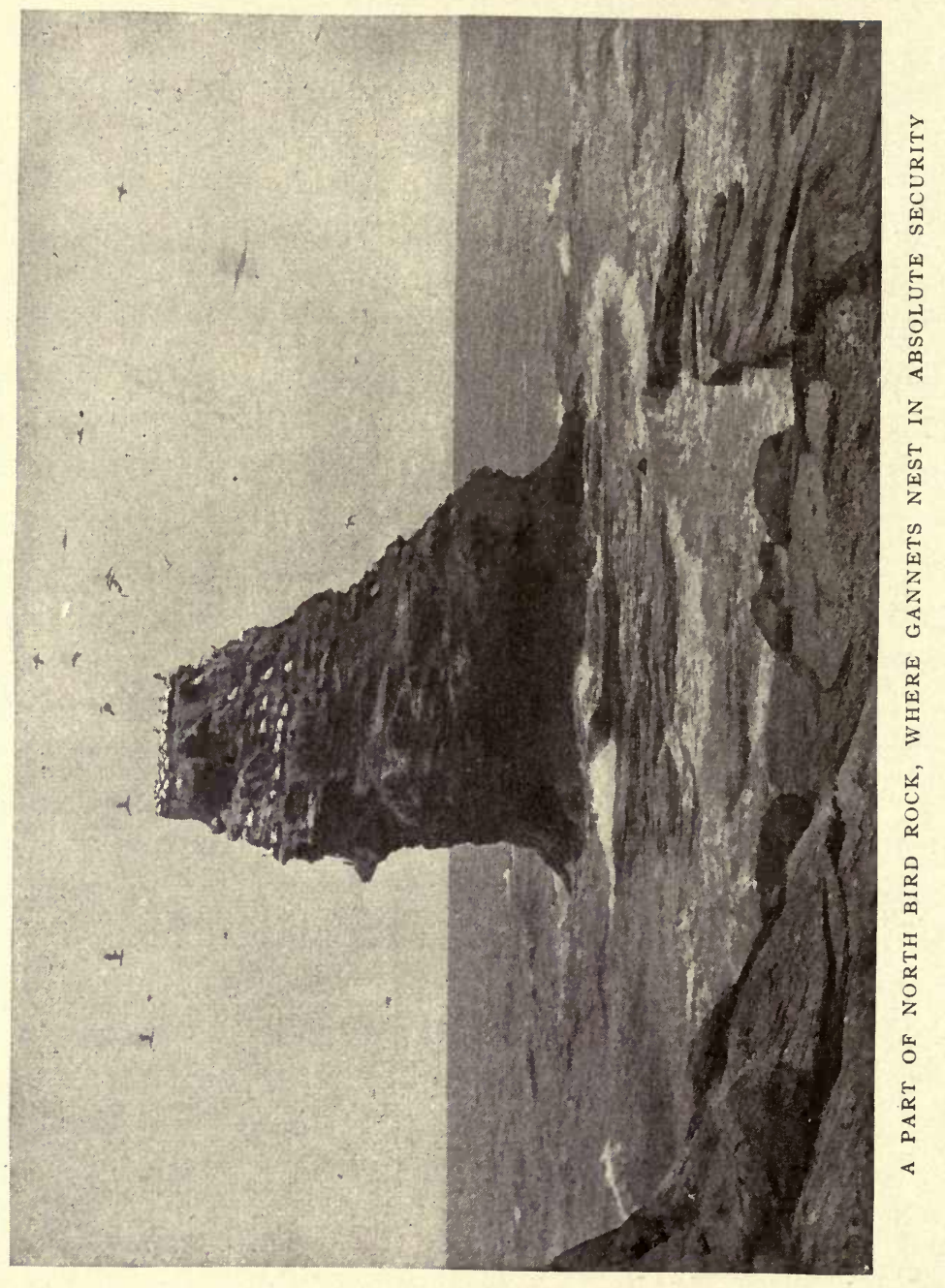


Pinnacle, that stood about a hundred yards off, with shallow water intervening. Then we undertook to scale the cliff. Kittiwakes had nests here and there on the sides, a few of them within reach by a little climbing. Fortunately there were ledges and projections not far apart. We let young Bourque climb up first, using my shoulders for a ladder, and had him pull us up. Thus we reached ledge after ledge, until we were safely landed on the top. This we found to consist of bare flat rock, which was covered with nests of the Gannets about a yard apart all over the area. They were piles

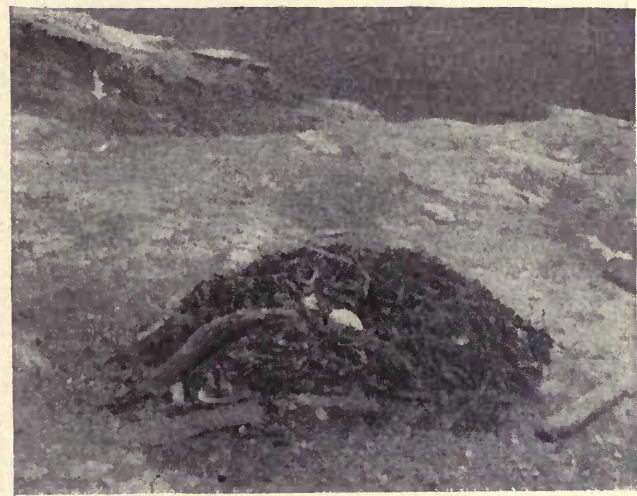

"I SELECTED ONE OF THE [GANNETS'] NESTS TO PHOTOGRAPH, A GOOD LARGE ONE WITH AN EGG IN IT AND A SIZABLE FISH LAID UP ON THE EDGE" of sea-weed, more or less bulky, and most of them were empty. Later in the day we learned the cause.

I selected one of the nests to photograph, a good large one with an egg in it and a sizable fish laid up on the edge for future use. Just then the Keeper called out, from below-"Gentlemen, we must leave; there's a squall coming!" Looking toward the west and north, I saw a threatening haze and an evident line of wind, shown by a whitened sea. I hurried so that I spoiled one plate, but I got the nest taken, and then, without stopping 
to examine further, we made the descent, lowering one another from ledge to ledge. I told the anxious Keeper that I must have five minutes more, and rushed around to the other side of the island, where I could see what I named "the Rift." It was as though the island had at some time cracked apart, leaving an opening a few rods across, with perpendicular sides that furnished nesting-places for a number of Kittiwakes. I do not remember seeing any Murres or Razor-bills, though there may have been a few on the sides not examined. The sea evidently washes through this rift at times, though now one could walk across. I got time for one picture of it, and another of the Pinnacle, before the Keeper protested that I must come, and fairly dragged me into the boat. The wind was rising and the sea increasing. We got back to Great Bird Rock, however, before the squall finally came. Then the wind blew quite hard and the rain poured down for some time, when it cleared again, giving us a beautiful calm, sunny afternoon.

I spent the first part of the afternoon getting pictures of various birds by setting the camera on the rocks where they alit, with the tube attached. Later I went down with the Keeper again to the Gannet colony on the ledge at the north-west corner, and did some photography, as on the first visit I did not take the camera. Returning to the top, the Keeper tied a rope under my arms, and held it while I climbed down to a ledge near the top where a number of Murres were nesting, and secured a few identified eggs of both species, 
having previously made a record of the species of the birds in order, as they sat on the eggs.

One of the most interesting episodes during our stay was the descent in the crate to photograph the birds nesting on the adjacent wall of the cliff. This west side of the island was under the full glare of the afternoon sun, splendid for instantaneous exposures. I got into the crate, with plenty of plates, and was swung out and lowered, until I gave the signal to stop. All about were many interesting subjects, especially Kittiwakes, that I had found no opportunity to photograph before, also groups of Murres, and off to one

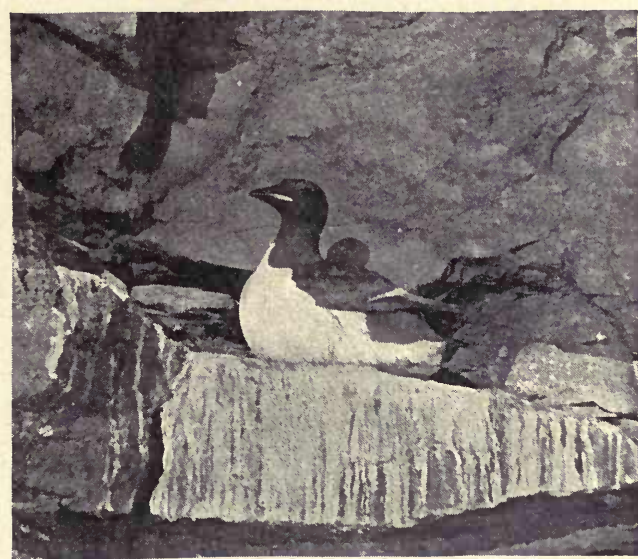

AN INCUBATING BRÜNNICH'S MURRE side some fine Gannet ledges, with long arrays of the great, snowy birds. The best subject was a mass of Murres of both kinds on their eggs, and just below them three Kittiwakes on their nests. They were all within ten feet of the course of the crate. When it was stopped opposite some good subject I held the camera on the little railing and got the exact focus of the birds, which did not appear to mind my presence particularly, though they kept uttering their notes, and now and then one would leave, though it soon returned. Then I 


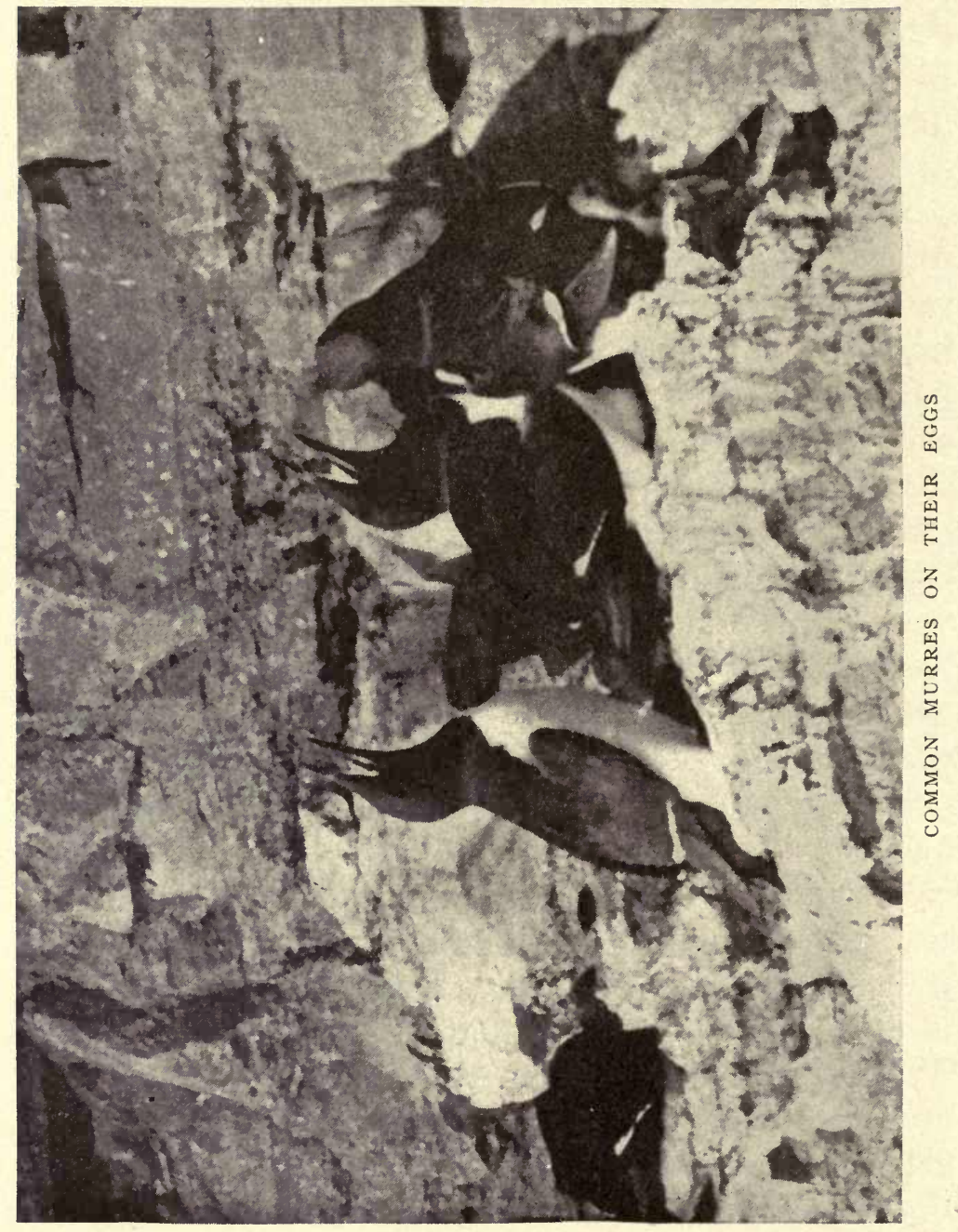


put in the plate and made ready, placing the camera in the same position on the railing, and making instantaneous exposures. The crate kept turning around, but so slowly that it made no difference, the view-finder of the camera giving the exact range. Thus I was lowered successively from ledge to ledge, swinging off in mid-air, till I had photographed everything within useful range, when I

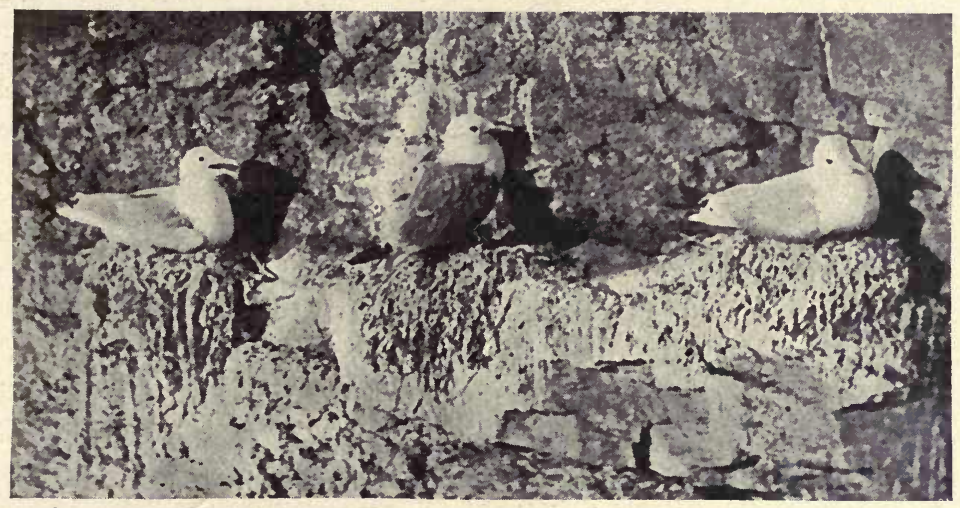

“JUST BELOW THEM [WERE] THREE KITTIWAKES ON THEIR NESTS"

signalled to be drawn up. There were no birds nesting close to the other hoisting-apparatus, or I should have made a descent there too.

Earlier in the afternoon we had seen a schooner anchor off North Bird Rock. A dory went ashore, and we could hear the gunshots as they were killing the birds. After a time the men rowed over to the main rock, landed, and two of them, and a boy, climbed up the ladder. The men went around shooting raking shots along the lines of birds upon their nests, mowing them down. Most of those killed simply lay dead upon the nesting-spot, where they 


\section{Among the Water-Fowl}

were inaccessible. A few fell to the water, and were picked up by the boat, where they had quite a pile of birds and a couple of pails of eggs. My indignation at this atrocity was tempered by the fact that the men were ignorant and probably hungry for fresh meat. Yet for all that they

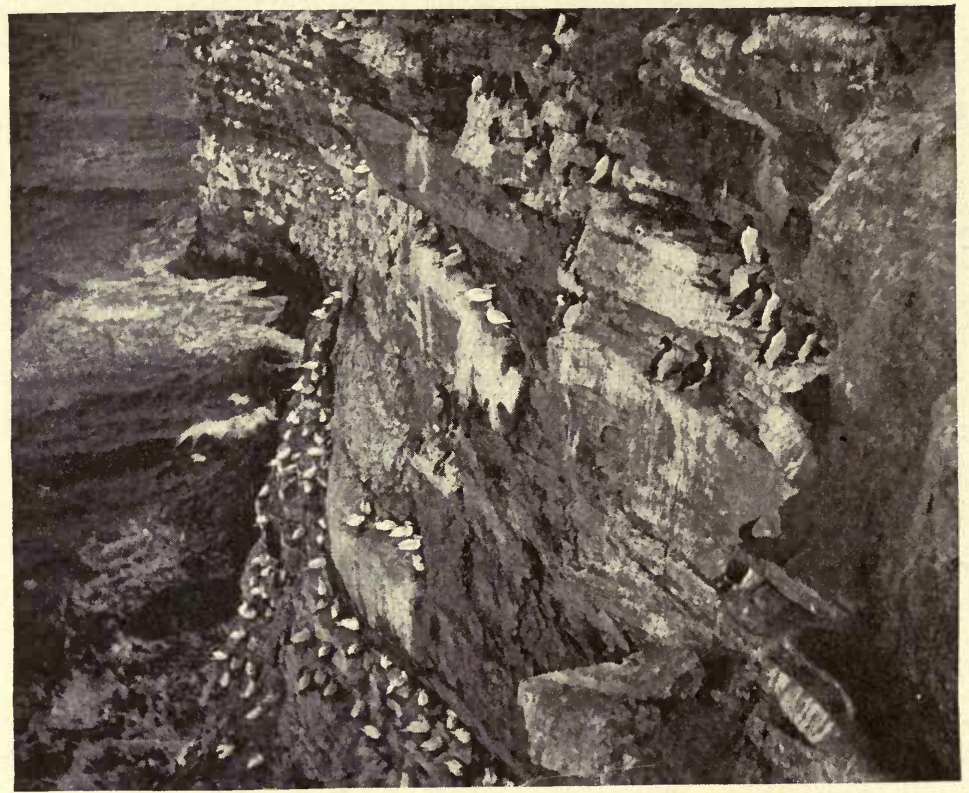

GANNETS, MURRES AND KITTIWAKES, FROM THE CRATE

ought not to be allowed to slaughter the breeding birds. Owing to this there are only a few thousands left here at present out of former innumerable multitudes, and all these interesting and beautiful sea-birds are becoming scarcer every year. Why cannot the Canadian Government protect them by law, and make these lighthouse keepers, or others, game-wardens, with full powers 
to protect the birds? This is something that bird-lovers may well strive to have accomplished.

Never can I forget the impressions of the Sunday that I spent on Bird Rock. The sky was overcast, with a very strong wind from the south-east, raw and chill, with occasional showers. The mercury did not rise above 50 degrees during the day, and the heaviest clothing was none too warm. Bundled up in overcoat and rubber-boots, I sat on the edge of the cliff among the rocks at the south end, and "beheld the fowls of the air." If possible, the spectacle was even more impressive than on the previous days of my stay, for it seemed as though every bird was in motion. This was in accord with the Keeper's observation that the birds fly most in windy weather. They were like the ships, that spread their sails to the favouring breezes. Each individual bird, seemingly, would sit upon its egg or eggs just enough to keep them warm, starting away for a few turns out over the water at frequent intervals. I could never tire of these sights.

On Monday morning the sky was again overcast, and, just as I had set out the camera to try a short "time exposure" on some Puffins, the rain began, and poured down furiously most of the day. Banks of fog lay off around the Rock, and the dynamite bomb exploded regularly every twenty minutes, the warning to vessels. The time was when these fog-signals frightened the birds, causing them to start so hurriedly from their nests as to cause many eggs to fall down the cliffs. But now I 
could not see that they were alarmed in the least by the explosions, and I did not see a single egg fall during my stay. This was the day when the schooner was to return for us, so, under the circumstances, we busied ourselves preparing a few specimens and getting ready for the possible departure, notwithstanding that it looked as though our visit might be prolonged.

Several land-birds had taken refuge on Bird Rock, one of which was a Long-eared Owl. Sunday night it flew out from under the lighthouse, and next morning the Keeper shot it as it flew out again. He thought it would kill his chickens, and, though such a practice is quite foreign to the species, I could not guarantee that it would not have done it under pressure of starvation. Indeed, who would not? As I entered the tool-house, a bird was fluttering against the window, a Black-billed Cuckoo, as I found by catching it, of which species I had seen several individuals on the main islands of the group. I let it go in the open, and off it went with the wind, northward, toward Newfoundland, where I trust it arrived safely in due time. I also observed a Bittern and a pair of White-winged Crossbills.

About the middle of the afternoon, with a change of wind to the west, the clouds broke and the sun shone out for awhile. I took a few more general views of the great bird-colony, and then set the camera on the rocks for shots at close range. But the birds were restless, flying almost constantly, and would not gather where I wanted them. Before I succeeded in getting a single group, we saw the schooner coming, several miles away. 
Soon the dory landed, and, bidding our friends good-bye, bag and baggage we were lowered down in the crate. I photographed the crate, and then the cliffs and the hoisting apparatus as seen from the dory. Soon we were on board the schooner and were scudding rapidly southward with free sheets, many of the birds following us in farewell salute, while other salutations came through bomb and flag, and we waved back expressions of our triendly feeling for the brave spirits imprisoned upon that grim, lonely rock.

To complete our study of the Cliff-Dwellers at the Magdalen Islands, several species that did not breed at Bird Rock had to be followed up. One was the Cormorant, that near relative of the Gannet, which differs from it, in colour, about as darkness from light. Evidently they were not plenty, for all we saw were an occasional one or two flying over the Bay inside Grand Entry, usually headed toward Shag Rock. Unlike the Gannets, too, they are exceedingly shy. All that I have ever met, here or elsewhere, that came near enough to be identified, were the Double-crested species. The so-called "Common" kind seems to be a very elusive bird, unless it be in the far north.

Evidently Shag Rock must be our destination, if we were to see much of the Cormorants. So one morning, with high hopes, we started out in the fisherman's boat for that grim little rock twenty miles to the westward. Unfortunately the wind soon hauled out ahead and died away completely. So, after get- 
ting half way there, we had to give it up, and going ashore on the sand-bar that formed the east side of the lagoon, solaced ourselves among the abounding Gulls, Terns and Plovers. Here, after all, we probably found more of interest than we should have done on the rock, for on our return we met a man who had been there a summer or two ago and had noticed nothing but Terns breeding. It is thus probable that the Cormorants use the rock merely as a roost. There were still the Black Guillemot and Raven to be investigated, and not far from our headquarters was a most picturesque place where both were found. This is a tremendous headland and cliff that fronts on the inside bay well up toward its head near East Point, known as "East Cape." One can walk up a steep grassy slope in the rear, and then look over a perpendicular cliff some two hundred feet high. The soft rock keeps crumbling away, and now and then a fragment falls, to add to the pile of debris that has gathered below, which in some places reaches half way up the cliff.

As we approached it the first time, in a boat, a flock of nearly twenty Ravens rose and hovered over the summit, startled from their nests or roost on the ledges, and flew away when they saw that we intended to land. The debris from the cliff came to the water's edge and made it a very rough spot for disembarking. But, having an off-shore wind, we luffed the boat up near enough to leap out. Black Guillemots, hearing our voices, began to fly out from holes high up above us, to settle well out in the water. By clapping our hands and shouting, we started a number more. Then, despite the 
frequently falling fragments, we climbed up the pile of loose rocks that sloped at a steep incline of more than forty-five degrees, and got about half way up the cliff. There we could see a number of the nests of the Raven, platforms of crooked sticks, placed on ledges of the rocks or at the entrance of small caves. One nest in particular was very large, almost like an Osprey's. None seemed to be lower down than somewhat above the top of the pile of debris, and the upper ones were not over fifteen feet or so below the summit of the cliff. Some of the young fishermen, I am told, think nothing of climbing down a rope to get Ravens' eggs. For my part I felt no inclination to try it, as, mid-way on the cliff, I gazed up and down the dizzy height, and finally picked my way down the rocks. Of course by this time the young were all awing, as the eggs are laid in the latter part of March or early in April.

There was no possibility here of reaching the nests of the Black Guillemot, but, fortunately, they were less inaccessible in certain other places. All over the Magdalen Islands scattered pairs nest in the caves that the sea washes out in the sandstone banks or cliffs. In one cave near our headquarters a pair had their two handsome spotted eggs on the bare rock of a little shelf, about as high as one could reach above the water. The only way to get at them was on a very calm day to row a boat right into the cave. As the inevitable swell rolled in after the boat, suggesting the effect that a larger wave might produce, the inclination was not unnatural to get out of the uncanny place as quickly as possible. 


\section{Among the Water-Fowl}

On the Fourth of July, the steamer arrived about the middle of the morning, and, bundled up in overcoats and winter clothing, we bade farewell to these wintry but interesting islands, in two days' travel reaching a temperature of one hundred in the shade in sweltering New England, when we wished we were back again among the Murres. Our experience tallied with that of the Gloucester fisherman who remarked that he had experienced three winters in one year-one at the Grand Banks, one in Gloucester, and a third with the summer mackerel fleet at the Magdalen Islands.

Better even than the Magdalens for the study of certain of these species that we are considering are some other places that I have visited. As for the Double-crested Cormorants, though I have not as yet been privileged to visit their breeding-grounds on the cliffs of Newfoundland and Labrador, I have become very familiar with a fine colony of them in the West, which I shall describe in another chapter. Regarding the Ravens and Black Guillemots, though they abound in the very far North, I do not know where they can be more easily and safely observed than on our own coast of Maine. Here their Mecca is the islands of Penobscot Bay, and they are accessible without risking one's life on the terrible cliffs of the northern seas. For want of such cliffs, where a nest is practically safe, the Raven considers a spruce tree amid the thick forests of the lonely islets as the likeliest shelter. Here 


\section{Modern Cliff-Dweilers}

many of them breed, and likewise on various spruc.grown islands of New Brunswick and Nova Scotia.

Though I have not visited their haunts at the nesting season, I nevertheless had the pleasure of a close inspection of a Raven's nest on an uninhabited island of Penobscot Bay. About the middle of May, when the Herring Gulls were laying their first eggs on this island, a party of boys discovered a Ravens' nest in a spruce tree, containing three wellgrown young. These they carried home with them, and were keeping them, when I arrived a month later, in a hen-house, as they had tried to escape to the woods. One day the boys took me to the nest. The spruces on the island are not large, and the nest, though two-thirds way up, was only about twenty feet from the ground. Climbing to it, I found it to resemble the Crows' nests seen on the island, only it was much larger. It was built of large crooked sticks, some of them as thick as one's thumb, hollowed deeply. The lining was of grass and sheep's wool, of which latter there was an ample supply from the flock that had been ferried over and left to run at large. The wellpicked carcasses that lay here and there suggested the well-known carnivorous habits of the Raven.

As for the Black Guillemots, on many a rocky islet there is a small colony of them, of from two or three pairs up to thirty or more. To one such, near Matinicus, I have often been. It is a lowlying strip, a couple of hundred yards long and rather narrow, composed almost wholly of round stones and boulders heaped together in wild confusion. Sometimes I have rowed there in a fog, by 
compass, again under clear skies, with calm summer sea. As we approach it is usual to see about thirty birds, some of them in the water just off the island, others sitting on the rocks, conspicuous with their deep green-black bodies and the large white patch on each wing. Watching a chance, we run the boat up on a flat ledge and haul it well out. The Guillemots fly, all that are in sight, but there are nearly as many more in under the rocks upon their nests, if our visit is within a month after the middle of June, at about which date the eggs are laid.

Now comes the awkward and possibly painful part of the procedure, if we would see their beautiful eggs-selecting a hole under some rock, particularly if there be droppings about the entrance, to get down flat on on one's face and try to look in. It may require many attempts of this kind before a discovery quickens the pulse. Knees are bruised, the back is tired and the neck is lamed. It seems as though there were a million stones to look under, and even thirty nests among them seem discouragingly few. But success is bound to follow. There is one flat rock where, every season that I have come, there has been a nest, so we will look there. Yes, there is the bird squatting far underneath. She sees us and scurries further back, leaving her two handsomely blotched eggs. The stone weighs more than a ton, so we cannot move it, nor are the eggs within arm's reach. But with a piece of driftwood, if we wish, we can pry them out over the pebbles, among which, without any soft lining, they are laid. There is little danger of breaking them, 
as the egg-shells produced by all these birds that lay on the bare rock are of flinty hardness-a wonderful provision of Nature.

There is a nice colony of some seventy-five pairs or more of these birds, along with many hundreds of the Arctic Tern, also on "Matinicus Rock," which locality I shall describe in another chapter. Here the Guillemots nest in great crevices or clefts of the main body of the rock and under separate boulders. Along with them are a few pairs of Puffins, this being their southernmost breeding-ground on the Atlantic coast. Strangely enough, when I was there last, no one in the two families on the little island had ever seen a Puffin's egg, though they had often tried to find one. There is no soil in which these "Sea Parrots" can burrow, so they crawl in under the largest rocks, and perhaps down under further layers, through winding passages. Try my best, I, too, had to own myself beaten in this search.

During one of my visits to this island I saw an albino "Black" Guillemot in the colony. At first it was out in the water with a flock of its darker brethren, acting and appearing just like the others, except for its colour. Later my companion surprised it sitting upon the rocks. It flew from a spot only a few feet from him, giving him a splendid view, particularly of its back. As far as he could see, it was of a creamy white all over, save for some gray markings on the back. Anxious to secure this remarkable specimen, I borrowed a gun from one of the Keepers, and went in search of it, without, however, being able to catch sight 


\section{Among the Water-Fowl}

of it again. No doubt it was taking its turn upon the nest. So anxious was I to learn of it further that, a few days later, I made a special trip again to this remote rock, only to be disappointed. I did not see anything of it, nor had any of the people noticed it. It was tantalizing probably to be walking a few feet over it, and yet, despite all my peering under the rocks, not to discover it.

However I was repaid for the effort by the privilege of examining a few more of the fine eggs of the "Sea Pigeons," each set different in markings and each nesting-spot chosen having some interesting feature. Even with all the din of the hovering Terns, we could often detect the location of the nest by a peculiar rustling sound, as the incubating bird scurried, at our approach, further under the sheltering rock. Then comes the pleasure and excitement of seeing if the eggs can be gotten at. And what a source of enjoyment it is to sit on the rocks, quite well out of sight, and see the pretty creatures pass and repass, often close to one's face, with that little murmuring sound, noting the green gloss of the black plumage, and the coral-red legs extended out behind, or dangling when their owner is about to alight. Now and then a Puffin whirrs by, giving variety with its grotesque, painted bill and its paler orange legs. After many circlings back and to, out to sea and in again, at length a Guillemot alights quite near. Then another comes, and presently there is quite a little group, perhaps eight or ten, waddling about, or sitting in a slanting attitude, not as erect as the Murres, it seemed to 


\section{Modern Cliff-Dwellers}

me, nor as horizontal as the Puffins. How these scenes impress themselves on the memory of a bird-lover!

After the breeding-season the various CliffDwellers leave their summer haunts and scatter over the ocean, yet keeping mostly "on soundings." By the latter part of September, or early October, lines of Cormorants, with slow, measured flight begin to wing their way along the southern New England coast, even flying over the land. Many people mistake this for an early flight of Geese, and wonder why they fly at this time in silence, without "honking." Quite often flocks alight in the larger ponds to rest and quench their thirst. I recall how, one beautiful October day, about thirty of them settled down in Lake Nippenickett, and remained out in the centre for over half an hour, resting and drinking the fresh water. Then they rose, to continue their southward flight. Unfortunately for them they passed over a gunning-stand on a point of land, where a hunter lay in wait for ducks. Though they were quite high up, one shot took effect, and a great black creature came tumbling down. When I reached the spot I found that it was a Double-crested Cormorant. At any time during the autumn they may be seen resorting to certain low, rocky islands and ledges off the coast, and to some extent during the winter. Returning northward in the spring, they gather in flocks in certain bays, and fly out, often over projections of land. A fisherman, some years ago, told me that 
they did thus from the bay at Plymouth, Mass., crossing Gurnet Beach, at which times they were easily shot. During late fall and winter the socalled "Common" Cormorant is also found sparingly along the coast.

It is late in the fall, about the first of November, before the Murres and their allies stray as far from their northern haunts as the Massachusetts coast, beyond which not very many of them ordinarily are supposed to go, except as they are driven by severe northerly gales. They are hardy creatures, little inclined to migrate from the latitude of their breeding-grounds, save as the closing in of the ice makes it expedient. Most of them keep well out to sea, especially frequenting the shoals and banks where fish are abundant. If the season is mild and devoid of severe gales, they keep well to the north. In very wintry weather they come in around the mouths of harbours. One bitter December morning, with the mercury at zero, I watched a group of Murres in Lynn harbour, off Nahant. There was a channel-post that sloped considerably with the tide, and these Murres would waddle up the incline, sit awhile, then dive headlong, and climb up again, seeming to greatly enjoy this sport. They do not ordinarily come in large numbers into Cape Cod bay, though off Manomet I occasionally see in the winter a line of Murres skim by. One calm, misty day in December, as I lay at anchor there in a dory off on the fishing-ground, watching the Gulls and Gannets, a solitary Razor-billed Auk suddenly emerged from the swell only a few feet away, and for some minutes bobbed around in the 


\section{Modern Cliff-Dwellers}

usual comical manner, with "stern" high out of water, its tail erected, squinting at me with its sharp little eyes. Suddenly it sank, as mysteriously as it had appeared, and that was all I saw of this waif of the ocean.

While it is not surprising that birds like the Puffin and Razor-bill, that breed quite far to the north, prefer to winter north of Massachusetts, we certainly might expect to see more of the Black Guillemot, since it breeds so abundantly no further away than the coast of Maine. Now and then I have seen a small party of them in mid-winter off the rocks of Manomet, and similar places, yet rather infrequently. But around Matinicus at that season they are more abundant than ever. How different our familiar "Sea Pigeon" looks in its winter dress, the biack of summer changed to gray and white. The only thing about it that looks natural is the white patch on the wing.

I know of no better place to observe the seabirds off the Massachusetts coast in winter than on the fishing-grounds off Chatham. One favourable day in my experience will illustrate what may be seen. I was spending Christmas week with a fisherman for the purpose of studying the various marine birds, and had arranged with him to sail me out over the bars upon the first possible occasion. For nearly the whole week the bars were too rough to cross. But on the last day of the old year, dark and threatening though it was, we made the attempt, and succeeded in getting "outside." Just off the entrance we began to meet Brunnich's Murres bobbing about on the water. By the time we got 
three or four miles off the land, the sea was fairly alive with them, while Kittiwakes, were flitting about in all directions, plunging Tern-like into the water after small fish.

I shall never forget the scene that ensued when a school of these small fry rose to the surface, probably chased by the Haddock or Dog-fish below. The birds instantly discovered the school, and made for it. The air was full of excited Kittiwakes, hovering, plunging and fluttering up with their prey. Line after line of Murres likewise came flying up, and, pitching down into the water, dove and fed. In a few moments the water for about an acre was a mass of struggling birds. At length they so alarmed the fish that these preferred facing their finny enemies to this feathered onslaught, and, with a simultaneous leap, they were gone. It was surprising how quickly the birds scattered again.

We beat some eight or ten miles off-shore against the moderate easterly wind to the fishingground, noticing that the line of the greatest abundance of birds was about half way out. Yet there were quite a few birds on the fishing-ground. As we hauled up the slimy Cod, Hake and Haddock, the beautiful Kittiwakes hovered close around usso unlike the wary large Gulls - as though begging for the titbits of liver that we now and then threw them. They seemed to have absolutely no fear of man, flying back and forth so near us as barely to avoid our sail and rigging. It almost seemed that they could be taught to feed out of one's hand. The Murres, or " Noddies," as the Chatham fishermen call them, came also for their share. As they 
paddled around close to the stern of the sloop in the characteristic attitude of this class of birds, breast well down in the water and rump considerably elevated, I thought of them as miniatures of the ancient ships that Virgil wrote about, with their "lofty sterns." I used this opportunity to try to discover some of the "Common" Murres among this horde of Brunnich's, but did not see a single specimen that I could recognize as such. This seems to be the universal experience of observers, and now, despite the older accounts, it is questioned whether the "Common" Murre is ever found as far south as Massachusetts.

One special treat was in store for me. While I was fishing, happening to glance " to the nor'ard," I saw a very small bird skimming like a bullet low over the sea, making directly for the boat. It passed close by on tiny, quick-beating wings, and, giving me only this brief, precious glimpse, speedily disappeared to the southward. It was no less distinguished a personage than the Dovekie, or Little Auk, the only one that in all my winter ocean wanderings I have ever seen alive.

Next day, celebrating the New Year, I was wandering along the grim, icy beach along the "back side of the Cape," watching the birds and the breakers. The bedraggled carcass of a Razorbill brought to mind the thought of the terrible winter storms that destroy these poor creatures by the thousands. It is well known that they are sometimes blown inland, to perish in the snowdrifts. One of my early recollections is of a Puffin being found in Jamaica Pond, Boston, after such a storm. 
Only a tew days before this writing, in December, a man showed me the remains of a Brunnich's Murre which had been captured forty miles from Long Island Sound, in western Connecticut, the day following an easterly gale and snowstorm. The poor thing was standing on the ice over a small river. Though too much exhausted to fly, it made quite a spirited resistance before it allowed itself to be taken by hand. The captor was actually cooking the emaciated body for supper when I arrived upon the scene, which repast I felt no desire to share.

From the standpoint of many, January is an uncomfortable time for wandering on sea and shore in search of the birds. On the contrary, the ocean is at its best and grandest in winter. Would one see waves? Take the train for the coast when the wildest gale of the winter is raging, and there will be sights to stir the most siuggish blood. And as for sea-birds, there are few indeed in summer, as compared with the ever-changing panorama of fowl that wing their way over the unutterable wildness of ice-bound bay and restless wintry sea. Can one be a thorough ornithologist and not know the seafowl? Most of us must begin with the door-yard birds. But as the desire grows for more of this interesting bird-lore, we may expect that it will lead us to visit mountain and forest and shore, even the wintry ocean itself, whenever and wherever the wildest of the feathered tribes are to be found. 


\section{PART III. \\ OCEAN WANDERERS}

(Shearwaters, Skuas, Petreis, Phalaropes)

I SHALL never forget the day on which began my intimacy with a class of birds of whose existence I had been hardly more than aware-birds that

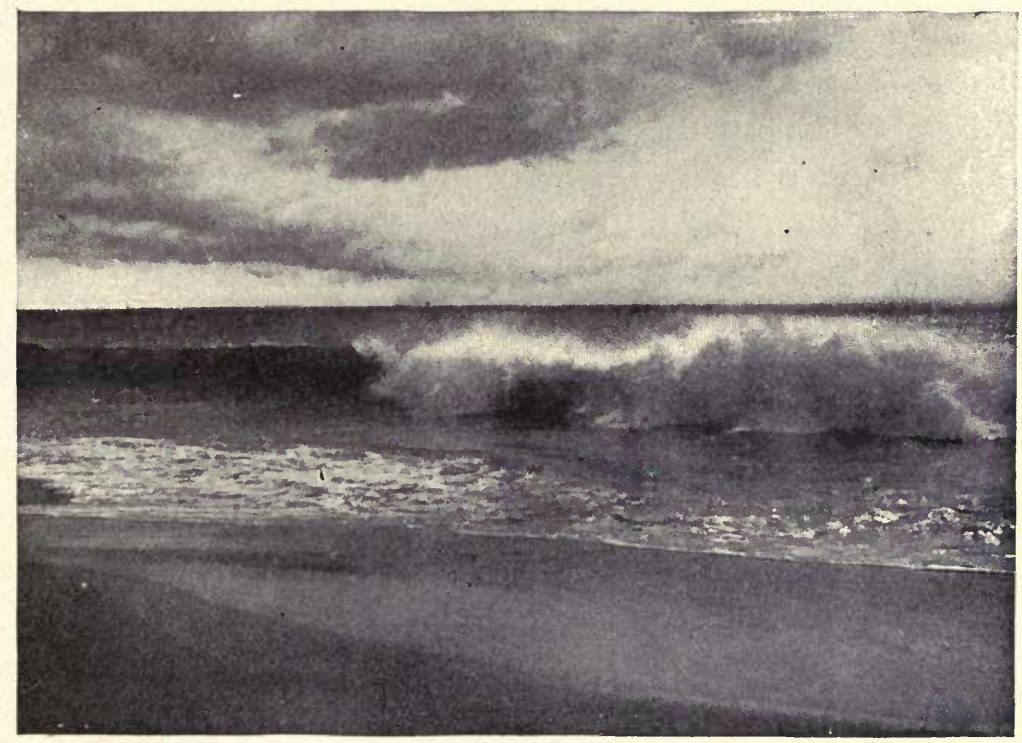

THE REALM OF THE OCEAN WANDERERS

OFF EAST POINT, MAGDALEN ISLANDS, FAR FROM HUMAN HABITATION

make the billows of ocean their home. It was the twelfth of July. The first gray of the morning found me, with a party of friends, scudding down the bay of Chatham, Mass., in a fishing sloop. A light south-west breeze and a racing tide swept us 
out over the agitated waters of the harbour-bar, than which there is none more dangerous on our coast. Then the fiery ball of the sun rose from the ocean, dispelling the morning mist, and drying the cold, wet decks of the fishing-fleet. Off to the south-east we sped, crossing the track of various coastingvessels four or five miles off shore, losing sight of land a dozen miles out, and yet pressing on, till, after about four hours' sail, we were some twentyfive miles off the Cape. Here dwelt the denizens of the deep. Majestic among them all were the Finback Whales, a band of which were playing about, as though for our special amusement. Several times a great fellow emerged so close to us as to alarm even the fisherman. It was a most impressive sight, as the water rushed with thundering roar from the great back, and the spout of white spray accompanied the mighty outbreathing - "the blast of the terrible ones . . . as a storm against the wall." Great swells lifted and tossed the sloop, so prostrating one of our number with the sickness of the sea, that he could hardly be induced, as he lay torpid and miserable on deck, to even raise his head and see a Whale that rose within fifty yards of us.

We all set to work with the lines, and soon great flopping Cod, Hake and Haddock were rapidly filling the "kids," or lockers. And around us gathered the feathered wanderers of the ocean floor. About six miles out the first one had appeared, a rather large bird with dark back and white breast, that, with a peculiar gliding flight, on long, narrow wings which it held slightly decurved at the 
intervals of sailing, skimmed low over the surface of the water in an irregular course, till lost to sight. The name "Shearwater" had been to me a mere book-term; henceforth it was a reality.

A few miles further out we noticed a flock of about twenty birds resting on the water. As we approached, we saw that they were of the same sort, except that one was of a dark sooty colour. The skipper, who knew their ways, mischievously steered the boat just to windward of them. The wind was then very light, and the sail shut off, for the time, what little there was, so that the birds, as they were quite tame and did not rise soon enough, found themselves unable to leave the water. One of them, by frantic flapping and paddling, just managed to clear the bow of the craft and avoid being run over. The others turned, and fluttered off to leeward, squawking and wailing in their terror. The dark one was of the species called the "Sooty Shearwater;" the other kind bears the specific name of "Greater."

Before this I had only one or two distant glimpses from steamers at Petrels, or "Mother Carey's Chickens." Out here the curious little swallow-like creatures-sooty in colour, except for a white band on the rump-were everywhere flitting and pattering about. They fly in the most irregular manner, as though they had no special destination in view, as indeed they have not, careless where chance may lead, if only it is to food; and it is surprising how quickly these ocean wanderers can discover the presence of a supply. After we had fished awhile, the skipper suggested that we 
throw out some cod-livers, and see the birds. Just then, as it happened, there was but one bird, a Shearwater, in sight. It was but a moment or two before it spied the mass floating on the water, surrounded by a greasy "slick," and, alighting beside it, proceeded, with satisfied grunts, to gorge itself in the most eager and gluttonous manner, as though afraid that another might come to share the feast. This evident anticipation was certainly well founded, for in a moment, as though out of space, a Petrel appeared, then another Shearwater, and soon there were over fifty birds around us. Perfectly fearless, they would swim or fly up, and almost take the liver from our hands. It was a most animated and interesting scene.

This first day gave me yet another acquaintance. As we were nearing the fishing grounds, I spied a large dark bird approaching, higher up than is usual with the Shearwaters, flying more like a Gull. "A Jiddy-hawk," exclaimed the fisherman, and, seizing a clam from the "washer," he tossed it over the side. The bird would have passed us at some distance, but no sooner did it see the fisherman's movement than it turned, and swooped down to the water, quite close alongside. Then I knew that the mysterious "Jiddy" was the Pomarine Skua, or Jaeger-of a tribe that are a sort of predatory adjunct to the Gull fraternity. We saw but two more that day; a little later in the season they were abundant.

Since that interesting day of initiation, a number of years ago, I have made many more trips thither, and to other parts of our coast, to study 
these ocean wanderers, and have come to know them quite intimately, as they are seen in this part of the world. Yet a most interesting part of their career is still buried in obscurity. The Shearwaters are now believed to breed in the Antarctic regions during the southern summer, about January or February. Like their allies the Petrels, they nest in burrows in the ground or holes in cliffs. After this they start wandering, and where do they not go over earth's oceans? They wander up the southern seas, cross the equator, and, according to the fishermen, appear off Nova Scotia and on the "Banks" about the first of May, following the migration of various fish. They are found all over the northern ocean until autumn, when they gradually withdraw, as cold weather comes on. The fishermen rarely or never see them in winter, and I myself have seen but one, a Greater Shearwater, I took it to be, the last day of one December, about eight miles off Chatham.

The Jaegers, on the contrary, are raised in northern latitudes, in the short summer of the barren arctic solitudes. Thence they begin to wander down to the New England coast in July. By August they become common, and in September and October they are abundant in suitable localities on the ocean. With the advent of winter most of them proceed further south.

Our Petrels are both northerners and southerners. There are two kinds common on our coastLeach's and Wilson's Petrels. The only perceptible difference between them is that the former has a forked tail and black webs between its toes, the latter 
a "square" tail and yellow webs. They are hard to distinguish at any distance, and thus one might overlook the rarer, though very similar, Stormy or Least Petrel, which I have never certainly identified. Leach's Petrel breeds from the coast of Maine northward, while the other goes with the Shearwaters to the mysterious far south. During summer, when our northern Petrel is breeding, it is usually the southerner that we meet off our coasts. All that I have identified off Cape Cod at that season were of the latter kind. In the autumn we find both kinds intermingled. As for winter, it has never been my fortune to meet any Petrel at that season, though they may occur further off shore.

Out of the very many trips that I have made into the haunts of the ocean wanderers, mostly off Chatham, I will cull out some of the more noteworthy incidents that will illustrate the habits of these unique and interesting birds. One that stands out in my memory was the second of August, away back in I883, when I met for my first and only time a certain rare bird. As usual, I was with a fisherman off Chatham, well out to sea. Among the many Shearwaters- "Hags" or "Haglets," as the fishermen call them-I noticed an individual resembling the Greater Shearwater, but lighter in colour in the back, and with a large, conspicuous yellow bill. I had not the least idea what it was, and my naturalistic ardour rose to white heat. Fortunately there was a gun in the cabin. I made ready, and when, at length, the strange bird again flew past, I tumbled it into the water. Luffing the boat up to it, I laid down the gun, and was about to 
seize my prize, when there came a sudden reviving. Wings were spread, and away it went, right from under my very nose. I felt the keenest disappointment until, on the return trip, another of the unknown birds came in sight. With palpitating heart I threw out livers, and as eagerly did it accept the invitation. This time the bird was mine, and subsequent research identified it as Corey's Shearwater, which had been newly discovered to science only a couple of years previously, in the very same locality. As far as I know, I was thus the second naturalist to secure a specimen. This is the nearest I ever came to being the discoverer of a new species of bird. I saw that day one other specimen, and thought that all of them acted precisely like their more familiar relatives.

When I compare the two common Shearwaters, I recall little that is distinctive, other than their colour. 'The Sooty fellow seems a little the heavier built, but this does not appear to affect its flight. I love to watch either of them fly. On a windy day when, away out there on the boundless deep, the swells are assuming almost alarming proportions, and the advancing wall of water menaces the little white-winged sailing-craft that lies deep down in the hollow, the Shearwaters are in their element. With quick beatings of wing they dash past in the teeth of the breeze, dirigible flying-machines that they are. Now they set their wings, fully extended and slightly depressed, and scale along the trough of the sea, the tips of the wings almost touching the water. Then they turn, and shoot up over the breaking crest of the wave, the blast turning them 
to one side, and away they go across the whitecapped ranges of ocean mountains. Wild things they are, living that roving life on the unquiet ocean, knowing for months no real resting place. How can they rest amid the breaking seas? Who knows, when the gales blow for days at a time, whether they remain all that time, day and night, upon wing, or settle momentarily on the agitated water, till a breaking surge soon forces them awing? And how fare the seemingly puny little Petrels, so slight of form that they appear like little dark butterflies or tufts of down, driven by every blast?

At times the storms are indeed more than they can bear. I have seen dead bodies of Shearwaters on the ocean beach, and once I was witness to the close of the wandering career of a Leach's Petrel. It was during the raging of an October hurricane from the northeast, when, impressed by the sublimity of the forces that were uprooting trees and multiplying destruction upon the land, I took the train to Sandwich, on Cape Cod, that I might witness the effect of the storm upon the ocean. Those who have been by the sea at such a time can realize much that I witnessed. It was well worth braving the beating rain and the furious wind to see the surges thunder in upon the sand, the white, seething cauldron of the ocean, and the hordes of water-fowl, mostly sea-ducks of various sorts, thousands upon thousands of them, that were passing, some skimming low over the waves, others blown in over the beach. Strong of wing, the gale but helped them on their southward course,- - yet not all. As I stood on the sand, I noticed a flutter of wings amid an 
advancing wave. Something was cast struggling ashore, helpless before each succeeding wave that worried it as a wild beast its prey. When I reached the spot, I picked up a Leach's Petrel. Poor thing, it was bedraggled with water and with its own oil, and evidently near the bourne of life. The kindest thing I could do was to put my heel on it and end its sufferings. I wondered if this were not one of innumerable like cases, where the bird tires of being kept awing by the raging of the elements, and falls, at length, exhausted, into the vortex of destruction.

The movements of these birds depend largely upon the supply of food, which consists of small fish and all sorts of minute marine creatures. They love to congregate where whales are found, to pick up any leavings and secure their share of the small bait-fish that the monsters pursue. Shearwaters and Petrels are redolent with oil. When handled they squirt out a yellowish oil from the nostrils. When the whales are about, the water has sometimes, in calm weather, seemed to me noticeably greasy, and I was tempted to imagine that the Petrels, that were everywhere pattering about, were engaged in skimming from the water choice and nutritious whale-oil! The birds are scavengers in part, but one wonders what they find to eat, as there is so little on the ocean surface visible to the human eye. The fact is, however, that the upper stratum of the ocean teems with life.

One is never sure of finding them abundant in any one locality, even on successive days. Now and then I have seen numbers of them just off Chatham Bars, but usually they are not common 
much in-shore from " the Crab Ledge," a fishing ground about eight miles from land. And then, again, they are away off on "Rocky Ground," twenty miles or more off shore. Still, it is wonderful, when vision and other resources fail to place them, to try the judicious use of cod-liver. Again and again, when not a bird was in sight, and I was satisfied that they had gone off shore, as the boat sailed along I have tossed out now and then a piece of liver, squeezed into fragments. In the course of some ten minutes, a Petrel would be seen, hovering far astern, feasting greedily. Soon the supply was garnered, and the "Mother Carey's" followed up the wake of the boat. No matter how fast we sailed, the ever hungry bird soon caught up and flitted close about, as though begging for more. Not only one, but another and another, a Haglet, a Skua, and before long we had the usual company. I would not assert that by the chemical union of cod-liver and oxygen Shearwaters are produced, and from liver and hydrogen Petrels, though at times it almost seems so. Try it and see! Yet I should advise one not to expect too much, unless there is a likelihood that there is at least one Petrel within a few miles. The solution is, I take it, the acuteness of their vision that enables them to see others hovering and feeding at a far greater distance than we could descry them.

These ocean birds seem to have some power of observation as to the weather. Fishermen had told me that Petrels flock before a storm, but it was long before I observed it for myself. At length, one afternoon in August, we were sailing in from the I06 
"Rocky Grounds," when a thunder squall began to roll up from the westward. The clouds grew very dark, the air was quite still, and lightning-flashes appeared shoreward. Just then we sailed by a flock of Petrels, closely grouped upon the water. There must have been over a hundred of them, and others kept arriving, alighting in their midst. Though at rest on the water, they kept up a constant fluttering or trembling of the wings, and emitted low, twittering notes. They certainly seemed ill at ease, and I do not doubt that the approach of the storm had this effect upon them, as the skipper said it was a common habit at such times. Poor little things, this was all the refuge they knew how to take, the solace of companionship at a time of possible danger.

Petrels are thus named from their seeming ability, like Peter of old, to walk on the water. In reality this is only done in appearance, for, though they patter over the surface with their long, slender, black legs and little webbed feet, the wings are kept constantly in motion, and it is these that really support them.

The time came when photography was made an adjunct to bird-study, and one August day the camera and I made our first joint trip out over Chatham Bars. This summer the fish were schooling well in-shore on the "Crab Ledge," so we did not have to start till half-past five. In a couple of hours we were on the fishing-grounds, the day partly cloudy, and the wind light from the southeast. Birds seemed unusually scarce. Except for 


\section{Among the WATER-Fowl}

some Terns near land, I did not see a single one till we had been fishing half an hour. Then one Greater Shearwater came flying around after something to eat, and presently a Wilson's Petrel. This made me realize that we might yet have company, so I cut out some livers and threw them, piece-meal,

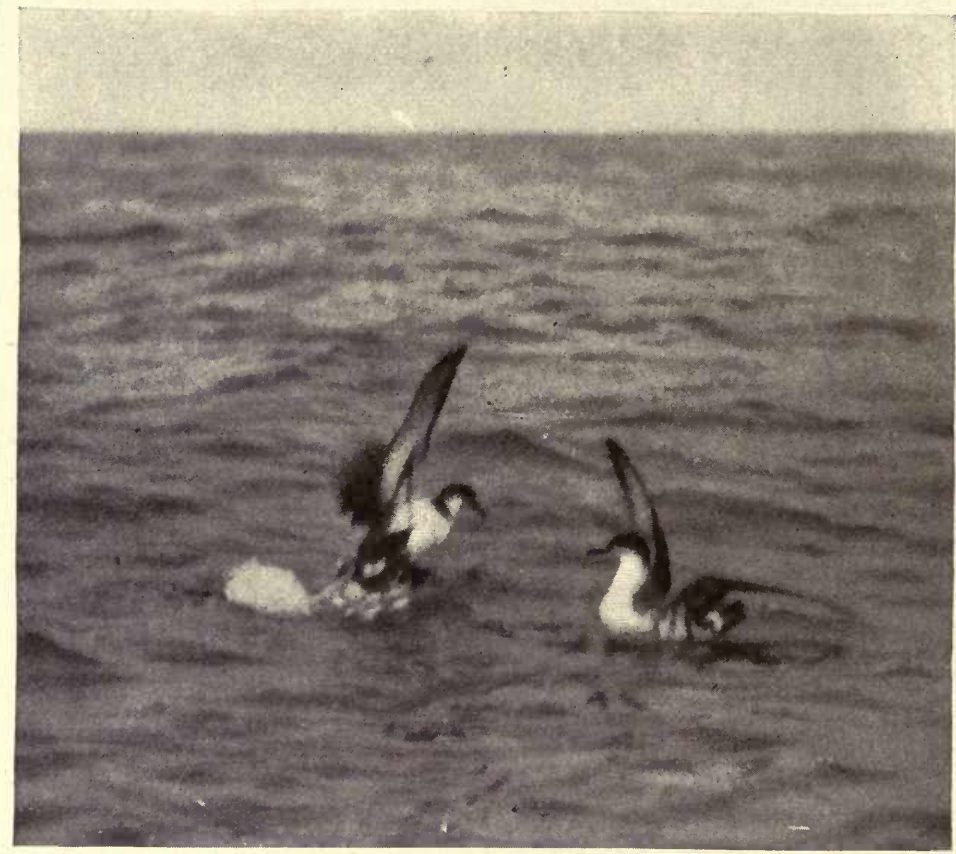

“ PRESENTLY I HAD A PAIR OF GREATER SHEARWATERS BOBBING AROUND THE BOAT, GULPING DOWN LIVER GREEDILY."

astern, the strong tide carrying them swiftly to leeward. The old method worked like a charm. Presently I had a pair of Greater Shearwaters bobbing around the boat, gulping down liver greedily, and quite a number of Petrels pattering and fluttering about. Still they came, more Petrels and Shearwaters, then several Sooty Shearwaters and a 


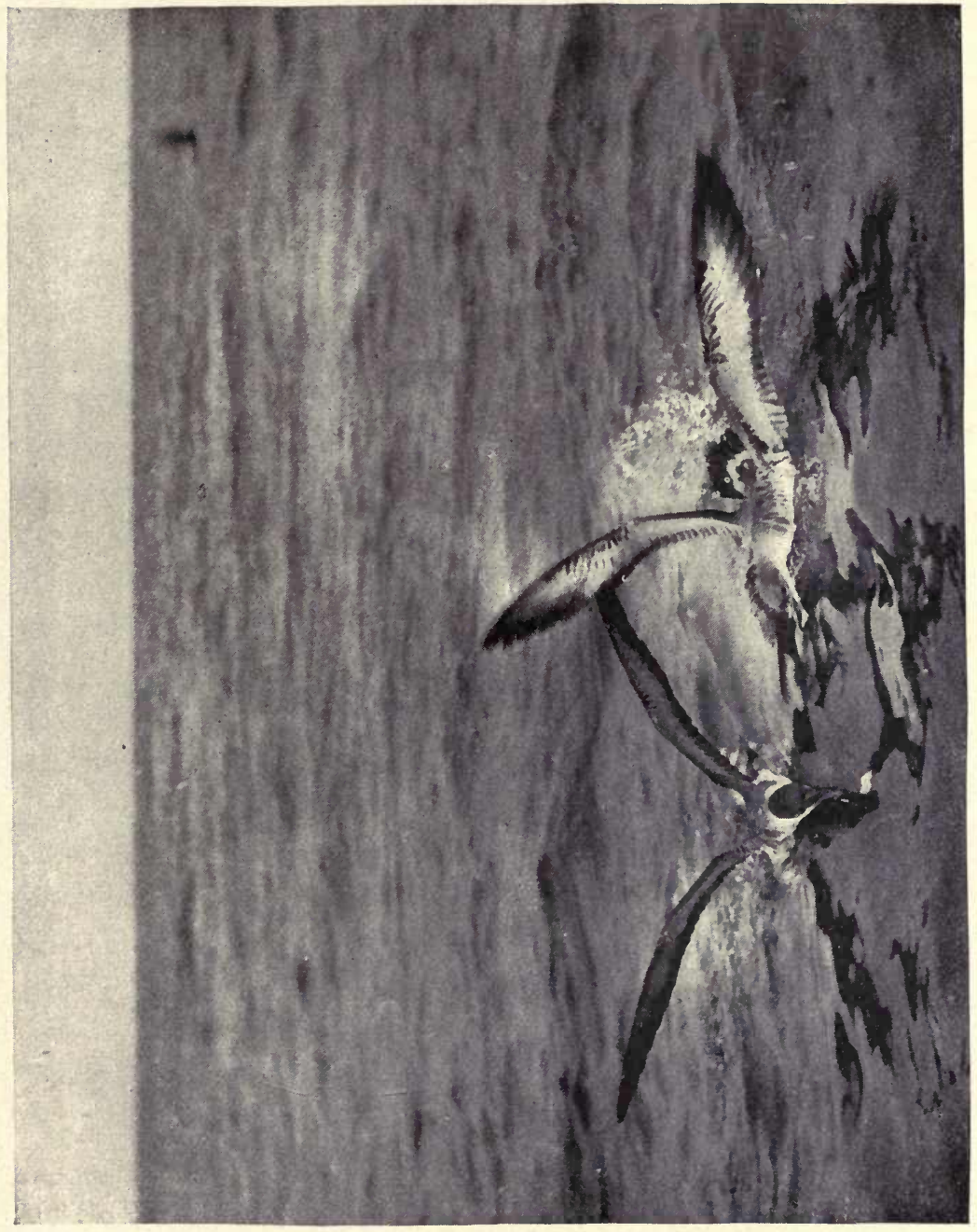

$\dot{x} 0$ i

$\approx \leftarrow 0$

四告

$<\propto$

F

द $\geqslant$

利卷焉

क 空

学

밥

4

这 
few Pomarine Jaegers. The latter were shyer than the others, remaining, for the most part, on the outskirts of the group, though now and then venturing nearer for some specially tempting morsel. In half an hour we had a hundred birds close around us. The "Haglets" and "Mother Carey's" were exceedingly tame. They would come right up to the side of the boat to secure a piece of liver, and once I actually caught a Petrel alive by giving it a little poke with a gaff, seizing it before it could again get awing. I nearly induced a pair of Shearwaters to eat out of my hands. They would swim up, extend their bills within a foot of the liver, and gaze at it as wistfully as a dog does at a bone. As soon as I dropped it, they would pounce upon it, extending their wings and uttering peculiar grunts and wailing sounds.

And here is how I got my photographs. I made ready the camera for an instantaneous exposure, and, by the focusing-scale, set the lens for what I guessed would be the proper distance. Then I enticed the birds as near the boat as possible by throwing out liver close alongside. With greasy hands I caught up the camera, made a final guess at the focus, and snapped at the birds before they were off. A Reflex camera would have been far better for this work, but I had to make the best of the apparatus at hand.

Sometimes I threw out a whole handful of liver a little farther from the boat, and instantly there would be a frantic scramble for it of all the birds nearest. The Shearwaters seemed particularly quarrelsome, and how they would fight for that liver, 


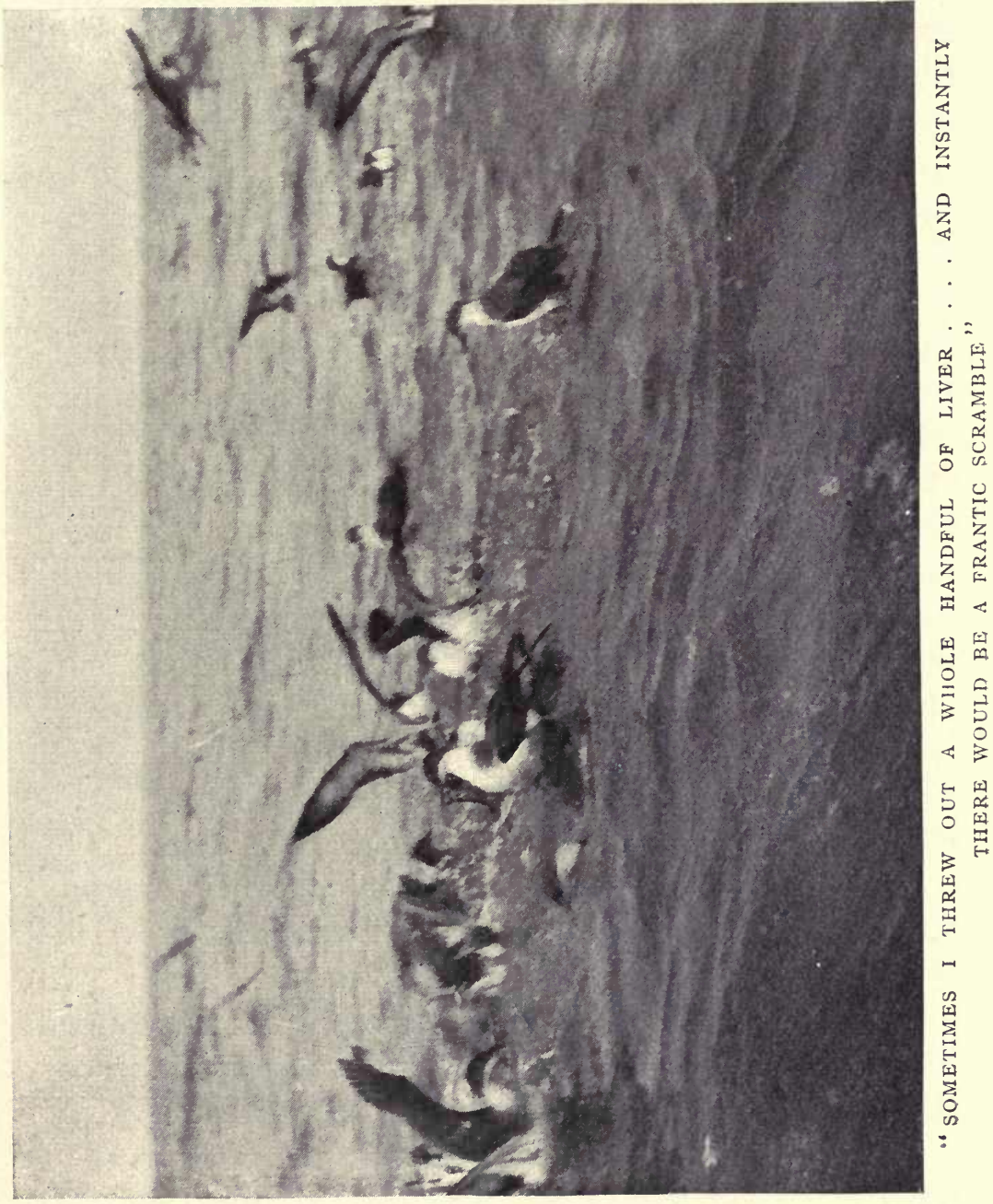




\section{Among The Water-Fowl}

squealing and biting at one another with every possible exhibition of passion. If the liver is car-ried under by the tide, several birds at once dive after it, and, emerging amid the excited crowd, will bear up on their backs others that happen to be over them,-as is shown in the illustration. While resting on the water, they often extend their wings, perhaps in readiness to flutter and paddle after the food they are expecting to be thrown out. It is rather hard work for them to start in flight, unless there is a good breeze, and they have to run pattering with their feet over the water for some distance before they are fully awing.

The fishermen had told me that the Haglets are readily caught with hook and line, and I now tried the experiment. Baiting a small hook on a light line, I tossed it over. A Shearwater immediately pounced down, dove after the sinking hook, and cleverly bit off the bait. I tried again with a larger piece, but jerked it out of the bird's mouth. Next time I waited until the thing was half swallowed, and then slowly drew the line taut. The hook caught in the bill, and, despite frantic flapping and bracing the feet against the water, I drew the victim, a Greater Shearwater, into the boat. No sooner was the line slacked than the hook dropped out, having held only slightly in the horny part of the mouth, not injuring the bird in the least.

Finding that the bird could not rise from a hard surface, I gave it the freedom of the deck. It ran into a corner, and squealed and bit when I attempted to handle it. It was awkward in gait, and now and then would fall down, evidently being 
rather out of practice in pedestrianism. In the same way several more were captured. When released, at length, by being thrown into the air, they went scaling off over the ocean. I could not tell whether or not the same individuals returned to the feast, as they were soon lost among the many that were flying about.

The skipper said that out on the Banks the fishermen catch the Haglets and put several of them together in a barrel to get them fighting. Each seems to consider the others its enemies, and they will all set to screaming and tearing at one another in the most desperate fashion. From the accounts of this Hag-baiting I should judge that Game-cocks and Kilkenny Cats had at least their equals in these marine fighters. I could not quite bring myself to experiment with this cruelty, contenting myself with the description, that the traits of these birds here observed made entirely credible.

It was much more difficult to photograph the Petrels than the Shearwaters. They moved so quickly that it was hard to get the camera focused and aimed at short range before they were off, and, even when I did, the motion of their wings was so rapid that it required more speed than that of an ordinary shutter. To-day, however, with the new Reflex camera or the focusing finder, these difficulties have been greatly lessened.

Once out on the fishing-grounds, aside from the vicissitudes of the elements, there is always the delightful uncertainty as to what a day may bring 


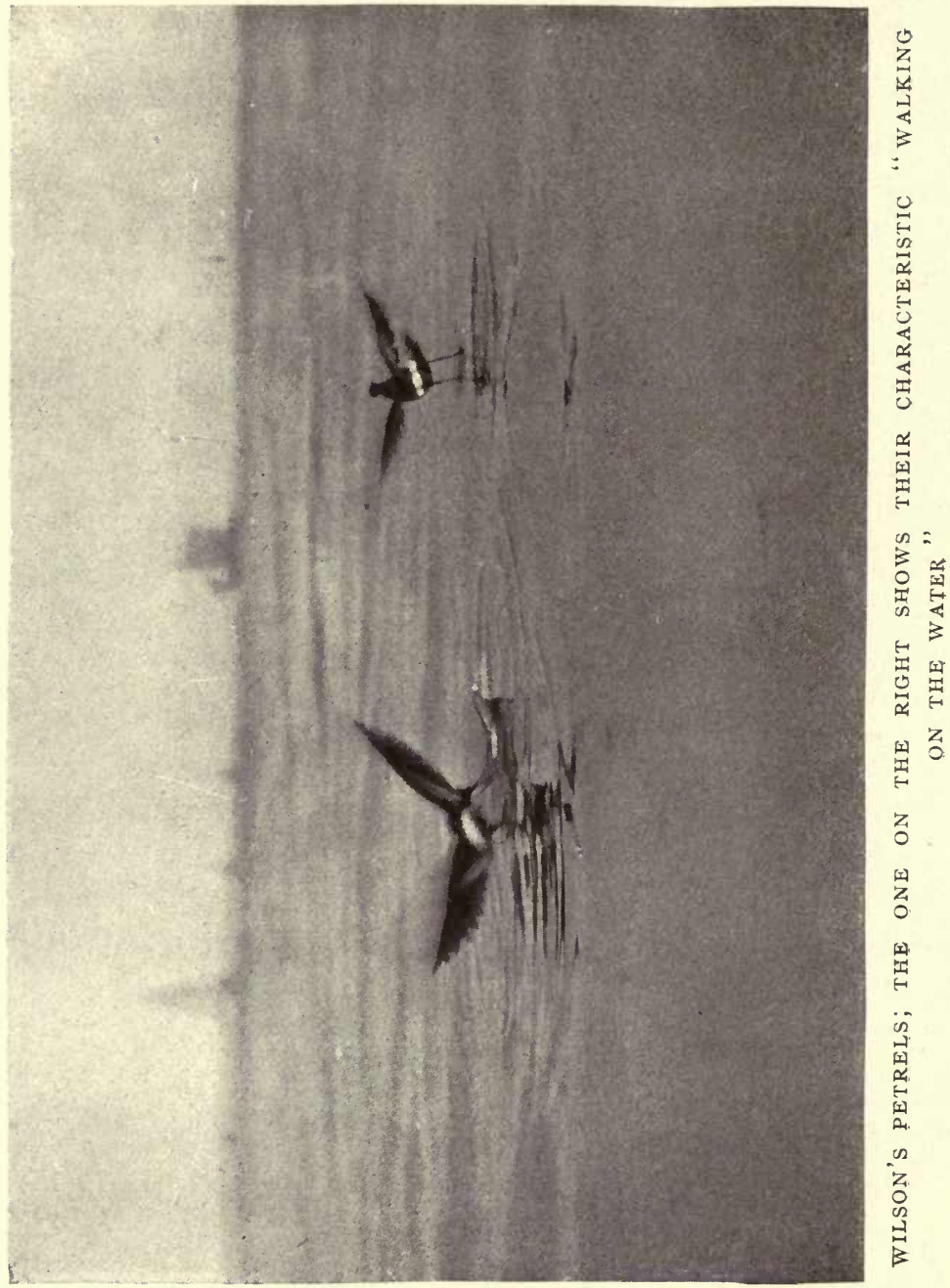


forth. As at our "Expositions," different classes or nationalities have their "day," so off on the sea, perhaps for purposes of exposition to the ornithologist kindly furnished by Providence, different kinds of birds have theirs. Usually the Greater Shearwater is the abundant "Haglet," outnumbering their dark-hued relative twenty to one. But now and then comes a "Sooty day," when the order is almost reversed, though the disproportion is seldom as great. Perhaps there is a "colour-line" among the Shearwaters, so that when the "coloured" Hags in large numbers invade the "Crab Ledge," most of the lighter-coloured aristocrats manage to find more congenial marine pastures elsewhere. At times in August we are treated to a "Phalarope day," when rafts of these dainty little creatures dot the water far off shore.

But, of all these special occasions, I know none more entertaining than "Jaeger day" at this great marine exposition of Nature. One such that I shall ever remember was the 26th of August, four years ago. Long before we reached "Crab Ledge" I knew it was " Jaeger day," for the great dark fellows were everywhere about, chasing the Terns and Bonaparte's Gulls in their savage fashion. And what a strange fashion it is! If a Tern or small Gull happens near a Jaeger, there is almost certainly trouble in store. The latter gives chase. The pursued makes every effort to escape. But the Jaeger,-well named he is, " hunter,"-is the better flier. With savage swoops, he strikes his little white cousin from this direction and from that. Mounting in the air is of no avail. So at last, in 


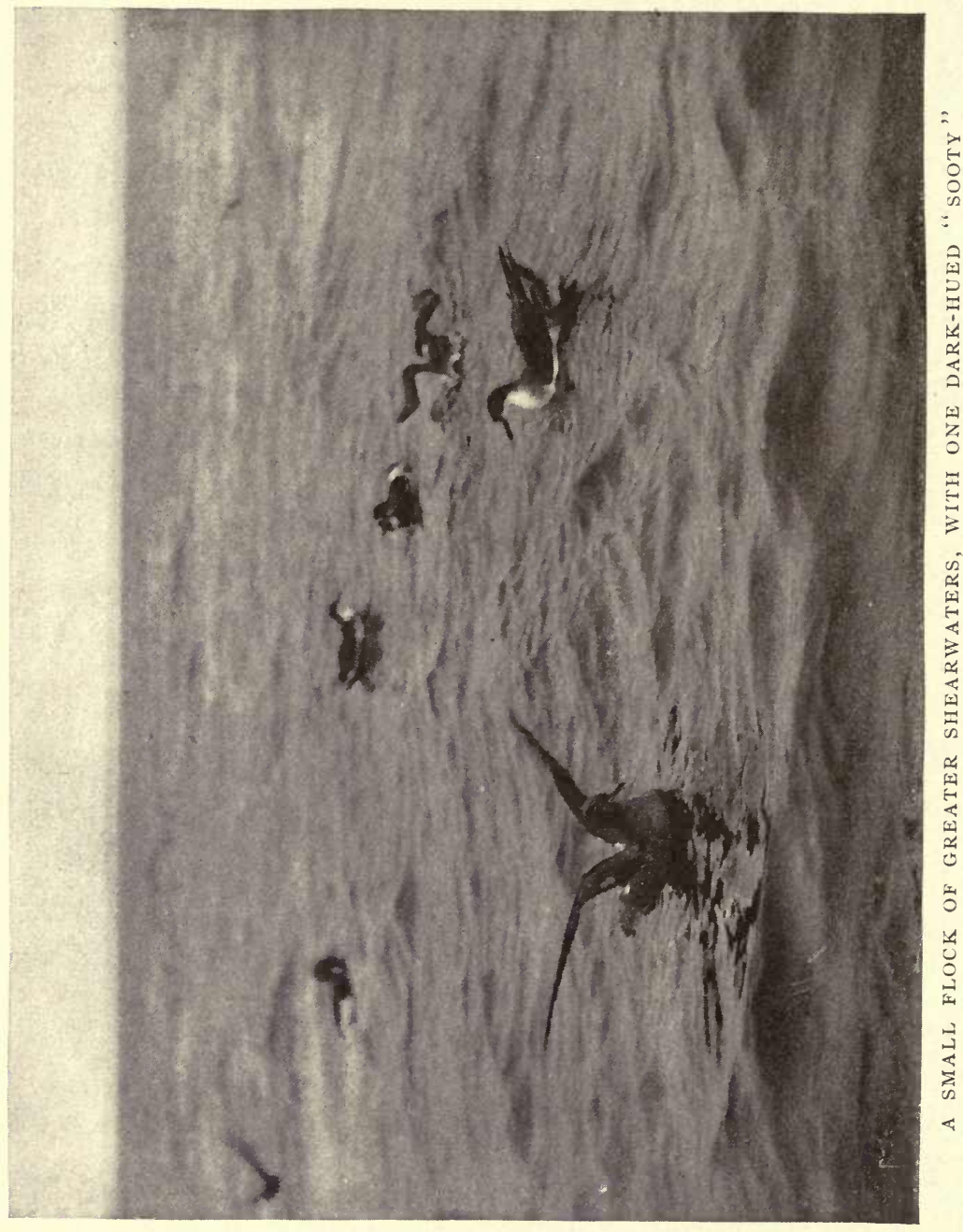


fear and despair, the Gull or Tern does what it knows the robber wants, disgorges the hard-earned contents of its crop, - a choice fish, or a mass of half-digested matter. No further use, at present, has the pirate now for his victim. Poising for an instant, he swoops down after the meteoric shower of food, usually catching it before it reaches the water. If not, he alights, gathers it in, and then kites away in search of another swallow of the sea, on which to pour the vials of his wrath. There are so many more of the hunted than of the hunting, that the former might easily combine and mob the marauder, did they but know their real power.

We saw this process repeated until we were too far off shore for Terns to be often found. But the Jaegers do not depend upon Terns; they can forage for themselves, and, in fact, they do it for the most part. On the fishing-grounds I was delighted to find them as abundant as Shearwaters, or even more so. They hung about us all day in large numbers, and partook of the liver that I threw out to them. Despite all my efforts, I could not get one near enough for a satisfactory picture. Perhaps I might have done so, but for the tamer Shearwaters, that were always the first to gobble up any bait near the boat, before the Jaeger, hovering off in distrust, could make up his mind to venture. This time we had towed out a little skiff, and, as it was quite calm, I rowed off in it from the vessel, hoping that in this way I might approach them. The Petrels came up very close, but the Jaegers, though they flew rather low over my head, would not come down near, where I wanted them. 
The specially interesting feature of this influx of Jaegers was the variety of their plumages. It seemed as though there were no two individuals alike. This was not altogether a surprise to me, as the fishermen the day before had told me that there was an unusual flight of " Jiddies." The Pomarine Jaeger, the largest species, is here usually the commonest, and was certainly so on the present occasion. A smaller species, the Parasitic Jaeger, was about half as numerous. I did not see any of the LongTailed Jaeger, which, according to my experience, is far scarcer than these two, only scattering ones appearing now and then.

Each of these species is found to assume a number of types of plumage, and even experts are considerably at sea regarding their sequence. As the birds now flew about the boat, some had long tails, some short ones; some had white breasts, others dark; some were in light plumage, some in a phase of a sooty color; some were marked, others plain; some were barred, others speckled, and so on, this being true of both kinds. There is a great deal here to learn. I would suggest that some competent naturalist go out there with the fishermen, catch a number of Jaegers, and watch their feather-changes in captivity. Such an experiment would furnish a very instructive chapter in ornithology, could it be carried out.

Better in some respects than the waters of Cape Cod for observing the habits of the Ocean Wanderers and other water-birds are those off Cape 
Sable, Nova Scotia. Though more difficult of access, there is no harbour-bar to cross. Perhaps the Shearwaters keep off-shore, for I have not found as many of them there as at Chatham; but it is a fine place for the Jaegers. The fishing-boats there are mostly poor, frail craft, such as no Chatham fisherman would tolerate, yet their owners venture in them well off the land. During September and October the Jaegers become specially abundant, congregating in localities on the ocean where the bait-fish are plenty. Late one September I made a vigorous effort to see these birds at their best, and sailed out early one morning, with two fishermen, to the cod-grounds. Pomarine and Parasitic Jaegers were fairly common, but the wind soon breezed up so that, in the crank little boat, the fishermen were afraid for their lives, and put back to land. It was a fine sight to see the powerful birds, exulting in their strength, patrol the tossing ocean and exact from it tribute.

The next day was cloudy, with a good breeze, the last of my stay. I hired a larger and better boat, and put to sea after the Jaegers. We saw a few flying to the southward, but, though we sailed well out to sea, and up and down the coast, we failed to. reach their real haunts. When farthest to the southward, we noticed the masts of a fishing-fleet in the distance. And when at night this fleet made port for shelter from the approaching storm, and one of the men told me what he had seen that day, I felt angry with myself for my obtuseness. The fleet of schooners were bunched together on a shoal twelve miles southeast of Cape Sable, catching and 
dressing fish. Around them, feasting on the refuse, were literally thousands of Jaegers, or "Sea-Hens," as he called them. They kept coming from all directions throughout the day, - of all sorts and sizes. What a sight it must have been! The few birds flying towards the fleet would be suggestion enough now as to where to go. But it was too late for after-thoughts. Next day, with the first snow in the air, and a furious, biting north wind, I said farewell to the haunts of the Jaegers.

There is another class of birds that, during their stay with us, at any rate, deserve to be included among the Ocean Wanderers,- - the little Phalaropes. They are classed among the wading-birds, and resemble closely small Sandpipers; but in their habits they are quite unique. In their marital ways they are said to reverse the ordinary course of Nature, the females doing the courting, and the males attending to the household duties, such as incubation. One species, the Wilson's, of which I shall tell in another chapter, breeds on the western prairies. Two others, the Northern and the Red Phalaropes, breed in the far north, and occur along the Atlantic coast in spring and fall as migrants. Away out at sea, often far out of sight of land, we find them at these seasons in flocks flying about with twittering notes, just like flocks of Sandpipers, but alighting on the water like genuine water-fowl. They show better their "wadership" when they meet with areas of drift-weed, and, settling down upon it in large numbers, run nimbly about, seeking their food, of small marine creatures.

Off Cape Cod I have been accustomed to see 
occasional flocks of Phalaropes, or "Whale-birds," as the fishermen there call them, during August. Once, in the middle of June, I met a flock of twenty No:thern Phalaropes just off Matinicus Rock. But I never had any conception of the abundance of these pretty birds in their migrations until one August, off Cape Sable. The fishermen told me that Hags, Sea-Hens and Mother Carey's Chickens were less plentiful than usual that season, having followed the fish elsewhere, but there were " millions of "Sea-Geese." " From their description I knew that these latter were Phalaropes, and I took an early opportunity to pay them a visit.

I was fortunate in securing passage on a substantial little eleven-ton schooner, manned by a father and two or three stout sons. It was a nice day with a light breeze, most favourable for the work in hand. We glided from the sandy cove with its wharf and fish-houses, and by the time that the white beaches and green spruce-tracts were becoming dim in the distance, seeming to slide away from us, rather than we from them, we were in the haunts of the Phalaropes. Flocks of them began to fly by, and then we passed flocks in the water, sometimes quietly dressing their beautifully smooth plumage, or splashing and frolicking on the smooth ocean surface. Every bunch or patch of drift-weed supported all the Phalaropes it would hold.

We began our fishing when the land was but dimly in sight. All around us the Phalaropes were flying and sporting, always in flocks of half a dozen or more. Each tiny bird, when at rest, rode lightly and gracefully upon the water, and I was reminded 
of squadrons of miniature ships riding at anchor in some harbour. At length I gave up fishing, and rowed off from the vessel in the heavy keel tender, right among the birds that would hardly get out of my way, so tame were they. I think I had not realized how many there were till I came to an almost solid mass of them that covered acres of water. It seemed that such a flock would certainly be shy. Not so; as I rowed toward them they hardly deigned to notice me, and when I was very close, instead of flying, they merely swam to one side, opening up a sort of lane through their ranks, through which I rowed, after which they simply closed up again.

Being so near them, I was able to learn accurately what species were represented in this host. Nearly all proved to be the Northern Phalarope, the smallest kind, but there were a few of the Red Phalarope, - a slightly larger and plumper bird,scattered through their ranks. Some of these had still a few ruddy feathers in the breast, the last remnants of the summer plumage; but most of them were now white-breasted, and bluish gray on the back. At a distance it was not easy to distinguish the two kinds apart by colour alone. The fishermen had told me that for the last two weeks they had not seen any more of the red-breasted ones. They did not know that this was simply due to the moult, and that the birds were really there all the time.

So much interested was $I$ in the Phalaropes that I failed to observe the approach of a Nova Scotia fog. The first thing I knew I had lost the vessel. 
At length I saw through the haze what I took to be the right one. After a short row against the tide and an increasing wind, just as I was almost within hail it squared away and left me. Then I took another course, and, after nearly an hour's futile effort, had begun to wonder what my chances were of being able to row that heavy craft against the wind to the distant invisible shore, without food or water, when the familiar schooner loomed up not far away, and I was far from sorry to set foot again upon her ancient and slimy deck. Though I had a camera with me on this trip, it was before the days when I realized its value as an adjunct to bird-study. I would give a good deal now to be off there again among that assemblage of birds, properly equipped.

Early the next morning the fog was very dense on shore, and I found quite a few of the Phalaropes, in small groups, on the marshes, feeding like the other numerous waders, at the edges of the pools. They were gone, though, as soon as the fog lifted. The fishermen say that this is about the only occasion when they ordinarily come to land. One morning, early in this same August, before I had arrived, the fog was especially dense, and at daybreak they encountered very large numbers of the little things on the flats, as they were starting for the day's fishing. The birds departed as soon as it was fairly light. Occasionally great numbers of Phalaropes are reported on the New England coast, but I have been off there hundreds of times, in various years, only to see comparatively small, scattering flocks. Hence I incline to the opinion that, in the 
fall flight, like the Golden Plover, most of the Phalaropes, after leaving Nova Scotia, pass so far off the coast that we seldom encounter the main body of the migration.

The only species described in this chapter with whose breeding habits I am, or am likely to be, familiar, is Leach's Petrel. The nesting of most Shearwaters is practically unknown to science, and upon that of the Jaegers, except in northern Europe, only arctic explorers can enlighten us. But many of the islands off Maine and Nova Scotia have been adopted by multitudes of Leach's Petrel as their summer home. At different times, from Matinicus to the Magdalen Islands, I have examined their rat-like burrows. Seal Island, off southern Nova Scotia, is a wonderful Petrel-resort. There I have noticed a variation on their usual habit, in that they enter the spruce woods, and dig their burrows under the roots of the trees. It is about the last place in the world that one would naturally search for a bird that loves a free, wandering life over the billows, - a damp, dark hole underground, and in the midst of a forest. But these extremes in habits make bird-study all the more fascinating.

A more typical breeding-place is some such spot as another Seal Island,-this one off the coast of Maine. I was, with a friend, at Matinicus Island. Learning of this remarkable resort of the Petrels, only seven miles away, we engaged a schooner to carry us there, leave us for the day, and take us off 


\section{Ocean Wanderers}

at night. It was Bunker Hill Day, splendid weather, and a fine, fair breeze. We got an early start, and in three-quarters of an hour, sailing "wing-a-wing," we were off the island, a grimlooking rock, covered with green-sward on top, a good half-mile long, and rather narrow. One of the crew rowed us ashore on the less precipitous western side. Even there it was not much sheltered, as the mainland was twenty miles away, and even in calm weather the sea broke not a little on the rocks. However, watching our chance, we managed to scramble out on a shelving ledge, immediately after which the retreating wave carried back the boat. The schooner departed for the fishing ground, while we scrambled up the rocks and bank to the summit of the island.

No sooner had we reached the turf than I noticed a little burrow, and my friend at the same moment another, and there they were all around us. Selecting one, I pulled up the sod with my hands. The hole did not go straight down, but ran along just below the roots of the grass, for about a couple of feet. Then it broadened out into a sort of pocket, in which, on a slight lining of grass and feathers, sat a Leach's Petrel on a single white egg. The bird seemed dazed by the sudden glare of day, and did not make any effort to escape. When I took hold of it, it made just the least bit of a struggle, and squirted out from its nostrils on my hands a few drops of yellowish oil that gave forth a peculiar, disagreeable odor. When I opened my hand, it did not make any attempt to fly off. When placed on the ground, it merely squatted, but 
presently arose to a crouching attitude, and ran back into what was left of the hole. Then I gave it a toss into the air, and, after a little zigzag meandering over the grass and rocks, it seemed to get its bearings, flew down in its usual irregular manner to the water, and disappeared off to sea, without showing any inclination to return to the nest, nor did it, that we could see, during the day.

We dug out a number of other burrows till we had seen enough to generalize the observations a little. We did not find more than one egg in any nest, and I do not know that any such instance has ever been recorded. Sometimes there were two birds in a burrow, but in these cases the egg had not been laid. 'Two birds that I took in the act of incubation from different nests and kept as specimens proved to be males. Some observers have thought that the male usually incubates, but others are said to have found birds of either sex indifferently thus engaged.

The puzzle is what becomes of the other partner. Practically never is a Petrel to be seen by day about the breeding-grounds. At night, however, the Petrels become active and noisy, twittering constantly, and flying to and fro from the sea. We cannot assume that the other is in some hole near by, for all the birds found are incubating. The fact also that the males incubate precludes the possibility of their deserting their mates, as is the case with the Ducks. Until something to the contrary is shown, we evidently must be content with the old theory that one bird of each pair flies out to sea during the night, leaving the other on 
duty till its return after the shadows have again fallen, either to bring food and again depart, or else to take its turn on the nest and let its mate go foraging.

At the further end of the island we had noticed a shanty, and after awhile we went to it. A lone and bold fisherman had ensconced himself with his family on lonely. Seal Island for the season, where he was practically monarch of all he surveyed. He told us that he remained there lobstering and fishing until about December. As he told of all the wild fowl he saw and shot during the fall, I almost envied him, except for his inability to view his advantages save from the culinary standpoint. Every bird was of interest only as it was good to eat. In this connection he "drew the line" on the Petrels. But he had a big Newfoundland dog that thought otherwise. The owner told us that the animal got his own living unaided, Petrels forming his chief provision. Practically the whole island was burrowed full of them, and, even while we were conversing, the dog would now and then paw out a burrow and eat a poor Petrel, feathers and all, with the egg for an appetizer! The whole island smelt of Petrels, - that peculiar, unmistakable odour. One would think that any vessel, passing anywhere to leeward of Seal Island, would get a whiff from that great hatching-coop of Mother Carey's Chickens.

We passed the day very pleasantly, exploring caverns, hunting the cliffs on the seaward side for the nests of the Black Guillemot, inspecting also nests of Savanna Sparrows, Spotted Sandpipers, and also one of a pair of Barn Swallows, the latter built 
on to the rock in a sort of open cave part way down the side of a deep rift, - a case of reversion to the original habit of the species. At sunset we mounted up on the highest part of the island, and strained our eyes to catch sight of the schooner. It began to get chilly, and our prospects seemed excellent for an involuntary night-study of the Petrels. But at last, sail ho! In half an hour the vessel anchored off the island, and we were presently sailing back to Matinicus under the silver rays of the moon.

At this visit the Petrels had just laid their eggs. Most of my other trips to their breeding-grounds have been also at the laying-time, and I should never have known the quaintness of the young Petrels, except for one delightful morning on Seal Island, Nova Scotia. This was in early September. From nearly every burrow into which I inserted my arm,whether in pasture, woods or gravel-bank,-I drew out a young Petrel. Some were completely feathered, and, but for the down that still clung to the ends of the feathers, they might have been taken for adults. Others could not boast a single real feather, yet were warmly clad in a dense gray down, a little lighter in colour than the regular plumage. Between these extremes there were all stages. But every youngster that I examined was fatter and heavier than an adult. There was not a parent with the young in any of the nests that we examined. The keeper of the light said that the old birds flew in at night and fed the young. That they performed this duty well was evident enough. I could not but wonder, though, how late it would be in the 


\section{OCEAN WANDERERS}

season before the young were all able to leave the nests. Probably it is this tardiness that makes some of the fishermen believe that the Petrels hibernate in these burrows, and come forth in the spring sound and strong.

But the Ocean Wanderers need not our theorizing or assistance; they are a law unto themselves. We cannot hope to follow them in all their devious and trackless wanderings. Storms that destroy us are to them of little moment. For decades yet they will seek out their arctic and antarctic solitudes beyond our reach and ken. Yet though they regard us not, we shall know more of these wild, free roving creatures the more that we, like them, love to be

"Rocked in the cradle of the deep." 


\section{PART IV}

\section{THE WHITE-WINGED FLEET \\ (Gulls and Terns)}

ONE beautiful summer morning, awaking to view again the splendid panorama of land and sea that is spread out before the bluffs of Manomet, we saw that during the night the mackerel-fleet had arrived. The sea for miles around was dotted with the white sails of the schooners, about forty being in sight. With the gentle breeze they were tacking back and forth, each with its group of keen-eyed fishermen on deck. Now and then an agitated appearance at some spot on the ocean surface betokened the rising of a school of mackerel. At once we would see seine-boats hurriedly launched, and rowed out by their crews to surround the wary fish. For two days the fleet remained, making a scene of beauty and activity long to be remembered. Then we awoke to find that they had departed as suddenly as they had come, taking with them the charm that their presence had added to the surroundings.

But there remained another white-winged fleet. Beautiful Terns were flitting over the sparkling water, and plunging headlong into it after an humbler finny prey. Before long the large white Gulls would come from the north, and patrol these shores in winter, when the Terns had sought a warmer clime. There is no class of birds more beautiful, 


\section{The White - Winged Fleet}

more interesting, more picturesque than these exquisite snowy-plumaged creatures, most of them pearly-mantled, that grace our lake and ocean

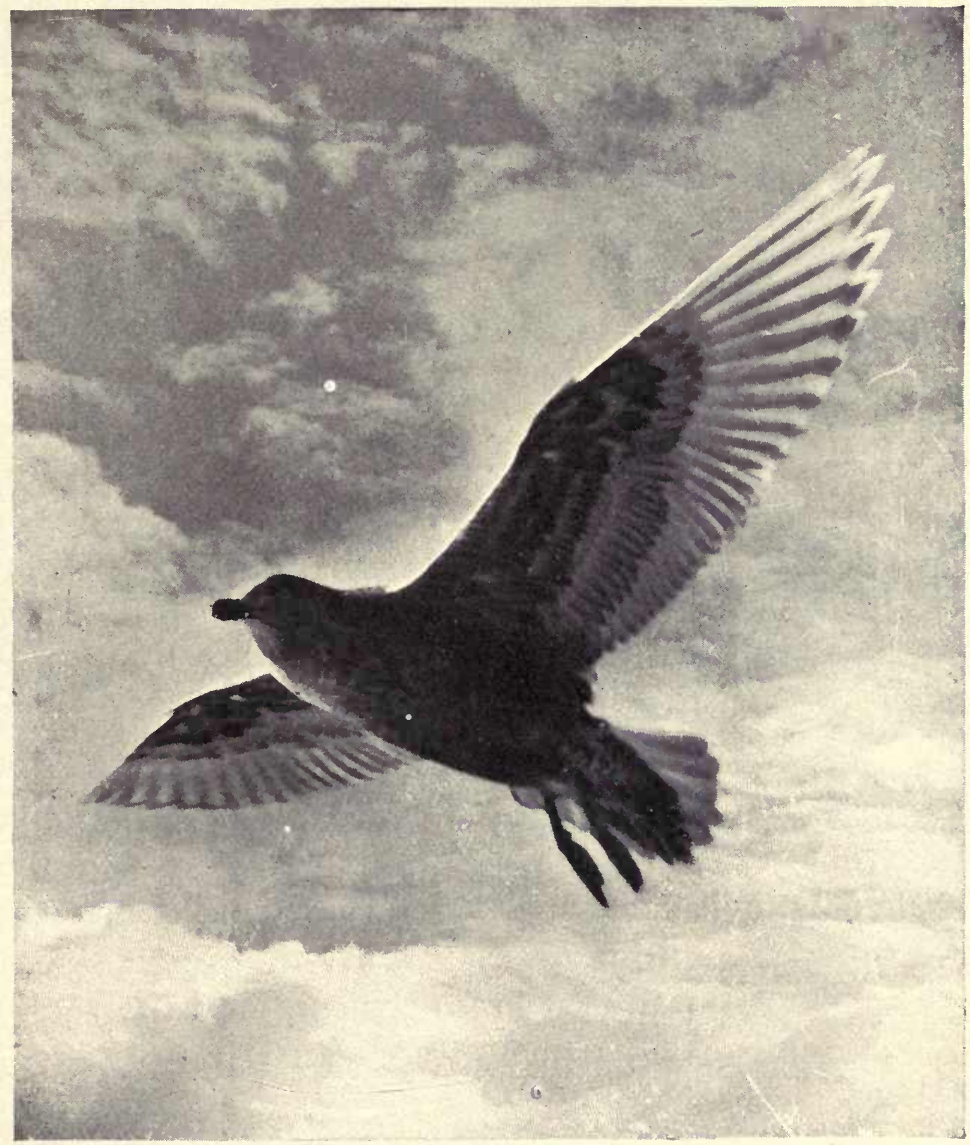

GULL IN FLIGHT - PROBABLY THE WESTERN GULL. A WING STUDY BY OTTO VON BARGEN

shores. With easy flight they winnow the air, wheeling and circling even to the clouds. Some dart headlong to surprise the wary fish; others float down like snow-flakes to take what the sea has 
cast up for them. Again, they gather together, either in buoyant flocks upon the water, or to dress their spotless plumage upon the strand. The loss would be unutterable were this fleet to be lost in the gale of fashion upon the cruel rocks of a selfish and senseless millinery decree.

Social in disposition, it is the universal habit of these dainty creatures to resort together in large colonies at the nesting-season for the rearing of their young; and of all the picturesque spots on earth, I place in very high rank certain of these breeding-colonies. One there is in Nova Scotia, which seems to me to be particularly beautiful. With two companions, I stood one clear, calm morning of early September, upon a wharf at Clarke's Harbor, Cape Sable Island, listening to the tale of woe of our would-be fisherman-skipper, as he portrayed the impossibility of reaching Seal Island, twenty miles out to sea, against strong head tides, and with what little wind there was also contrary. This was our last chance to make the trip, and I could not bear to abandon it. So, after the prophet of evil had departed, I proposed that we start off without him in the twenty-three-foot sloop. It was slow work, but at length we sighted the rocky shores and spruce-grown area; and by sundown the sloop was anchored off a cove, and we were receiving the royal hospitality of kind-hearted John Crowell, the light-house keeper.

Before sunrise next morning we were in the light-house tower. The cold, dark sea, foam-flecked, spread out beyond, the shores of Nova Scotia dimly visible to the northeast. Before us stretched the 


\section{The White - Winged Fleet}

dark, spruce-covered island, spectacle-shaped, the two lobes connected by a narrow bar. Dotted all over the spruces were snowy Herring Gulls perched upon their tops; many others were already a-wing, flying out to sea to feed, squealing and cackling incessantly. The sky was clear, and the east already rosy red, changing its hues moment by moment, as the sun approached the horizon. All at once the glowing orb seemed to fairly bound from the deep, and instantly the whole scene was wonderously transformed. The ocean, recently so dark, now glittered and sparkled as with myriad diamonds; the spruces reddened under their baptism of fire; the Gulls were gleams of living radiance. From the spruces extended a long line of them in flight, going a mile or more out to some shoal water, where a large flock were riding at anchor, and others were

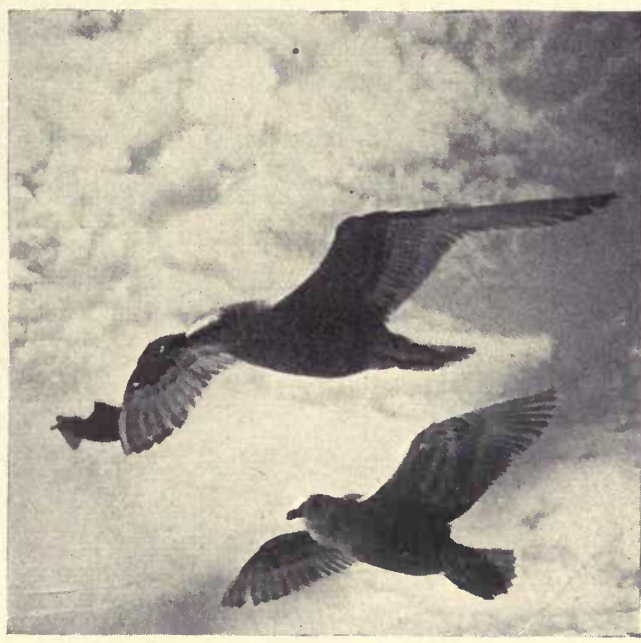

WESTERN GULLS. BY OTTO VON BARGEN hovering over schools of fish. "Devil's Limb," the grim rock of Cormorant-resort to the westward, looked less forbidding in the glad sunshine that warmed up its wet, ragged sides into the semblance of a smile. 


\section{Among the Water Fowl}

We lingered awhile, spell-bound at the vision, then we started out with the keeper to see the bird-wonders at closer range. Black Guillemots bred abundantly in the crevices under the loose rocks that were piled up on the shores by the fury of the gales. The breeding-season was over, but some still sunned themselves on the rocks, or were swimming or diving off-shore. Crossing the sandbar, where Yellowlegs, Turnstones, and Sandpipers fed, we inspected some of the abounding Petrels' burrows, and then turned our attention to the great colony of the island, that of the Herring Gulls. The usual custom of this species is to select or make a hollow in the ground, and build around it a nest of grass, feathers, and seaweed; but sometimes - on account of persecution, it is probablethey take to the trees. So it was here, to a large extent. Nearly all the nests were in the woods. Some of them were placed at the foot of trees, or under spreading spruce saplings, but most of them were built in the tops of the spruces which grew usually only about twenty or twenty-five feet in height. When the nests were on the ground they were generally rather slight affairs, but on the trees they were very bulky platforms. The Gulls had brought load after load of grass and seaweed, till the mass was often large and firm enough to hold a man. At any rate some of them held me very comfortably while I gazed around over the floor-like top of the forest, and watched the Gulls wheeling about in the air. I could almost imagine how it felt to be a young Gull. Some of the nests were built in the upper crotch of the trees, others on 
the firm, spreading tops that grew into an almost solid platform.

By September the breeding season is nominally over, but on account of the pillaging of nests by fishermen, there were still a considerable number

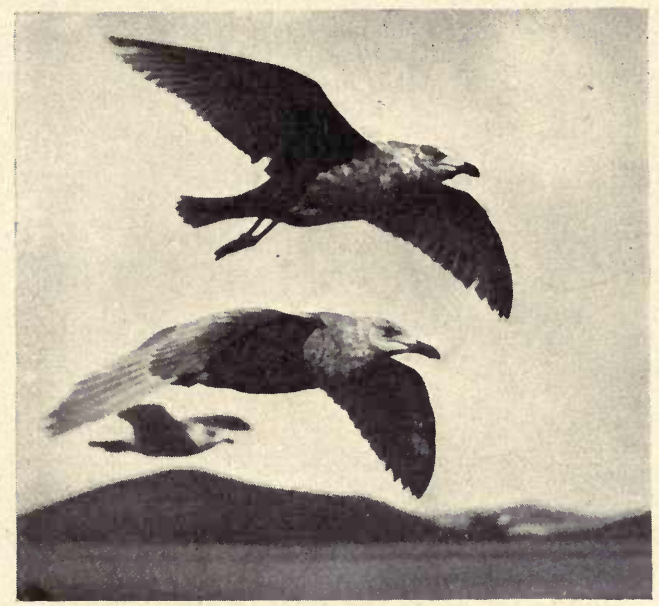

ANOTHER STUDY OF THE WESTERN GULL BY OTTO VON BARGEN

These studies were made in San Francisco harbor, where the large Gulls, - as a class ordinarly very wary, - have become, through protection, almost fearless of man, especially the immature individuals, whlch the photographs represent.

of the young Gulls not yet able to fly. They had all left the nests, having found some way, probably with the parents' help, of descending to the ground. It was a comical sight, those odd, mottled, partly downy, partly fledged, we bfooted creatures, as large as pullets, that were wandering about in the woods everywhere, pattering over the spruceneedle carpet, or else trying to hide by squatting under some bush or thick low growth. All the eggs were hatched that would do so, but now and then we found an addled one in the nest, a great dark drab affair, heavily spotted with black, larger than a hen's egg. I was struck with the similarity of the color and markings of the egg and of the young Gulls. The smaller youngsters looked for all the world like eggs with stilts stuck into them below, and a neck 
inserted on the end. And how ridiculously those seeming eggs lying on the ground would suddenly arise and scurry off at such a rate that one had to be spry to catch them! The colors blend perfectly with their usual surroundings on a pebbly shore, and this is the protection that the plan of Nature affords to all young birds of this class. Long before they become white, they can care for themselves.

A great many of the young Gulls had taken to wing, and large numbers of both dark, spotted young and snowy-plumaged parents everywhere we went were hovering overhead, often not more than fifty feet above us. Nor were they silent observers of our intrusion, for of all the noisy places on earth I do not know of anything that can equal a Gullcolony. Each bird seems to consider it a matter of Gull-morality to scream at regular intervals of not more than two seconds. When several hundreds, or thousands, are thus engaged, it would be deaf ears indeed that were not almost overpowered with the volume of sound.

The first Herring Gull colony that I ever saw was on Great Duck Island, Maine. In a dense fog we beat to it from Mount Desert, and went ashore in the tender. The Gulls bred mostly on the ground here, but some had taken to the trees. This was early July, and the nests, probably having been robbed, still had eggs.

For years I have loved to visit a fine colony of the Herring Gull on "No Man's Land," a lonely island far off the shores of Maine. Though the name truly represents its wildness, it is not accurate at the present time, for the island is under 


\section{The White-Winged Fleet}

human ownership, and the Gulls,-as now are the Gulls and Terns on all the principal breedingislands from Virginia to Maine,-are rigorously protected by law and by wardens. This is as it

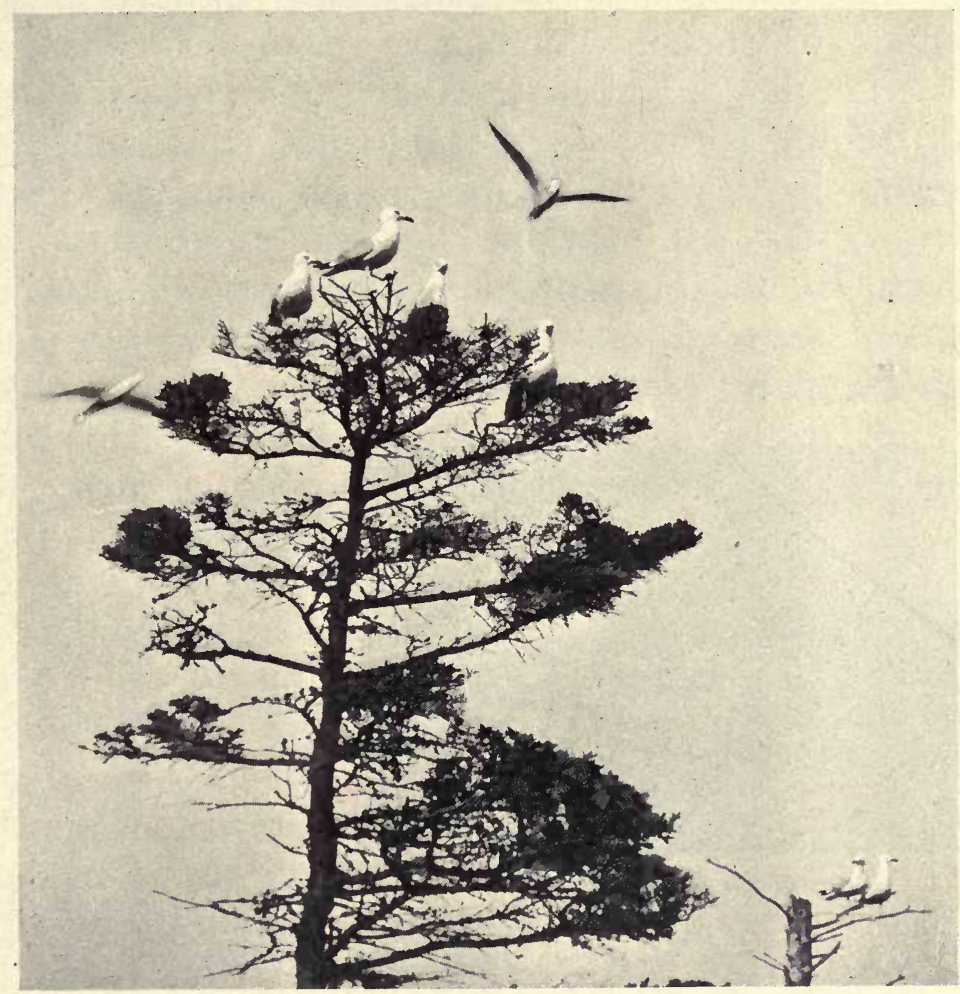

" OTHERS PERCHED UPON THE SPRUCE - TREES." HERRING GULLS, IN A MAINE ISLAND COLONY. BY W. L. BAILY

should have been long before. "No Man's Land" is another of the picturesque, rugged, spruce-clad islands typical of this coast. As we approach it, we begin to see a horde of circling birds, hundreds of them gathered in groups on the rocks, and others perched upon the spruce-trees. Then, 
running the tender up on a shelf of rock when the wave serves, all the thousand and more great Gulls hover screaming, or gather in groups on the dark trees, making a wonderful picture. Up above the rocks there is an area of pasture where graze a flock of sheep, which have been ferried over here for the season to live and multiply,- if they can. Some fail, as their dead bodies show, and the Ravens have plenty of wool with which to line their nests. All over the pasture, in all sorts of places, are the nests of the Gulls, deeply hollowed beds of seaweed, some quite slight, others substantial. Now we come upon one under a low spruce

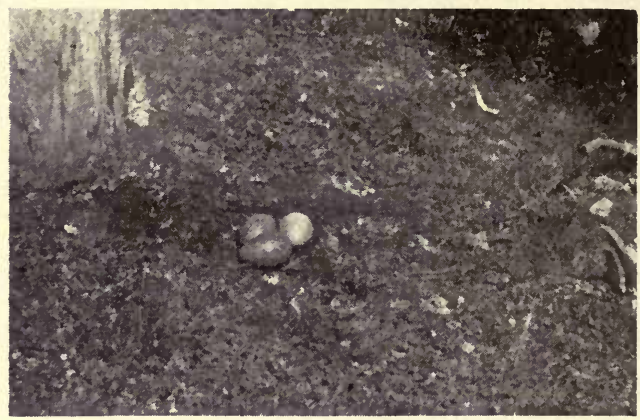

"ARE THE NESTS OF THE GULLS." NEST OF HERRING GULL, MAINE. BY A. C. BENT bush, then beside a rock, or boldly out in the open. Then we extend our ramble into the s p ruce-woods, and here they are just the same, all about on the ground among the trees. But, strangely enough, on this island I have never yet found a nest on a tree, though I know that the birds have been considerably disturbed by the fishermen. Most of the nests, unless marauders have been there, contain three eggs; often there are but two, and now and then four. They vary so greatly in ground-color and markings that it is fascinating to go all over the island and look at every nest that we can find. I recall one 
nest that had two very dark eggs, much the color of Loons'. Not far from it was a set of three, two of which, save for a few sparse spots, were pale bluish green. Between these types there are almost endless variations.

Not many miles from here is Matinicus Rock, notable for its great colony of Arctic Terns. This island has not the beauty that the spruces lend to "No Man's Land." Its very aspect is of desolation, and a reminder of the terrors of the forces of Nature as displayed in wind and storm. Even before we approach close enough to see the birds, the keen ear can detect above the roar of the surf that monotone into which the thousands of grating Tern-cries unite at that distance. Then we can see them in the air, and all over the old sea-beat rocks, literally thousands of them. At the time of my last visit, several years ago, I should say that there were from three to five thousand Terns, and the number is said to be increasing, now that the keeper of the light has been made a game-warden, and depredations upon them have largely ceased.

The keepers are very hospitable toward welldisposed people, and I have passed some very pleasant days there with them, studying the habits of the birds and looking at their eggs. It would hardly be correct to speak of nests, for few of them make what could by any charity be called such. Very many of the Terns lay on the bare rock, preferring, however, some little nook where a small quantity of soil or debris has found lodgement. Here and 
there a little vegetation has taken hold, - a few spears of grass, or a little clump of weeds. A slight hollow in such a place serves very well for a nest, and the addition of a few stems of grass or seaweed tucked around it for a rim, answers to give the owner the distinction of a wealthy house-owner and tax-payer.

Whether the distinction will ordinarily hold or not, I cannot say, but the Arctic Terns of this colony, and of others that I have visited, lay generally but two eggs, while with the Common or Wilson's Tern three is the ordinary number. On one occasion, when I looked the island over pretty carefully, and inspected hundreds and hundreds of sets of eggs, only about a dozen contained three eggs, and none more; the rest two each.

There is the usual interesting variety in the colors and markings of these eggs that there is in those of other Terns and Gulls, nor is there any perceptible difference between the eggs of the various species of Terns of the size of the Arctics. In these colonies I always like to look for oddly marked or colored eggs, and among so many some very strange types are found. On this island one season I found two eggs in a little hollow of the rock that were of a clear light blue ground-color, with only a few sparse spots. The next year, in the very same place, were two precisely similar eggs. A daughter of one of the keepers gave me a plain bluish green egg without a single spot, which she had found in a previous season.

The Terns were all over the Island, except at the southeast corner, near the cluster of buildings; 
but within a hundred feet or so of these we began to see eggs. The birds kept up their clamor all the time, and hundreds were ever in the air; but when we came from the buildings and began to invade the territory which they regarded as their own, practically the whole colony rose and hovered about, redoubling their vociferations. Now and then one would swoop close to our heads, evidently the owner of the eggs over which we were stepping. And so it is at all Tern colonies. It is bewildering, and always fascinating. No matter how many colonies I have visited, I am always ready to see another. The whole surroundings, of birds, and rock or sand and ocean impresses one with the vitality of unalloyed Nature, a scene of abounding, exuberant life.

How eagerly the faithful custodians of the lights on these lonely isolated spots look forward to the return of the birds, we may readily imagine. Were there no other calendar, the Terns could quite accurately supply one. They are very regular in their coming. At the time of my last visit the keeper told me they arrived in a large body that year on May I4, and laid the first eggs on the 28th. The season preceding, their date of arrival was May I7, and from these dates, I am told, there is little variation. He did not have the exact dates of departure, but from my observation with other colonies I should say it was not later than early September. As soon as the young are on the wing, they begin to scatter, and when the tardier ones can fly, they are soon gone. In one colony I found a few young on the rocks the first of September. But before that month has sped most of the Terns have 
left the New England shores, though some linger later, and I once saw a Tern- of the common species I took it to be-on Christmas day.

The common or Wilson's Tern is our most abundant species, very similar in habits and appearance to the Arctic Tern. It was years before I could tell them apart, and no one can always feel sure. The former kind has a paler bill, with black at the tip, while the bill of the Arctic is all of a dark coral red, and its breast is usually darker than that of its relative. What a delightful panorama it brings to my mind to recall the various breeding colonies of this species that I have visited! Some were on various rocky islands of the coast of Maine, and suggest scenes of sunshine and fog, breeze and storm, wave and calm; others were at the Magdalen Islands - small groups of a dozen pairs or so

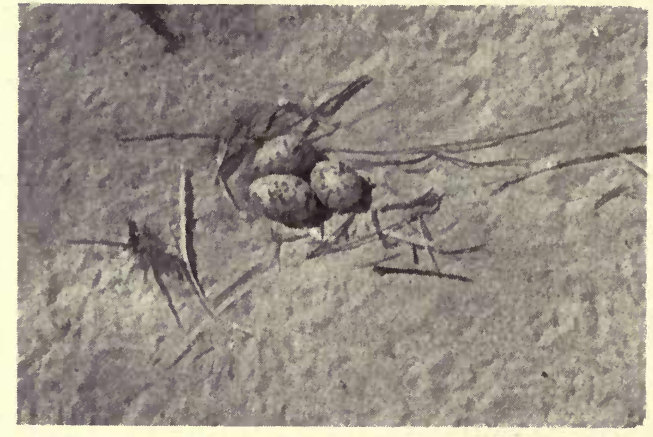

" CONSTRUCted With all grades of MEChanical ART, FROM A BARE HOLLOW IN THE SAND." NEST OF COMMON TERN, MAGDALEN ISLANDS

on numerous little islands in the ponds, and especially one great a rea of sand between the outer beach and the lagoon, where nests were scattered along for miles, constructed with all grades of mechanical art, from a bare hollow in the sand to a substantial bed of grass or seaweed. Along the beach at this locality were feeding immature Herring, Great Black-backed, Glaucus, 
and Bonaparte's Gulls, whose presence certainly enlivened the scene for me.

Off the southern shores of Massachusetts there are various sandy islands on which these Terns and others breed. One of these others, not yet spoken of, is the beautiful Roseate $\mathrm{Tern}$, very similar in appearance and habit, breeding near and even among the other spe-

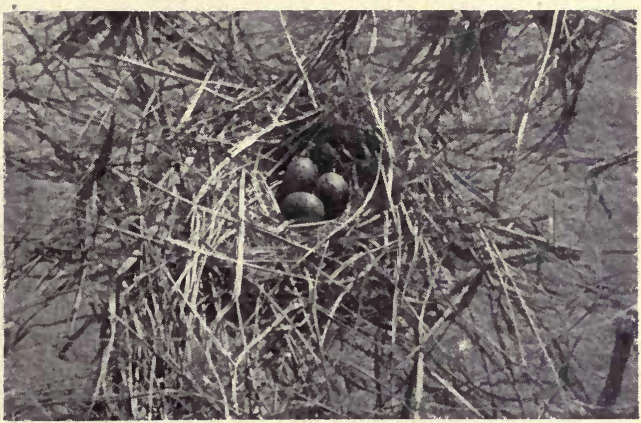

"TO A substantial BED of GRASs." ANOther Nest OF COMMON TERN, MAGDALEN ISLANDS cies, but distinguishable by its slender form and long tail, and a very white breast, that in the right light shows a beautiful pink blush of a most delicate hue. Any adjectives that I could use would be far inadequate to describe the grace and beauty of the Roseate Tern.

In the same habitat, from Massachusetts southward, is found that dainty little sylph, the Least Tern. I first saw it along the broad, lonely ocean beaches of the "back-side" of Cape Cod. There, as we walk along, several little Terns, much smaller than the other kinds, hover rather high over or beyond us, uttering their shrill staccato "yip, yip, yip." After a good deal of tramping, keeping our eyes painfully upon the blinding glare of the dry, sandy expanse back from high-water mark, we may now and then detect two, or occasionally three, little eggs that look almost exactly like the mottled peb- 
bles, lying in a slight hollow that is unlined, except sometimes for a scant bed of little chips of musselshell. These are the Least Terns' nests.

Previous to the departure of the Terns from us in the autumn, they are everywhere flitting about our shores and bays, following up the schools of small fish and resting on sandbars, flats, or even

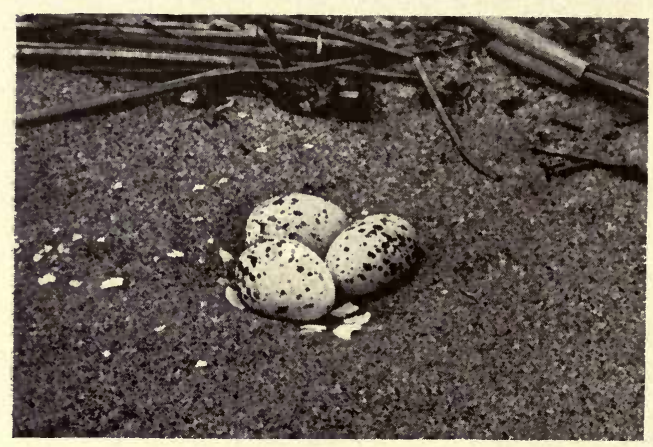

“THREE L:TTLE EGGS THAT LOOK ALMOST EXACTLY LIKE THE MOTTLED PEBBLES, LYING IN A SLIGHT HOLLOW THAT IS UNLINED. EXCEPT SOMETIMES FOR A SCANT BED OF LITTLE CHIPS OF MUSSELSHELL." NEST OF LEAST TERN. BY W. H. FISHER

boats, buoys or $f$ is hermen's traps. Old and young are inter$\mathrm{m}$ ingled, and they are tame and gentle. To bays where there is good fishing they will resort daily, flying out s e a w a d a t night.

The Herring Gull is the only true Gull that nests on the coast of Maine. From Massachussetts southward the Laughing Gull nests sparingly on sandy islands and marshes, often near colonies of Terns. The other species of the Gulls are more northerly than either of the above. Immature individuals linger far south of the breeding-range of the species. So when one sees more or less mottled Great Black-backed, Glaucus, or Bonaparte's Gulls in summer, do not imagine that their nests can be discovered by any amount of search.

Early autumn begins to bring the Gulls to us 144 
from the north. By the middle of August, among flocks of Terns we can often pick out a bird or two of heavier build, square tail, and slower flight, that proves to be Bonaparte's Gull in winter dress, without the striking black hood. By September, or even earlier, our familiar Herring Gull begins to return south from the breeding-grounds. If we look carefully we may notice a very similar Gull that is a little smaller, known as the Ring-bill, which, in the coast-region, goes in summer far to the north. In late fall the beautiful Kittiwake becomes abundant well off shore on the fishinggrounds, and the big fellows appear,- the Great Black-backed, which becomes fairly common, and the rare Glaucus Gull, or Burgomaster.

I well remember when I first saw the "Burgomaster" alive. I was watching a flock of Herring Gulls feeding just off one of the Boston docks in midwinter, when I became aware of the presence of a larger individual, a magnificent Gull, white all over, without even the black wing-tips of the others. With them it was hovering, wheeling, and alighting to pick up morsels from the water, no more fearful than they. There was no doubt as to what it was, and I watched it for an hour before it went down the bay. Its spread of six feet across the wings gave it an impressive appearance.

This is the size also of the Great Black-backed Gull, that is also known as Turkey Gull, Minister Gull, and by other names. The black plumage of its upper parts in contrast with the pure white below makes it, in the adult phase, very conspicuous. But it is one of the shyest of birds. The Herring 


\section{Among the Water Fowl}

and Ring-billed Gulls are ordinarily shy enough, except by wharves, where they seem to know that there is no shooting allowed. But the sable-backed fellow never relents. I have, in years past, exhausted all my ingenuity in vain efforts to get near one.

A good glass, however, makes even these various large shy Gulls seem near, and I love to watch and study them upon our coasts in winter under the various conditions: on restless wing and with keen vision scouring the ocean for food, tacking in the teeth of the winter's gales; settling in flocks upon the wind-swept sea, out beyond the breakers; gathering on the beaches and flats when the tide goes down, where they walk about with sedate bearing, and stoop to conquer the juicy bivalves or the luckless crustacean; sitting on the edge of some field or drifting cake of ice, the very incarnation of Boreas. These are all typical sights.

To study the Gulls further, let us make a journey in thought, westward to North Dakota, that paradise of water-fowl. There I will introduce the reader to some islands in a large lake. They are nothing but small, low, rocky shoals, of very little beauty in themselves. But I call them "The Enchanted Isles," for there are more kinds of waterbirds breeding on them than on any other small area that I have ever seen. It was only accidently that I learned of their whereabouts three years ago, through one who, not a bird-student, tarried awhile in this, the lake region of North Dakota. In all 
I have paid them half a dozen visits, and every time have seen something new.

I will describe a visit to them made this past season: It was the last day of May, a splendid morning, calm and bright. Two of us there were, and we had come two thousand miles to see the birds, making our headquarters in a small shack with a hunter who was to drive us to various interesting places. The islands were about eight miles from here, and at seven in the morning we started out in a rather novel fashion, a pair of broncos hitched to a buckboard, upon which was loaded a substantial keel row-boat, in which we sat with our cameras and various equipments. Thus we voyaged over the prairie in our boat that was propelled by horse-power. A pack of hunting-dogs followed us, and amused us by catching gophers and chasing jack-rabbits. In the latter case, the quest was never successful. Not even the greyhound seemed able to catch such a marvellous runner as "Jack," so long of limb and nimble. On these drives we now and then saw a badger by its hole, or a gaunt gray coyote, or prairie wolf, loping over the prairie, stopping now and then to look back at us.

So we drove along, exhilarated by the wild scenery of the prairie, and the crisp, stimulating air. Reaching the lake, we unloaded our boat on the beach, and, after tethering out the horses, pushed off, heading for one of the four low islands that lay over a mile out in the lake. As it became plainer to our vision, the first signs of bird-life were dots all over the rocks, that I knew to be mainly Ring-billed Gulls, and rows of black objects 
that represented a fine colony of Double-crested Cormorants. The latter were squatting or standing upon their nests that were placed as close together as possible, resembling in the distance troops of soldiers in martial array.

When we approached within quarter of a mile they began to fly off in detachments of a dozen or so at a time, to alight out in the lake and watch us. Then the Gulls began to get uneasy and at length, with a great fluttering, the whole colony rose. The air was filled with beating white wings and with an almost deafening clamor. There is no bird more

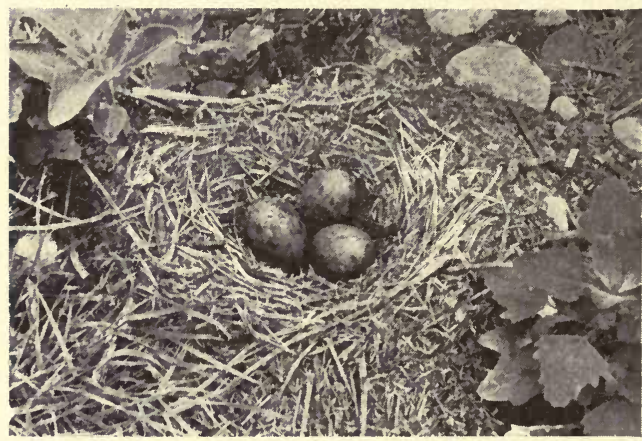

"NO SOONER HAD WE ADVANCED A FEW STEPS FROM THE WATER'S EDGE THAN WE WERE IN THE MIDST OF EGGS OF THE GULLS." NEST OF RINGBILLED GULL capable of noise than a large Gull, and every one on this island performed faithfully its part.

Then we landed, and no sooner had advanced a few steps from the water's edge than we were in the midst of eggs of the Gulls. The island's surface was more or less covered with loose stones, with some grass growing on the summit. The Gulls' nests were anywhere and everywhere, among the stones, besides clumps of weeds, in the grass, rather slight affairs consisting of a rim of dry grass or weed that seemed to deepen the slight hollow in the ground, which was lined with a few feathers. 
Nearly all the nests had three eggs, but occasionally there were but two.

The island was very small, hardly more than an acre in extent, so that it was not hard to estimate the population. We counted just about an even hundred nests with eggs, besides a number more that were empty. Some had probably been robbed, and I think it safe to say that there were three hundred birds belonging on this island. There was about one pair of Herring Gulls for ten of Ring-bills. The eggs of all had evidently been laid the middle of May, and there were no young yet hatched.

Meanwhile we had also investigated the homes of the Cormorants, and a most interesting sight it was. The nests were good-sized platforms, built very ingeniously of crooked sticks that were so interwoven that the nests were often substantial enough to be lifted up without falling apart. In fact, we once found a nest on the shore of the mainland that

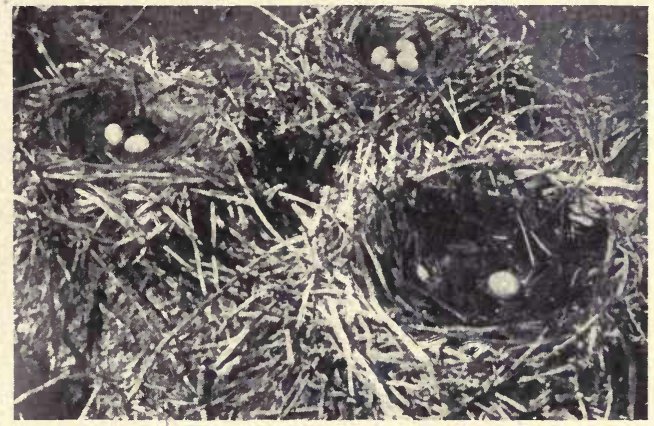

" THE NESTS WERE GOOD-SIZED PLATFORMS, BUILT VERY INGENIOUSLY OF CROOKED STICKS." NESTS OF DOUBLE-CRESTED CORMORANT3. THE NEAREST HAS IN IT TWO NAKED BLACK YOUNG THAT HARDLY SHOW IN THE PICTURE

had either been carried or drifted there, and yet was intact. There were seventy-three nests in all, in two about equal areas, one down by the shore, the other well up on the higher part of the island, but not far away. In each area the 


\section{Among the Water Fowl}

nests were placed touching one another. Nearly all of them held three or four very rough-looking, dirty white eggs, that seemed to be covered with a sort of chalky deposit, which can be scraped off, when a harder bluish shell is exposed. In one nest there were six eggs, and on previous visits $I$ had seen seven and eight. Many of the eggs seemed fresh, but in a few cases one or two young had hatched. I doubt if there is in bird-world anything uglier than a young Cormorant, blind and naked, with a slimy looking black skin.

My companion and the guide now rowed off to the next island, while I remained to see what I could do at photographing the Ring-billed Gulls, which I noticed settled on their nests whenever we kept out of sight. I selected a spot where there were a number of nests quite close together, just above the top of the beach. Here was a sort of windrow of stones, piled up by the waves, just near enough to the nests to be useful. Removing some of the stones, I made a level spot for the camera, focused it so as to take in half a dozen of the nests, covered it with the cloth, attached the spool of strong thread and set the shutter, then piled up stones around and upon it, except in front. Carefully I unwound and laid the thread along the beach nearly the whole length of the 200-yard spool. To where the thread ended I brought the old sail, and lay down under it. After some hovering the Gulls began one by one to alight, until at last there seemed to be quite a number of them in front of the camera. I was too far away to see just when things were at their best; but, as general conditions 


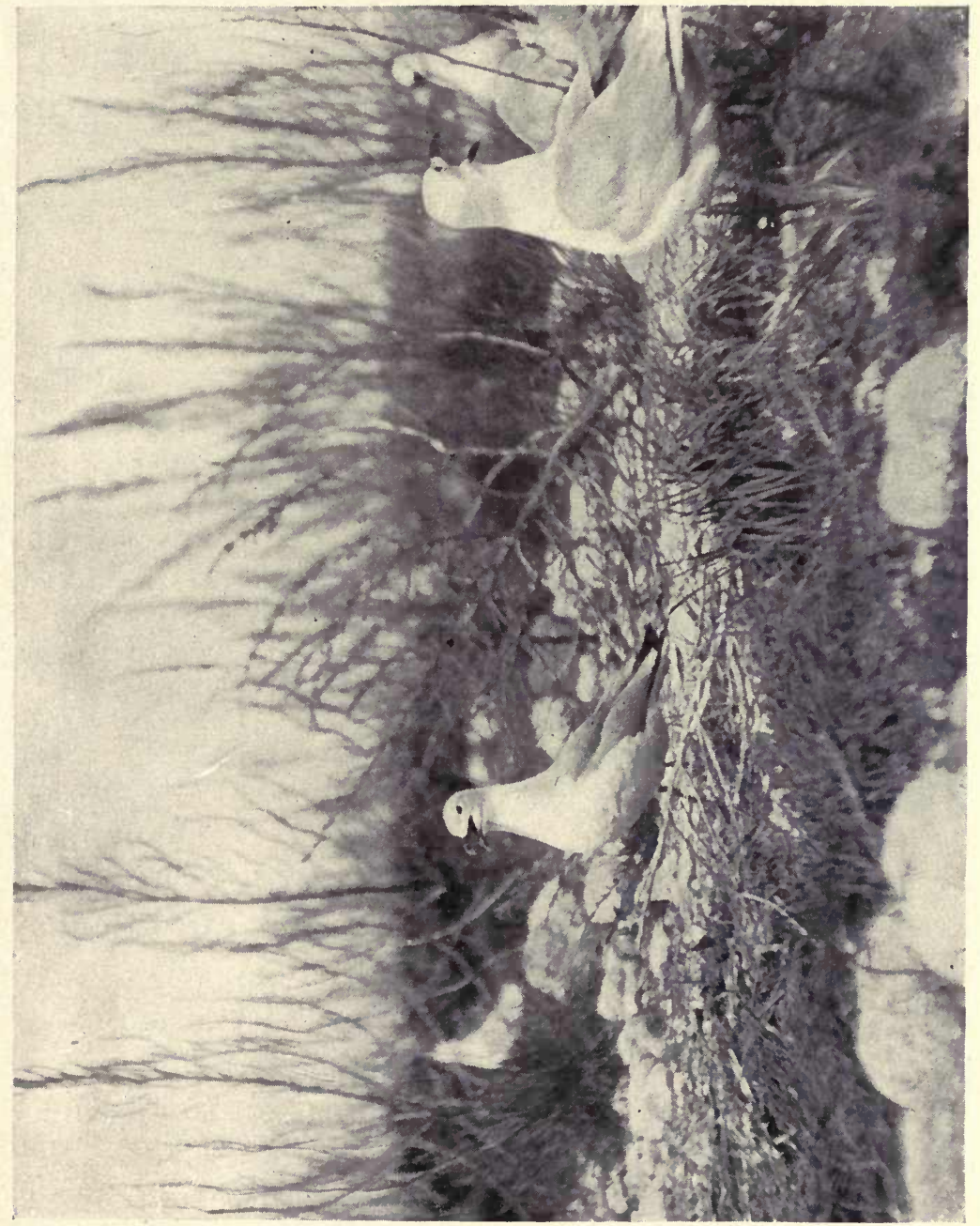

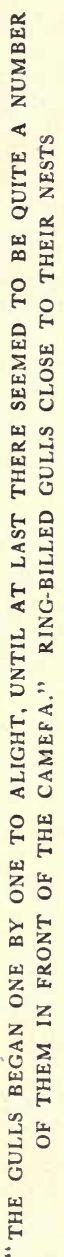


were propitious, I drew in what slack there was and pulled the thread taut. The Gulls showed no signs of having heard the shutter, but it had sprung all right I found

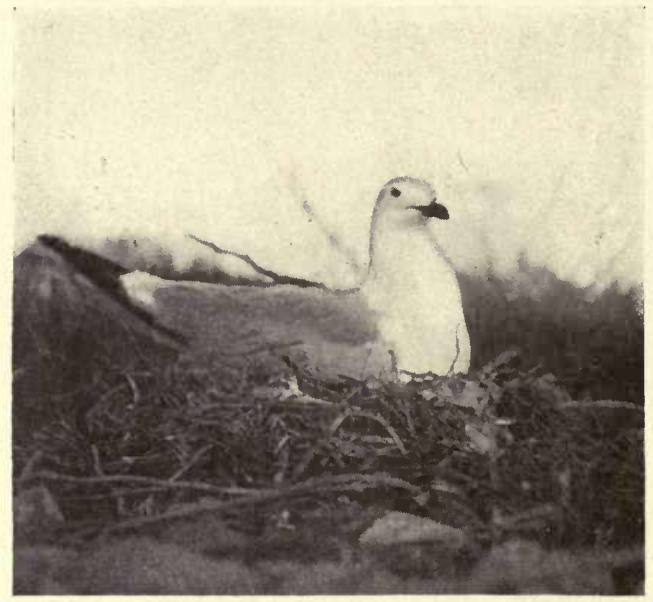

"THEN FOCUSING ON A SINGLE NEST AT CLOSE RANGE" RING-BILLED GULL ON NEST

when I walked up.

In the same manner I proceeded with the work, taking a few more shots from the same position, then focusing on a single nest at close range, or on a couple of nests, and again on a rock where the Gulls frequently alighted. In the latter case I got a fine exposure on two birds on top of the rock. The Gulls soon became much more confident, and would return to their nests as soon as I retired, often standing so near the camera as to brush against it. Of course the exposures had to be instantaneous, and cloud areas bothered me a good deal. The Cormorants proved to be too shy to be photographed. When the boat returned with accounts of wonderful finds on the other islands, all too soon for me, I had what proved later to be a very interesting series of Gull pictures, the fruits of a hard day's work. If anyone thinks it easy, I would like to put him on a glaring beach in a broiling sun, without a trace of a breeze, surrounded 
by bird-filth and swarms of insects, and given the nests of some rather shy Gulls and a camera, let him try it, and see if he could keep his temper when the string became snarled, and how many fogged plates he would get.

On June I5, the weather calm and cloudy, we again visited "The Enchanted Isles," four of us this time. We took some more pictures on the same island, and then rowed to the next two, that lay together a mile away . There we had enough to occupy us the rest of the day. These islands were each considerably larger than the other, and were teeming with bird life. The first of them had

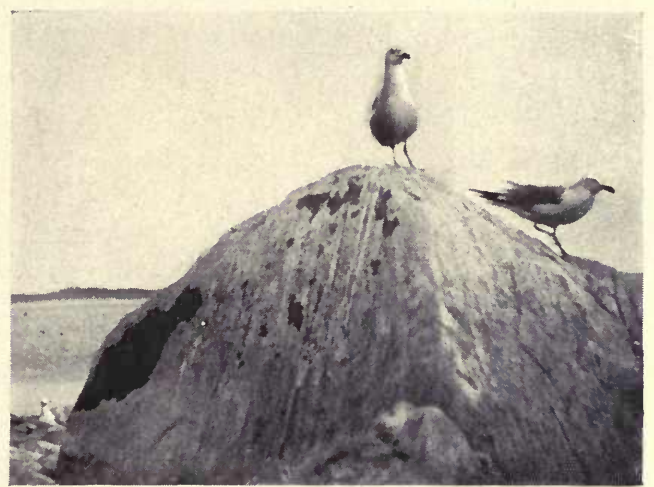

"I GOT A FINE EXPOSURE ON TWO BIRDS ON TOP OF THE ROCK." RING-BILLED GULLS ABOUT TO RETURN TO THEIR NESTS

on it quite a colony of Common Terns, the second a much larger one of Terns, and quite a number of Ring-billed Gulls, perhaps a hundred of the latter. The Terns had their sets, usually of three eggs, everywhere about-above the beach, among the stones, and in the grass. We photographed a great many nests of various sorts, and it was well that we did it early, for about the middle of the afternoon the sky grew very dark, and a furious rain set in. Fortunately, we were well pre- 
pared for it, with coats and boots. We turned the boat partly over, put our cameras and accessories under it, and took refuge there ourselves. It was a fine outlook over the storm-swept lake. The rain, pouring down on its surface, splashed up jets and bubbles, and made the whole sheet of water white in its agitation. Frequently what amounted to almost a cloudburst would occur, and everything would be shut out from view, nothing remaining visible over the lake but a blinding sheet of descending water. This was very picturesque, and we enjoyed it for awhile; but when the moments grew to hours without a sign of slacking it began to get monotonous. Finally, at half-past six, we buttoned up our coats, covered up our cameras in the rubber cloths, and pulled out into the storm. Fortunately, the rain soon ceased, and after dark we reached the hospitable Dakota shack none the worse for a little wetting.

A week later we made still another visit to our enchanted islands. We began at the one not yet visited, and found there the usual pleasing variety of water fowl, and good colonies of Terns and Ringbills. Then we rowed to the third island. Terns and Gulls filled the air, and Ducks flew squawking away. It was a fine day, and I set the camera for a view of Gulls on the rocks, getting two exposures after a vexatious delay caused by one of the company innocently walking through my invisible line of thread, and getting it all tangled up in the weeds. Then, after photographing some nests, I tried my luck on the Terns. There were hosts of them all over the island, and they made a prodig- 


\section{The White-Winged Fleet}

ious and unceasing fuss over my presence, going on to their nests awhile, and flying up again without any seeming provocation. At first I thought that the task I had grappled with so confidently would find the day too short for its accomplishment. I set the camera in the sand, or grass, by sheltering clumps of weeds, near two or three nests, but the hovering birds provokingly would not go on, and I could not afford time for an indefinite wait. At last I noticed a set of

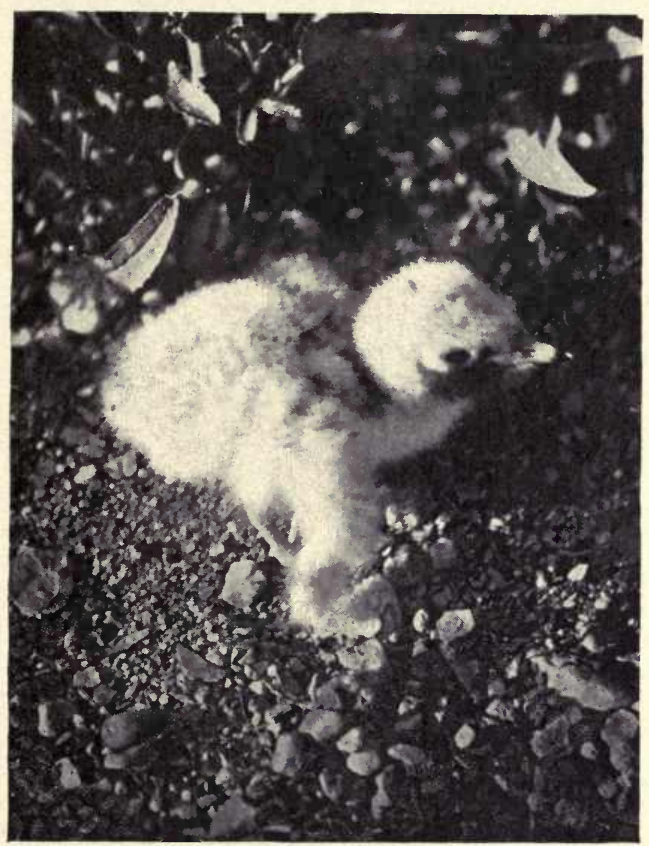

"I TRIED MY LUCK ON THE TERNS." YOUNG COMMON TERN

two eggs that were pipped, and I certainly thought the owner would brave the camera for them. So she did. With the thread in hand I lay down on the sand about fifty yards away. Within five minutes she alit close to the nest, and I got a picture, and soon another, as she was covering her eggs.

Quite a few of the Gulls' eggs had hatched. The young were skulking among the weeds and 
stones, or had betaken themselves, in small parties, for a swim out on the lake. Here I had it

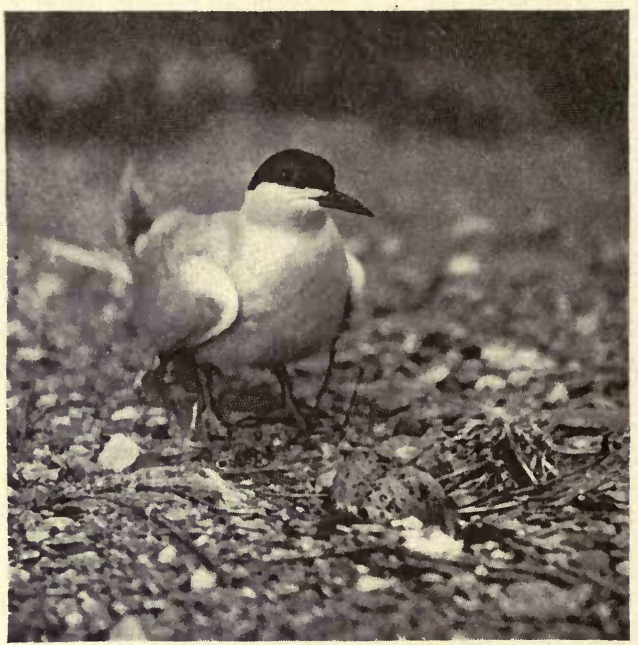

"WITHIN FIVE MINUTES SHE ALIT CLOSE TO THE NEST" COMMON TERN, ABOUT TO SETTLE UPON HER EGGS

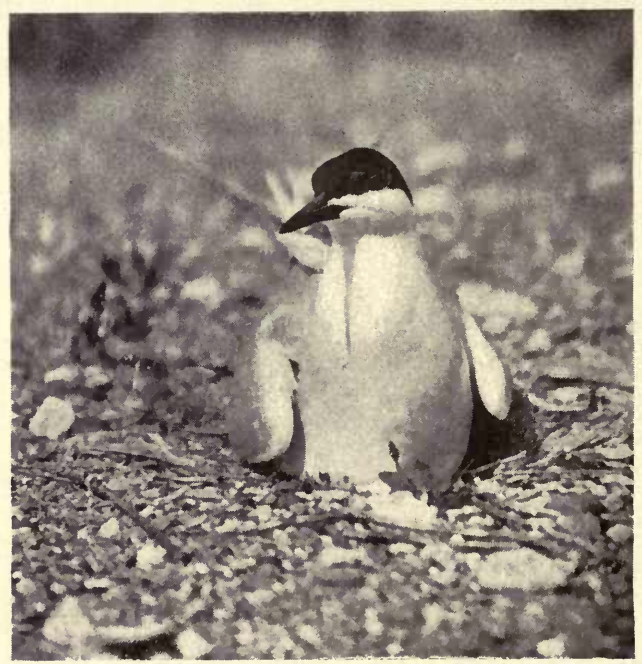

"AND SOON ANOTHER. AS SHE WAS COVERING HER EGGS" THE SAME TERN AS IN ABOVE ILLUSTRATION more impressed upon me than ever that these beautiful and innocent - appearing species of the Laridæ are not always in conduct what we $\mathrm{might}$ expect from appear ance. I noticed quite frequently that some Tern or Terns would angrily dive down at a young Ring-bill out on the water, and strike it some pretty hard blows. One of my friends, who returned there later in the season, saw Terns again and again strike a young Gull till the innocent head fell, and the bird lay 


\section{The White-Winged Fleet}

dead on the water. I also noticed, when I first visited the Cormorant island, that when the Cormorants were frightened off their nests, before they would return, the Gulls settled down upon their homes, and ate a number of the eggs. I have already recorded the case of the Franklin's Gull plundering the Grebe's nest, and it is evident that such deeds of vicence are a family trait among o u r beautiful and interesting friends. But with all their

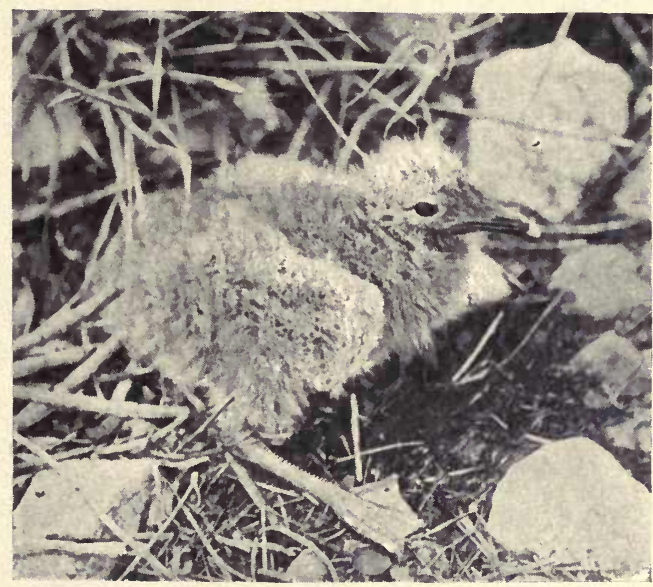

"THE YOUNG WERE SKULKING AMONG THE WEEDS AND STONES." YOUNG RING-BILLED GULL

faults we shall continue to love them, and refrain from flinging at them in cynical spirit, "handsome is that handsome does."

Among all birds, I do not know of a more beautiful species than the Franklin's Rosy Gull. It is of medium size, resembling Bonaparte's Gull in having a black hood, as it vere, over the head and the upper neck, with pearl-grey upper parts; but the under portions, which are white, have added a beautiful rosy blush. They are said to breed from Dakota northward to the Arctic sea. Besides being 
beautiful, they are interesting in being illusive. All over the prairies they straggle, in small groups or in large flocks. The settlers call them "Prairie Pigeons," and I know of no more unique and beautiful sight than to see a small army of them follow the farmer as he ploughs, dropping into the newly turned furrow behind him like snow-flakes, to pick up the worms and grubs that are exposed to view. In places, especially near their breeding grounds, I have seen the prairie fairly white with them.

But their breeding grounds? - that is the question. It is their habit, according to accounts, to congregate in immense numbers in some large shallow lake and build floating nests amid the grass and reeds that grow out of the water. There are certainly not many of these colonies within our borders. There may not be more than one or two in all Dakota, in spite of the fact that so many birds are wandering about. Many a time I have watched them as they came drifting over the prairie, ever on the move, and have longed to know whither they were journeying. I could not locate their breeding ground from the direction of their flight, so I wrote to different parts of the state, and questioned every Indian or hunter that I met, but it was of no use.

At length, through hearsay and rumor, I traced out the fact that a year or two before great numbers of these Gulls had nested in a large, deep slough, north of Devil's Lake. The Sioux Indians, it was said, were accustomed to go there and cart away eggs by the bushel. I reached the spot after 
a considerable wagon journey only to find that the Gulls had been so persecuted that they had not returned that season, but had moved off somewhere else. This was very disappointing, and to this trial was added being caught on the return trip in the most terrific thunderstorm I was ever out in, or ever wish to be. The wind blew over houses, and the rain almost filled the body of the wagon. If ever we were soaked it was then. We had to sleep in a barn that night and two nights more ere we got back to headquarters. Much further search had already been in vain.

This only served to whet my desire the more for the Franklin's Gull, and when I decided last season to visit Dakota again, I redoubled my inquiries. Finally I heard of a young man who probably had the desired information. Imagine my delight when I received one day a note to the effect that he knew of a large colony of thousands of the Franklin's Gull, and would guide me there if I would come to his house.

At the earliest possible moment we started off, three of us, with broncos and buckboard,-this time without the boat,- for the drive of fifty miles. The site the Gulls had chosen was at one end of a large lake a number of miles long. At length we approached the timber on its margin. On the left a settler was ploughing, and about twenty Gulls were following him close behind, and feeding in the furrows. On the right, down a steep bank, lay the lake, a long area, over a mile wide, with some open water and grass growing from it in extended tracts. The distant murmur of many bird-voices 


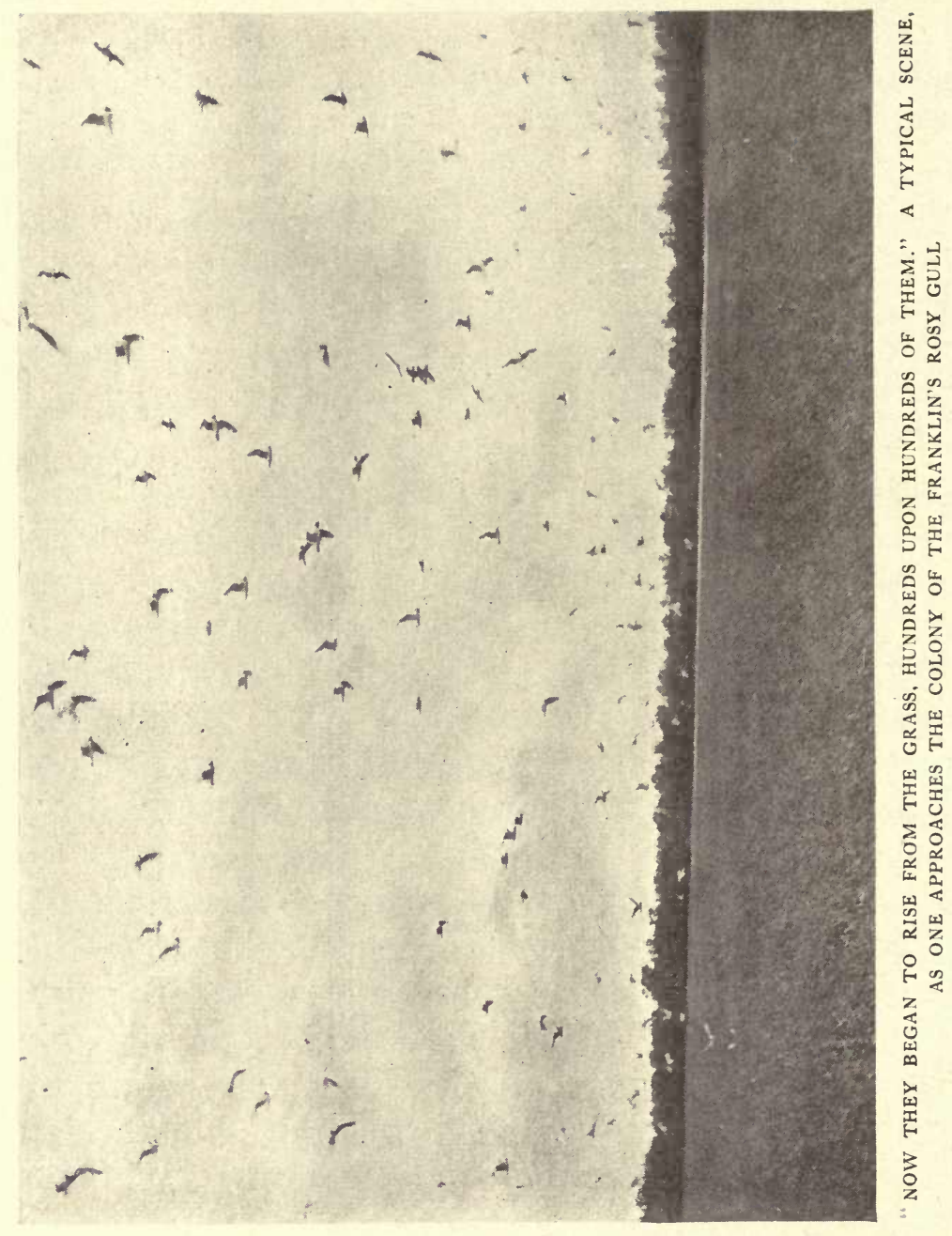


came to our ears, and we could see hundreds of the Gulls in the air out over the middle of the lake. By the time the others had pitched camp in the timber our young guide and I had secured a boat, of which he knew, and we all sallied out, poling through the grass. We passed various Coots' nests and hovering parties of Black Terns, when about quarter of a mile out, crossing a wide lane of open water, we approached a tract of the long, coarse grass growing out of four or five feet of water, where the colony began. Not a great many Gulls had been in sight, but now they began to rise from the grass, hundreds upon hundreds of them, yes, thousands. The clamor of the nearer ones started those farther along, and even away off in the distance we could see clouds of fluttering white wings. The nearer ones immediately came toward us, and hovered screaming over our heads. The scene, as far as number of birds was concerned, was the only one I have witnessed that could rival Bird Rock. At times part of the multitude would come together in an unusually compact mass, and circle about us.

Here were

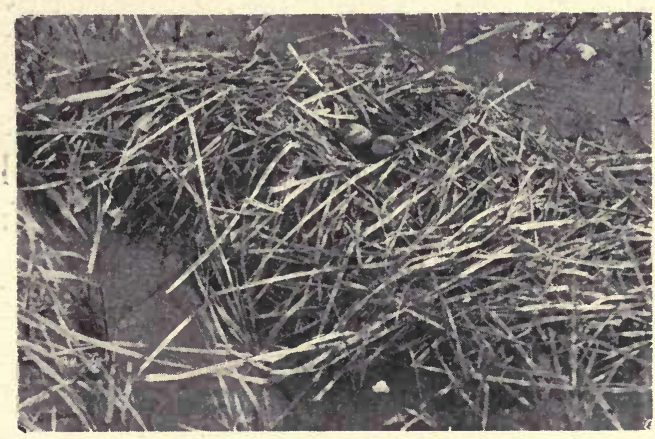

"HERE WERE THE NESTS, RUDE FLOATING PlatForms OF DEAD GRASS STEMS." NEST OF FRANKLIN'S GULL

the nests, rude floating platforms of dead grass stems, only slightiy hollowed, a few feet or 
yards apart, everywhere through the grass. The date was the $25^{\text {th }}$ of June, and most of the eggs had hatched. Tiny young Gulls in a mottled, downy plumage were paddling through the grass in all directions. Our conductor had been here about the $25^{\text {th }}$ of May and had found all the nests

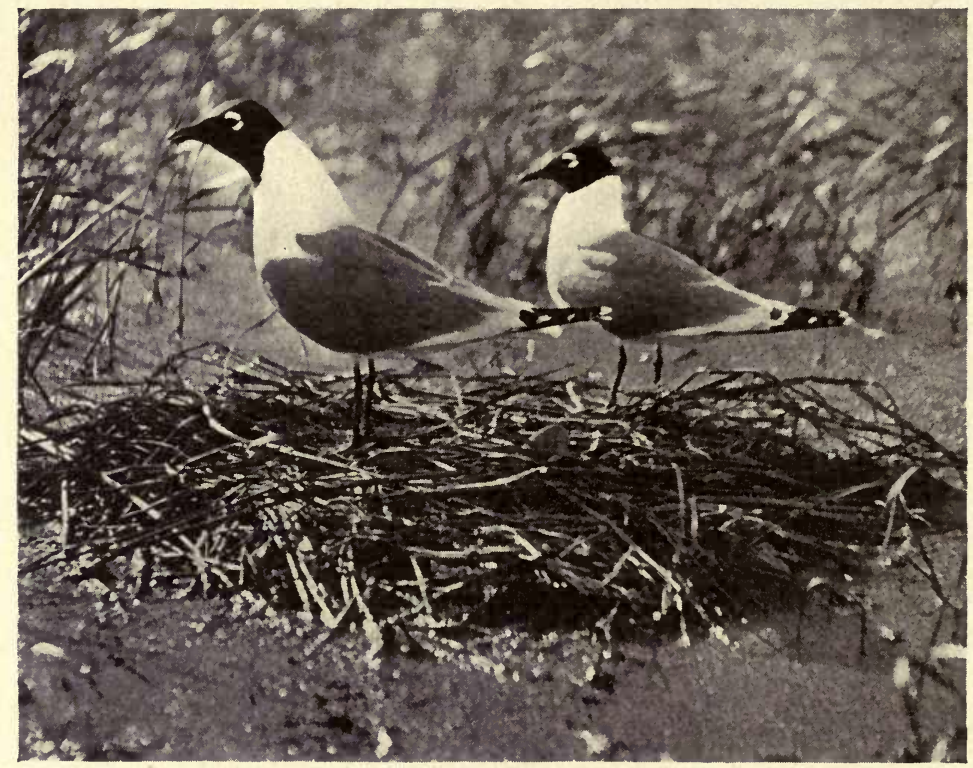

PAIR OF FRANKLIN'S GULLS ON THEIR NEST, WHICH CONTAINS ONE EGG; TWO OTHER EGGS, PROBABLY, HAD HATCHED AND THE YOUNG SWUM OFF

with full fresh sets, usually of three eggs. Very few nests now had three, but quite a number had one or two, probably either second layings or where part of the set had hatched and the young had swum off. The eggs were like those of all Gulls in color and markings, in size about half way between the eggs of the Common Tern and the Ring-billed 
Gull. One of the first nests we noticed had two eggs notably smaller than any of the others. We thought there might be a pair of Bonaparte's Gulls among the Franklin's, but to our eyes the excited, hovering creatures all looked exactly alike. They were plenty near enough for observation, hovering fearlessly only a few yards away from us.

We spent three more days by and among the colony, and, despite daily showers, I was able to observe and photograph them very satisfactorily. At times I took the boat alone, and quietly floated in the grass, with nests all around me. I believe I could stay there for weeks and enjoy associating with those beautiful birds. They were so tame they would alight on their nests when I was within ten feet of them, and I took various snap-shots with the camera held in my hands. Some of them were incubating, many others standing on empty nests, from which the young had swum off, usually to return as soon as confidence was restored. But, as nearly as I could decide, the young were not at all particular as to just which nest they resorted to. Some mothers would have but one chick, others at times half a dozen. Often the "one ewe lamb" would swim off to another nest, to be just as hospitably entertained. In some cases the old bird would fly at the departing youngster and make vigorous efforts to head it back again, usually without success. It would seem that the tribe, to a considerable extent, "had all things common." Now and then groups of the adults would gather in a little open pool of water and swim about, but the nests seemed to be the especial places of resort. 


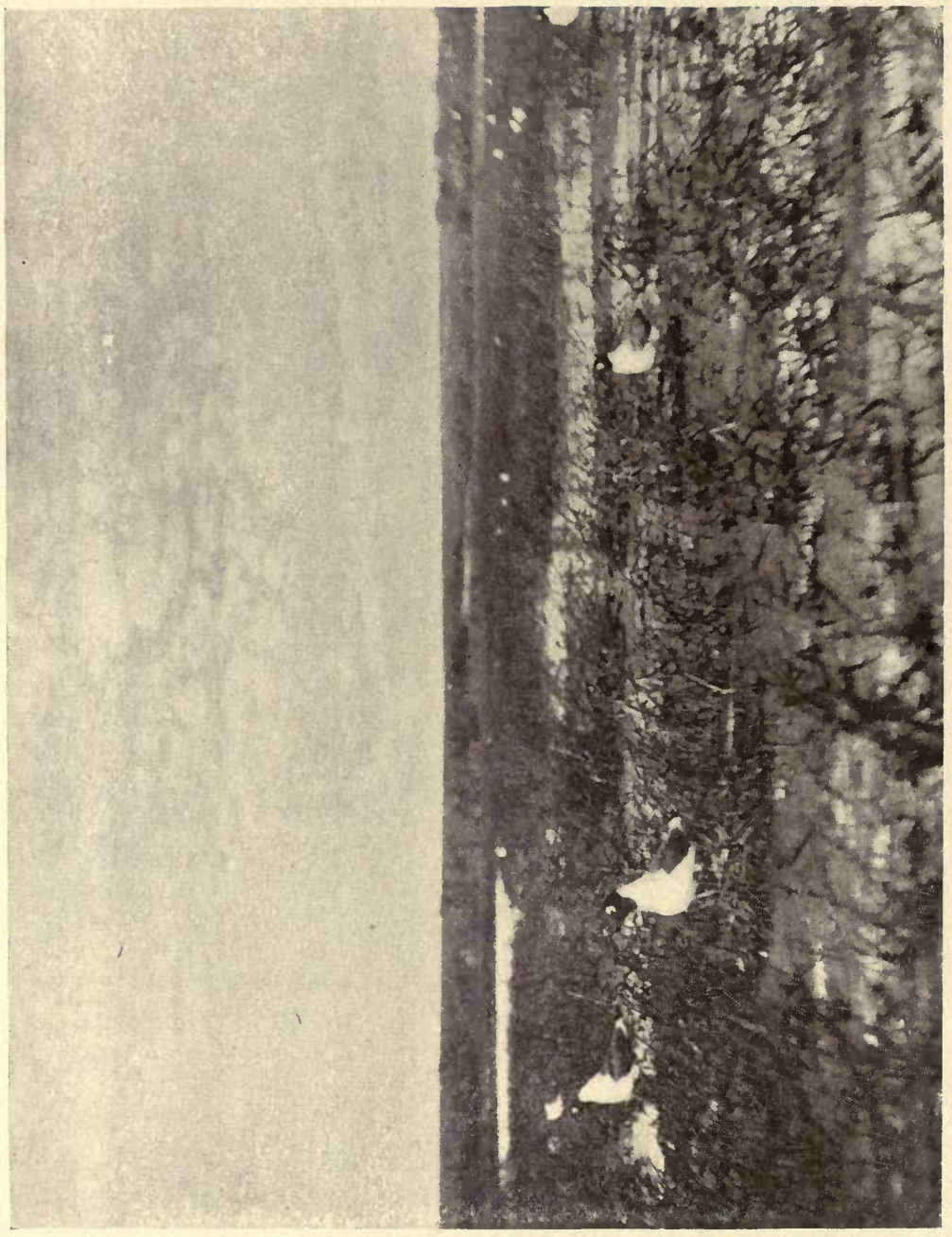

존

z 0

空

- I

뇌 뇓

3

in

की

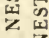

똑

F

깅 임

点咥

안

\&

곤

인

z

$>0$

प्र क

린

된일

近

\&

(1)

노

㟧 


\section{The White - Winged Fleet}

Even at this late date various members of the colony were flying in with long streamers of grass in their bills for the repair of their nests, that they might continue to serve them as roosting places.

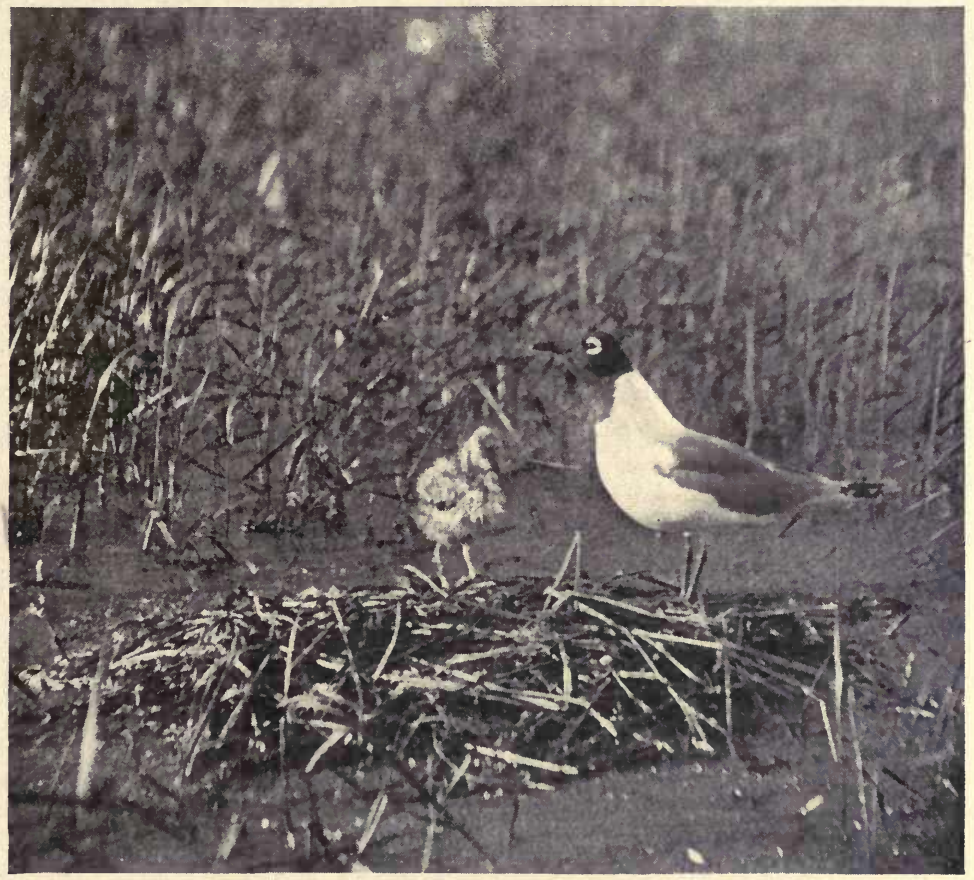

A FRANKLIN'S GULL FAMILY SCENE

During these days we carefully explored the whole colony. It seemed mainly to lie within half a square mile, comprising three main areas, one in the middle of the lake and two nearer either shore, separated from the central portion by lanes of open water. There were other subsidiary parts as well, making the occupied area of considerable size. As a rough and very conservative estimate we placed 
the probable number of Gulls at about five thousand, though one of the party thought it was nearer ten thousand. Whatever it was it is a wonderful sight, and those days spent there in camp will be of fragrant memory. At night I would look out over the moon-lit expanse and hear the clamor of the colony that appeared to cease not day nor night. Possibly at night the Musk-rats or Minks were disturbing them.

This lake was a wonderful center for bird-life. Besides Coots, Rails, Night Herons, Bitterns, large numbers of Ducks, and about a thousand of various kinds of Grebes, some of them in colonies, we estimated that there were something like a thousand Black Terns breeding. These we found hovering in flocks wherever we went in the area of water-

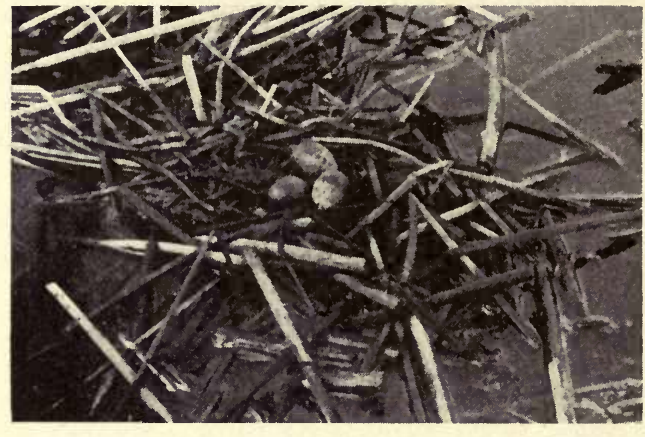

"IT WAS NOT HARD TO FIND THEIR NESTS, WHICH WERE LITTLE MOUNDS FLOATING IN PARTIAL OPENINGS AMID THE GRASS." NEST OF BLACK TERN growing grass that extended in a wide border out from the shore all around the lake as far as we went. It was not hard to find their nests, which were little mounds floating in partial openings amid the grass. They were not close together, but in occasional little communities, being placed there a few yards, or even rods, apart, perhaps a dozen or so to a group. Two eggs are usually laid, some- 
times three, and in one case I found four. They are very heavily marked and scrawled with black, so much so as almost to hide the ground-color. These little Terns are late in breeding. At this time many of the eggs were quite fresh, and some of the sets were incomplete, though there were some young swimming about in the grass, after the fashion of their family.

They are bold and noisy little fellows, especially when they consider that their rights are being trespassed upon. On one occasion, after photographing a nest with three incubated eggs, I noticed some young in the water, and, climbing out of the boat, waded after them. The water was just up to the top of my boots, and I found that I must hold these up to keep dry. Then the motherbird made at me with all her might. With angry swoops she kept striking me most vicious blows on the top of the head with her sharp little bill. At first I laughed, but I had on only a very thin cap, and having to hold up my boot-tops all the time, I could not protect myself. Finally my head pained me so that it was no laughing matter, and I actually had to beat an inglorious retreat and climb into the boat, - a man worsted by a tiny little bird with nothing but a bill for a weapon. For all that, I could not be angry at the little mother, but admired her courage and strength. It made me think what would be the result if all the birds in that teeming slough should combine for a bold attack on the visiting ornithologists.

This little Black Tern is one of the most typical birds of the Dakota prairies. Almost never 
have I approached a grassy slough in the breeding-season without finding them in evidence, and wherever one drives on the bare dry prairie, sooner or later the little dark friend is almost sure to put in an appearance.

For convenience, though it is not scientifically one of the Gulls, I may, in this connection, speak of a bird that is related to them, and in some ways resembles them, - the great White Pelican. I have never discovered their breeding-place in Dakota, which is said to be some low island in a lake, where they lay three or four great white eggs in a hollow in the sand. But we found them frequenting most of the large lakes that we visited. The size of the bird is impressive. I think that, perhaps excepting the Swan, it is decidedly the biggest bird of North America. It is nearly as tall as a man, has a stout, heavy body, and enormous bill, and a stretch of wings of between eight and nine feet. Riding out on the lake, they look almost like yachts at anchor. Such size makes them appear near even when they are really far out from shore. It was a fine sight one day when I saw seventy of them in a V-shaped flock, soar over a lake and circle down till they rested upon the water.

One of our company was anxious to secure a Pelican for his cabinet, and at last he saw a chance to approach one perched on a rock a little way out in the lake. A calf that was determined to. follow him and see the sport very nearly prevented his success, but he managed to stalk and secure the great bird. It was a sight indeed to see him 


\section{The White-Winged Fleet}

return to camp with the load upon his back. When he photographed his booty, hanging by the tent, I felt insignificant standing beside the great creature. And when, early next morning, the skin was removed, there seemed to be enough of it to make a good-sized blanket. 


\section{WILD-FOWL OF WILD-FOWL \\ (Ducks and Geese)}

Though the term wild-fowl is variously and loosely applied, there is no class of birds it better fits in its suggestive savor of wild, free Nature, than that called by naturalists the "Anatidæ." Whatever are or are not wild-fowl, Ducks and Geese are. There are few birds that reveal more their inherent wildness in retiring before the advances of human civilization. How often has my gaze wandered wistfully over the surface of some beautiful New England lake, searching for what was not there, some water-fowl floating upon the surface. There were the lilies, the woods, the surrounding hills, - all the elements of a beautiful landscape, save this alone,-and a sad lack it is. But in some of the newer states of the northwest it is very different. There man has been too busy in reclaiming and beautifying his own homespot to disturb the innocent home-life of his wildfowl neighbors.

None of my many bird-adventures have made deeper impression upon me than those of my first season spent in studying the breeding habits of the Ducks and Geese in the Dakota wilds. Though I had read wonderful tales of that region's bird-life, it proved to be one of those pleasant surprises, all too uncommon, where the actual equals expecta- 
WILD-FowL OF WILD-FowL

tion. Even from the car-window, on a branch railroad in North Dakota, as I neared my destination I saw the Ducks flying out from a series of shallow sloughs, alarmed at the approach of the tri-weekly train. It was the tenth of May, and there were scores of them just settling down to the annual task of nest-building. So near were they to the train that without the field-glass I could easily distinguish Mallards, Shovellers, Pintails and Blue-winged Teal.

Not many miles beyond this favored spot my friend and I disembarked, and soon were driving out from the little town along a level prairie road, bordered by dark fields, some of which were already delicately greened with the sprouting wheat. Close by the humble home of a settler, on the right, was a little pond covering less than an acre of ground, convenient for his cattle. And there were evidently his barnyard fowl, a flock of Ducks, enjoying their favorite element. But what did it mean? Just as we drove by, there was a sudden whistling of wings, and away they went, wild Ducks, - the same kinds we had seen from the train,-feeding within a few rods of the barn!

About six miles further on we approached the house where we were to stay over night. Here, too, a pond was prominent, right by the turn of the driveway, and it, likewise, had its Ducks, twenty or more of them. A Willet standing on the shore uttered his customary note of alarm, and they were off; but by the time we looked back from the house, there they were again, having circled back and alit. From the parlor-window I could see them so clearly with the glass as to be able to iden- 
tify every one, and note each motion. Some were paddling about, others were pluming themselves on the shore, but they all kept in pairs, as they did also when they flew. Among them was one pair of Green-winged Teal, a species that is very scarce in Dakota in the breeding season.

The next morning I was out at the break of day, even before it was light enough to see the birds. I soon found a series of small sloughs which were just full of Ducks. Each slough that I approached gave forth a score or so of searchers for breakfast and the early worm. That unfortunate creature this morning must have felt sluggish and indisposed, for it had been cold enough during the night to skim the sloughs over with ice near the shores. The muddy flats had also an icy crust, and my first exploit while trying to wade one was to trip on this crust and pitch headlong. To save myself, I naturally put out my arms, and in up to the shoulders they went in the cold, wet ooze! The Ducks quacked loudly, as if mocking, and I fear I should have lost my temper, but for so many interesting things that made wet clothes and a mudplaster trifles not worthy of interrupting the pleasant chain of thought.

A walk of about a mile from here brought us to a larger and more open lake. Large flocks of Ducks of various kinds were resting upon its surface, and a pair of Great Marbled Godwits were feeding on the prairie near the margin. A very tall bird stood on the shore, with long neck extended, taking note of our approach. We thought it was a Sand-hill Crane, but, when it swam out into the lake, we perceived 


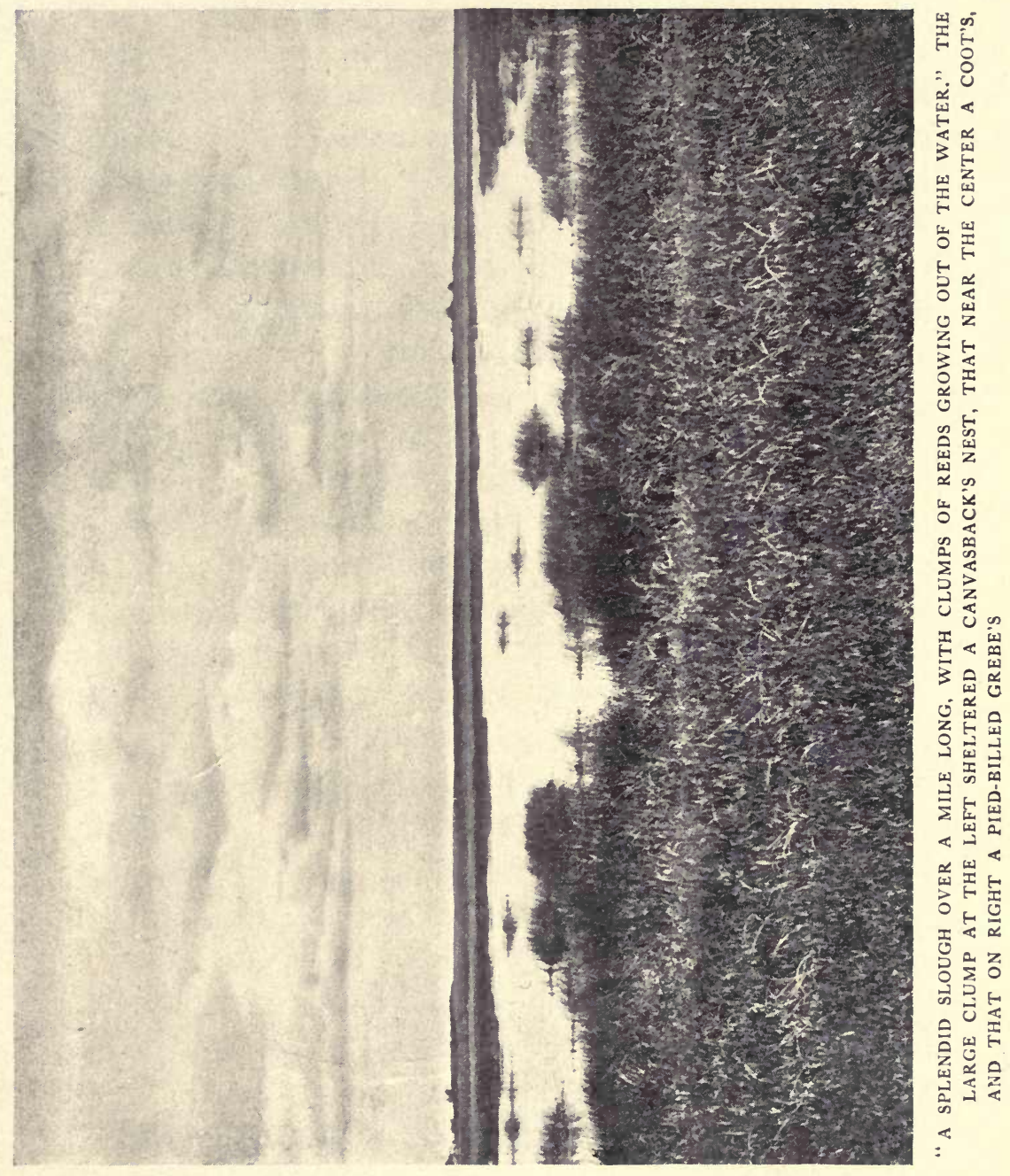


that it was a Canada Goose. We learned from a neighboring settler that Geese usually bred in the vicinity, so we began the exploration of an adjacent large tract of rushes, back from the shore, hoping to discover the nest of this bird. The search at length brought me out to the shore again, near a projecting point of land. As I came around the rather steep shore of the point, what was my amazement to come right upon a flock of Geese sitting on the beach, not twenty paces off. Eighteen of them were the common wild Canada Goose; the uther four were beautiful creatures, snow-white all over, save for the black outer half of the wingsSnow Geese-one of the last of the migratory flocks that had been pouring through the state on their way to the far north. It is hard to tell which felt the more surprise, the Geese or the intruder. For an instant they stood as though paralyzed, then sprang into the air and flew off with loud honkings. The Snow Geese went by themselves out over the lake and the others made a circle or two till they had mounted quite high, and then, in their usual wedge-shaped order, steered their course for the north.

Just a week later, with the same companion, I started out on a six-weeks' camping tour. Two fine horses drew a stout open double buggy, on the back part of which was loaded a tent and a complete camp outfit. We drove forty miles north and west that first day, and at night, as it began to rain, instead of pitching the tent, we secured permission to sleep in the hay-loft of a two-story frame barn belonging to a Norwegian family-the only barn, save 
shacks, that we had seen in many miles. There we made ourselves comfortable, getting supper with our little oil stove and then turning in for rest. It must be confessed that our sleep was none of the soundest. Down below were cows and calves, horses and colts, pigs and sheep, dogs and poultry, and noises of various kinds were incessant. Around us rats were perambulating, and a cat was making successful sallies from time to time, while a shrillvoiced cockerel on the beam above us had evidently decided that sleep was not to be allowed.

All night the rain poured down on the roof like an avalanche, and in the morning continued unabated. There was nothing to do but make another day of it - a rather dreary prospect. My disappointment, however, was tempered by the fact that the evening before we had passed a small slough, only five minutes' walk from the barn, that seemed to be full of Ducks. So, after breakfast, I donned boots and mackintosh, and set out for it with one of the Norwegian boys, who told me that last year a pair of wild Geese had raised a brood on top of a Muskrat house in this slough, and that he thought they were there again. As we approached a whole cloud of Ducks flew up, and I noticed many interesting Waders along the margin. The first thing was to look for the Goose nest. I waded out, up to my boot-tops, to the several "houses," but there was no sign of it. Then we took a turn along the shore, passing through a tract of reeds up from the edge. Suddenly, without warning, a female Pintail fluttered out almost from under our feet and rapidly disappeared in the blinding rain. In a little hollow, shel- 
tered by the reeds, she had built her nest of reedstems and grass, lined profusely with down plucked from her breast, and laid nine fresh eggs of a yellowish olive hue - my first Dakota Duck's eggs!

I had already noticed a fine male Canvasback swimming among some clumps of reeds, well out in the water. I decided to wade there, letting the boy beat along the shore. The Canvasback had disappeared, but when I got out not far from where I had seen him, I heard a sudden splashing and beating of wings, and the same instant saw a large Duck, that I recognized as a female Canvasback,

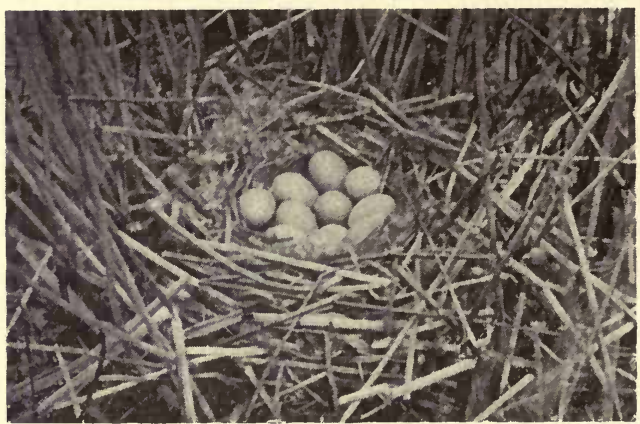

" I WAS SOON THERE, AND FOUND IN A LITTLE CLUMP OF REEDS A SORT OF SEMI-FLOATING 'ARK OF BULRUSHES,' LINED WITH . , . WHITISH DOWN." NEST OF THE CANVASBACK fluttering over the water ten or fifteen yards ahead of me. I was soon there, and found in a little clump of reeds a sort of sem i - floating "ark of bulrushes," lined with an abundance of whitish down, and ten large eggs of a sort of dark leaden color, a hue produced by no bird but a Canvasback. This mother had begun her work earlier than her Pintail neighbor, for her eggs seemed considerably incubated.

The weather cleared during the night, and the next day, with a bracing northwest wind, we drove thirty miles further to a fine large lake, and, pitch- 
ing our camp in a grove of timber on the shore, for several days found many interesting things to investigate. A few miles back from the lake was a rushy, grass-grown slough that supported a marvellous variety of Ducks. It was a mile and a half long, and, as we put up the horses in a sod barn near the shore, and saw some Gadwalls, Baldpates, Blue-winged Teals, Shovellers, Mallards, and Pintails feeding near-by, down where the cows drank, I realized what a wonderful place it was. The water was too deep to wade, except at the lower end of the slough, and the only boat had been burned in a prairie fire. For all that, I saw enough birds. Pairs of Ruddy Ducks were swimming among the reeds, holding their tails erect, as is their unique fashion. By this habit they can be distinguished from any of the other Ducks. The male, at this season, is very striking in his bright reddish coat and pale-blue bill. Eared, Horned and Pied-billed Grebes, and Coots, were everywhere near neighbors of the Ruddies. Farther out there were the Greater and Lesser Scaups, in pairs, also very many pairs of Redheads, and, most conspicuous of all, Canvasback couples that were floating about in the more open lanes and areas of wăter. In one place where I stood I counted eleven pairs of Canvasbacks, and one solitary male, whose mate had doubtless already begun her monthlong vigil somewhere in one of the reedy clumps. A pair of Pintails were busy on the prairie, near the margin, and I found they were scratching a hollow that was to be their nest. Wherever I went pairs or parties of all these species of Ducks that 
I have mentioned kept flying up, or were out in the water within sight. Thus there were eleven species of wild Ducks in that one locality, and all of them in good numbers. This is a Dakota duckslough at its best.

After a quiet Sunday in camp, our party being increased to four by a local guide and a visiting ornithologist, we made a trip to the "Enchanted Isles," described in preceding pages. It was the $23 \mathrm{~d}$ of May, beautiful, calm, and bright. We carted a boat on a buckboard, and visited each of the four islands, finding plenty of eggs of Cormorants and Ring-bills and a few scattering nests of Pintails, Gadwalls and Mallards - most of the Ducks having not yet nested. But there were some discoveries that I must describe in detail. We had been but a short time on the Cormorant Island

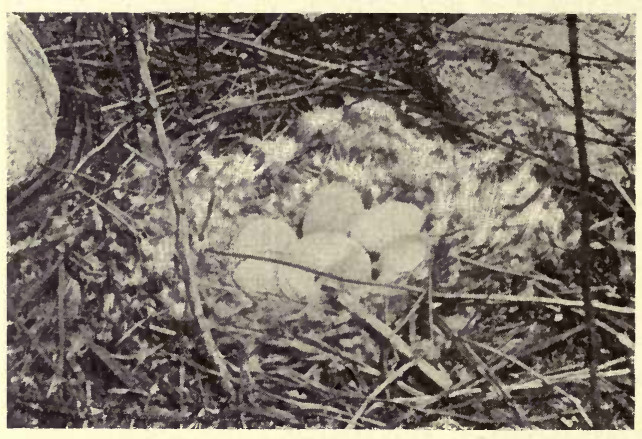

"PULLIiNG ASIDE THE DOWN, WE FOUND DISCLOSED TO VIEW SIX ENORMOUS CHALKY-WHITE EGGS" NEST OF THE (WILD) CANADA GOOSE when the guide called out to me. It was but a few steps to where he stood, by a clump of tall dry weeds. In the midst of them was a great bed of stems and grass, lined with an abundance of white down, that seemed to fill the nest. But there was something else white! Pulling aside the down we found disclosed to view six enormous chalkywhite eggs, each as big as two or three Duck's 


\section{WILD-Fow OF WILD-FowL}

eggs. It was a nest of the Canada Goose. We had heard Geese honking as we approaced the island, and had seen at least one making off. Here was the buried treasure they had hoped would be unobserved. I had always thought of the wild Geese as breeding only in the far north. This was the first nest of this sort that I had ever seen, and it would be hard to describe the feelings with which I viewed it. It seemed as though I were in a trackless wilderness, perhaps very near the pole, except that the sun was too warm for such high latitude. At any rate, I had the delightful sense of boreal adventure without its hardships.

We saw nothing of the owners of the nest, so, after photographing it, we proceeded to the second island, where we actually found another Goose nest in a short time. This one held five eggs and was situated in short grass - a sort of lawn it was - just back from the bank, on the higher part of the island, overlooking the lake. It seemed a rather conspicuous place for the great bird to sit with so little cover, but no doubt she squatted close enough when danger was near, if, indeed, she allowed anyone to approach within observing distance while she was there. This nest was very slight, being little more than a hollow lined with down.

There was no Goose nest on the third island, but we discovered another on the last that had evidently been rifled. It was a rude pile of grass and down, placed near one end of the island, at the top of a gravel-spit, among some weeds. Out at the extremity of the spit, as we approached, we saw the two Geese standing with outstretched 
necks. Great birds they were, and too wary to be approached.

From here we drove northwest, away up to the international boundary, exploring some large lakes eastward from the Turtle Mountain region. On the 3oth of May we reached Rock Lake and pitched the tent on the prairie close to the stony shore. By this time more of the Ducks had laid. I was particularly fortunate there in finding Blue-winged Teals' nests. The morning after our arrival I was rowing on the lake, and happened to land on a sort of peninsula formed on one side by a marshy bayou. The land was broken and rolling, but near the shore it was flat, almost marshy, and covered with very profuse dry grass of the previous year's growth that had escaped the prairie fires. My companion almost trod on a Western Meadow Lark that left her arched nest in the grass and six eggs for our inspection. Just after this I was returning to the boat, when-spring, flutter-away went a Blue-winged Teal from the long grass at my very feet. It took me but a second to reach the spot, and, parting the grass, I gazed into my. first Teal's nest, with its ten small, creamy eggs, well spattered with excrement, which the bird dropped as she flew. I afterwards found that this last is the usual occurrence when a Duck is surprised and flushed from her eggs. This nest was well down in the thick dry grass, and would have been practically impossible to discover without flushing the bird.' It was built in a hollow in the ground, of dry grass, with which the abundant dark gray down that lined it was more or less mixed.

After a few minutes we started on again, and 


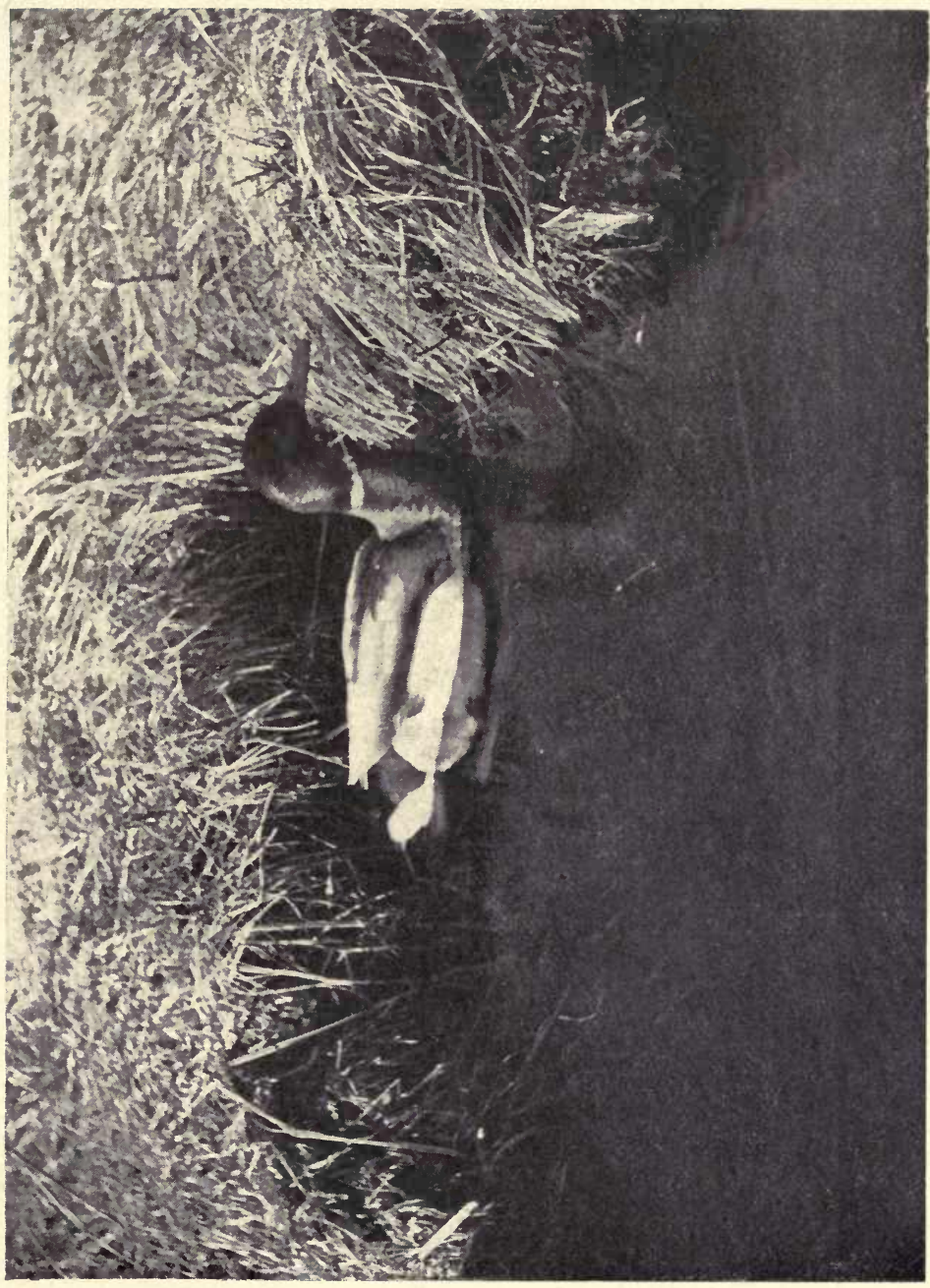

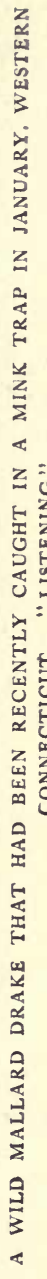


had gone but a few steps when another Teal flushed at close quarters, and I soon found the nest, similar to the last, with a set of nine eggs. In the same way we found three more Teals' nest in this tract,

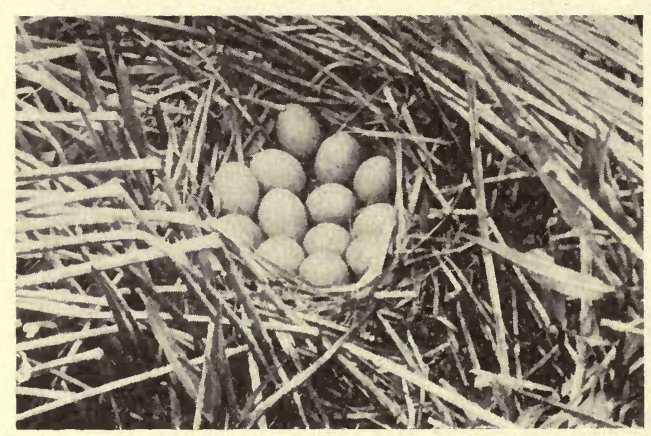

"THIS FIRST DAY OF JUNE I ALSO FOUND MY FIRST MALLARDS' NESTS" five in all.

The first day of June $I$ also found my first Mallards' nests. One was on a little hummock, in a tussock of grass, a little way out in the water where the

lake shore was marshy, the big bird springing forth with a bound into the air when I was perhaps fifteen yards away. The nest was quite substantial and well lined, and held ten yellowish drab eggs, slightly tinged with green. The other nest was on an island in front of our camp, placed in a thicket of trees and bushes. The first time the Duck flushed I could hardly get a glimpse of her, so I came again later in the day, and, approaching carefully, easily identified the nine eggs, that, like the others, were quite fresh.

A few days later we drove on, still eastward, over a most desolate, mainly uninhabited prairie, to Rush Lake, which I have already described. On one part of its shore a fire had burned over a large tract of grass and rushes, and I saw quite a number of nests of scorched Ducks' eggs exposed to view. I shall remember this great prairie lake 


\section{WILD-Fowl OF WILD-FowI}

as the place where I found two Ducks' nests new to me. After going over the burnt tract I pulled up the tops of my boots and waded along the shore, some rods out, among clumps of long grass. Away went a brownish Duck, with grey wings, from a tussock a little beyond me,-a Redhead, I saw at once. There was a very large basket-nest of dry rushes, lined with down, and a no less sizeable assortment of eggs, fifteen of them I finally counted. Each egg, too, was large, nearly white, with a faint greenish

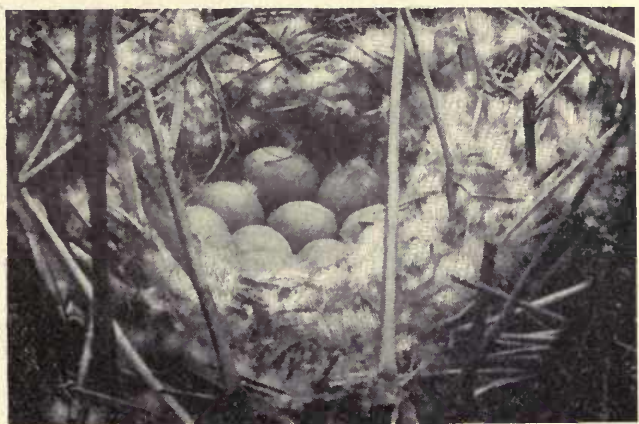

NEST OF REDHEAD

tinge and a shell so smooth and hard as to remind one of a billiard ball. Altogether it was a large and interesting discovery.

At this point I waded ashore and had no sooner set foot on dry land than a Blue-winged Teal flushed from the prairie grass, and I found her eight fresh eggs in a nest of grass and down similar to those already found. From this spot I had gone but a short distance, when out went another Teal, and directly I was inspecting eight eggs more. Having by this time rested a little, I again tried wading, and very soon had the pleasure of seeing a female Shoveler unwillingly flutter out from some very thick grass near me. I had been told that this species usually nested on the dry prairie, 


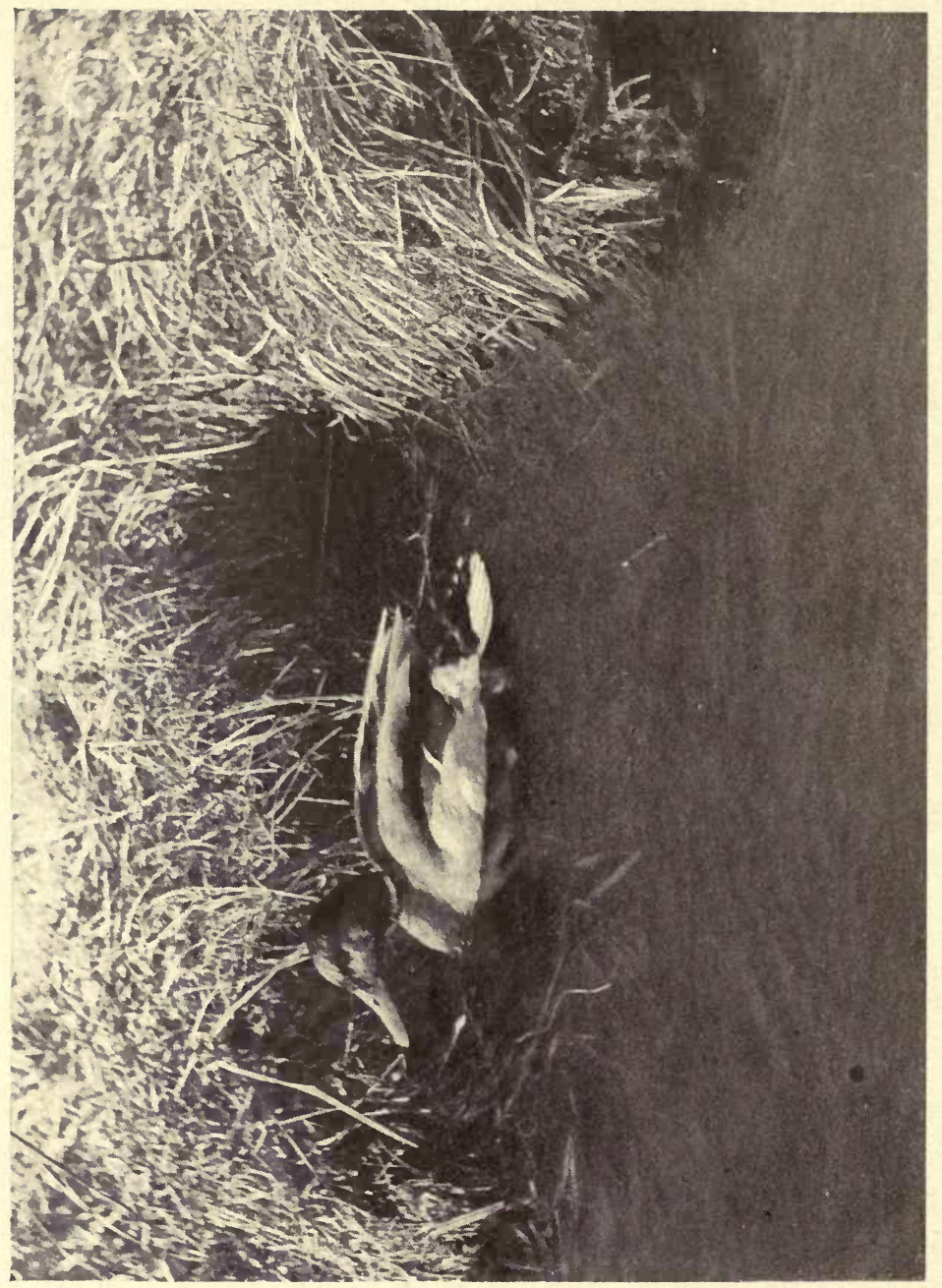

0 
WiLd-Fowl OF WILd-FowL

but here was evidently a nest out over the water. For some time I pawed over that grass in vain, and began to think I was mistaken, when a piece of down climging to a blade of grass caught my eye. Under it was the nest, at the very bottom of the high tussock. The grass met over it without showing any opening whatever. I should never have found it without flushing the bird. There were ten fresh eggs, yellowish white, the color of the Teals', but larger.

Many interesting happenings followed, until in time we reached the Turtle Mountain timbered country, which, though interesting, did not afford much in the line of Ducks. About all I saw there were a few Blue-winged Teals, Redheads, Goldeneyes and Mallards. With the latter I had a rather amusing experience. One day I found myself on the shore of a lake in an uninhabited region, miles from camp at dinner-time, and no food with me. At one o'clock I was beginning to feel rather faint, when a Mallard flushed from the grass just up from the water, leaving six perfectly fresh eggs, evidently an incomplete set. It occurred to me that this was my dinner, providentially furnished. As it was raining, cooking was out of the question, so I emptied two of the eggs into my mouth, with as little tasting as possible. For an hour at their place of destination there was a condition of unstable equilibrium. Strong will at length conquered, but the appetite for raw Ducks' eggs was effectually destroyed.

To redeem the memory of Turtle Mountain Ducks' nests, however, occurred a much pleasanter 
episode. I had been arduously wading a very boggy area of rushes, a sort of bayou back from a lake. Nothing especial had come to light, and I was struggling absent-mindedly on, when I almost trod on a bird upon its nest in some thick rushes. It fluttered out in the terrified, pitiful manner of the Ducks, literally right from under my feet, a brownish Duck of medium size, with pearl-grey specula, or wing-bars. Without going very far, it alit in some open water, where I approached it within a few feet, behind some rushes, and confirmed my first impression that it was a female Ring-necked Scaup, distinguished from the other female Scaups by its wing-bars being pearl-grey instead of white. After thus satisfying myself I went back to where I had thrown my handkerchief by the nest. There was a pretty canopy of rushes arching over the neatly built basket, soft with down from the maternal breast, in which lay twelve dark brown eggs almost the color of Bitterns'. It was the only nest of the Ring-necked Scaup found during the whole trip.

Owing to the illness of my companion we soon had to leave the "mountains" and stay in a neighboring town for a few days. With a boy for company, I explored the region. One hot day, June 18, we drove twenty miles to Long Lake,-a great alkaline flat, it was, covered with a uniform depth of only two or three feet of water, with great areas of grass and scattered clumps of rushes. I had been told that Canvasbacks nested here, and after an arduous search, finding several Ducks' nests where the broods had been hatched, a female Can- 
vasback started from her canopied nest in a clump of rushes, just as I had caught a glimpse of the bulky mass of stems and down. I realize how inadequate is the power of words to convey the full impression of such a scene and the interest and excitement of such a moment. Though I have seen it enacted hundreds of times, I would willingly tramp miles to experience that thrill once more. For one thing, at such a time the mind is in a state of expectancy through the effort of the search. The wildness of those prairie lakes adds to its charm. Every clump of thick vegetation suggests limitless depths of possibility, and success comes frequently enough not to allow hope and expectancy to flag. And when it does come "it is so sudden," that rustling of the grass, the beating of wings, the sight at close quarters of the noble bird rising from the mysterious fastness. Every nerve is strained to note each marking and detail in that brief, fleeting instant, into which a whole day of life is crowded. It takes training of eye and mind to so utilize that golden speck of time that there shall not afterward be the regret of a confused mind and an unidentified nest. Then comes the delicious expectancy of the approach to the clump, the peering in, the first sight of the hidden treasure. The whole scene is one of Nature, inanimate and living, at her best. In this spirit, with enthusiasm aglow, I watched the swift Canvasback until she disappeared behind some rushes, and then peered into the bed of down. Nine dark eggs there were, and two strangers, the smooth white eggs of a Redhead that had laid in the wrong nest. Neither the hot 
marsh, the heated, und rinkable alkaline water which imparted no relief in cooling brow or moistening parched tongue, nor the long dark prairie drive, protracted beyond the midnight hour, dispelled that enthusiasm.

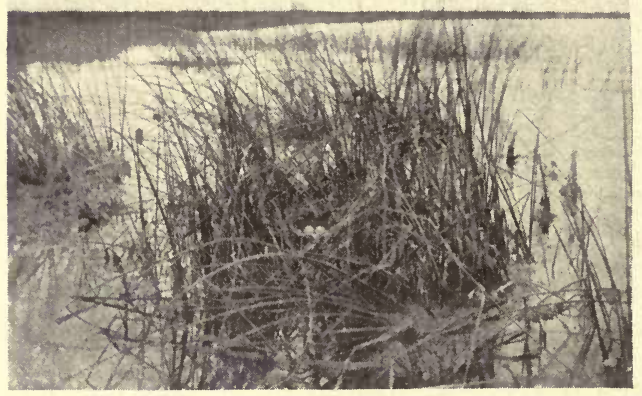

"THEN COMES THE DELICIOUS EXPECTANCY OF THE APPROACH TO THE CLUMP, THE PEERING IN, THE FIRST SIGHT OF THE HIDDEN TREASURE." NEST AND SURROUNDINGS OF THE CANVASBACK

Just out from the town was a little slough of a few acres, with the usual border and clumps of rushes, where Ducks and other birds resorted. One morning, as I reached the outer edge of an area of flags, I heard sounds of pattering and chirping. In a moment a brood of eight little downy Ducks, evidently but a day or two out of the shell, appeared in the open water in a well-ordered line, swimming with all their might. And then, with a rush of despair, came the mother, a Green-winged Teal, to the rescue. She threw herself in the water in front of me and lay there fluttering, as though sorely wounded, swimming a little and then flying up, only to return in a moment to repeat the same performance. Meanwhile the little ones had disappeared in the rushes further along, but the little mother desisted not in her protestations till I withdrew from the water's edge to inspect some young Pintails, nearly half grown, that were skulking in the grass. We caught one, and my boy-companion 


\section{WILD-FOWL OF WILD-FoWL}

was for taking it home. But, in pity for it under the neglect I was sure it would receive, I pushed it out from under his arm, and it escaped to the water.

It is time now, in the narrative, that we hasten back to the region of Devil's Lake, and describe another visit to "The Enchanted Isles." It was on June 27 , late enough in the season for the tardiest Ducks to have about finished laying their full sets, another beautiful day, when we again landed on what we have called the third island. A cloud of Terns and Ring-bills hovered over it. Hardly had we stepped from the boat when up went a Pintail from the weeds, leaving her six incubated eggs for us to admire. Half a dozen steps more, and away fluttered a Baldpate from her eight fresh creamy-white eggs; then another of the same species, a few feet further on, from a set of ten. Each nest was placed under a clump of weeds among the loose rocks. Then, as I retraced my steps towards the boat, a Lesser Scaup flew from the grass a few rods ahead of me. After a little search, I found her set of nine beautiful brown eggs.

Meanwhile my companion was investigating a clump of rose-bushes near by, on the summit of the island. Seeing under them some rubbish with down clinging to it, he poked a stick into it and pulled it apart, unearthing seven great flesh-colored eggs of the White-winged Scoter, a bird that had only recently been suspected of breeding in the 
United States. Numerous individuals had been hanging around these islands all the spring, and I knew they must be breeding somewhere about. This nest was little more than a hollow in the damp earth, with a rim of straw, stems, and sticks, lined with a small amount of dark gray down. The eggs were fresh and cold, the set incomplete. The bird had scraped loam over the nest, and it seemed like digging potatoes to get at the eggs and prepare the nest to photograph. This set me to hunting for more Scoters' nests, and it was but a moment or so before I dug from under a small clump of brush close by a similar nest with only one buried egg, the Scoter having but just begun to lay.

Then a Gadwall got up from her set of ten white eggs, and, as we proceeded, at every few steps Gadwalls, Scaups, and Baldpates started from their nests. So incessant was the fluttering up of Ducks from beneath our feet that my mind became utterly confused, so far as taking exact account of the various nests was concerned.

The matter of identifying nests had its difficulties. Although subsequent. investigation has cleared away most of the uncertainties, I find myself obliged to confess that it is practically impossible, under many circumstances, in the hurry of a Duck's departure when flushed from a nest, to distinguish positively, for instance, between the female Gadwall and Baldpate. The latter seems to have rather more white on the wing-bar, and is of a slightly lighter gray plumage, - that is about all. The eggs of both are white, and although sets of the Baldpate are usually the more creamy, I am not cer- 


\section{WILD-FowL OF WILD-FoWL}

tain that the difference always holds. The female Pintail at a distance looks very much like both of the above, though she has a longer, more slender neck. But her eggs are distinct, liaving an olivaceous caste. The eggs of the three Scaups, Greater, Lesser, and Ring-necked,-are alike in color, a decided brown, and different from eggs of any other Ducks, but are easily confused one with the other, as are the birds themselves. The eggs of the Blue- and Green-winged Teal are indistinguishable, but one can identify the birds at close range. The female Mallard can be told by its large size, spotted plumage, and blue speculum. Females of Redhead and Canvas-back are somewhat alike, but the latter is larger and lighter in color, and the eggs of each I consider distinctive. The Shoveler and her eggs can usually be distinguished,- though there is some resemblance to the Pintail,-as the size is considerably less. As to Ruddy Duck and White-winged Scoter there can be no mistake. The eggs of the former are astonishingly large for the size of the bird, have a rough, pitted shell, entirely unique, and are pure white. Scoters' eggs are larger than those of any Duck nesting in the United States, save the Eider, which is not found breeding in the interior.

Leaving this island, at length, with its many nests of Terns and Ducks, we crossed to island number two, only a short distance away. Large numbers of young Ring-bills were scurrying about among the rocks or swimming out into the lake. It was the same as on the other islands with the Ducks. We scoured through its many areas and 
clumps of grass, weeds, or bushes, and found enough eggs of Gadwalls, Baldpates, Scaups, Scoters, Pintails, and Shovelers to have filled many

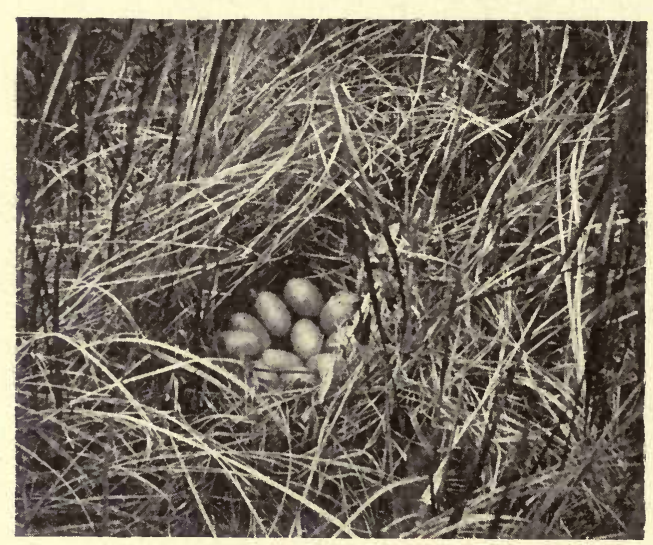

" AND FOUND ENOUGH EgGS . . TO HAVE FILLED MANY PAILS, HAD WE GATHERED THEM." NEST OF LESSER SCAUP

pails, had we gathered them.

It was not surprising, with this teeming bird-life, to find that the Ducks not infrequently laid in e a ch others' nests. I found a mixed set of ten Shovelers' eggs and four of a Scaup, flushing the female Shoveler from this aggregation. I also found Shovelers' eggs in a Baldpates' nest.

On the summit of the island, under clumps of rose-bushes, Scoters seemed to hold sway. Under one clump we literally unearthed ten buried eggs. My companion looked into another near-by thicket, and a great Scoter sprang almost into his face, revealing a magnificent set of fourteen large eggs. At the western end of the island, on the highest ground, was a very large clump of rose-bushes, as high as one's head, the others having been but a couple of feet in height. Near the top of one of these bushes was the nest of a common Kingbird with three eggs. I crawled into this maze of briars and was about to leave when I thought I 


\section{WILD-FOWL OF WILD-FowL}

saw some dark down projecting from the ground. In a moment I had dug out six more Scoters' eggs. There was almost no nest, the eggs being laid simply in a hollow, lined with a little down, and over them the bird had scratched the earth. The eggs are thus left till the set is completed, when incubation begins. Just as I got out again into the open I saw my companion, as he bent over a nother clum p, neariy knocked down as a Scoter suddenly flew almost into his $\mathrm{face}$. Here was another typical nest with ten fresh eggs. Under still another clump was a hol-

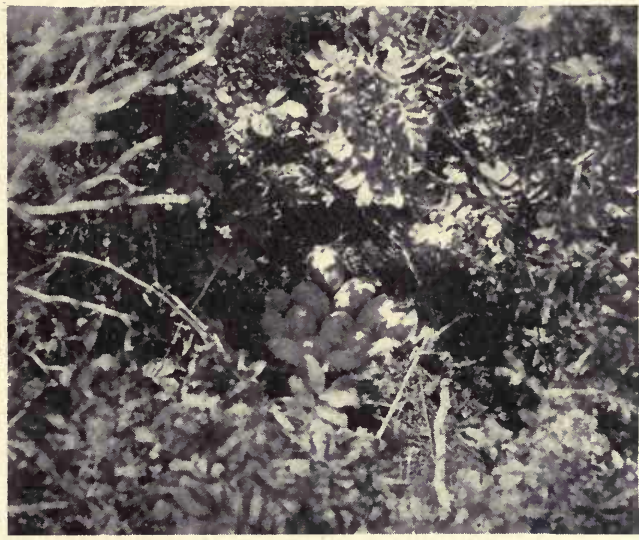

"A great scoter sprang almost into his face. REVEALING A MAGNIFICENT SET OF FOURTEEN LARGE EGGS." NEST OF WHITE-WINGED SCOTER, UNTIL RECENTLY HARDLY KNOWN TO SCIENCE

low freshly scratched out, evidently by a Scoter, in preparation for her first egg. It is now known that the Scoter breeds very late, seldom finishing laying before July, and often well along in that month.

A hurried trip to island number one revealed, besides sixty Cormorants' nests still with eggs, a few more nests of Ducks. Then we made for the fourth and last island. I paid but passing heed to the Baldpates, Gadwalls and Scaups that flew from their nests, or to a Pintail whose eight eggs were on the point of hatching. I wanted to 
see more of the little-known nesting-habits of the Scoters. As they seemed to select clumps of bushes, I felt, as I neared the only clump on this island, that there must be a Scoters' nest under its shade. Nor was I disappointed, as I cautiously parted the bushes and looked in. There, about a yard from me, sat a female Scoter on her nest, the picture of consternation, as our glances met. My first thought was to get the camera and photograph her on the nest, so I cautiously withdrew. But the bird by this time recovered her presence of mind. The bushes parted and she waddled out past me, almost brushing against me, then taking to wing, at length to drop into the lake and dive. The nest contained thirteen fresh eggs. Probably, as with most other Ducks on these islands and elsewhere, from eight to eleven is the ordinary number of eggs in the full complements. On another visit to these islands a friend of mine actually caught a Scoter on her nest and obliged her to sit for her picture ere he restored her to freedom.

The next day I made a visit to the slough where, over a month before, I had seen so many kinds of Ducks. We had first to dig out a boat on the large lake, that a gale had nearly filled with gravel, ere we couli take it along with us on the buckboard. The rushes and grass had grown very high, and it was not as easy as before to see the Ducks, though there were plenty of them. Here, at last, I found my first nest of the Ruddy Duck. It was a genuine floating structure, built out in the middle of the slough in deep water, with only a few stems of grass 


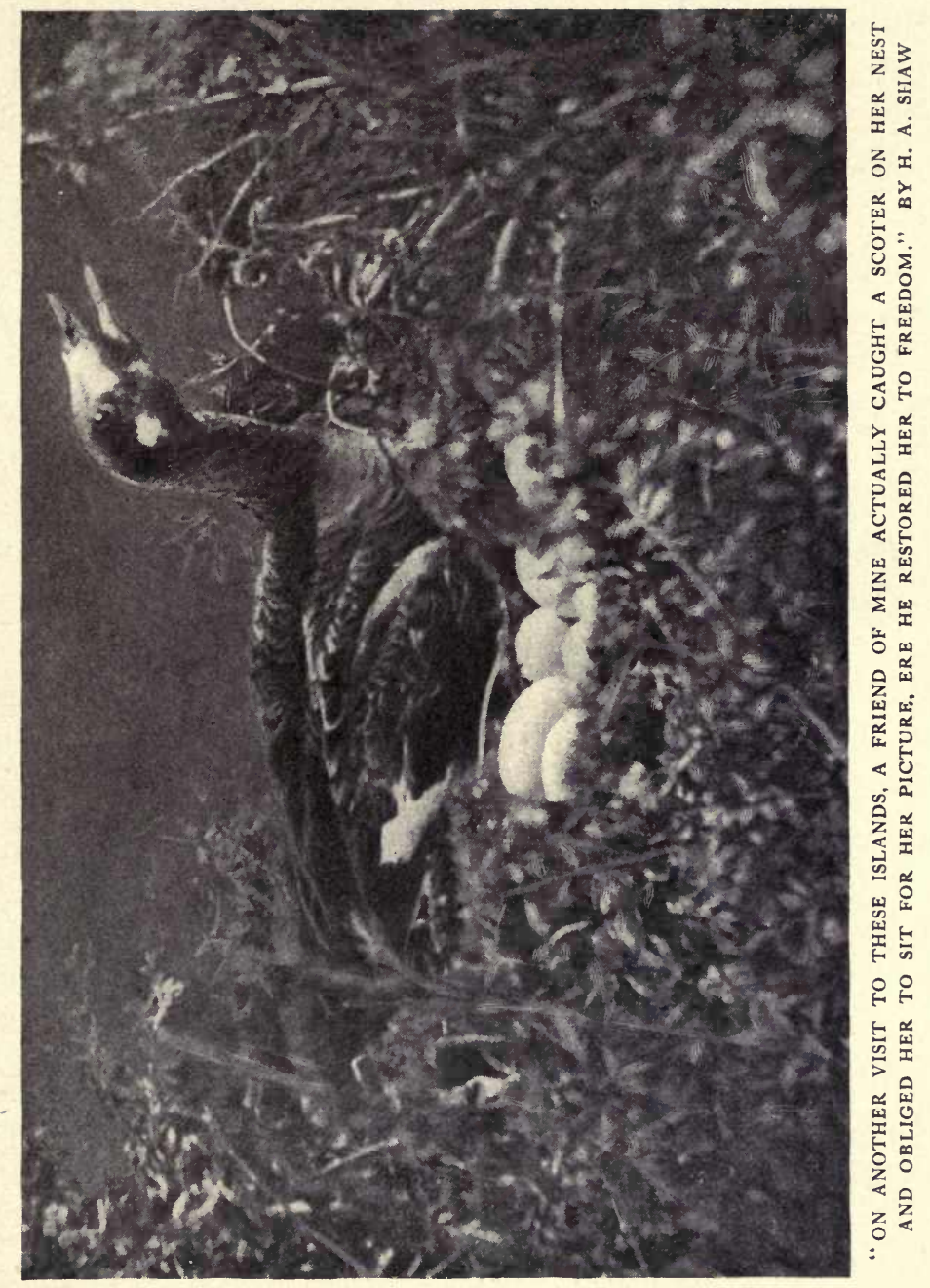


near it for anchorage and shade. In location only was it like a Grebe's nest, being dry, deep and bulky, though with little down. A recent storm, probably, had partly upset it, and several of the fifteen large white eggs were lying on the edge or spilled out into the water. It seemed almost impossible that such a little bird as a Ruddy Duck should have laid that pile of eggs, several times its own weight, in less than three weeks. When I first saw a Ruddy's eggs I could hardly believe they were properly identified, as they are larger than the eggs of the Mallard or the Canvasback.

Canvasback, Redhead, and Ruddy Ducks can be classed together in the nesting season. They all build elaborate nests in the rushes out over deep water, and when one is found in a slough the other members of the triumvirate are also likely to occur. As though in proof of this, I saw, as I inspected this nest, a female Canvasback, followed by eight young, swimming across the lane of water. Not far away, as later I waded from the boat into the rushes, I came upon a fine nest of the Redhead, canopied over with the dry rushes, with thirteen Redhead eggs and two of the Ruddy Duck, and then, still another, in some long grass growing out of deep water, very bulky and downy, with eleven Redhead eggs and one of the Ruddy.

But it is not only amid grass and rushes that the nests of Ducks are found, though many people suppose this to be the case. To such a sight that I witnessed would be a revelation. It was "Memorial 
Day," and three of us were exploring a patch of timber near the shore of a Dakota lake. Seeing a knot-hols in an oak tree, about fifteen feet from the ground, with a piece of white down clinging to its edge, I called to my friend to come and inspect it, as a probable nest of the American Golden - e ye Duck. No sooner were we all under the tree than we saw, through a lower

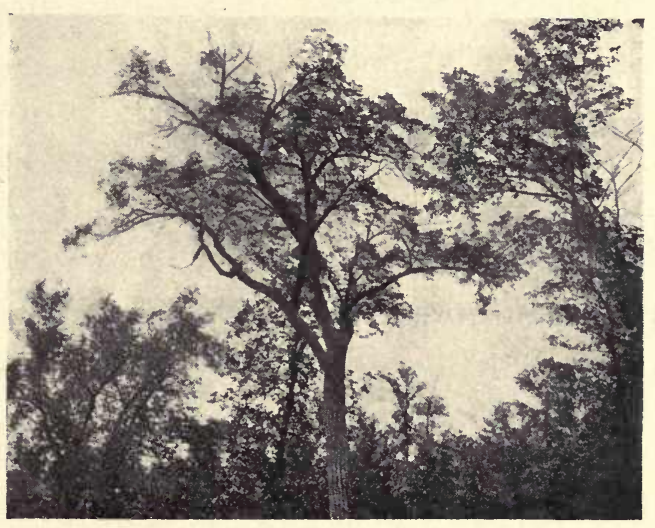

"BUT IT IS NOT ONLY AMID GRASS AND RUSHES THAT THE NESTS OF DUCKS ARE FOUND." NEST OF AMERICAN GOLDEN-EYE IN THE KNOT-HOLE, CONTAINING SEVEN EGGS

crack, a movement within. Directly a brown head appeared at the entrance, and the Golden-eye proceeded to come forth. But she had a hard time of it. The hole was so small that a slender human arm could hardly be inserted. The poor Duck had to wriggle and twist back and forth like a snake, I should think for ten seconds, ere she was able to emerge and take to wing. It was a singular and interesting sight. Then I climbed the tree and found that about two feet below the hole, in a bed of soft, snowy down, there were ten large fresh eggs of a greenish color. The cavity was so small that they had to be piled in two layers. It must have been the scarcity of suitable holes that compelled the Duck to submit to such discomfort. 
On a certain part of the shore of Devil's Lake there is another similar area of timber, where, late in June, during the tour described above, I had a most fascinating time for several days with the Golden-eyes. We had just encamped near-by, and I was taking a preliminary stroll through the grove that had some quite large trees, some of them being mere decayed shells. At length I came to a stub with a large round opening at the top of the main trunk, about ten feet from the ground. No bird flew at my rapping, nor was there any down visible at the entrance. However, I though I would scramble up and look in. About an arm's length from the opening was a mass of white down and feathers that filled the cavity. Reaching into it, I felt eggs-

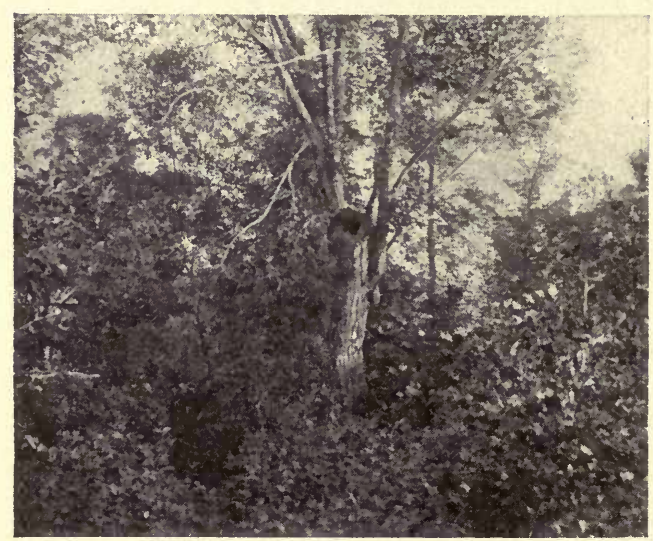

“ AT Length i CAME TO A stub With a LARge Round OPENING AT THE TOP OF THE MAIN TRUNK." NEST OF AMERICAN GOLDEN-EYE CONTAINING SIXTEEN EGGS

a large number of them. It $\mathrm{see} \mathrm{med}$ as though the count would never end, but I finally ascertained that the number was sixteen, piled there in a great hea $\mathrm{p}, \mathrm{two}$ or three deep.

With this encouragement I began to look for more holes. Only a few rods from this stub I soon discovered another hole in a large tree, about as high up as my head. Below it, about waist high, 
was an opening that someone had made with an axe to get at a Duck's nest. There was down around this lower hole, and through it I easily put my hand on a set of seven eggs. Very near this tree was the most likely opening of all, a great hollow almost large enough for a man to crawl in, about twenty feet up a leaning oak. No down was visible, but I felt certain that there must be a nest, and my expectations were more than realized. As I scrambled up, and my head was just opposite the hole, whirring, thundering sounds issued from within, and out went a female Golden-eye, with a frightened murmur, almost in my face. I could have seized her had I wished to. Peering in, I counted eleven eggs at the bottom, in the usual "feather bed." I could just reach them, and the first one that I took out to examine I found was pipped, the duckling chirping within.

The next day was very rainy, but it cleared in the afternoon, and again I climbed the tree. I never expect to see a prettier sight. The mother lay at the bottom, surrounded by a beautiful flock of black and white young. Some of them were on the old Duck's back; others were under her, apparently, and several of them were moving around in the limited chamber, picking at the chips on the bottom. Instantly the old bird caught sight of me. Turning over partly on her side, she looked up with a frightened expression, and hissed like a snake. It was a most delectable little family scene. After I had enjoyed it for a few moments I withdrew from the hole and began rapping the tree. It took a number of calls before the mother reluc- 
tantly responded, and flew out, as before. Every egg had hatched, and the little creatures were active and well dried off, ready for their exit to the great lake and the wide world. I hoped to see-them taken from the nest, but the next morning it was rainy again, and, when I got there later in the day, they had departed. Where the tree is over the water, the young have been seen to leap out themselves; but other observers report that the old bird usually carries them out one by one in her bill.

As hollow trees-or any others for that matterare not very plentiful in Dakota, and there are a good many families of the American Golden-eye and Hooded Merganser, like Abraham and Lot of old the two kinds have wisely decided to separate. The Golden-eyes seem to monopolize the hollow trees by the lakes, the Mergansers those by rivers The fact is that they prefer still and running water respectively. In one trip that I made down the Sheyenne River after the middle of June, I found the pretty hooded fowl with the saw-like bills quite abundant on the stream; but a hollow, with greenish white egg-shells, from which the brood had hatched and gone, indicated that we were too late for eggs that season. The male Hooded Merganser is a very striking bird, with his fine crest and conspicuous black and white plumage. I shall not forget how a pair of them on this river looked, as they floated near together on its quiet surface. In summer the stream is but a few yards wide, so when I crawled up through the bushes to the edge of the bank just opposite the Ducks, I was very near, indeed. They did not see me, and not until after 
WILD-FOWL OF WILD-FOWL

some time spent in paddling about and dressing their feathers did they fly off.

In my visit the past season to the lakes and sloughs of this splendid prairie region, I renewed my acquaintance with the Ducks and Geese, and made some further observations. As it happened, we found several nests of the Canada Goose, this time in marshy sloughs, large platforms of stems built in areas of broken-down rushes that made a foundation above the surrounding water. It was June, and we were too late, for only an addled egg or two remained. The Geese lay usually early in May, or even in April, it is said.

The Ducks seemed to be about as numerous as before. On the islands they held their own well, though not so many Scoters were nesting there. But the presence of large flocks of them in different bays showed that great numbers of them were breeding in places along the shores, doubtless, from others' observation, up on the adjoining prairie. I noticed more mixed Ducks' sets than ever. We found here nests of Gadwall, Baldpate and Scaup that had each one or two Scoters' eggs in them, and these first three also intermingled with one another. A Ring-necked Scaup had a nest with ten eggs. On June 22 I came upon a sight that I had never witnessed before. A Shoveler flushed at our feet from the grass, and there were ten young in the nest, all dry, and ready to take to the water, which they tried to do as soon as their mother left them. One of the party put his hat over them 
while I set up the camera and snapped at them the instant the hat was removed. As soon as we allowed them to they all streamed out of the nest, and down the

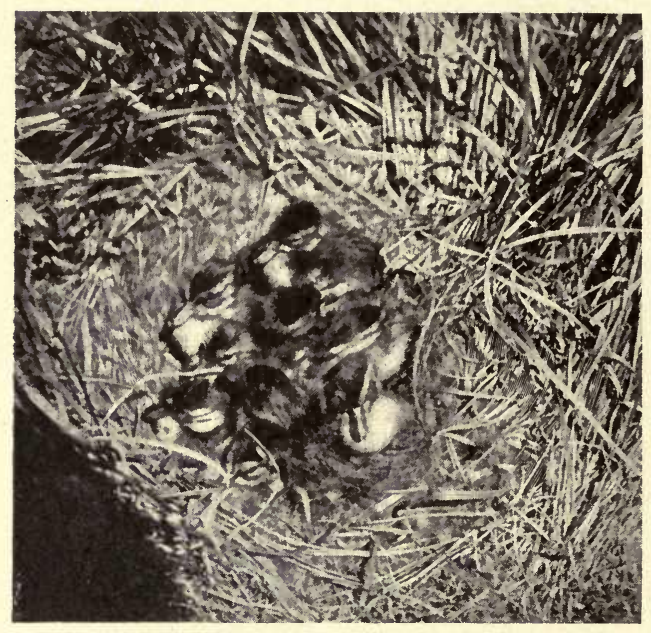

“A SHOVELER FLUSHED AT OUR FEET FROM THE GRASS, AND THERE WERE TEN YOUNG IN THE NEST" bank into the water, to join their distressed mother, who was flapping about near the shore calling to them in a plaintive manner. In one patch of low rosebushes there were three Ducks' nests withın less than ten feet - a Scoter's with twelve eggs, a Gadwall's with eleven, and a Scaup's with ten - quite an aggregation, those thirty-three eggs!

During a week's time that we spent among the sloughs first mentioned in this chapter, from June 7 to I4, we found a considerable number of nests of the Canvasback, Redhead, and Ruddy Ducks, built out in the reeds over water averaging kneedeep, all of which made a very interesting study. The Ruddy Ducks were only just laying, and had anywhere. from one to ten eggs. These nests, unlike the one previously mentioned, were well hidden away in the reeds, usually in the midst of a large clump or tract in the very thickest of the vegeta- 
tion, and canopied by the surrounding reeds being drawn over them, and even twisted together. In fact, some looked almost exactly like a larger type of Rail's nests. As has been the experience of others, we never could catch Mrs. Ruddy on the nest. She always skulks off, and allows not even a glimpse of herself.

The other two kinds usually remain sitting on their eggs, flushing sooner, however, than the prairienesting Ducks, when the intruder comes within ten to fifteen paces. The Redhead is a great layer. Some days I found half a dozen nests, most of which had as many as ten eggs, several times fifteen, and once I flushed a Redhe ad from

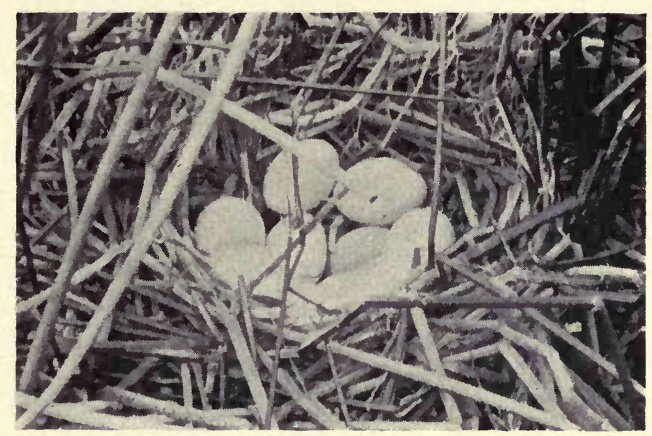

“ THE RUDDY DUCKS WERE ONLY JUST LAYING, AND HAD ANYWHERE FROM ONE TO TEN EGGS . . WELL HIDDEN AWAY IN THE REEDS"

twenty-two eggs - the largest set that I have ever seen in the nest of any bird. The Canvasback usually had ten or eleven eggs, sometimes as few as seven. One nest that I found was in a very large, open clump, away out in the water. I saw it first when the bird flew at some distance from me. There were six eggs, and I visited it a few days later to see if she had laid more. Mrs. Canvasback was asleep on the nest, with her bill resting on her breast. I stood within ten yards and watched her for several minutes. Think of it! the famous Canvasback of 
the epicure at home in the northern wilds, out on the lake, asleep in her ark-what a scene it was! But for lack of

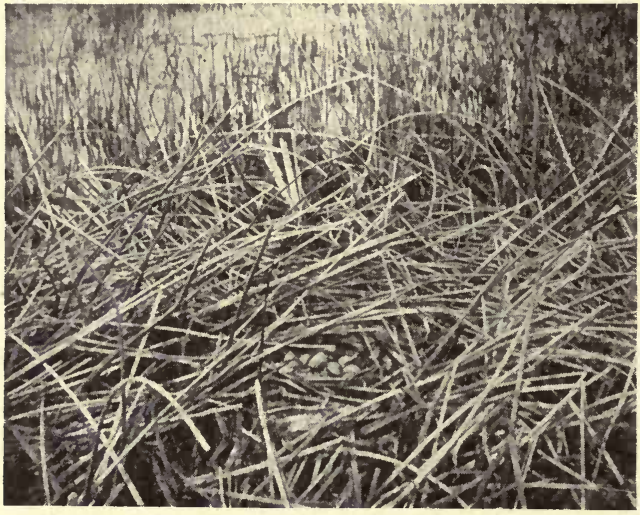

"THE REDHEAD IS A GREAT LAYER" time I might have managed to photograph her some day by accustoming her to the sight of the camera. At length she raised her head, and saw me. For an instant $\mathrm{sh} \mathrm{e}$ see med paralyzed, then she stood up and, with a quick spring, went flying off, just over the tops of the reeds. The same six

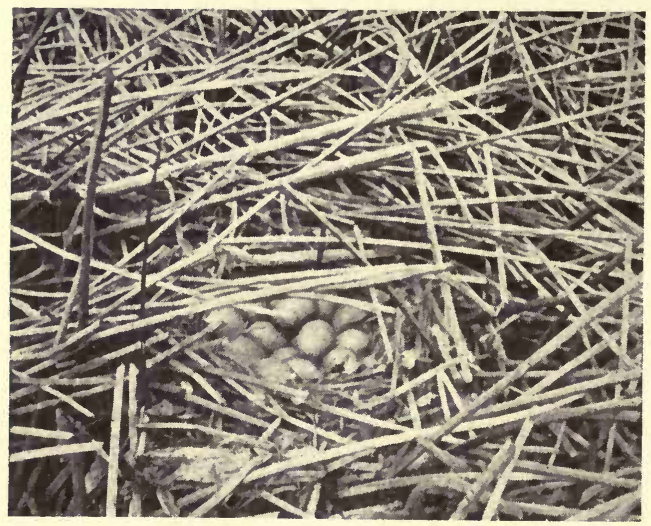

THE SAME NEST OF REDHEAD, SHOWING SURROUNDINGS

eggs were there, heavily incubated I found when I examined them more closely. And I saw another thing I had overlooked before: only two of the eggs were her own, the other four being Redhead eggs. Not over a gunshot from this spot, in a clump of reeds away out in the lake, a quarter of a mile from shore, another Canvasback 
had a nest with seven eggs of her own and one of a Ruddy Duck. No further away was another Canvasback with eleven eggs that were about to hatch. For a wonder, these eggs were all hers. Though I imagine that this tribe are all busybodies, I consider the odd little Ruddy as the greatest adept at poking her blue nose into other duckpeople's busi-

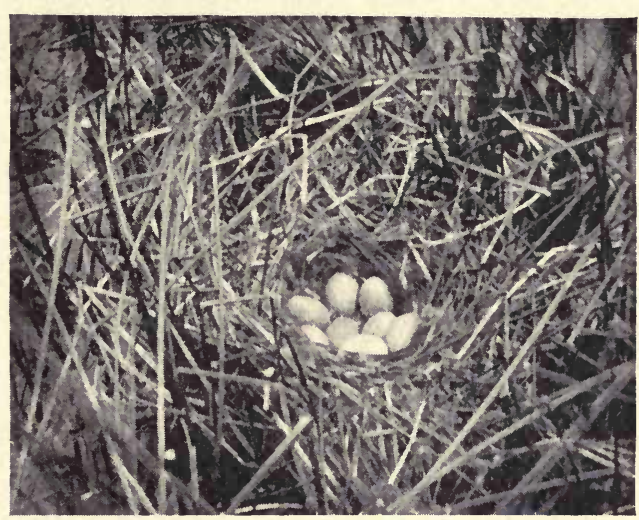

“another canvasback had a nest with seven EGGS OF HER OWN AND ONE OF A RUDDY DUंCK"

ness. I saw a Canvasback on June Io swimming in this slough with five young. Whether the blood of any of these was "Ruddy" I could not tell, though probably the eggs were laid early enough to outwit that semi-parasite.

The breeding dates of these various Ducks varies considerably with the earliness or tardiness of the particular season. On my first trip I found the season very backward. Many of the Ducks had not finished laying by the first of June-the majority not even then. But last spring they were very much earlier, as the season opened warm and pleasant, and the various species arrived at an early date. While there is no exact time at which each species laysfor individuals are very erratic-there is an average date at which one can expect to find the bulk of a species thus employed. The little calendar that I 
give I would not set up against the observation of others; it is simply the average of two seasons' continuous observation. Mallards and Pintails are notably the early birds, laying any time after the first of May-occasionally before, I am told-though I think that about May 20 one will find the greater number of nests. By about this time, in ordinary seasons, the Canvasbacks have laid and the Hooded Mergansers. May 25 is about the right date for Golden-eyes; June I for Teal, Shovelers, and Redheads; June Io or later for Gadwalls and Ruddies; June 15 and on for the Scaups and Baldpates, and the ist of July for White-winged Scoter.

To make the acquaintance in the nesting season of certain other Ducks which do not go to the remote north, we shall have to explore the Atlantic coast region. It is by no means as easy to find them there as on the Great Plains, yet patient searching will now and then be rewarded. Most of the sea Ducks, such as the Scoters and Oldsquaws, migrate to Labrador or beyond. Some day I hope to follow them, but as yet my wanderings have not been extended north of the Magdalen Islands. Yet there are some interesting Ducks even there to be studied.

Away out by East Point is what is called "the Great Pond," a shallow body of water certainly a couple of miles long, occasionally inundated by the sea, that breaks across the beach in storms. At its east end are what the fishermen have named the "Egg Nubbles," a number of tiny islets, on which 


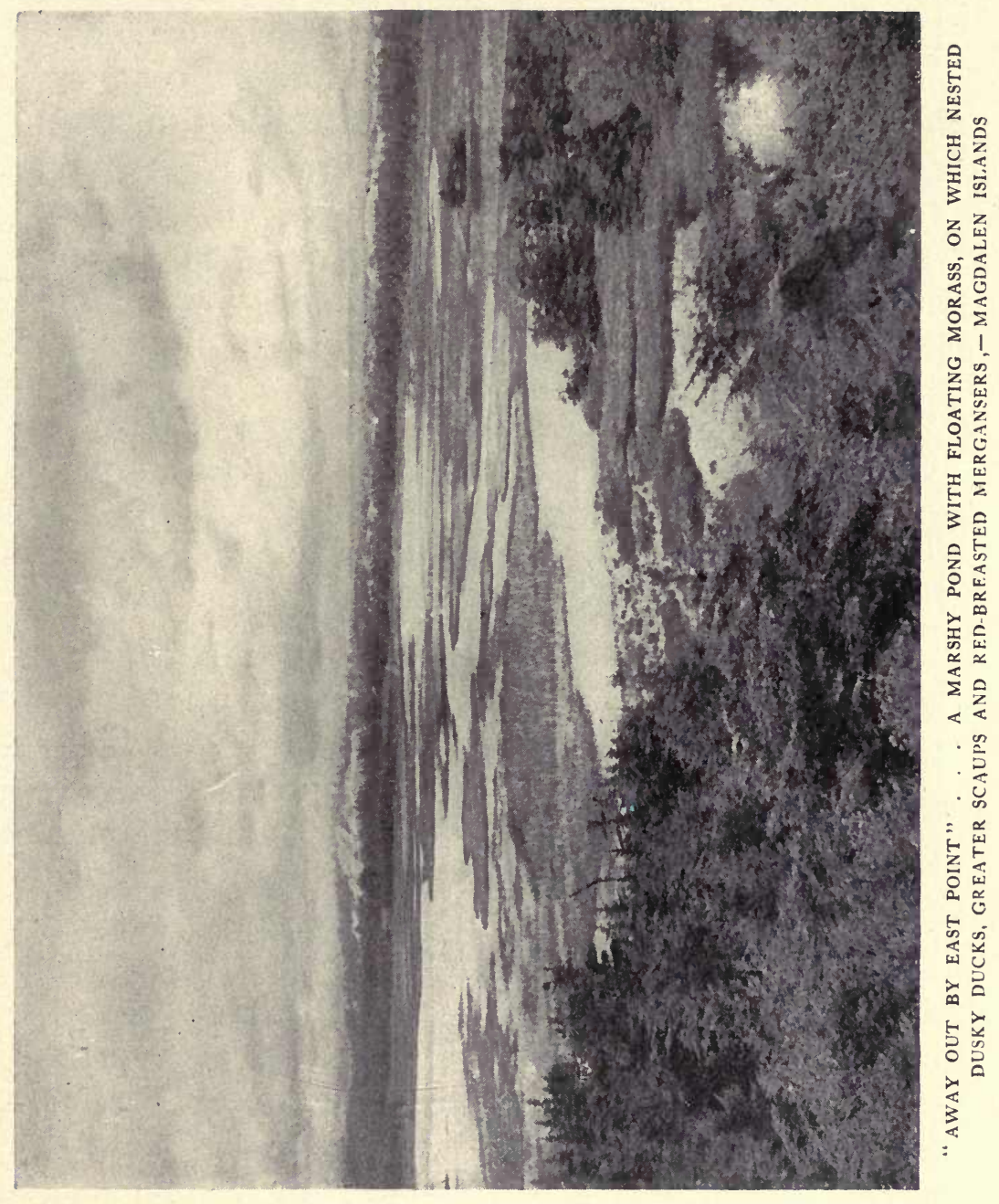


Terns and Ducks breed. At our first arrival we visited them, and were disappointed not to find any Ducks' nests, although there were scores of Ducks of several kinds, mostly Red-breasted Mergansers, feeding or flying about. We made the trip again on the 29 th of June. An easterly storm was raging, and we droves even or eight miles over beach, dunes, and barrens, in an old cart drawn by an ancient white horse. Even in the thickest of winter clothing and overcoats we were shivering. Reaching our destination, we tied the horse to a clump of stunted spruces and waded out to the "Nubbles."

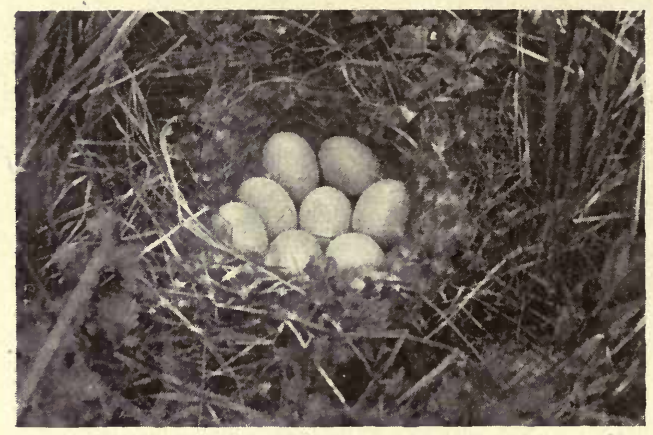

“ A DUSKY DUCK FLUSHED FROM THE GRASS UP FROM THE EDGE, LEAVING A PRETTY DOWNY NEST WITH EIGHT FRESH EGGS"

We had almost reached the first when a Dusky or "Black" Duck flushed from the grass up from the edge, leaving a pretty, downy nest with eight fresh eggs that closely resembled the eggs of the Mallard. I was surprised to find fresh eggs of this Duck so late, as, from our first arrival, we had seen broods of young in the ponds, some of them several weeks old. A few feet away, under a little bush, a Merganser had scratched out a hollow, as yet unlined, and had laid the first egg of her litter.

Then we waded across to the next islet, and here found what I had hoped for. The fishermen all said that "Bluebills," or Scaups, nested on these and 
other islands. I had seen some of the birds and was prepared for what now took place. Up fluttered a thick-set brown Duck, with white wing-bars, from the grass a couple of yards up from the shore. It was unmistakably a Scaup, and a large specimen at that. In a typical,well-concealed, downlined nest were nine large, dark brown eggs. Their size, measuring from two and a half to two

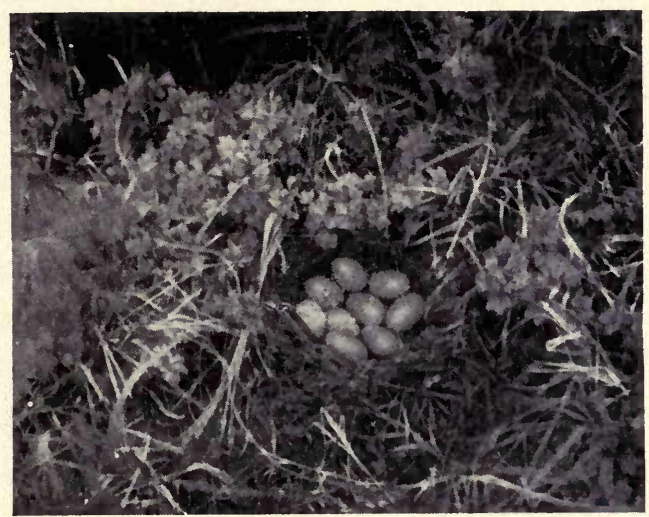

"IN A TYPICAL, WELL-CONCEALED, DOWN-LINED NEST WERE NINE LARGE DARK BROWN EGGS." NEST OF GREATER SCAUP, MAGDALEN ISLANDS. "ACCORDING TO THE BQOKS, NONE OF THE SCAUPS HAD BEEN KNOWN TO BREED IN EASTERN NORTH AMERICA "

and six-tenths inches in length, made it sure that they belonged to the Greater Scaup. According to the books, none of the Scaups had been known to nest on the Atlantic coast.

The fisherman affirmed that Teal of both kinds nested on the islands. For a time it seemed that all my arduous wading and tramping would fail to verify this. But on the afternoon of June I6, as I was wearily dragging my heavy boots along the edge of a slough, something suddenly went flapping over the grass, out from under a projecting spruce-bough that sprawled flat on the ground, on which I had almost trodden. It was a female Bluewinged Teal. I lifted the bough, and there were 
twelve eggs, about to hatch. After photographing them I replaced the bough, and when I passed the spot again two days later, scattered egg-shells told of another brood added to the Duck-farm of the Magdalen Islands.

We had poor success in finding "Shell-ducks' " nests - as the Mergansers are here locally called. A boy found an incomplete set under a spruce tree in the woods, and a dog broke up a couple of similarly placed nests on a densely spruce-grown island, but all I found was that one egg (mentioned above). Most of the females were still with their mates out on the ponds, and evidently, this year at any rate, incubation did not begin till July. Some of them nest in the grass by the shores, but their general practice is, I was told, to lay under the dense low spruces, often well into the tangled woods, in almost impenetrable thickets. Hence their nests

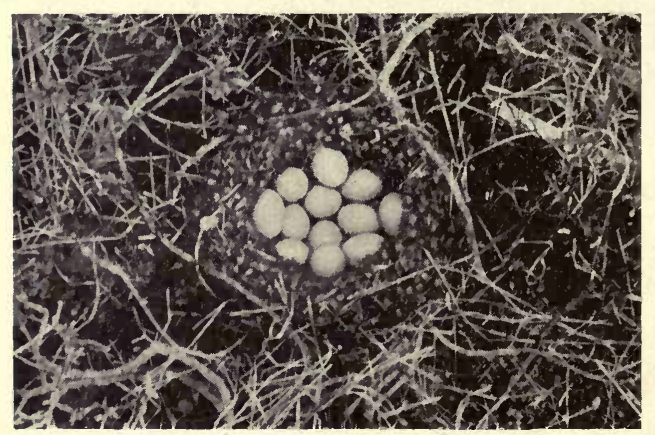

"I LIFTED THE BOUGH, AND THERE WERE TWELVE EGGS, ABOUT TO HATCH." NEST OF BLUE-WINGED TEAL, MAGDALEN ISLANDS are very hard to find, even when the birds are incubating. They are very abundant on these islands. The eggs are of a drab color, a little lighter than those of the Scaups, and quite shiny. Their relatives, the Goosander and the Hooded Merganser, as well as the American Golden-eye, are said to breed in the eastern Provinces and in Maine, all 


\section{WILD-FowL OF WILD-FowL}

of them resorting to tree-hollows by the retired lakes. The Red-head is also reported as nesting rarely in this region.

It is quite surprising that while incalculable thousands of the Eiders-known to fishermen and gunners as "Sea Ducks" - pass up the St. Lawrence on their way to Labrador and beyond, without even stopping at the Magdalen Islands, quite a few of them remain for the summer on various lonely islands along the coast of Maine, New Brunswick, and southern Nova Scotia. Owing to persecution, they are usually very cunning in concealing the whereabouts of the nests. They always cover them with a profusion of the soft "eider-down." when they have occasion to leave. If a boat appears, they will even skulk from the weedy clumps or sheltering bush, slip down to the water's edge and swim off under water. I remember once, as we rowed around a point of "No Man's Land," coming right upon a female Eider that had probably just left her nest somewhere up on the shore. At first she did not try to dive, and she was so near that I leaned over the side of the boat to lay hold of her. Imminent danger brought her suddenly to herself, and the speedy plunge that followed was the last I ever saw of her.

Once I caught the cunning Eider napping. It was on Green Island, off Mt. Desert. I was following a sort of grass-grown ledge, quite high up from the water, when I almost trod on a female Eider, sitting close. Her sudden start gave a decided, though pleasant, shock to my nerves. I found a bed of eider-down,- - just as soft as it is reputed to 
be,-and in it three greenish olive eggs, - the largest laid by any of the Ducks, nearly as large as Goose eggs,-were very cosily bedded.

When we come as far south as southern New England, all we can hope to find of breeding Ducks are the Dusky and the Wood Ducks, and it is no easy matter to find even these. Usually it is more by accident than otherwise. On Martha's Vineyard I was once exploring an alder swamp for the home of a pair of Marsh Hawks, when a great Dusky Duck suddenly whirred up from beneath an alder, almost in my face, and I found my first Duck's nest with an even dozen fine eggs. This was the second day of June, and they were almost ready

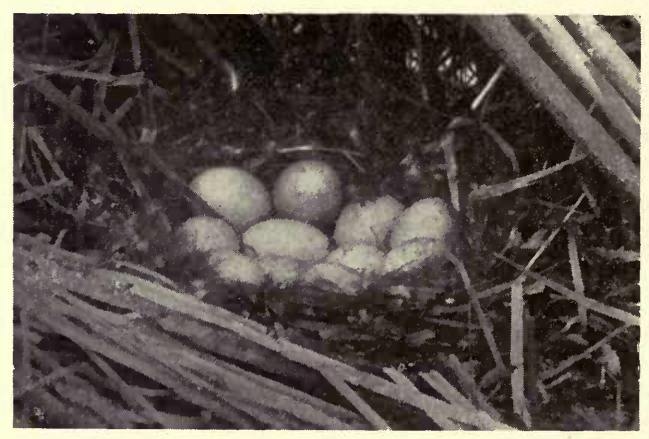

" ON PULling IT APART I FOUND ELEVEN WARM EGgS OF THE DUSKY DUCK." FOUND IN KENT, CONN.

to hatch. Another time when I was exploring the rushy edge of a pond in Connecticut, I noticed a dark place under some rushes that looked suspiciously like Duckdown. It was that, indeed, and on pulling it apart I found eleven warm eggs of the Dusky Duck.

The Wood Duck is the most domestic of all the tribe, and is very apt to nest in some most unexpected place, close to human habitations. I knew of one nest in a knot-hole of a large maple, only six feet from the ground, right on a well-traveled road 
near a house. Hearing of a Duck being seen about a certain farmer's barn, I climbed up on top of his hay-mow, - the middle of May, it was - and discovered a female Wood Duck sitting on ten eggs in a hollow she had dug in the hay and lined with down from her breast. She went in and out of a hole near the eaves. The farmer said that during her laying time she was absent all day, but at night she and her mate sat on the ridge-pole of the roof, and each morning when he entered the barn to milk she flew out, having deposited another egg since the evening before. Another equally interesting bird,-possibly the same one,-made a nest the next season in a barn two miles from this one, and the farmer caught her on the nest. The eggs are small and rather round, shiny, and of a beautiful rich cream-color. The Wood Duck finishes her laying, in southern New England, by the middle of May, the Dusky Duck usually by the last of April.

Altogether, I have found the nests and eggs of nineteen species of Ducks and seen the young of one other. A very interesting study it has been to me, and I look upon these opportunities as an inestimable privilege, which it was given not even to the great Audubon to enjoy. The breeding habits of most of these Ducks in his day were absolutely unknown, and even to the present little has appeared in books about them.

I have also enjoyed making a study of the Ducks that come in the migratory flight to Massa- 
chusetts. This has meant many a watching with hunters in the Duck-stands on various ponds, chasing the Ducks on the ocean, or waiting in a gunning-line for them to come to me.

It is very exciting to watch the approach of a flock to one of these "stands," or "bowers," on the shore of a pond. The flock first flies over and begins to circle around the pond. The live decoys set up their hoarse clamor of invitation. At length they splash down out in the middle of the pond near the "blocks" or wooden decoys. Looking cautiously about, they get their bearings, and begin to listen to the decoys. They do not always yield to the treachery, but when they once are deceived they swim in a body at a rapid rate right for the stand. Suddenly the guns, pointed through loopholes, blaze out at a concerted signal and there is meat for the hunters' table. A great many are thus taken in the ponds of southeastern Massachusetts and elsewhere. The best season is throughout October, especially about the middle, after a storm, when a cold northwest gale starts up. How they will fly, flock after flock, not only in early morning and late afternoon, as at ordinary times, but all day. Many kinds will be found represented in the number of the slain.

Late in October the stands make ready for the Canada Geese, some of them keeping large flocks of tame Geese, bred from wild stock, for decoys. Some of these decoys are wild birds that have been winged by shot. In a few days such cripples will become completely domesticated, and even eventually breed in captivity. November is the time for 
the "wild Goose chase," and until the ponds freeze up. If the migrating flocks are overtaken by thick or stormy weather and alight in the ponds, they are apt to fall easy prey. I have known of literally cartloads being taken off from these ponds after a night of this kind.

The staple, standard fowl for the hunter is the Dusky, or "Black" Duck, excellent for the table and one of the wariest of them all. Next to it in abundance, of the fresh-water Ducks, is the handsome Wood Duck. With these two, as residents, the hunting season begins, and they are about all the Ducks we have until with the early frosts the migrants begin to appear. Pintails, Mallards, and Redheads come as often as any of this migratory class. Sometimes when I have watched through a loophole in the "stand" a bunch of Mallards or Redheads out on the pond, the green or red heads of the males glistening in the sunlight, I have felt that the staid old New England pond was being born again. Such glories seemed foreign-unnatural to it. I wish it were possible that for five years, say, Duckshooting could absolutely cease, and the ponds be again populated as they once were. Baldpates come rather sparingly, usually single ones with other Ducks, while the Gadwall, Shoveler, and Canvasback are only rare stragglers now. I fear this may some day be the case with the little Ruddy Duck that comes-when it does come-in considerable flocks, and allows gunners to row up and exterminate them. I have often known cases in which, out of a large flock, not a single individual got out of the pond alive. 


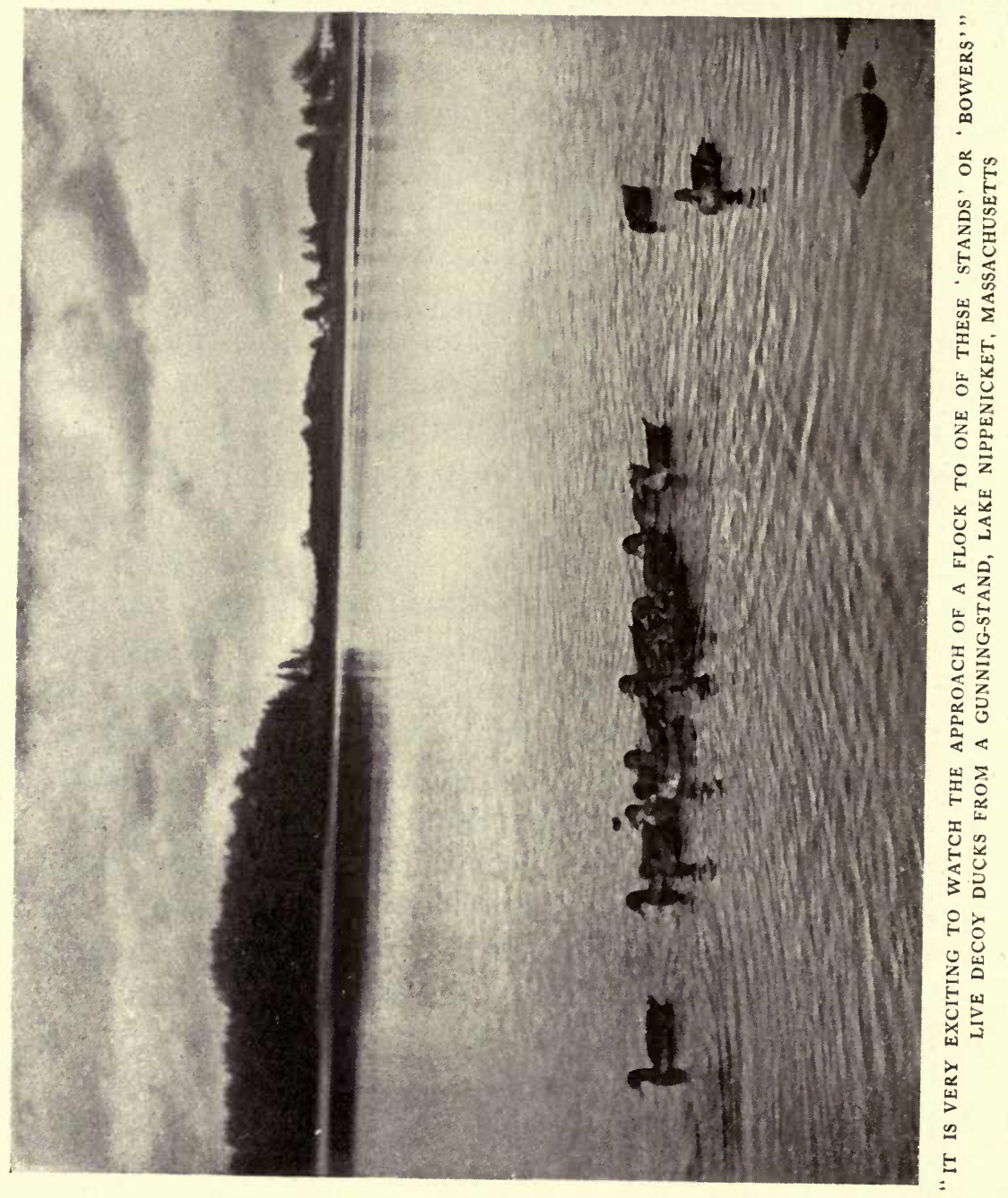


Though the Scaups are classed scientifically among the "Sea Ducks," they seem to me to be found almost as much on fresh water as on salt. A great many of the Greater and Lesser Scaup frequent the large ponds, and take good care of themselves, not minding the decoys nor allowing themselves to be approached. I have seen, and taken, the Ring-necked Scaup occasionally. The other Sea Ducks that come into the ponds, especially during the easterly storms, do not fare so well. I refer to the three Scoters and the Oldsquaw, or Long-tailed Duck. They seem bewildered, and will not usually leave, though it cost them their lives. The gunners soon see them, and paddle toward them down-wind. The foolish Ducks wait for a fusillade in the water, and then secure another, rising toward the boat. At length all are killed but stragglers, which are followed up and shot separately. Last fall, on October i I, I happened to be in Berkshire county, Massachusetts, near Lake Buell, and began to hear accounts of wonderful Duckshooting in the lake that day. Almost every family in the community had Ducks hanging up in the shed,- Surf and White-winged Scoters. There had been a storm the day before, and toward night an immense flock of these Scoters, probably lost and wearied, settled down into the lake. Many were killed that night and the next day. A hundred and fifty-eight was the number of "casualties" reported. Wild Geese are also addicted to similar wanderings and disasters, especially in sleet storms, during their flight. At such a time a flock of them, when I was a boy, descended into our gar- 
den, in the suburbs of Boston, and spent the night under the currant bushes! We did not know of it at the time, and our big dog kept some would-be pot-hunters at bay, so the Geese escaped.

With the three Mergansers, especially the Hooded and the Goosander, the little Buffle-head, the American Golden-eye, and the rare Barrows' Golden-eye, the list is possibly exhausted of the Ducks that come into the New England lakes and ponds. But the seacoast is full of interest and wonders in that direction. South of Maine the Harlequin Duck and the King Eider are so rare as to hardly enter into this account, though I have personally known of their capture on the Massachusetts coast. One of the fine coastwise sights is the spring flight of the Eiders. During the early days of April, a mile or two off the Chatham bars, I have seen long lines of them, coming all the time, pass by on their way north. Each flock is led by a male,-a striking creature with his white back, black under-parts, and greenish head. The brown females alternate with the males more or less irregularly, and the string of the large, swiftly moving fowl, fifty to a hundred or more in number, is an impressive sight. If the wind happens to come on strong from the southeast during this period, they often fly well in around Monomoy Point, and are shot from the beach by men concealed in pits. I have often seen the flocks, hungry on their travels, turn into Chatham bay and feed on the mussel-flats.

There, also, the Brant Geese resort in large 


\section{WILD-FowL OF WILD-FoWL}

numbers. I have watched flocks of them that extended in a solid mass for literally acres. They are exceedingly shy, and though such a flock will always rise a long distance away, the roar of the many wings comes to one as the sound of thunder. The flats about Monomoy Point are notable as the great Brant-shooting ground of New England, where the shy fowl are taken by means of shootingboxes sunk in the sandbars, which latter are often artificially made for this purpose. A big string of Brant at the depot or in the baggage-car is a familiar sight. The Brant are also taken in the fall flight in the various "cooting-lines" along the coast. I have seen hordes of them there pass by, but they almost invariably sheer off to sea, and go around the end of the line, much to the disappointment of the men in the boats. One day I certainly thought that the Brant were about to violate their safe custom. A fine bunch were flying low, and coming right for the boat next to mine. I fairly held my breath, as I expect did the two men in that boat. The Brant were within a hundred yards, and seemed doomed, when some one fired a shot at a passing Loon, and the Geese turned and went back. I saw one of the men take off his cap and hurl it down at the bottom of the boat in a rage.

Another of the prime wild-fowl sights of such bays as Chatham is the exit of the Oldsquaws at sundown. They feed during the winter days up at the head of the bay. To see or shoot them, one should anchor in a skiff in the middle of some narrow channel. At length there will come a confused chorus of weird cries, resembling the music 
of a pack of hounds on the trail, - and music indeed it is. Presently a line of fowl will appear, sweeping down the channel. They do not always seem to notice the boat, and I have often had them double right by the bow when I sat up to shoot. I think that there is no swifter flier among birds than this garrulous "Squaw," and if one is to hit such a mark very often, he must be an adept. Going at such tremendous velocity, when one is brought down, I have been amazed at the distance that its momentum will carry it, ricochetting over the water, before it can stop. They appear to rest on the open sea at night, where they are quite safe from molestation. On cold, still days they sit in flocks on the water and their chatter, which often seems to resolve itself into major thirds, is to me one of the finest sounds of Arctic-like nature at this season.

The Golden-eyes also feed in the bays, and, hidden in a seaweed "blind," one can toll them up with wooden decoys, and have good sport. As spring approaches, the Sheldrakes, or Mergansers, especially the Reb-dreasted, become more numerous, - the males now splendid with their greencrested head-dress,- - and come readily to the decoys. The little Buffle-head-Teal-like-skims over the bays and dodges the hunter by swimming under ice-fields, coming up beyond. I learned this lesson once when I had a flock cornered in such a way that I thought they could not escape when they undertook to dive. I waited and waited, and presently saw them away off in another lane of water.

When the bays are frozen over all but a narrow channel, the fishermen turn from fish to fowling, 
and, clad in white, build ice-stands along the edge of the channel, and shoot large numbers of the unwitting fowl that follow the lane of water.

The coastwise spring migration becomes apparent during the last half of March, reaches its height in the first half of April, and is practically over early in May, the procession ending with large loitering flocks of the Scoters, late breeders as they appear to be. In the return flight of autumn flocks of male Scoters will put in an appearance as early as the latter part of August. Then in September some of the young appear, but there are no great numbers till October, and not till nearly November, or until the frosts become severe, do some of the hardier sea Ducks and the Geese arrive. There are considerable differences in their manner of migration. Most of them, it is true, follow the coast line, but individual flocks keep just out of gunshot from the shore, while others fly miles from land. The direction of the wind has much to do with this. With a strong wind blowing on shore, most of them fly close in, while on calm days they are apt to be far out. Moreover, some species, as the Scoters, Oldsquaws and Eiders, ordinarily fly low over the water, though they often will rise if they suspect danger, while the Mergansers, Scaups, Golden-eyes or "Whistlers," and most of the others, are apt to fly high.

Conditions of wind have also much effect upon the number of fowl to be seen in migration, even in the height of the season. Some days almost no birds are seen, while on others thousands are passing. The strengthening east wind preceding a storm is a great time for a flight. An east wind is 
nearly always good, though it is apt to make the sea rough for boats. The gunners at Cape Sable, Nova Scotia, think that the first day of a southerly wind is one of the best times. Low temperature also helps to keep the fowl on the move. The worst weather for a flight is a pleasant, warm day, calm or with an off-shore wind. The time of the day is also a factor. The first two or three hours after dawn are the best. Often fowl fly well all the morning, but usually by noon, or at the latest the middle of the afternoon, the flight is about over, though occasional flocks may be seen till dusk.

Under the head of the Scoters, or "Coots," as the gunners call them, come three different sorts. The Surf Scoter is the commonest: The handsome black male, with white on the head, is popularly called the "Skunk-head Coot," as though it were a different species from its mate and young, which are known as the common "Gray Coot." Next in abundance is the "White-winged Coot," distinguishable by its larger size and white bar on each wing. The main plumage of the male is black, while the females and young are of a duller, more rusty hue. Last, yet fairly common, is the American or Black Scoter, nicknamed "Butter-bill Coot," on account of the conspicuous patch of yellow skin at the base of the bill, about the color of a lump of butter. It is only the male that has this and is thus named, its whole plumage being deep black. The female and young are confused with those of the Surf Scoter under the name of "Gray Coot." The best way to tell them apart-which very few gunners can do-is by the bill, the plumage being a good 


\section{WILD-FoWL OF WILD-FoWL}

deal alike. The Surf Scoter, whatever the age or sex, has a large, swollen sort of bill, whereas the bill of the other species is more like that of the Dusky or "Black" Duck.

Besides the Scoters, the Oldsquaws and Redbreasted Mergansers, or Sheldrakes, are the other two most common species encountered in this lineshooting, though various other Ducks are sometimes obtained. The other kinds, except the Eiders, are more accustomed to fly high, and will not mind decoys on the open sea. The Golden-eyes and Scaups, or "Blue-bills," are usually rather common. They ordinarily fly high and keep away from the boats. The Mergansers, too, like high flights, but often break this rule-to their sorrow. It is a very singular habit of some of these fowl when flying high over a gunner, upon his utterance of a shout or a shrill whistle, suddenly to check their onward flight and pitch or drop almost straight down, thus putting themselves in range of the deadly fusillade.

I wish I could adequately describe a scene which I witnessed on the old Pilgrim coast at Manomet one $5^{\text {th }}$ of November. Flying gray clouds covered the sky. The wind was northeast, and increasing every hour. A few boats went out early but soon came in, as the seas were becoming dangerous. Low over the frothing ocean flew lines and clouds of wild-fowl, scudding from the north before the blasts. They were in sight all the time. Before one flock had passed southward, several more were to be seen coming, at times six or eight flocks in sight at once. By ten the rain began to beat spitefully on our faces as we stood on the bluff with 
awed spirits watching Nature in her passion. By noon the wind had reached hurricane force. Flocks of fowl were fairly hurled in over the rocks, many of them to be shot down by the "station" men, and others, who stood ready. I made no effort to estimate the number of that day's flight. Thousands upon thousands there were, and of all kinds. The surf thundered in upon the rocks, and clouds of spray flew up over the top of the bluff. It was a wild, an awful night. Wakeful we lay in our beds that rocked as the avalanches of atmosphere were hurled upon the frail, trembling cottage.

In the morning when I opened the door and stepped out, a blast struck me that made me gasp for breath and cling to the railing. Blinded with the stinging sleet, I could not see whether fowl were flying or not. A neighboring barn had disappeared, lying in fragments on the rocks around the Point. Everything was white with snow. Winter had come upon land, ocean, and wild-fowl.

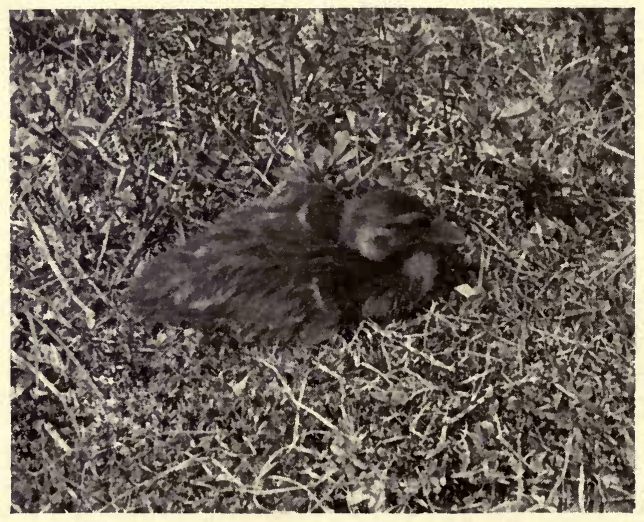

YOUNG DUSKY DUCK, MAGDALEN ISLANDS 



\section{DAY USE}

RETURN TO DESK FROM WHICH BORROWED

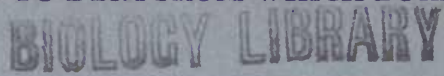

This book is due on the last date stamped below, or on the date to which renewed.

Renewed books are subject to immediate recall.

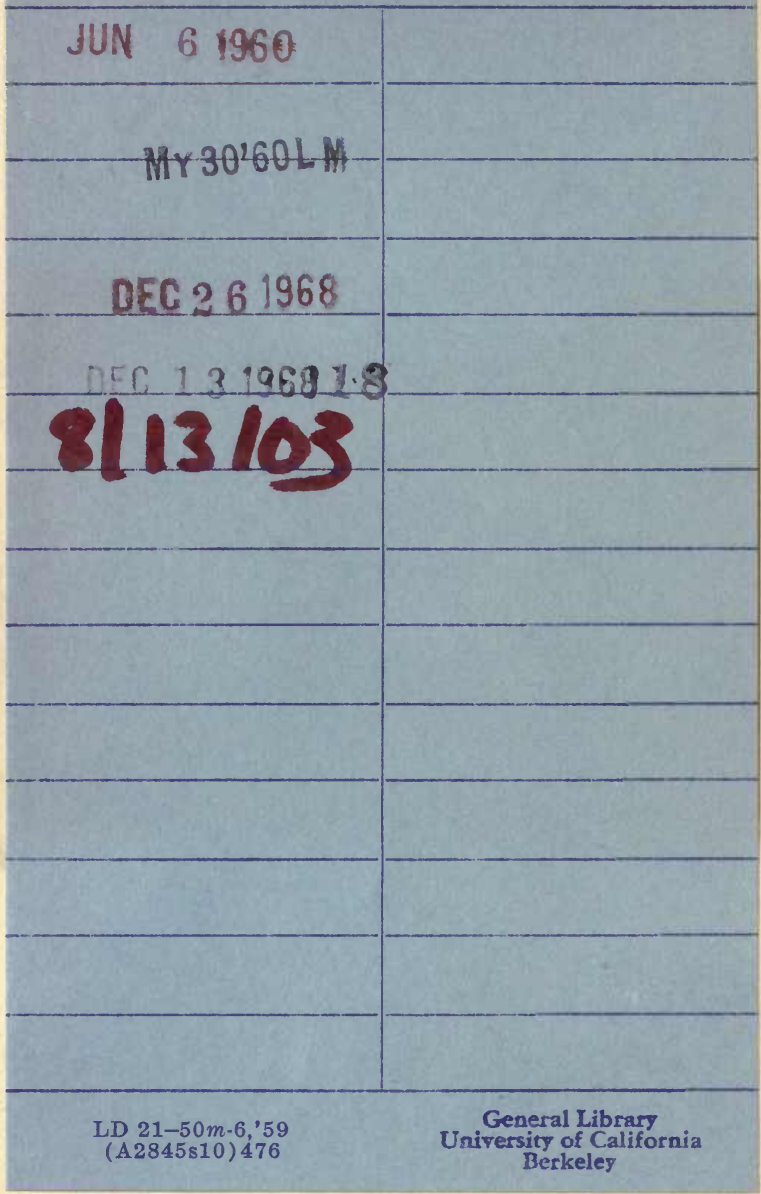




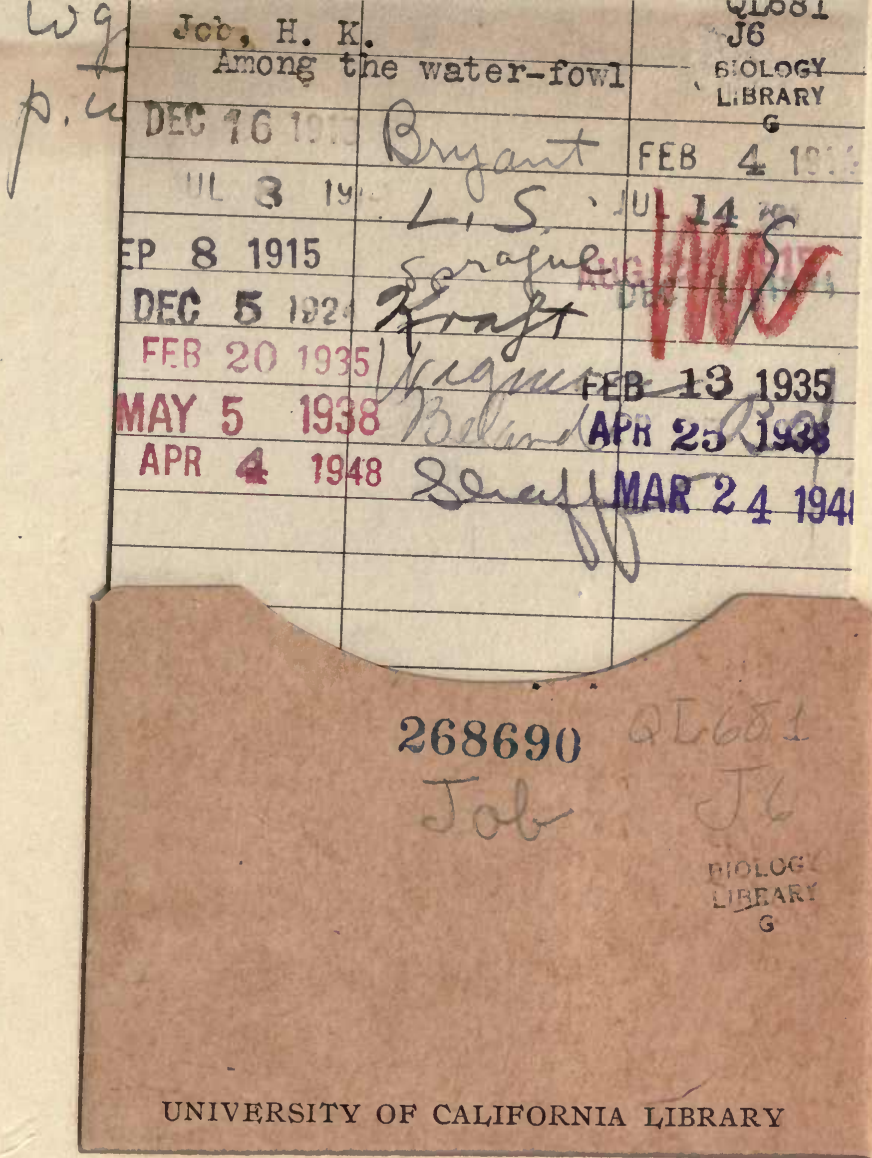




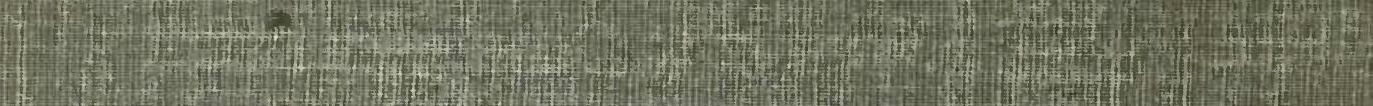
(1) 1 (1) 3. 6.
He

H.

W

(1)

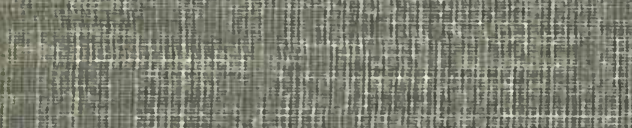

|

13:

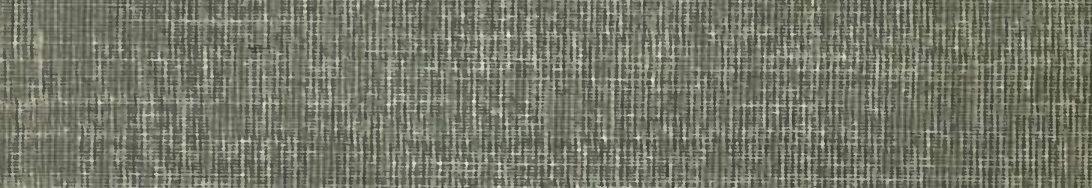

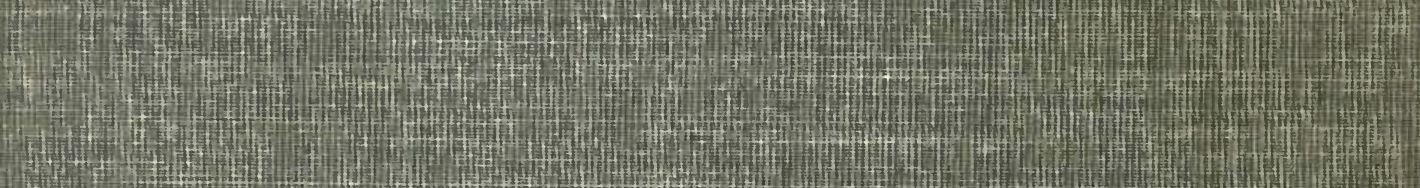
(1) 